\title{
ANÁLISES HISTOLÓGICAS E BIOQUÍMICAS EM CALOS DE Eucalyptus urophylla S.T. Blake CULTIVADOS in vitro SOB INTERAÇÃO NUTRICIONAL DE BORO E CÁLCIO
}

\author{
RAQUEL TREVIZAM
}

Tese apresentada à Escola Superior de Agricultura "Luiz de Queiroz", Universidade de São Paulo, para obtenção do título de Doutor em Recursos Florestais, Área de Concentração: Recursos Florestais, com opção em Silvicultura e Manejo Florestal.

P I R A C I C A B A

Estado de São Paulo - Brasil

Março - 2005 


\title{
ANÁLISES HISTOLÓGICAS E BIOQUÍMICAS EM CALOS DE Eucalyptus urophylla S.T. Blake CULTIVADOS in vitro SOB INTERAÇÃO NUTRICIONAL DE BORO E CÁLCIO
}

\author{
RAQUEL TREVIZAM
}

Bacharel em Ciências Biólogicas

Orientador: Prof. Dr. MARCILIO DE ALMEIDA

Tese apresentada à Escola Superior de Agricultura "Luiz de Queiroz", Universidade de São Paulo, para obtenção do título de Doutor em Recursos Florestais, Área de Concentração: Recursos Florestais, com opção em Silvicultura e Manejo Florestal.

P I R A C I C A B A

Estado de São Paulo - Brasil

Março - 2005 
Dados Internacionais de Catalogação na Publicação (CIP) DIVISÃO DE BIBLIOTECA E DOCUMENTAÇÃO - ESALQ/USP

\section{Trevizam, Raque}

Análises histológicas e bioquímicas em calos de Eucalyptus urophylla S.T. Blake cultivados in vitro sob interação nutricional de boro e cálcio / Raquel Trevizam. - Piracicaba, 2005.

167 p. : il.

Tese (doutorado) - - Escola Superior de Agricultura Luiz de Queiroz, 2005. Bibliografia.

1. Boro 2. Cálcio 3. Cultura de tecido 4. Eletroforese em gel 5. Eucalipto 6. Morfogênese vegetal 7. Morfologia vegetal 8. Proteína I. Título

CDD 634.9734 
"Se especializar pensando somente na utilidade direta das coisas faz com que o espírito morra" 


\section{OFEREÇO}

Aos meus pais, Jacir e Valentina,

Por todo o AMOR e APOIO

Ao meu querido irmão Matheus,

Pela HONESTIDADE

Ao meu amor Fabiano,

Por todo o CARINHO e DEDICAÇÃO

DEDICO

À NATUREZA

Fonte inesgotável de sabedoria 


\section{AGRADECIMENTOS}

À Deus, em todas as suas formas;

Ao Prof. Dr. Marcílio de Almeida pela orientação durante todos estes anos;

Ao Prof. Dr. Antônio Natal Gonçalves pela ajuda preciosa e pelo carinho;

Ao Prof. Dr. Paulo C. Mello, pela amizade;

Ao Prof. Dr. Rogério M. C. Pinto, pela paciência;

Ao Prof. Dr. José L. Gonçalves, pelas palavras sensatas no momento oportuno;

Ao Prof. Dr. Décio Barbin, pela doçura e bondade;

Aos técnicos e amigos José R. Romanini (LAFISA) e Cássia R. F. Figueiredo (Laboratório de Morfogênese e Biologia Reprodutiva), por toda a ajuda;

A todos os funcionários do Departamento de Ciências Florestais, em especial: Margarete A. Z. Pinhese, Catarina Germuts e Evandro Dell"Amatrici;

A todos os funcionários da Biblioteca Central, pela simpatia e disposição. Um abraço especial à Silvia Zinsly e Eliana Garcia;

Aos amigos Edson N. Higashi, Ronaldo L. V. A. Silveira e Marta R. A. Muniz, pelos bons papos, reflexões úteis e principalmente, pelas festanças;

Ao querido amigo Roger Marzochi pela presença afetuosa (SEMPRE !);

Ao meu IRMÃO querido Vanderlei A. Stefanuto, pela grandeza de alma;

A minha família, em especial a Tia Belezinha e Vitor;

Aos fiéis Gordinho, Lupo, Huguinho e a insuperável, Patola. Vocês me ensinam todos os dias e fazem com que eu acredite em um mundo melhor!

A CAPES pela concessão da bolsa.

OBRIGADA! 


\section{SUMÁRIO}

Página

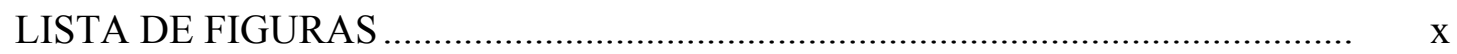

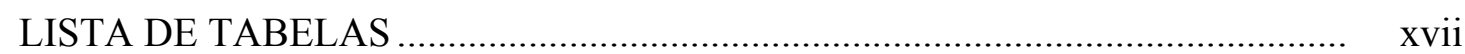

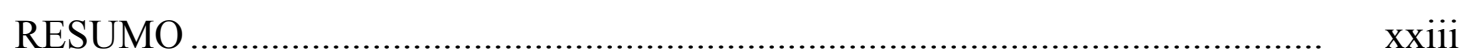

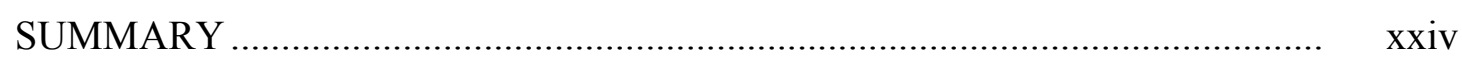

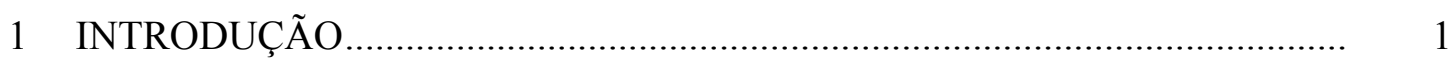

2 REVISÃO DE LITERATURA …............................................................. 4

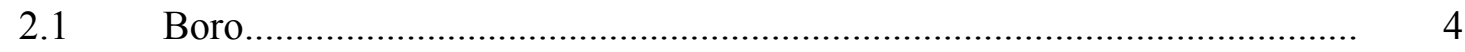

2.1.1 Forma disponível e concentrações adequadas .............................................. 4

2.1.2 Sintomas de deficiência nutricional .......................................................... 5

2.1.3 Sintomas de toxidez nutricional ............................................................... 9

2.1.4 Prováveis funções celulares .......................................................................... 12

2.1.5 Principais atuações celulares ................................................................ 15

2.1.5.1 Parede celular..................................................................................... 15

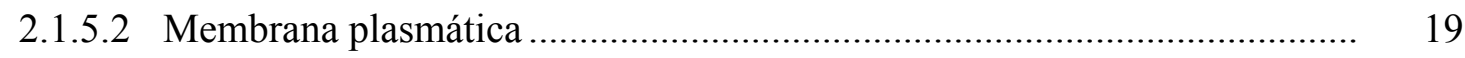

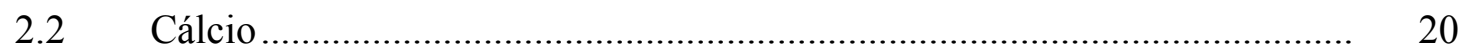

2.2.1 Forma disponível e concentrações adequadas ........................................... 20

2.2.2 Sintomas de deficiência nutricional .............................................................. 21

2.2.3 Sintomas de toxidez nutricional.............................................................. 23

2.2.4 Prováveis funções celulares ....................................................................... 24

2.2.5 Principais atuações celulares ................................................................... 27

2.2.5.1 Parede celular........................................................................................ 27 


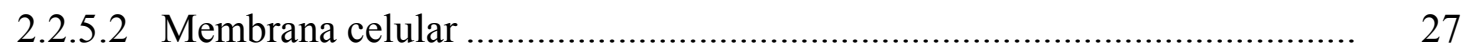

2.3 Interação entre cálcio e boro .......................................................................... 28

$2.4 \quad$ Análises bioquímicas ............................................................................ 29

2.4.1 Aminoácidos e proteínas ..................................................................... 29

2.4.2 Eletroforese de proteínas solúveis totais em gel de poliacrilamida (SDS-PAGE) .............................................................................. 30

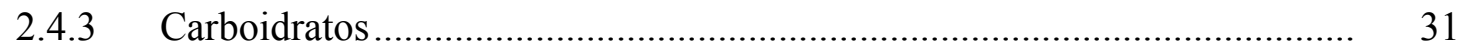

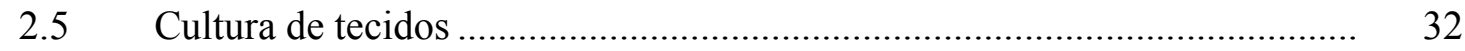

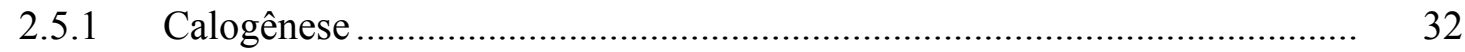

2.5.2 Embriogênese somática ….................................................................... 34

3 MATERIAL E MÉTODOS ........................................................................ 41

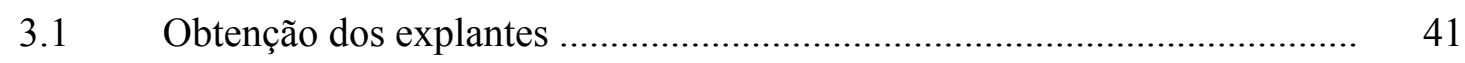

3.2 Avaliação dos tratamentos ........................................................................ 44

3.2.1 Análises morfológicas.............................................................................. 44

3.2.2 Estudos anatômicos .......................................................................... 44

3.2.3 Análises de massa fresca e massa seca..................................................... 45

3.2.4 Análises bioquímicas............................................................................ 45

3.2.4.1 Determinação dos níveis de prolina (modificado de Bates et al.,

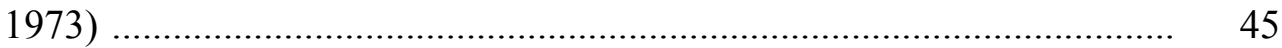

3.2.4.1.1 Determinação com reagente de ninidrina ácida....................................... 46

3.2.4.2 Determinação de carboidratos não-estruturais solúveis totais - Método de Antrona (Yenm \& Willis, 1954) .......................................................... 47

3.2.4.2.1 Extração dos carboidratos não-estruturais solúveis totais......................... 47

3.2.4.2.2 Determinação com reagente de Antrona ................................................. 47

3.2.4.3 Quantificação de proteínas totais (Método de Bradford, 1976) ................ 48

3.2.4.3.1 Extração de proteínas ................................................................................. 48

3.2.4.3.2 Quantificação de proteínas totais.............................................................. 49

3.2.4.4 Eletroforese de proteínas solúveis totais em gel de poliacrilamida (Alfenas et al., 1991) ....................................................... 50 
3.2.4.4.1 Géis para eletroforese …....................................................................... 50

3.2.4.4.2 Procedimento para coloração do gel com prata....................................... 51

3.2.4.5 Análise estatística dos dados................................................................. 53

$4 \quad$ RESULTADOS E DISCUSSÃO …….................................................. 55

$4.1 \quad$ Morfologia externa …...................................................................... 55

4.1.1 Considerações gerais................................................................................. 55

4.1.2 Tamanho dos calos............................................................................. 59

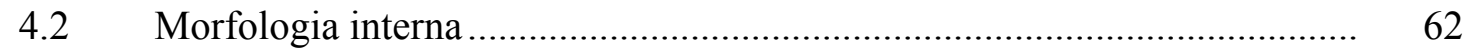

4.2.1 Considerações gerais.......................................................................... 62

4.2.2 Morfologia interna associada a morfologia externa ................................. 69

4.2.2.1 Rizogênese ................................................................................................. 69

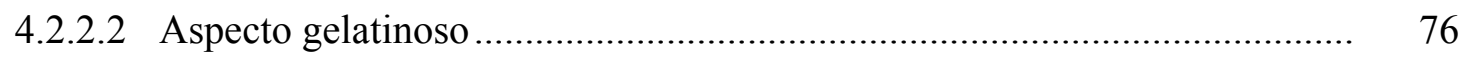

4.2.2.3 Estruturas globulares na superfície dos calos e friabilidade....................... 78

4.2.2.4 Presença de pigmentos e metabólitos secundários ..................................... 82

4.3 Análises quantitativas ............................................................................... 88

4.3.1 Considerações gerais.............................................................................. 88

4.3.2 Avaliação de massa fresca e seca em calos de E. urophylla........................ 92

4.3.2.1 Avaliação de massa fresca em função das concentrações de boro com diferentes concentrações de cálcio aos 21 e 31 dias de cultivo in vitro ...... 92

4.3.2.2 Avaliação de massa fresca em função das concentrações de cálcio com diferentes concentrações de boro aos 21 e 31 dias de cultivo in vitro..........

4.3.2.3 Avaliação de massa seca em função das concentrações de boro com diferentes concentrações de cálcio aos 21 e 31 dias de cultivo in vitro .......

4.3.2.4 Avaliação de massa seca em função das concentrações de cálcio com diferentes concentrações de boro aos 21 e 31 dias de cultivo in vitro......... 105

4.3.3 Avaliação dos teores de prolina ................................................................... 109

4.3.3.1 Avaliação dos teores de prolina em função das concentrações de boro com diferentes concentrações de cálcio aos 21 e 31 dias de cultivo in vitro. 
4.3.3.2 Avaliação dos teores de prolina em função das concentrações de cálcio com diferentes concentrações de boro aos 21 e 31 dias de cultivo in vitro. 114

4.3.4 Avaliação de carboidratos não estruturais solúveis totais .......................... 119

4.3.4.1 Avaliação dos conteúdos de carboidratos não estruturais solúveis totais em função das concentrações de boro com diferentes concentrações de cálcio aos 21 e 31 dias de cultivo in vitro

4.3.4.2 Avaliação dos conteúdos de carboidratos não estruturais solúveis totais em função das concentrações de cálcio com diferentes concentrações de boro aos 21 e 31 dias de cultivo in vitro

4.3.5 Avaliação do conteúdo de proteínas solúveis totais

4.3.5.1 Avaliação dos conteúdos de proteínas solúveis totais em função das concentrações de boro com diferentes concentrações de cálcio aos 21 dias de cultivo in vitro

4.3.5.2 Avaliação dos conteúdos de proteínas solúveis totais em função das concentrações de cálcio com diferentes concentrações de boro aos 21 dias de cultivo in vitro

4.4 Eletroforese de proteínas solúveis totais em gel de poliacrilamida (SDSPAGE).

5 CONCLUSÕES 


\section{LISTA DE FIGURAS}

Página

1 Morfologia externa de calos de E. urophylla cultivados in vitro por 21 dias em meio N7 (Simola, 1985) modificado com concentrações combinadas de boro e cálcio. Os números seguidos de letras (1a-25a) nas linhas de calos representam os tratamentos correspondentes e T26a aponta o tratamento padrão (Tabela 2). As setas verdes indicam a presença de antocianinas. As setas pretas apontam a presença de raízes. As setas azuis mostram a presença de estruturas globulares nas superfícies dos calos. As estrelas cor de laranja na linha representam os tratamentos com oxidação. Barras $=1 \mathrm{~cm}$

2 Detalhes de calos cultivados in vitro por 21 dias em meio N7 modificado com diferentes concentrações de boro e cálcio. A) Calo com presença de raízes ligadas de forma frágil com a estrutura; B) Calo com presença de raízes ligadas de forma coesa a estrutura $\mathbf{C}$ ) Aspecto gelatinoso do calo; D) Estruturas globulares na superfície do calo (setas); E) Calo friável com presença de oxidação; F) Calo com presença de antocianinas. Barras $=1 \mathrm{~cm}$ 
3 Morfologia externa de calos de E. urophylla cultivados in vitro por 31 dias em meio N7 (Simola, 1985) modificado com concentrações combinadas de boro e cálcio. Os números seguidos de letras (1b-25b) nas linhas de calos representam os tratamentos correspondentes e T26b aponta o tratamento padrão (Tabela 2). As setas verdes indicam a presença de antocianinas. As setas pretas apontam a presença de raízes. As setas azuis mostram a presença de estruturas globulares na superfície dos calos. As estrelas cor de laranja na linha representam os tratamentos com oxidação. Barras $=1 \mathrm{~cm}$.

4 Tamanhos médios dos calos (cm) de Eucalyptus urophylla cultivados in vitro em meio N7 modificado com concentrações distintas de boro e cálcio (tratamentos $\mathrm{T} 1$ à T26, Tabela 2) em dois períodos distintos de cultivo ( 21 e 31 dias)

5 Aspecto geral dos meristemóides apresentados aos 21 dias de cultivo in vitro em calos de E. urophylla. As setas indicam a presença de células pequenas organizadas com formatos isodiamétricos e divisões nucleares.

6 Aspecto geral dos meristemóides apresentados aos 31 dias de cultivo in vitro em calos de E. urophylla. A) células de aspecto meristemático com formas alongadas (em detalhe), núcleos proeminentes com indicação de divisão celular (seta branca grande) e diferenciação de sistema vascular (seta branca pequena); B) Detalhe elementos vasculares do xilema (em vista longitudinal) formados isoladamente nos calos (setas brancas) 
$7 \quad$ Aspecto geral de meristemóide com forma circular visualizado aos 31 dias em combinações especificas de boro e cálcio. A) Conformação circular do meristemóide (seta); B) diferenciação do xilema no centro do meristemóide sem diferenciação normal de estruturas radiculares (seta); C) Detalhe dos xilemas (setas brancas pequenas) e dos núcleos proeminentes com presença de divisão celular (seta branca grande)

8 Formação de primórdios radiculares em cortes longitudinais. A) Presença de raízes em início de formação apresentando desenvolvimento endógeno, denotando uma ligação evidente entre raiz e calo; B) Raiz que rompeu as células internas do calo e despontou na superfície sem perder a conexão inicial; C) Raiz desligada da massa de calos

9 Aspecto geral de estruturas radiculares presentes nos tratamentos em combinações específicas de cálcio e boro. A) Raiz com conformação desestruturada, apresentando células mais coradas na endoderme (setas brancas) e ausência de células epidérmicas (seta preta); B) Detalhe da região com espessamento (setas)

10 Estruturas radiculares em corte longitudinal e transversal presente em combinações específicas de boro e cálcio. A) corte longitudinal de raiz apresentando diferenciações celulares; B) Detalhe da região do cilindro vascular apresentando desestruturação e rompimento (seta branca); área mais corada na região da epiderme e córtex (seta preta); C) Corte longitudinal com distinção das partes que compõem a raiz: co - coifa apresentando desestruturação; me - provável região meristemática; cv cilindro vascular; ct -córtex; en - endoderme; ctm - córtex apresentando células modificadas e colapsadas; cvr - cilindro vascular 
com células $\quad$ rompidas; $\quad$ pr $\quad-\quad$ pêlos radiculares

11 Aspecto geral de calos onde foram verificadas características gelatinosas.

A) Processo de desestruturação presente em calos cultivados por 21 dias (setas); B) Detalhe das regiões com desestruturação celular

12 Tipos celulares presentes em calos com aspecto globular. Detalhes: A) células menores e de aspecto meristemático, com relação núcleo/plasmática alta; B) células de tamanhos menores que o tipo anterior denotando aspecto parenquimático a esta região do calo; C) células se desenvolvendo em estratos indicando atividade cambial; D) baixa coesão celular, caracterizando um aspecto frouxo em algumas nas regiões periféricas do calo; E) células de tamanho superior aos demais (seta maior) mescladas com células pequenas semelhantes ao tipo representado em A (seta menor)

13 Aspecto geral da morfologia interna de calos com característica friável. A) Conformação geral das células com aspecto pouco diferenciado. A circunferência delimita um detalhe do calo; B) Detalhe de A, com região apresentando provável processo de diferenciação rizogênica em calos cultivados in vitro por 31 dias

14 Aspecto das áreas oxidadas em calos de E. urophylla cultivados in vitro em períodos distintos com concentrações de boro e cálcio. A) Área de oxidação localizada na periferia dos calos presente em tratamentos cultivados in vitro por 21 dias (seta); B) Presença de áreas oxidadas em calos cultivados por 31 dias, ressaltando áreas periféricas com oxidação 
(setas maiores) e áreas internas com a mesma característica (setas menores)

15 Cortes histológicos de calos de E. urophylla aos 21 dias de cultivo in vitro apresentando granulações intracelulares. A) Visão geral da área do calo; B) Detalhe das estruturas, onde a seta maior aponta a presença de plastos compostos por pigmentos avermelhados e a seta menor mostra a presença de prováveis grãos de amido.

16 Morfologia interna de calos de E. urophylla cultivados in vitro por 21 dias evidenciando estruturas morfogênicas. A) Estrutura pré-globular originada a partir da periferia do calo (seta); B) Presença de meristemóides evidenciando a capacidade de diferenciação celular em tratamentos específicos (seta)

17 Quantidade de massa fresca (gramas) de calos E. urophylla avaliada aos 21 e 31 dias de cultivo in vitro em função de diferentes concentrações de boro em determinadas concentrações de cálcio no meio de cultura.

18 Quantidade de massa fresca (gramas) de calos E. urophylla avaliada aos 21 e 31 dias de cultivo in vitro em função de diferentes concentrações de cálcio em determinadas concentrações de boro no meio de cultura

19 Quantidade de massa seca (miligramas) de calos E. urophylla avaliada aos 21 e 31 dias de cultivo in vitro em função de diferentes concentrações de boro em determinadas concentrações de cálcio no meio de cultura

20 Quantidade de massa seca (miligramas) de calos E. urophylla avaliada aos 21 e 31 dias de cultivo in vitro em função de diferentes 
concentrações de cálcio em determinadas concentrações de boro no meio de cultura

21 Teor de prolina ( $\mu \mathrm{g} / \mathrm{g}$ massa fresca) de calos E. urophylla avaliada aos 21 e 31 dias de cultivo in vitro em função de diferentes concentrações de boro em determinadas concentrações de cálcio no meio de cultura

22 Teor de prolina ( $\mu \mathrm{g} / \mathrm{g}$ massa fresca) de calos E. urophylla avaliada aos 21 e 31 dias de cultivo in vitro em função de diferentes concentrações de cálcio em determinadas concentrações de boro no meio de cultura

23 Quantidade de carboidratos não estruturais solúveis totais (mg / g massa fresca) em calos E. urophylla avaliada aos 21 e 31 dias de cultivo in vitro em função de diferentes concentrações de boro em determinadas concentrações de cálcio no meio de cultura

24 Quantidade de carboidratos não estruturais solúveis totais (mg / g massa fresca) em calos E. urophylla avaliada aos 21 e 31 dias de cultivo in vitro em função de diferentes concentrações de cálcio em determinadas concentrações de boro no meio de cultura.

25 Conteúdo de proteínas solúveis totais (mg / g massa fresca) em calos $E$. urophylla avaliada aos 21 dias de cultivo in vitro em função de diferentes concentrações de boro em determinadas concentrações de cálcio no meio de cultura

26 Conteúdo de proteínas solúveis totais ( $\mathrm{mg} / \mathrm{g}$ massa fresca) em calos $E$. urophylla avaliada aos 21 dias de cultivo in vitro em função de diferentes 
concentrações de cálcio em determinadas concentrações de boro no meio de cultura

27 Gel SDS-PAGE de proteínas solúveis totais de E. urophylla cultivados in vitro, por 21 dias, submetidos a diferentes combinações de boro e cálcio (Tabela 2). As setas indicam diferenças no grau de coloração: AMARELA, indica menor intensidade de coloração; BRANCA, indica maior intensidade de coloração. As linhas pontilhadas em verde determinam a presença de bandas que não apareceram no padrão $(\mathrm{P}) \ldots . . . . .$.

28 Gel SDS-PAGE de proteínas solúveis totais de E. urophylla cultivados in vitro, por 31 dias, submetidos a diferentes combinações de boro e cálcio (Tabela 2). As setas indicam diferenças no grau de coloração. AMARELA: indica menor intensidade de coloração; BRANCA: indica maior intensidade de coloração. As linhas pontilhadas em verde determinam a presença de bandas que não apareceram no padrão $(\mathrm{P})$. A linha rosa indica a presença de uma banda expressa aos 21 dias de cultivo in vitro e ausente na maioria dos tratamentos aos 31 dias de cultivo in vitro. 


\section{LISTA DE TABELAS}

Página

1 Composição do meio N7 (Simola, 1985).

Tratamentos empregados em culturas in vitro de E. urophylla relacionando concentrações de boro e cálcio em períodos distintos

3 Resumo da análise de variância para as características massa fresca $(\mathrm{g})$ e massa seca (mg) avaliadas aos 21 dias de cultivo in vitro para calos de $E$. urophylla

$4 \quad$ Resumo da análise de variância para as características prolina $(\mu \mathrm{g} / \mathrm{g}$ Massa Fresca), carboidratos não estruturais solúveis totais (mg / g Massa Fresca), proteína solúvel total (mg / g Massa Fresca) avaliadas aos 21 dias de cultivo in vitro para calos de $E$. urophylla

5 Resumo da análise de variância para as características massa fresca (g) e massa seca (mg) avaliadas aos 31 dias de cultivo in vitro para calos de $E$. urophylla 
Resumo da análise de variância para as características prolina $(\mu \mathrm{g} / \mathrm{g}$ Massa Fresca), carboidratos não estruturais solúveis totais (mg / g Massa Fresca), proteína solúvel total (mg / g Massa Fresca) avaliadas aos 31 dias de cultivo in vitro para calos de $E$. urophylla

7 Equações de regressão correspondentes às concentrações de boro (B), em $\mu \mathrm{M} . \mathrm{L}^{-1}$, dentro de cada concentração de cálcio $(\mathrm{Ca}), \mathrm{em} \mathrm{mM} \cdot \mathrm{L}^{-1}$, no meio de cultura, para a característica massa fresca (g) de calos de E urophylla avaliada aos 21 dias de cultivo in vitro

8 Equações de regressão correspondentes às concentrações de boro (B), em $\mu \mathrm{M} . \mathrm{L}^{-1}$, dentro de cada concentração de cálcio $(\mathrm{Ca})$, em mM.L ${ }^{-1}$, no meio de cultura, para a característica massa fresca de calos de E. urophylla avaliada aos 31 dias de cultivo in vitro

9 Equações de regressão correspondentes às concentrações de cálcio $(\mathrm{Ca})$, em mM.L ${ }^{-1}$, dentro de cada concentração de boro (B), em $\mu M \cdot L^{-1}$, no meio de cultura, para a característica massa fresca (g) de calos de $E$. urophylla avaliada aos 21 dias de cultivo in vitro. 
10 Equações de regressão correspondentes às concentrações de cálcio $(\mathrm{Ca})$, em mM.L ${ }^{-1}$, dentro de cada concentração de boro (B), em $\mu M \cdot L^{-1}$, no meio de cultura, para a característica massa fresca (g) de calos de $E$. urophylla avaliada aos 31 dias de cultivo in vitro

11 Equações de regressão correspondentes às concentrações de boro (B), em $\mu \mathrm{M} \cdot \mathrm{L}^{-1}$, dentro de cada concentração de cálcio $(\mathrm{Ca})$, em mM.L $\mathrm{L}^{-1}$, no meio de cultura, para a característica massa seca $(\mathrm{mg})$ de calos de E. urophylla avaliada aos 21 dias de cultivo in vitro

12 Equações de regressão correspondentes às concentrações de boro (B), em

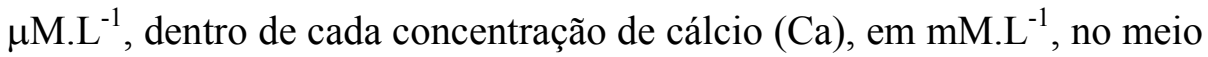
de cultura, para a característica massa seca de calos avaliada aos 31 dias de cultivo in vitro

13 Equações de regressão correspondentes às concentrações de cálcio $(\mathrm{Ca})$, em mM.L ${ }^{-1}$, dentro de cada concentração de boro (B), em $\mu M \cdot L^{-1}$, no meio de cultura, para a característica massa seca $(\mathrm{mg})$ de calos de $E$. urophylla avaliada aos 21 dias de cultivo in vitro 
14 Equações de regressão correspondentes às concentrações de cálcio $(\mathrm{Ca})$, em mM.L ${ }^{-1}$, dentro de cada concentração de boro (B), em $\mu M \cdot L^{-1}$, no meio de cultura, para a característica massa seca $(\mathrm{mg})$ de calos de $E$. urophylla avaliada aos 31 dias de cultivo in vitro

15 Equações de regressão correspondentes às concentrações de boro (B), em $\mu \mathrm{M} \cdot \mathrm{L}^{-1}$, dentro de cada concentração de cálcio $(\mathrm{Ca})$, em mM.L $\mathrm{L}^{-1}$, no meio de cultura, para a característica prolina ( $\mu \mathrm{g} / \mathrm{g}$ de Massa Fresca) em calos de E urophylla avaliada aos 21 dias de cultivo in vitro.

16 Equações de regressão correspondentes às concentrações de boro (B), em $\mu \mathrm{M} . \mathrm{L}^{-1}$, dentro de cada concentração de cálcio $(\mathrm{Ca}), \mathrm{em} \mathrm{mM.L^{-1 }}$, no meio de cultura, para a característica prolina ( $\mu \mathrm{g} / \mathrm{g}$ de Massa Fresca) em calos de E urophylla avaliada aos 31 dias de cultivo in vitro.

17 Equações de regressão correspondentes às concentrações de cálcio $(\mathrm{Ca})$, em mM.L ${ }^{-1}$, dentro de cada concentração de boro (B), em $\mu M \cdot L^{-1}$, no meio de cultura, para a característica prolina ( $\mu \mathrm{g} / \mathrm{g}$ de Massa Fresca) em calos de E. urophylla avaliada aos 21 dias de cultivo in vitro.

18 Equações de regressão correspondentes às concentrações de cálcio $(\mathrm{Ca})$, em mM.L $L^{-1}$, dentro de cada concentração de boro (B), em $\mu \mathrm{M} \cdot \mathrm{L}^{-1}$, no meio de cultura, para a característica prolina ( $\mu \mathrm{g} / \mathrm{g}$ de Massa Fresca) em calos de E. urophylla avaliada aos 31 dias de cultivo in vitro 
19 Equações de regressão correspondentes às concentrações de boro (B), em

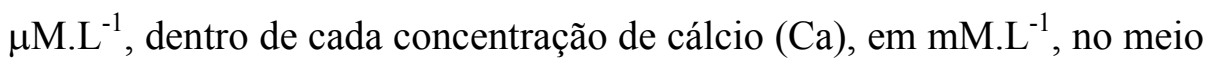
de cultura, para a característica carboidratos não estruturais solúveis totais (mg/g de Massa Fresca) em calos de E. urophylla avaliada aos 21 dias de cultivo in vitro.

20 Equações de regressão correspondentes às concentrações de boro (B), em

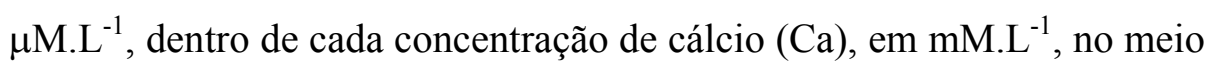
de cultura, para a característica carboidratos não estruturais solúveis totais (mg/g de Massa Fresca) em calos de E urophylla avaliada aos 31 dias de cultivo in vitro.

21 Equações de regressão correspondentes às concentrações de cálcio $(\mathrm{Ca})$, em mM.L ${ }^{-1}$, dentro de cada concentração de boro (B), em $\mu \mathrm{M} \cdot \mathrm{L}^{-1}$, no meio de cultura, para a característica carboidratos não estruturais solúveis totais em calos (mg/g de Massa Fresca) em calos de E urophylla avaliada aos 21 dias de cultivo in vitro

22 Equações de regressão correspondentes às concentrações de cálcio $(\mathrm{Ca})$, em mM.L ${ }^{-1}$, dentro de cada concentração de boro (B), em $\mu M \cdot L^{-1}$, no meio de cultura, para a característica carboidratos não estruturais solúveis totais em calos (mg/g de Massa Fresca) em calos de E urophylla avaliada aos 31 dias de cultivo in vitro. 
23 Equações de regressão correspondentes às concentrações de boro (B), em $\mu \mathrm{M} . \mathrm{L}^{-1}$, dentro de cada concentração de cálcio (Ca), em mM.L ${ }^{-1}$, no meio de cultura, para a característica proteínas (mg / g de Massa Fresca) em calos de E. urophylla avaliada aos 21 dias de cultivo in vitro

24 Equações de regressão correspondentes às concentrações de de cálcio (Ca), em mM.L ${ }^{-1}$, dentro de cada concentração de boro (B), em $\mu M \cdot L^{-1}$, no meio de cultura, para a característica proteínas $(\mathrm{mg} / \mathrm{g}$ de Massa Fresca) em calos de E. urophylla avaliada aos 21 dias de cultivo in vitro... 


\section{ANÁLISES HISTOLÓGICAS E BIOQUÍMICAS EM CALOS DE Eucalyptus urophylla S.T. Blake CULTIVADOS in vitro SOB INTERAÇÃO NUTRICIONAL DE BORO E CÁLCIO}

Autora: RAQUEL TREVIZAM

Orientador: Prof. Dr. MARCILIO DE ALMEIDA

\section{RESUMO}

O boro e o cálcio são nutrientes essenciais para o desenvolvimento das plantas, entretanto existem poucos registros da atuação destes dois nutrientes de forma conjunta em organismos vegetais. Buscando identificar e quantificar as possíveis implicações do micro e macronutriente no desenvolvimento morfogenético de Eucalyptus urophylla, calos foram cultivados in vitro com diferentes concentrações de boro $(0,25,50,100 \mathrm{e}$ $\left.200 \mu \mathrm{M} . \mathrm{L}^{-1}\right)$ e cálcio $\left(0 ; 3,75 ; 7,50 ; 11,25\right.$ e $\left.15 \mathrm{mM} . \mathrm{L}^{-1}\right)$ sendo avaliados posteriormente quanto a morfologia externa, morfologia interna, tamanho, conteúdo de massa fresca e seca e variação das respostas bioquímicas para o teor de prolina, carboidratos não estruturais solúveis totais, proteína solúveis totais e eletroforese em gel de poliacrilamida. De maneira geral, pode-se verificar que nos dois períodos avaliados as concentrações combinadas de boro e cálcio interferiram em aspectos da morfologia interna que ocasionaram respostas diretas em aspectos visuais das estruturas calogênicas. Da mesma forma, os parâmetros bioquímicos avaliados sofreram a ação das interações nutricionais testadas, determinando a importância desta interação em mecanismos metabólicos, celulares e bioquímicos. 


\title{
HISTOLOGICAL AND BIOCHEMICAL ANALYSES ON CALLUSES OF Eucalyptus urophylla S.T. Blake, CULTIVATED in vitro IN NUTRICIONAL INTERACTION OF BORON AND CALCIUM
}

\author{
Author: RAQUEL TREVIZAM
}

Adviser: Prof. Dr. MARCILIO DE ALMEIDA

\section{SUMMARY}

Boron and calcium are essential nutrients in a plant development, but there are few registers of the common action of these two nutrients in a vegetal organisms. In order to identify and to quantify the possible implications of the micro and macronutrient in the morphogenetic development of Eucalyptus urophylla, calluses were cultivated in vitro with different concentrations of boron $\left(0,25,50,100\right.$ and $200 \mu{\left.\mathrm{M} . \mathrm{L}^{-1}\right)}^{-1}$ and calcium $\left(0 ; 3,75 ; 7,50 ; 11,25\right.$ and $\left.15 \mathrm{mM}^{-1}\right)$ and evaluated in relation to external and internal morphology, morphology, size, fresh and oven dry weight, and the variation of biochemical responses to proline, total non-structural soluble carbohydrates, total soluble proteins and eletrophoresys in poliacrilamida gel. In general, it could be verified that in two evaluation periods the combined concentrations of boron and calcium had intervened in aspects of the internal morphology that had caused direct answers in visual impact in visual aspects of the calluses. Similarly, the biochemical parameters evaluated had suffered action from the tested nutritional interactions, determining the importance of this interactions in metabolic, cellular and biochemical mechanisms. 


\section{INTRODUÇÃO}

O gênero eucalyptus possui cerca de 6 milhões de hectares plantados em todo o mundo, sendo que desta parcela cerca de 3,2 milhões de hectares encontram-se no Brasil, associados principalmente a produção de celulose, carvão, chapas e lenha (Evans, 1992).

Nas últimas décadas têm-se verificado expansões constantes em regiões de climas tropicais uma vez que estas regiões apresentam condições térmicas e de luminosidade propicias para o crescimento florestal, contudo as características edáficas e hídricas de diferentes magnitudes mostram-se como limitações comuns nestas áreas (Eldridge et al., 1994). De acordo com Gonçalves (1995), no Brasil a grande maioria das áreas florestadas ocupadas por Eucalyptus e Pinus estão concentradas sobre solos muito intemperizados e lixiviados, portanto, com baixa disponibilidade de nutrientes.

De maneira geral todos os organismos vegetais cultivados (in ou ex vitro), requerem concentrações adequadas de vários elementos minerais para o seu crescimento, e assim que estas concentrações tornam-se desbalanceadas, as espécies sofrem alterações metabólicas em determinada etapa de seu desenvolvimento gerando em resposta a este descontrole, sintomas visuais característicos em órgãos ou tecidos vegetais, gerando perdas na produtividade e na qualidade de produtos agroflorestais.

Em algumas regiões do país, culturas de Eucalyptus mantidas ex vitro apresentam um padrão de crescimento anormal ou retardado dos pontos de crescimento apical, morte do ponteiro terminal, encurtamento de internódios, clorose de folhas velhas, deformação da lâmina foliar, aumento do diâmetro do pecíolo e do caule, troncos tortuosos, fissuras na casca, diminuição na formação de botões florais, atraso no florescimento, desenvolvimento inadequado dos frutos e redução na produção de 
sementes (Marschner, 1995; Gonçalves \& Valeri, 2001) caracterizando sintomas típicos da deficiência por boro, no entanto sintomas de toxidez não são comuns em áreas naturais cultivadas.

Comparativamente, cultivos in vitro de calos de eucaliptos mantidos em meio de cultura modificado com concentraçõess tóxicas ou deficientes de boro, tornaram possível a determinação da ação do íon em processos bioquímicos, histológicos e de desenvolvimento, evidenciando também a sua importância em processos metabólicos (Trevizam, 2001).

De maneira geral, o cálcio também atua no crescimento global $\mathrm{e}$ desenvolvimento das plantas, porém diferentemente do boro suas ações no metabolismo primário são melhores estabelecidas. Arruda (2000) verificou in vitro a ação de concentraçõess tóxicas e deficientes de cálcio em calos de Eucalyptus urophylla e concluiu que este nutriente atua de forma positiva sobre mecanismos bioquímicos expressos em caracteres morfológicos e morfogenéticos da espécie.

Assim, confirmando a importância isolada destes nutrientes para os organismos vegetais e considerando os poucos dados sobre os processos envolvendo a interação e/ou cooperação destes nutrientes no desenvolvimento celular, este trabalho baseou-se nas seguintes hipóteses:

- prováveis efeitos do boro e do cálcio que podem ser determinantes na diferenciação celular, com evidências posteriores em eventos morfogenéticos dentro da espécie estudada;

- possíveis mecanismos bioquímicos envolvidos na interação boro e cálcio, que interferem no funcionamento integral da espécie.

Com base nas hipóteses estabelecidas, o objetivo geral desta tese foi avaliar o efeito da interação de concentrações nutricionais específicas de boro e do cálcio em calos de Eucalyptus urophylla cultivados in vitro em dois períodos distintos de cultivo.

Os objetivos específicos constituíram na avaliação dos tratamentos através de análises morfológicas externas, internas, análises da massa fresca e seca dos calos além de determinações bioquímicas, como a quantificação de proteínas totais, eletroforese em 
gel de poliacrilamida, determinação de carboidratos não estruturais solúveis totais e determinação de níveis de prolina 


\section{REVISÃO DE LITERATURA}

\subsection{Boro}

\subsubsection{Forma disponível e concentrações adequadas}

O boro (B) é um microelemento essencial e segundo Malavolta (1980) possui mobilidade muito baixa dentro dos tecidos vegetais sendo absorvido pelas plantas na forma $\mathrm{H}_{3} \mathrm{BO}_{3}$ (ácido bórico) ou $\mathrm{H}_{2} \mathrm{BO}_{3}{ }^{-}$(borato).

Dentro dos tecidos foliares o boro pode ser encontrado na forma solúvel e insolúvel, porém em cultura de células a sua forma solúvel não é localizada ( $\mathrm{Hu} \&$ Brown, 1994; Matoh et al., 1992). A localização intracelular do boro ocorre essencialmente na parede celular, ocorrendo na forma ligada com uma fração de pectinas, conhecidas como rhamnogalacturonanas-II ou RG-II (Hu \& Brown, 1994; Kobayashi et al., 1996; Ishii \& Matsunaga, 1996).

De maneira geral, as concentrações de boro aceitáveis para um desenvolvimento adequado das espécies vegetais são determinadas entre 20 a 100 ppm do micronutriente em análises de massa seca vegetal (Jones Junior, 1972). No entanto, estas concentrações de boro são dependentes de inúmeras variáveis. Em amostras de folhas de dicotiledôneas, concentrações menores do que 10 ppm/g.massa seca, foram consideradas como deficientes. Em contrapartida, folhas de trigo exibiram sintomas de carência somente com concentraçõess inferiores a $1 \mathrm{mg}$ boro. $\mathrm{Kg}^{-1}$ massa seca.

Em culturas de Eucalyptus grandis, Rocha Filho et al. (1979) comentam que concentrações adequadas para a espécie seriam entre 46 e 100 ppm em relação ao conteúdo de massa seca. Higashi et al. (2000) consideram que a quantidade adequada de boro para clones de Eucalyptus em condições de mini e micro jardins clonais é de 
35-70 mg. $\mathrm{kg}^{-1}$. No entanto, julgam as concentraçõess superiores a $70 \mathrm{mg} \cdot \mathrm{kg}^{-1}$ como tóxicas e inferiores a $20 \mathrm{mg} \cdot \mathrm{kg}^{-1}$ como deficientes para a cultura.

Em capítulos de girassol, Blamey (1976) considera adequada as concentrações entre 34 a 140 mg. $\mathrm{Kg}^{-1}$ de massa seca, uma vez que abaixo do mínimo indicado a cultura apresenta má formação dos capítulos e conseqüentemente apresenta quedas na produtividade e na produção de sementes. As concentrações associadas com a toxidez para esta cultura são também muito variáveis. Alguns autores registraram como tóxicas doses de 925 mg. Kg ${ }^{-1}$ (Bergmann, 1992), 1150 mg. Kg ${ }^{-1}$ (Blamey et al., 1987) e Aitken \& McCallum (1988) registram um decréscimo no crescimento da planta quando utilizaram na solução do solo doses de $176 \mu \mathrm{M}$ de boro. Trevizam (2001) ao analisar calos de Eucalyptus urophylla in vitro, observou que a concentração com $50 \mu \mathrm{M}$ de boro possibilitou um melhor desenvolvimento das estruturas calogênicas em relação às demais concentrações testadas e concluiu que para os parâmetros analisados e a espécie estudada esta concentração apresentou-se como ideal (padrão).

É sabido que o limite entre os níveis tóxicos e deficientes nas espécies agricultáveis são muito estreitos. Em trabalhos desenvolvidos com a cultura de framboesa (Fragaria ananassa Duch.), diversos autores relatam a existência deste limite (Haydon, 1981; Williams \& Gostick, 1981), porém Bisko et al. (1997) relatam que para culturas in vitro os efeitos causados pela toxidez de boro ainda não foram conclusivos e apenas afirmam que as plantas de framboesa toleraram o aumento dos níveis deste micronutriente no meio de cultura.

\subsubsection{Sintomas de deficiência nutricional}

A deficiência por boro pode exibir uma grande variedade de sintomas, dependendo da espécie e da idade da planta (Taiz \& Zeiger, 1998).

Matoh et al. (1992) afirmam que estes sintomas de carência são uma conseqüência secundária das deficiências causadas pelo boro em espécies vegetais. Dados apresentados pela literatura afirmam que as mudanças morfológicas e físicas causadas por este tipo de deficiência nutricional são provavelmente relacionadas com a 
formação de complexos entre boro e compostos contendo grupos cis-hidroxil (diols) e odifenóis (Dugger, 1983; Römheld \& Marschner, 1991; Shelp, 1993; Marschner, 1995).

De acordo com Taiz \& Zeiger (1998) a deficiência por boro pode ser notada quando: existe a necrose do broto terminal e de folhas jovens, com início do dano na base da lâmina foliar; os caules podem ficar duros e quebradiços; a dominância apical pode ser perdida, causando uma grande quantidade de brotações laterais, no entanto os ápices destas brotações ficam necrosados devido à inibição da divisão celular; os frutos, raízes e tubérculos podem exibir necroses ou anormalidades relacionadas a desestruturações internas dos tecidos.

A forma dos sintomas e sua distribuição nas plantas são atribuídas em muitas espécies à imobilidade do elemento no floema (Gupta, 1993). No entanto, sintomas da deficiência por boro são observadas também em espécies capazes de translocar o microelemento pelo floema, como Prunus, Malus, Pyrus (Brown \& Hu, 1996). Provavelmente isto é uma decorrência da função primária do boro junto a parede celular, fato que influenciaria o desenvolvimento das partes reprodutivas e vegetativas destes gêneros e que independeria de sua translocação (Brown \& Shelp, 1997).

Mengel \& Kirkby (1987) e Marschner (1995), descreveram os sintomas de deficiência de boro e observaram o encurtamento de internódios, clorose de folhas velhas, deformação da lâmina foliar, aumento do diâmetro do pecíolo e do caule, diminuição na formação do botão floral, de flores e do desenvolvimento do fruto.

Hu \& Brown (1994) verificaram também que o tamanho das células foi menor em plantas cultivadas sem boro. Estes dados foram confirmados por Trevizam (2001) que ao analisar calos de E. urophylla registrou um menor tamanho para células cultivadas sem o micronutriente.

Alguns trabalhos têm mostrado que a razão de alongamento das folhas decresce em resposta ao decréscimo ou a interrupção do suprimento externo de boro (Bell et al., 1990; Hu \& Brown, 1994; Huang et al., 1996). Confirmando estas afirmações, Higashi (1996) ao estudar três híbridos de Eucalyptus spp. em culturas in vitro, observou 
que a deficiência visual de boro apresentou como sintomas mais comuns à redução da área foliar, deformação das folhas e clorose das nervuras.

Embora não exista evidência da participação direta do boro na fotossíntese, esta diminuição da lâmina foliar poderia interferir no processo em decorrência da supressão da área fotossintética. Sharma \& Ramchandra (1990) relatam em plantas cultivadas sem o micronutriente uma diminuição do número de estômatos com aberturas reduzidas. Este fato resultaria em um decréscimo na condução do $\mathrm{CO}_{2}$. Os autores relatam também a diminuição da clorofila e proteínas solúveis foliares que atuaria nas reações de Hill e na rede fotossintética.

Embora os sintomas decorrentes da deficiência por boro sejam diversos, muitos autores concordam que o crescimento anormal da planta e o retardamento no crescimento da região apical são comuns na maioria das espécies estudadas (Pilbean \& Kirkby, 1983; Mengel \& Kirkby, 1987; Silveira et al., 1995a; Hu \& Brown, 1997; Trevizam, 2001).

Em condições de campo, a deficiência por boro é extremamente comum e as aplicações deste micronutriente são essenciais para o desenvolvimento das espécies de Eucalyptus (Cannon, 1981; Stape, 1992; Barros et al., 1992; Fonseca et al., 1993; Silveira et al., 1995b).

Sgarbi et al. (1999) ao determinarem o crescimento de um clone híbrido de Eucalyptus grandis X Eucalyptus urophylla em soluções nutritivas com omissão de boro, verificaram reduções no diâmetro, na produção de matéria seca e no crescimento das plantas. Nas espécies E. saligna e E. citriodora, a morte generalizada dos ponteiros também foi evidenciada por Tokeshi et al. (1976) e Carvalho et al. (1980), evidenciando um retardo no crescimento em decorrência da ação do boro nestas áreas meristemáticas. Rocha Filho et al. (1978) ao compararem mudas de E. urophylla cultivadas sem boro em um meio completo notaram uma redução de $61 \%$ na produção da matéria seca para as mudas carentes deste micronutriente. Resultados semelhantes foram obtidos por Rocha Filho et al. (1979) e Silveira (1996). 
Diversos trabalhos, apontam que a resposta mais rápida para a ausência ou deficiência do micronutriente é verificada em raízes. Nestes órgãos, a presença inadequada do micronutriente é responsável pela inibição do crescimento ou não promoção do alongamento (Dugger, 1983; Shelp, 1993; Marschner, 1995). A deficiência de boro parece prejudicar o crescimento das células e a divisão das regiões meristemáticas das raízes, resultando na total inibição do alongamento da raiz. De acordo com Loomis \& Durst (1992), esta inibição pode ser causada por efeitos adversos do boro na estrutura da parede e nos processos de divisão celular.

Da mesma forma que o crescimento vegetativo, o crescimento reprodutivo de muitas plantas é também afetado, sendo que muitas vezes estes sintomas não são claramente notados (Mozafar, 1993). No campo, é comum a observação de plantas sem os sintomas de deficiência, no entanto quando o crescimento reprodutivo se inicia uma grande variedade de sintomas de carência se apresentam incluindo: anomalia de botões florais e flores (Bell et al.,1990a), flores masculinas estéreis (Rerkasen \& Loneragan, 1994); abortos de frutos ou vagens (Rerkasen et al., 1988); vagens com tamanho e número reduzido de sementes (Bergmann, 1992; Keerati-Kasikorn et al., 1993); frutos lesionados de baixa qualidade e com necrose interna (Ram et al., 1989).

Pilbean \& Kirkby (1983) observaram também que esta carência foi responsável pela interrupção do crescimento do tubo polínico.

Anormalidades estruturais também são causadas pela deficiência de boro, especialmente na parede celular (Matoh, 1997). Em culturas de abóbora (Curcubita pepo) e girassol (Helyanthus sp.), a falta de boro resultou em uma rápida inibição do crescimento da raiz e brotos meristemáticos, caracterizando a requisição primária do elemento no crescimento da célula (Loomis \& Durst, 1992). Em folhas de tomateiro (Lycopersicum esculentum), Yamauchi et al. (1986) determinaram que a deficiência de boro afeta a estrutura e composição da parede celular, influenciando na manutenção da associação com cálcio-pectinas.

Segundo Parr \& Longhman (1983), além da interferência estrutural outras desordens metabólicas podem ser apontadas como conseqüência da deficiência de boro, 
são exemplos: a redução no transporte de açúcar, diminuição da lignificação, danos à síntese e estrutura da parede celular, decréscimo no metabolismo de carboidratos, diminuição da síntese de RNA, queda nas taxas respiratórias e ainda a diminuição do metabolismo do ascorbato (Lukaszewski \& Blevins, 1996). Lovatt (1985) indica que reações enzimáticas são alteradas e Pilbean \& Kirkby (1983) sugerem o envolvimento do íon na estabilização da membrana plasmática, sendo muitos sintomas destas deficiências efeitos secundários causados por mudanças na permeabilidade da membrana. Porém, tanto a deficiência como a toxidez do micronutriente, causam anomalias nos vegetais.

\subsubsection{Sintomas de toxidez nutricional}

Existe um pequeno limite que separa os níveis de toxidez e deficiência de boro em plantas (Marschner, 1995). Sintomas de carência são facilmente visualizados, ao passo que os de toxidez não são bem determinados (Rocha Filho et al., 1979).

Em culturas de girassol (Helianthus annuus L.) cultivadas em solução nutritiva, o sintoma inicial inclui uma leve clorose ao longo da margem das folhas, seguido por um escurecimento e manchas de necrose ao longo das margens e entre as nervuras principais do limbo foliar (Blamey et al., 1987). Estes sintomas aparecem nas folhas mais novas e seguem para as mais velhas aumentando a severidade do dano. As áreas necróticas são referidas como os locais de maior acúmulo de boro (Scott, 1960).

A toxidez por boro causa um limitado crescimento dos vegetais em solos áridos e semi-áridos ao redor do mundo. Altas concentrações no solo resultaram, segundo Cartwright et al. (1984), em uma queda significativa (17\%) na produção de grãos de cevada em distritos do sudoeste da Austrália. No Brasil, devido a morfogênese dos solos não são relatados problemas com a toxidez por boro, exceto quando existe um manejo inadequado das áreas agro-florestais plantadas, como o desbalanço nutricional causado por fertilizantes contendo boro ou o uso contínuo e inadequado de irrigação (Bradford, 1966). 
Altas concentrações de boro podem ocorrer naturalmente no solo, na solução do solo, por adição de fertilizantes ou por irrigação, no entanto em ambientes naturais existem poucas áreas com excesso do micronutriente comparando-se com os solos deficientes (Nable et al., 1997). Ainda de acordo com os autores, os maiores depósitos de $\mathrm{B}_{2} \mathrm{O}_{2}{ }^{-7}$ encontram-se na Califórnia. Estas altas concentrações no solo são decorrentes de evaporação marinha e da concentração de sedimentos marinhos argilosos.

No Brasil, a toxidez por boro é comum apenas em viveiros e mini-jardins clonais. Segundo Silveira et al. (2001), estes sintomas são causados por descuidos no preparo de soluções nutritivas e em casos extremos as mini-touças podem chegar a total mortalidade.

Entre as espécies vegetais, um sintoma típico da toxidez por boro caracteriza-se pela queima de folhas com presença de áreas cloróticas ou necróticas, muitas vezes em margens e pontas de folhas velhas, porém este não é um sintoma comum a todas as espécies (Marschner, 1995).

Rocha Filho et al. (1979), estudando os efeitos do boro nas folhas de mudas de Eucalyptus grandis, descreveram que o excesso do micronutriente em soluções nutritivas causou clorose na região internerval de folhas jovens, sendo este sintoma menos intenso em folhas maduras.

A queima de folhas não é um sintoma visível em todas as espécies. Em espécies nas quais o boro é móvel (Malus, Prunus e Pyrus), os sintomas são percebidos em frutos (necrose interna), em nozes (tornam-se viscosas) e na casca (necrose), sendo também perceptíveis a morte do tecido cambial e quebra dos ramos e caules (Hu et al., 1996).

Lovatt \& Bates (1984) relatam que na cultura de abóbora (Curcubita pepo) o efeito da toxidez por boro nas folhas foi refletido no decréscimo da concentração de clorofila, com posterior redução do crescimento, decréscimo da área foliar e queda na fixação de $\mathrm{CO}_{2}$.

Para muitas espécies, não são observados os efeitos visuais de toxidez nas raízes. Comparado com as folhas, os níveis de boro nos tecidos radiculares permanecem menores (Oertli \& Roth, 1969). De acordo com o trabalho desenvolvido por Rocha Filho 
et al. (1979) verificou-se em mudas de E. grandis diferenciações estruturais da raiz. Os autores observaram para esta espécie, uma redução sensível do sistema radicular sob doses tóxicas de boro.

Em folhas de soja mantidas sob altas concentrações do micronutriente, pode ocorrer inibição do metabolismo dos ureídeos (Lukaszewski et al., 1992) e a complexação de ribonucleotídeos, que também são responsáveis por distúrbios metabólicos (Loomis \& Durst, 1992). O encurvamento das folhas, em algumas espécies é um sintoma visível da toxidez, sugerindo a inibição da parede celular, através de distúrbios de ligações presentes na parede celular (Loomis \& Durst, 1992).

Em solos com altas concentrações de boro, a revegetação com espécies tolerantes pode ser uma solução (Banuelo et al., 1993).

Estudos têm demonstrado uma grande variação genética em resposta a altas concentrações de boro. Verificou-se algumas diferenças tanto em níveis inter e intraespecíficos, contudo são relatadas maiores variações em níveis interespecíficos (Nable et al., 1997). As tolerâncias de plantas, a altas concentrações de boro não aparecem apenas em sua totalidade, existe uma atuação ao nível de órgãos e células. Em experimentos realizados com raízes, no campo e em casa de vegetação, os genótipos classificados como susceptíveis produziram estruturas axiais mais curtas, uma menor quantidade de raízes laterais e menos calos do que os genótipos tolerantes a altas concentrações de boro (Huang \& Graham, 1990).

De acordo com Nable et al. (1997), esta tolerância é controlada parcialmente por genes nucleares dominantes. Em cereais este gene tem sido localizado no cromossomo 4A e cromossomos homólogos do grupo 7. Os métodos utilizados para se identificar estes genes são: substituição intra-específica, linhas de adição e análises monossômicas (Paull et al., 1995). Cromossomos homólogos do grupo 5, também têm mostrado um efeito significativo na resposta a altas concentrações do boro em cereais (Manyowa \& Miller, 1991).

Muitos genótipos tolerantes a altas doses deste micronutriente são capazes de manter baixas concentrações do nutriente em brotos, em comparação com os genótipos 
susceptíveis. Desta forma, acredita-se que em diversas espécies de plantas tolerantes exista um mecanismo capaz de excluir os excessos deste nutriente (Nable, 1988). De acordo com Nable et al. (1990) as diferentes habilidades do transporte do boro através de transporte passivo parecem estar associadas com os diferenciais de tolerância à toxidez por este micronutriente. Desta forma, a estrutura da molécula do acido bórico indica uma alta permeabilidade que de forma eficiente encurta a rota e ativa o mecanismo regulatório de absorção em meios de alta concentração (Raven, 1980). Assim, acredita-se que sob condições de potenciais tóxicos, a absorção do boro em raízes parece ser governada pelo transporte passivo (Nable et al., 1997). Estas afirmações são confirmadas por alguns estudos com cevada (Nable et al., 1990), girassol, abóbora e células de tabaco, que mostraram um acúmulo linear de boro com aumento das concentrações externas do micronutriente (Brown \& Hu, 1994).

\subsubsection{Prováveis funções celulares}

Os estudos do papel do boro na nutrição e fisiologia de plantas iniciaram-se na década de 20 com Warington (Hu \& Brown, 1994; Bonilla et al., 1995; Matoh, 1997), entretanto o conhecimento de sua função exata no metabolismo das plantas não foi bem definido até os dias atuais (Teasdale \& Richards, 1990; Matoh et al., 1992; Bonilla et al. 1995; Matoh et al., 1996; Bonilla et al., 1997).

Especula-se que algumas das prováveis implicações do boro na célula vegetal sejam: divisão celular, aumento no tamanho das células, transporte de carboidratos da folha para outros órgãos (Malavolta, 1980) e atuação como agente morfogenético (Spurr, 1957). Sua participação no desenvolvimento da parede celular é muito importante influenciando suas propriedades físicas, ultraestruturais e diferenciação (Yamauchi et al., 1986; Teasdale \& Richards, 1990; Matoh et al., 1992; Hu \& Brown, 1994).

Diversos estudos têm sugerido que o boro atua na biogênese da parede celular das plantas. A existência de um provável envolvimento do elemento na constituição de unidades estruturais básicas da parede celular foi destacada por Teasdale \& 
Richards (1990). Evidências apresentadas por Hu \& Brown (1994) mostraram que o boro esta fisicamente localizado e é estruturalmente importante para a parede celular, suportando a hipótese proposta por Skok (1957), de que o boro está envolvido na formação de unidades estruturais ou "building blocks" da parede celular mais do que em reações metabólicas denotando um estreito relacionamento do íon com mecanismos de crescimento e desenvolvimento do corpo vegetal.

Alguns autores discordam quanto as funções primárias do micronutriente. Lewis (1980), acredita que o boro esteja envolvido na biossíntese de lignina e diferenciação do xilema. De acordo com Shelp (1993) o boro possui uma habilidade particular para formar ligações estáveis com compostos contendo grupos cis-hidroxil (cis-diol). Diversos compostos possuem grupos cis-diol facilitando a formação de boratocomplexos, como os açúcares e seus derivados (açúcar-álcool e ácido urônico) e muitos o-difenólicos (ácido cafeíco e ácido hidroxiferrúlico). A parede celular é rica em compostos cis-diol o que comprova a grande presença de boro nestas estrutura ( $\mathrm{Hu} \&$ Brown, 1994; Matoh et al., 1992). A formação de complexos com alguns fenóis (por exemplo, ácido cafeíco) podem alterar a reunião destes nos tecidos (Cakmak \& Römheld, 1997). De acordo com Pilbean \& Kirkby (1983), a ligação do boro aos blocos de ácido cafeico levam a formação de quinonas, o que facilita a síntese de álcool-fenol que são os precursores da biossíntese da lignina.

O acúmulo de fenóis em tecidos que apresentam deficiência por boro, podem causar um sério prejuízo as funções celulares. Muitos fenóis são conhecidos como fitotóxicos a raízes e brotos, mesmo quando aparecem em baixas concentrações (Vaughan \& Ord, 1990). Desta forma, o acúmulo de fenóis pode aumentar a ativação de enzimas que se utilizam deste composto como substrato aumentando a produção de quinonas. As quinonas são responsáveis pela produção do oxigênio tóxico (ou peróxido de hidrogênio, $\mathrm{H}_{2} \mathrm{O}_{2}$ ). Este acúmulo substancial de quinonas em tecidos deficientes em boro, tem sido considerado como a maior causa dos danos celulares e a interrupção no crescimento (Lee \& Aronof, 1967; Shkol'nik et al., 1981). 
Em extratos de folhas de girassol deficientes em boro, determinou-se a atividade da polifenoloxidase (PPO) e foi verificada que suas concentrações aumentavam à medida que a severidade dos sintomas cresciam (Marschner, 1995).

Assim como os fenóis, a concentração de auxinas pode ser maior em plantas deficientes. Altas concentrações de AIA (ácido indol-acético) nestas plantas foram atribuídas a inibição da AIA-oxidase devido ao acúmulo de compostos fenólicos (Coke \& Whittington, 1968; Bisko et al., 1997). Em contrapartida, verificou-se que os níveis de AIA não diferem em plantas deficientes e tratadas com doses suficientes de boro (Hirsch et al., 1982; Fackler et al., 1985) sugerindo então que os sintomas não se relacionam com excesso de AIA nos tecidos e sim com o acúmulo de fenol-oxidase (Smirnov et al., 1977).

As concentrações de ácido ascórbico foram substancialmente diminuídas, em pontas de raízes de abóbora, em resposta a carência por boro (Lukaszewski \& Blevins, 1996). De acordo com Cordoba-Pedregosa et al. (1996) o ácido ascórbico estaria envolvido na regulação das atividades meristemáticas e na promoção do crescimento. Desta forma a inibição do crescimento dos brotos e das pontas de raízes causadas pela deficiência de boro poderia ser explicada pelo consumo induzido e a restrita biossíntese do referido ácido.

A atividade da glutationa redutase também é afetada pela supressão do boro em meios de cultivo (Foyer et al., 1994). Esta enzima é essencial para a manutenção de altas concentrações de glutationa que está diretamente envolvida na desintoxicação da célula pelo peróxido de hidrogênio $\left(\mathrm{H}_{2} \mathrm{O}_{2}\right)$. Este decréscimo nos níveis da glutationa redutase pode ser crítico porque ela pode sensibilizar as células boro-deficientes, aos danos causados pela produção de quinonas e oxigênios tóxicos $-\mathrm{H}_{2} \mathrm{O}_{2}$, peróxido de hidrogênio (Foyer et al., 1994).

Outra enzima afetada pela carência pelos níveis de boro é a nitrogenase. Sob condições de deficiência por boro, leguminosas diminuem a sua capacidade de fixação do nitrogênio e o peso dos nódulos bacteriano é diminuído. Em raízes de ervilhas, estes sintomas são atribuídos a degeneração da parede e da membrana 
celular (Bolaños et al., 1993) ao passo que em cianobactérias (Anabaena), a atividade da enzima foi marcadamente reduzida após duas horas da retirada do boro do meio de cultura enquanto outros processos metabólicos permaneceram inalterados (GarciaGonzáles et al., 1990). Este fenômeno em bactérias não é bem determinado. Acredita-se que o micronutriente seja requerido para a integridade estrutural dos envelopes dos heterocistos que interagem com os grupos - $\mathrm{OH}$ dos glicolipídeos e camadas de polissacarídeos que são as principais barreiras de difusão do oxigênio do heterocisto (Garcia-Gonzáles et al., 1991).

O decréscimo nos níveis de ácido ascórbico em decorrência da deficiência por boro, pode apresentar conseqüências negativas na atividade da nitrogenase (Foyer et al., 1994).

\subsubsection{Principais atuações celulares}

\subsubsection{Parede celular}

A principal localização do boro é verificada essencialmente na parede celular, ocorrendo na forma ligada com uma fração de pectinas, conhecidas como rhamnogalacturonanas-II (RG-II) (Hu \& Brown, 1994; Kobayashi et al., 1996; Ishii \& Matsunaga, 1996).

Esta função estrutural do boro explica as observações bem conhecidas de que o boro não é reutilizável e pode ser suplementado constantemente durante o crescimento da planta (Skok, 1957).

Alguns estudos sugerem a atuação do boro na biogênese da parede celular. De acordo com Teasdale \& Richards (1990), existe um provável envolvimento do elemento na constituição de unidades estruturais básicas da parede celular, o que denotaria um estreito relacionamento do íon com mecanismos de crescimento e desenvolvimento do corpo vegetal, assim em situações de deficiência mineral observa-se a inibição rápida do crescimento da planta (Hu \& Brown, 1997). 
Em cultura de células de tabaco (Nicotiana tabacum) e abóbora (Curcubita реро), foram detectadas quantidades superiores a $90 \%$ do elemento na parede celular (Matoh et al., 1992; Hu \& Brown, 1994; Nguyen et al., 1995), caracterizando a sua localização intracelular. Segundo Matoh et al. (1992), o elemento é encontrado em quantidades muito pequenas no simplasto.

A maioria do boro da parede celular (mais de 70\%) encontra-se associada com pectinas (Hu \& Brown, 1994; Matoh et al., 1993). É amplamente aceito que as pectinas têm um papel chave na determinação da extensibilidade plástica da parede celular dos vegetais e sob deficiência de boro as propriedades físicas da parede celular são notavelmente alteradas, correlacionando com a rápida expansão da célula $(\mathrm{Hu} \&$ Brown, 1994).

Pectinas são polissacarídeos ácidos ramificados complexos que encontram-se localizados em toda a matriz da parede celular de plantas. A estrutura das pectinas na parede celular tem sido descrita como blocos onde existem regiões lisas e lanosas (de Vries et al., 1982). As regiões de pectinas lisas consistem de homogalacturananas (McNeil et al., 1984) e as regiões lanosas consistem de rhamnogalacturonanas-I (RG-I), rhamnogalacturonanas-II (RG-II), xylogalacturonanos e RG com arabinanos (Arland Junior et al., 1996).

Os polissacarídeos pécticos são um grupo rico em ácido galacturônico, rhamnose, arabinose e galactose. Eles são característicos da lamela média e da parede celular primária de plantas dicotiledôneas sendo menos freqüentes em monocotiledôneas (Brett \& Waldron, 1996).

As RG-II são um mega oligossacarídeo péctico que estão relacionadas com a estrutura primária da parede celular de plantas superiores apresentando a mesma estrutura em todas as espécies de plantas das quais ela tenha sido isolada (Mazeau \& Pérez, 1998). Registros recentes têm mostrado que este mega oligossacarídeo péctico é um grande candidato a complexação do borato de modo que o boro pode se ligar na parede celular através das RG-II. Como o boro é um microelemento essencial às plantas, 
Mazeau \& Pérez (1998), sugerem uma óbvia importância biológica das RG-II na complexação do microelemento dentro da parede celular de vegetais.

Em cultura de células em suspensão de dicotiledôneas, as RG-II são os menores componentes de paredes primárias. Quando isoladas, elas apresentam um grau de polimerização de cerca de 60 , e possuem uma estrutura complexa a qual inclui ácido galacturônico, rhamnose, arabinose e galactose na razão de 10:7:5:5 junto com pequenas quantidades de alguns açúcares raros como o ácido acérico, apiose e ácido 3-deoxymanno-octulosônico (KDO) (Arland Junior et al., 1996), metil-fucose e metil xilose (Brett \& Waldron, 1996).

Loomis \& Durst (1992), propuseram que ésteres de borato com apiose (complexos presentes preferivelmente em RG II) são os responsáveis por ligações cruzadas de polímeros da parede celular e desta forma tornam-se extremamente necessários para a estabilidade da parede celular. As ligações com estas pectinas também denotam certa extensibilidade plástica à parede celular e, sob condições de deficiência, a expansão celular fica inibida (Yamauchi et al., 1986; Matoh et al., 1993; Hu \& Brown, 1994).

Kobayashi et al. (1996) determinaram através de métodos calorimétricos e GLC (cromatografia gás-líquido) a composição de complexos boro-polissacarídeo (BPC) em paredes celulares de rabanete (Raphanus sativus). Os autores observaram que o BPC é composto de 3\% de 2-O-methylfucose, 8\% de Rhamnose, 2\% de Fucose, 4\% de 2-Ometilxilose, $1 \%$ ácido acérico, $7 \%$ de arabinose, $12 \%$ de apiose, $7 \%$ de galactose, $5 \% 2$ keto-3-deoxi-açúcares (Kdo) e 51\% de ácido galacturônico.

O papel do complexo boro-pectina na formação da parede celular fornece uma explicação para a diferenciação de tecidos que precisam de boro em plantas superiores (Loomis \& Durst, 1992). Em paredes celulares primárias de gramíneas, existem pequenas quantidades de pectinas (Darvill et al., 1980) as quais também possuem uma pequena exigência de boro (3-10 $\mu \mathrm{g} . \mathrm{B} \mathrm{g}^{-1}$ de peso seco, Jones Junior et al., 1991). As paredes celulares primárias de dicotiledôneas são caracterizadas pelo alto conteúdo de 
polissacarídeos pécticos (Darvill, 1980) e necessitam de um suprimento de boro muito maior do que em gramíneas (20-30 $\mu \mathrm{g} . \mathrm{B} \mathrm{g}^{-1}$ de peso seco) (Jones Junior et al., 1991).

Yamauchi (1971), registrou a relação entre pectina da parede celular e concentração de boro nos tecidos encontrando uma correlação positiva entre boro insolúvel em água e protopectinas contidas em 33 espécies de plantas.

A formação de complexos de boro insolúvel esta associada com a deficiência do micronutriente em um grande número de espécies. Hu \& Brown (1994) e Matoh et al. (1993) indicaram que a maior parte de boro insolúveis em plantas estão na forma de complexos boro-pectinas.

$\mathrm{Hu}$ et al. (1996), ao testarem 14 espécies com diferentes exigências de boro observaram que há uma diferença significativa na resposta das espécies quando privadas de boro. Também observaram que existe uma correlação positiva entre o conteúdo de boro existente nos tecidos e a quantidade de ácido urônico presente na parede celular. Quando o microelemento foi omitido do meio de cultura as quantidades do nutriente diminuíram nos tecidos foliares ao passo que as concentrações de ácido urônico presentes na parede celular não apresentaram mudanças. Em soluções com 0 molar de boro, todo o boro presente nos tecidos relacionou-se com a parede celular.

Estes dados corroboraram os resultados apresentados por alguns autores que concluíram que 95 a 98\% do boro presente em plantas deficientes estão presentes na parede celular (Matoh et al., 1992; Hu \& Brown, 1994).

$\mathrm{Hu}$ et al. (1996), ainda observaram que quando o boro é omitido do meio de crescimento, a concentração de boro foliar era muito baixa. Entretanto, a quantidade de ácido urônico da parede não foi reduzida sugerindo que o conteúdo de pectina que existe na célula não é alterado pela deficiência de boro. No entanto, a deficiência de boro inibe rapidamente o crescimento de novas plantas, portanto o microelemento deve estar envolvido no processo de divisão celular, expansão celular ou síntese da parede celular (incluindo pectinas) (Hu \& Brown, 1994). Quando o suprimento de boro é aumentado de 0 para $50 \mathrm{nM}$, ocorre um aumento de três vezes na concentração de boro nos tecidos e na parede celular de todas as espécies analisadas. Este aumento uniforme do boro na parede 
celular, que é proporcional ao conteúdo de pectinas, sugere que o conteúdo de cada pectina pode ligar o boro adicional se este estiver presente. Entretanto, quando este é suplementado com quantidades adequadas $(50 \mathrm{nM})$ uma porção do boro não se encontra ligada as pectinas da parede celular enquanto em plantas deficientes todo o boro presente se associa com a fração de pectinas e esta indisponível para a translocação ou uso em outras reações metabólicas.

$\mathrm{Hu}$ et al. (1996), analisaram diversos açúcares (arabinose, fucose, galactose, glucose, manose, rhamnose e xilose), onde somente rhamnose e galactose mostraram uma correlação positiva com o boro da parede celular. Com exceção de rhamnose em cenoura, a reação entre o boro da parede e a rhamnose e a galactose assemelha-se com o boro da parede e o ácido urônico. Uma vez que, a rhamnose e a galactose são predominantemente encontradas em associação com resíduos de ácido urônico, os resultados fortalecem a hipótese de que o boro esta largamente associado com pectinas na parede celular.

\subsubsection{Membrana plasmática}

O boro tem um importante papel na integridade estrutural e funcional das biomembranas (Parr \& Loughman, 1983; Marschner, 1995). Cakmak \& Römheld (1997) afirmam que a manutenção da integridade da membrana plasmática esta relacionada principalmente com o papel estrutural do boro nas membranas. A função de proteção do microelemento contra radicais livres, pode ser particularmente importante sob condições de alta intensidade luminosa e em plantas que acumulam altas quantidades de fenóis em resposta a deficiências por boro.

Tanada (1983) demonstrou que as membranas plasmáticas contêm uma quantidade relativamente alta de boro quando comparadas com protoplastos isolados de hipocótilos de Phaseolus mungo. Entretanto, dados sobre a existência e a natureza de complexos com boro dentro e/ou na membrana plasmática não têm sido elucidados. Não são relatados estudos envolvendo o papel da nutrição por boro nos canais de íons. 
A formação de complexos fenólicos pode ser relevante para a integridade da membrana por diversas razões. Tem sido sugerido que a deficiência por boro aumenta a passagem de íons através da membrana, e este aumento de fluxo pode ser uma conseqüência dos danos peroxidativos e alterações estruturais na membrana causadas por $\mathrm{O}_{2}$ (oxigênios) tóxicos (Cakmak et al., 1995).

Em alguns casos, tem sido mostrado que a deficiência de B está associada com uma alteração substancial e rápida no fluxo de íons. Esta interferência do boro nos fluxo de íons pode ser também mediada pelos efeitos diretos e indiretos do B nas ligações da membrana plasmática e o bombeamento de prótons das ATPases (Cakmak \& Romheld, 1997).

Tanada (1995) propôs que o boro é requerido para sistemas que geram as mudanças de cargas positivas nas membranas. Entretanto, o micronutriente pode influenciar o influxo de íons através das membranas. De acordo com o autor, a geração de cargas positivas é causada pela habilidade do boro em capturar elétrons dos compostos que formam a membrana, principalmente de compostos contendo sulfihidril.

\subsection{Cálcio}

\subsubsection{Forma disponível e concentrações adequadas}

O cálcio é um cátion bivalente $\left(\mathrm{Ca}^{+2}\right)$ localiza-se no apoplasto em uma forma trocável na parede celular e na superfície exterior da membrana plasmática. Sua taxa de absorção no citoplasma é severamente restrita e parece ser duplamente perdida somente em processos metabólicos. É um nutriente não tóxico, mesmo em altas concentrações, sendo muito eficiente em processos de desintoxicação à outros elementos presentes em doses elevadas nas plantas. Sua mobilidade entre células e no floema é muito baixa, podendo ter atividade citoplasmática (Marschner, 1995).

O cálcio encontra-se principalmente nas folhas vegetais e, como não se transloca, é detectado em maiores quantidades nas folhas velhas. A maior parte do cálcio aparece na lamela média das paredes celulares, como sais de compostos pécticos sua 
concentração no citossol é baixa quando comparada com a do vacúolo e de outras organelas (Mascarenhas, 1977). Surge também nos vacúolos celulares, sob a forma de cristais insolúveis.

A maior importância do cálcio para a planta é como nutriente, sendo indispensável também nos pontos de crescimento (meristemas) onde se processa a divisão mitótica, bem como no desenvolvimento radicular, atuando nos processos de alongamento celular, desintoxicação dos íons hidrogênio e divisão celular. Os cátions de cálcio se combinam com grupos carboxílicos de ácido péctico dando origem ao pectato de cálcio que juntamente com o pectato de magnésio, formam lamela média da parede celular, responsável pela ligação das células adjacentes (Mascarenhas, 1977).

O macronutriente tem muitas funções no crescimento e desenvolvimento vegetal. $\mathrm{O}$ atraso no amadurecimento dos frutos e na senescência e abscisão foliar; a melhoria da qualidade dos frutos e hortaliças e as alterações na resposta geotrópica, na fotossíntese e em outros processos como: divisão celular, movimentos citoplasmáticos e aumento do volume celular são apenas algumas funções do cálcio nas plantas (Malavolta et al., 1997). O cálcio também está diretamente envolvido nas funções do citoesqueleto (Feijó et al., 1995; Malho \& Trewaras, 1996).

A concentração deste elemento nas plantas varia com a idade, parte da planta, espécie, enraizamento ou tipo de solo. Para Hale \& Orcutt (1987), a média ideal da concentração de cálcio no tecido seco gira em torno de $0,5 \%$ e no solo ao redor de 0,43\%. Para Marschner (1995), estas concentrações em tecidos sadios de plantas variam entre 0,1 a $5,0 \%$ na matéria seca.

A maioria dos estudos com auxinas, giberelinas, citocininas e geotropismo, tem usado concentrações de cálcio entre $-0,1$ e $10 \mathrm{mM}$, uma quantidade centenas de vezes maior do que a célula necessita (Hepler \& Wayne, 1985).

\subsubsection{Sintomas de deficiência nutricional}

Uma planta encontra-se deficiente quando o nível de nutriente no tecido vegetal, não promove o seu desenvolvimento adequado ou crescimento ótimo. Os desarranjos 
metabólicos causados pela deficiência de elementos essenciais se manifestam em anormalidades visíveis. $\mathrm{O}$ crescimento global e o desenvolvimento da planta podem ser afetados gerando sintomas macroscópicos característicos (Epstein, 1982).

Mengel \& Kirkby (1987) descreveram os sintomas da deficiência de cálcio apresentando uma redução no crescimento do tecido meristemático, observada primeiramente na região do crescimento apical e nas folhas mais novas. Havendo deformação e clorose foliar e nos estágios mais avançados um pronunciamento da necrose das margens das folhas e dos tecidos afetados que se tornaram moles devido à dissolução da parede celular.

Outros sintomas da ausência de cálcio incluem clorose generalizada, exceto ao longo dos vasos (encarquilhamento), baixo desenvolvimento das raízes que apresentam aspecto gelatinoso e frutificação heterogênea (Ting, 1982).

Malavolta et al. (1997) aferem que as ausências do cálcio em organismos vegetais promoveram alterações na resposta geotrópica, interferências na divisão celular, desorganizam os movimentos citoplasmáticos, diminuem o volume celular e ainda geram atrasos no amadurecimento, na senescência e na abscisão de frutos e folhas.

Várias desordens fisiológicas estão relacionadas com o baixo teor de cálcio nos tecidos como: o "bitter pit" (mancha preta) em culturas de maçãs, a podridão estilar ou fundo preto, o coração negro em frutos de tomateiro e o coração negro oco em culturas de tubérculos de batatas. O aumento no nível de cálcio em geral diminui a ocorrência ou severidade dessas desordens. Todas essas desordens têm sintomas similares de encharcamento dos tecidos, característica da perda da integridade da membrana e aumento do escoamento (Malavolta et al., 1997). Barros et al. (1990) em suas pesquisas sugeriram que a seca de ponteiros, freqüentemente observada em árvores durante períodos de seca prolongada no Brasil, parece estar relacionada à deficiência de cálcio.

Plantas de Coffea arábica sob condições de deficiência de cálcio apresentaram redução no nível de clorofila e proteínas solúveis (Ramalho \& Nunes, 1999; Ramalho et al., 1995). Arruda et al. (2001), ao analisarem calos cultivados em diferentes 
concentrações de cálcio em meio de cultura, verificaram grandes desordens celulares, com presença de células colapsadas e desagregadas.

Silveira et al. (2001) verificaram em áreas florestadas com Eucalyptus deficientes em cálcio, a deformação de folhas novas seguida de enrolamento, com morte das gemas apicais e em estádios avançados de desenvolvimento, seca dos ponteiros.

Em análises realizadas in vitro, Higashi (1996) concluiu que a ausência de cálcio em soluções nutritivas ocasiona deformação e impariamento das folhas nos três híbridos de Eucalyptus estudados e após 21 dias de cultivo in vitro observou quedas de folhas e ramos.

Os estudos de Mengel \& Kirkby (1987) e Zekri (1995) mostraram que processos de deficiência nutricional podem ser detectados quando existe deficiência hídrica que são os responsáveis por reduzir as concentrações de cálcio nas planta. Todavia o trabalho de Abdel-Basset (1998) indicou que a adição de cálcio ao substrato das plantas reduziu os efeitos de deficiência hídrica, promovendo o aumento de peso seco, conteúdo de água e clorofila. Ballester-Fernadez et al. (1997) também verificaram um aumento do crescimento de plantas sob estresse hídrico após adição de cálcio.

\subsubsection{Sintomas de toxidez nutricional}

Sintomas de toxidez por doses de cálcio não têm sido relatados de forma freqüente na literatura. Bergmann (1992) comenta que o excesso de cálcio pode ser observado principalmente através da clorose, mais comum em vários gêneros de frutíferas e plantas ornamentais.

De acordo com Gonçalves ${ }^{1}$, o excesso do macronutriente levaria as plantas a apresentarem sintomas nutricionais característicos de outros nutrientes mascarando a sua atuação dentro da planta. Marschner (1995) considera o nutriente como não tóxico, mesmo quando se encontra em altas concentrações, sendo muito eficiente em processos de desintoxicação a outros elementos presentes em doses elevadas nas plantas.

\footnotetext{
${ }^{1}$ GONÇALVES, A.N. Comunicação pessoal, 2004
} 
Marschner (1995) comenta ainda que folhas que receberam altas doses de cálcio durante o crescimento ou sob condições de alta intensidade luminosa, apresentam uma grande proporção do material péctico na forma de pectato de cálcio. Isto faria com que o tecido se tornasse fortemente resistente a degradação pela poligalacturonase.

\subsubsection{Prováveis funções celulares}

A maioria das suas atividades esta relacionada com a capacidade de coordenação, providenciando estabilidade e ligações intermoleculares reversíveis, predominantemente na membrana plasmática e parede celular (Marschner, 1995). Poovaiah \& Reddy (1987) comentam que devido a semelhança de raio iônico, outros cátions poderiam substituir os sítios de ligação do cálcio, mas eles não estariam capacitados para substituir o cálcio em uma de sua principais funções, ou seja, a de estabilizador da membrana. Para Malavolta (1980), quanto maior a presença no meio de íons potencialmente prejudiciais, mais crucial parece ser o papel do cálcio na manutenção da integridade da membrana.

De acordo com Poovaiah (1985), o íon tem um importante papel no crescimento e desenvolvimento da planta e segundo Ting (1982), interfere também no metabolismo vegetal. Desta forma Marschner (1995), considera o nutriente como mediador de muitas reações químicas e/ou bioquímicas, relacionando-se com os mecanismos envolvidos nos processos de crescimento e desenvolvimento da planta.

A maior importância do cálcio para a planta é como nutriente, sendo também indispensável nos pontos de crescimento (meristemas) onde se processa a divisão mitótica contínua, bem como no desenvolvimento radicular, atuando nos processo de alongamento celular; desintoxicação dos íons hidrogênio e divisão celular. Os cátions de cálcio se combinam com grupos carboxílicos do ácido péctico dando origem ao pectato de cálcio que, juntamente com o pectato de magnésio, formam a lamela média da parede celular, responsável pela ligação de células adjacentes (Mascarenhas, 1977).

A existência de uma correlação positiva entre a plasticidade da parede celular e o crescimento da célula, tem sido demonstrado. Isso denota que durante a expansão celular 
há um aumento na plasticidade da parede celular. Desta forma, a plasticidade é decorrente de uma alteração entre íons e ligações covalentes com a parede celular, sendo a pectina a responsável pela ligação do cálcio com a parede celular (Ting, 1982).

Verificou-se também a ação do cálcio na manutenção da integridade da membrana e sua ausência causa mal funcionamento e seletividade de transporte (Takeda et al., 1998).

A observação da resposta metabólica de células de eucalipto e girassol sob estresse hidrodinâmico mostrou que o cálcio do citossol funciona como um mensageiro de segunda ordem, mediando o sinal do estresse hidrodinâmico dentro do metabolismo, o que induz o decréscimo da taxa de respiração (Takeda et al., 1998).

Em organelas celulares o cálcio é também detectado em vacúolos, nos cloroplasto (atuando como sítios de acúmulo do nutriente) e nas mitocôndrias (Larkum, 1968).

Os cloroplastos atuam como sítios acumuladores de cálcio (Larkum, 1968) e as mitocôndrias têm sua função e estrutura influenciada pelo macronutriente, ao mesmo tempo em que facilitam o transporte intracelular do cálcio e o seu controle dentro do citoplasma (Marmé, 1983). Borle (1981) verificou que durante a divisão celular existe um aumento da permeabilidade da membrana plasmática em relação ao cálcio, fato que levaria ao acúmulo destes íons em mitocôndrias. Nestes casos, as mitocôndrias serviriam como reservatório intracelular e seqüestrariam o cálcio excedente do citoplasma.

Em estudos posteriores, Akerman \& Nicholls (1983) verificaram que a capacidade de estoque nas mitocôndrias é limitada e os efeitos destas altas concentrações podem ser tóxicos às células vegetais.

A concentração de cálcio no citossol é baixa quando comparada com a do vacúolo e de outras organelas. Tal concentração é garantida pela ação de ATPases transportadoras de cálcio localizadas no plasmalema, as quais retiram o elemento do citossol. A atividade dessas ATPases, por sua vez, são controladas por proteínas reguladoras, as calmodulinas, que se combinam com o cálcio. $\mathrm{O}$ aumento da concentração de cálcio $\left(\mathrm{Ca}^{+2}\right)$ no citossol ativa a calmodulina que por sua vez, ativa 
várias enzimas, o que leva a uma resposta da planta. Esta baixa concentração é garantida pela ação de ATPases transportadoras de cálcio localizadas no plasmalema, as quais retiram o nutriente do citossol. A atividade dessas ATPases, por sua vez, são controladas por proteínas reguladoras, as calmodulinas, que se combinam com o cálcio. A calmodulina, ativa também a Ca-ATPase que bombeia o cálcio de volta aos seus reservatórios. Com isso , o cálcio do citossol diminui e os níveis de ativação enzimática efetuada pela calmodulina decrescem (Trewavas \& Knight, 1994; Malavolta et al., 1997; Alberts et al., 1997).

As calmodulinas não têm atividade enzimática, mas modulam, associadas ao cálcio a atividade de enzimas e de proteínas não enzimáticas (Malavolta et al., 1997). Segundo Marmé (1988), a fosforilação protéica em plantas pode ser regulada pelo cálcio sob concentrações fisiológicas sendo a última parte dessa regulação mediada pela calmodulina.

Pesquisas recentes têm deixado claro que o cálcio atua como mensageiro intracelular acoplado a diversos sinais extracelulares para respostas específicas. Foram descritos 4 tipos de proteínas sensíveis ao cálcio em plantas: proteínas-quinases dependentes de cálcio; calmodulinas; outras proteínas associadas ao cálcio com motivos "EF-hand"; proteínas associadas ao cálcio sem motivos "EF-hand" (Reddy, 2001). O mesmo autor sugere que o cálcio serve como mensageiro em muitos processos de crescimento e desenvolvimento em respostas ao estresse biótico e abiótico, sendo que somente as proteínas quinases e as calmodulinas atuam em genes reguladores de estresse.

Stefanuto (2002) concluiu que a dose de cálcio de 2,5 mM.L ${ }^{-1}$ adicionada em meio de cultura foi a mais eficaz na tolerância a deficiência hídrica e capacidade homeostática. Confirmando as afirmações de que o cálcio realmente atua como atenuante aos danos causados por estresse hídrico.

De acordo com Malho et al. (1999), ondas de cálcio são geradas em pontos específicos da célula (vacúolo, cloroplastos, mitocôndrias e retículos endoplasmático) em função de sinais externos ativando a síntese de proteínas específicas. 
Alguns autores avaliaram a ação do cálcio na embriogênese somática $\mathrm{e}$ constataram a sua ação na formação de embriões somáticos, no crescimento polarizado, na mitose e nas correntes citoplasmáticas (Hepler \& Wayne, 1985; Hause et al. 1994; Arruda et al. 2001). Arruda et al. (2001) concluíram que doses crescentes de cálcio aumentaram a produção de carboidratos solúveis totais, proteínas totais, peroxidase e doses específicas do macronutriente $\left(4,12\right.$ e $\left.6,12 \mathrm{mM} \cdot \mathrm{L}^{-1}\right)$ em culturas in vitro de calos de E. urophylla favoreceram o aparecimento de embriões somáticos.

\subsubsection{Principais atuações celulares}

\subsubsection{Parede celular}

Existem na parede celular duas áreas distintas com elevadas concentrações de cálcio: a lamela média e a superfície exterior da membrana plasmática. Nas duas áreas, o cálcio tem funções principalmente estruturais essenciais, embora atue na permeabilidade e em processos relacionados. Ao contrário dos outros macronutrientes, uma alta proporção do total de cálcio nos tecidos vegetais é localizada na parede celular (apoplasto). Esta distribuição é resultado do grande número de sítios de ligações para o cálcio nas paredes das células, como o transporte restrito do macronutriente através da membrana plasmática ao citoplasma. Na lamela média, encontra-se ligado com grupos $\mathrm{RCOO}^{-}$dos ácidos poligalacturônicos (pectinas) na forma trocável. As formas de cálcio, mais comuns são: pectato, oxalato e fosfato de cálcio (Marschner, 1995).

\subsubsection{Membrana celular}

O papel fundamental do cálcio na estabilização da membrana e na integridade celular é refletido de várias formas. Isto pode ser demonstrado pelo aumento da perda dos solutos de baixo peso molecular das células e dos tecidos e também pela desintegração da membrana de estruturas celulares e perda da compartimentalização celular (Langer, 2000). 
A função do cálcio no funcionamento da membrana é dupla pois mantém a impermeabilidade aos íons tornando o transporte por difusão mínimo e garantindo a seletividade dos mecanismos de transporte iônico (Epstein, 1982).

O cálcio estabiliza as membranas celulares por trazer grupos de fosfato, carboxilas de fosfolipídeos e proteínas, preferencialmente para a superfície da membrana. Pode existir a troca do cálcio por outros íons nos sítios de ligação, como o K (potássio), $\mathrm{Na}$ (sódio), $\mathrm{Mg}$ (manganês) ou $\mathrm{H}$ (hidrogênio), no entanto estes elementos não são capazes de substituir o cálcio em seu papel de estruturação (Marschner, 1995).

\subsection{Interação entre cálcio e boro}

Diversos autores registram na literatura a importância do boro e do cálcio, entretanto existem poucos registros da atuação celular destes dois elementos de forma conjunta. Deficiências de boro em plantas superiores têm sido registradas quando ocorre um aumento no suplemento de cálcio (Gupta, 1979).

A razão cálcio / boro em folhas tem sido usada como índice para a diagnose da toxidez de boro e também para indicar a nutrição do micronutriente por produtos agrícolas (Gupta, 1979).

A concentração no solo ou solução nutritiva e a razão cálcio / boro nos tecidos da planta podem exercer uma influência significativa na toxidez de boro. Eck \& Campbell (1962) atribuíram o decréscimo da absorção de boro, a altas concentrações de cálcio. Tanaka (1967), reportou que em soluções nutritivas, a absorção de boro em rabanete (Raphanus sativus), foram reduzidas com o aumento da concentração de cálcio do meio. Outros estudos mostraram que a adição de cálcio em água de irrigação pode resultar em pouco acúmulo de boro nas plantas (Nable et al., 1997).

Sotiropoulos et al. (1999), em experimentos realizados com frutos de kiwi concluíram que altas concentrações de cálcio na solução nutritiva, podem reduzir a absorção de boro por estas plantas. A deficiência de boro é responsável por alterações na translocação de cálcio em brotos e frutos (Yamauchi et al., 1986). 
Em experimentos realizados com Pisum sativum, Carpena et al. (2000) buscaram evidenciar o papel específico do boro e cálcio na fixação de nitrogênio e concluíram que altos suprimentos de boro podem induzir a mobilização do nutriente em raízes e altas concentrações de boro em nódulos de plantas de ervilhas podem contribuir para uma baixa atividade da nitrogenase.

Interações entre cálcio e boro parecem ocorrer ao nível da membrana (Parr \& Longhman, 1983) e parede celular, mas os mecanismos envolvidos na interação dos efeitos dos dois íons não são claros.

A parede celular de plantas tem sido proposta como o sítio de ligação do boro, o qual influencia o metabolismo do cálcio. Yamauchi et al. (1986), mostrou que a deficiência de boro induz a diminuição na quantidade de cálcio associado com pectinas da parede celular em folhas de tomate.

Teasdale \& Richards (1990), estudaram a relação boro/cálcio na estrutura e função da parede celular de Pinus radiata e sugeriram um modelo no qual o aceptor crítico de moléculas é ativado em sítios diferentes somente por ligações de cálcio e boro. Os autores ainda encontraram que o macro e o micronutriente podem atuar como aceptores concorrentes na membrana, sendo que o boro liga-se de forma mais forte que o cálcio evidenciando o papel do microelemento na biossíntese da parede celular.

Este tipo de interação iônica tem sido estudada amplamente em plantas superiores, no entanto, também podem ser encontradas em cianobactérias (Bonilla et al., 1995).

\subsection{Análises bioquímicas}

\subsubsection{Aminoácidos e proteínas}

A determinação do teor de aminoácidos a partir de extratos vegetais é muito utilizada nas pesquisas fisiológicas, pois a reação de uma planta ou de seus órgãos a um ferimento ou uma situação de estresse, provoca a síntese de proteínas, podendo então ser caracterizada pela composição dos aminoácidos produzidos (Passos, 1996). 
Os aminoácidos são compostos básicos para a biossíntese de proteínas, ácidos nucléicos e substâncias nitrogenadas do metabolismo secundário. Esses compostos são importantes para a construção das substâncias corpóreas das plantas (Malavolta, 1997; Larcher, 2000).

As proteínas são moléculas complexas constituídas por seqüências de aminoácidos. Cada proteína e formada por uma seqüência única de aminoácidos, o que determina a sua função dentro da célula (Brum et al., 1994). A síntese de proteínas é a função central de todas as células. Na sua ausência o crescimento e a manutenção dos órgãos cessam e isso representa um fator limitante à taxa de crescimento das plantas. Esta síntese requer uma demanda por aminoácidos, um alto suprimento em energia e nutrientes (Porter et al., 1991).

Trevizam (2001) ao analisar calos de E. urophylla em cultivo in vitro verificou que o boro interfere na quantificação de proteínas solúveis totais. De acordo com o autor diante das doses avaliadas a que apresentou melhores resultados foi $50 \mu \mathrm{M}$ de boro enquanto nas doses inferiores existiu um acréscimo até a concentração padrão com posterior decréscimo em doses superiores. Ao analisar as doses de um aminoácido específico (prolina) verificou que em tratamentos com excesso ou toxidez de boro o acúmulo do aminoácido apresentou-se duas vezes superior as concentrações encontradas em outros tratamentos.

Arruda et al. (2001) analisaram a interferência do cálcio em quantificações de proteínas totais e verificaram que doses crescentes do macronutriente determinaram o aumento nas concentrações do cálcio em calos de E. urophylla cultivados in vitro.

\subsubsection{Eletroforese de proteínas solúveis totais em gel de poliacrilamida (SDS- PAGE)}

A eletroforese é uma técnica de separação de moléculas que consiste na migração de moléculas com carga, numa solução, em função da aplicação de um campo elétrico. A velocidade da migração depende da força do campo aplicado, da carga, do tamanho e da forma das moléculas e também da força iônica, viscosidade e temperatura do meio, onde estas moléculas se movem. De um modo geral, no transporte eletroforético, à força 
do campo opõe-se a resistência do meio, produzindo uma velocidade constante das partículas (Alfenas, 1991).

Esta técnica pode ser usada para análise de proteínas. As proteínas são moléculas anfotéricas, cujas cargas são determinadas pelo pH do meio onde estão suspensas. Numa solução com $\mathrm{pH}$ acima do ponto isoelétrico, as proteínas negativamente carregadas migram para o ânodo do campo elétrico. Abaixo do ponto isoelétrico, as proteínas são positivamente carregadas e migram para o cátodo (Alberts et al., 1997).

O objetivo do SDS é desnaturar as proteínas, isto é, convertê-las em uma estrutura linear e conferir-lhe densidade de carga uniforme, de forma a poderem ser separadas por eletroforese, somente, em função da massa molecular ou seja do seu tamanho (Alberts et al., 1997).

O SDS tem uma alta carga negativa e pH 7 com uma cauda hidrofóbica que interage com as cadeias das proteínas (polipeptídeos). O número de moléculas de SDS que se ligam às proteínas são proporcionais ao número de aminoácidos que constituem as mesmas, pois liga-se na razão de uma molécula por ligação peptídica. Se as proteínas desnaturadas são postas num campo elétrico, todas elas se moverão para o pólo positivo, na mesma proporção, sem possibilidade de avaliar a distância migrada. Então, é necessário colocá-las num ambiente que permita que proteínas de variados tamanhos se desloquem a velocidades diferentes, sendo o meio adequado o gel de poliacrilamida (polímero de monômeros de acrilamida). Com a aplicação de uma corrente elétrica as moléculas movem-se ao longo do gel de poliacrilamida, migrando mais rapidamente as proteínas que possuem dimensões menores (Alberts et al., 1997).

\subsubsection{Carboidratos}

Os carboidratos constituem um grupo de compostos que incluem açúcares simples e moléculas mais complexas constituídas por subunidades de açúcares mais simples, cuja principal função é o fornecimento de energia química aos processos celulares (Brum et al., 1994). De acordo com Vieira et al. (1991), outras funções atribuídas aos carboidratos são: fontes de reserva, sustentação (como no caso da celulose e hemi-celulose) e defesa (glicoproteínas e imunoglobulinas entre outras específica). 
As relações existentes entre os teores de carbono e um nutriente específico indicam se uma deficiência nutricional limita o crescimento da planta, mais do que uma deficiência na disponibilidade por luz. O crescimento limitado indica que o excesso de carbono foi afastado da produção de metabólicos secundários constituídos de carbono (Hakulinen, 1998).

\subsection{Cultura de tecidos}

\subsubsection{Calogênese}

Considera-se que todas as células vivas dentro da planta apresentam uma capacidade potencial de regenerar um organismo inteiro, ou seja, possuem autonomia para expressar sua totipotência (Fosket, 1994), desde que submetidas a tratamentos adequados (Kerbauy, 1999). Portanto, todas as células possuem autonomia potencial para regenerar integralmente uma planta desde que submetidas a tratamentos adequados (Kerbauy, 1999).

A cultura de tecidos vegetais é a expressão utilizada para designar a cultura in vitro de células, tecidos e órgãos de plantas, que além de proporcionar variação genética, condição essencial para a seleção de genótipos superiores, amplia os conhecimentos para a compreensão dos fenômenos bioquímicos e fisiológicos responsáveis pelo crescimento e desenvolvimento das plantas (Gallo \& Crocomo, 1995). Estas técnicas de cultura de tecidos têm sido aplicadas de diferentes formas em programas de melhoramento, na conservação e avaliação de germoplasma, aumento da variabilidade genética para fins de seleção, na introgressão de genes de interesse, para acelerar programas de melhoramento e na clonagem de genótipos (Sá et al., 2000). A cultura de calos, suspensões celulares e cultura de protoplastos são de relevante importância nas investigações de diferenciação celular e de biologia molecular (Veasey et al., 1991).

Através da cultura de células, linhas de células mutantes com resistência a antibióticos, herbicidas, aminoácidos e seus análogos, toxinas fúngicas e tolerância a estresse ambiental têm sido selecionadas (Bhojwani \& Razdam, 1996). 
Outra aplicação da cultura de células está relacionada com a produção de metabólitos secundários na área industrial. Células vegetais mantidas em suspensão líquida em biorreatores produzem produtos de seu metabolismo, entre eles alcalóides, corantes, antioxidantes e taninos (Crocomo, 1988).

Quando um explante é excisado da planta doadora e inoculado em meio de cultura, um dos eventos mais comuns é a formação de uma massa de células não diferenciadas, com proliferação contínua e desordenada, denominada calo (Handro \& Floh, 1990). De acordo com Stafford \& Warren (1991), o estabelecimento da cultura de calos a partir de explantes (raiz, caule, folha, flor, etc) é dividido em três etapas: 1) indução (ativação do metabolismo para a desdiferenciação e divisão celular); 2) divisão (as células dividem-se ativamente em células de tamanho menor); e 3) diferenciação (as células tornam-se maiores, vacuolizadas e a taxa de divisão diminui, e então ocorre o equilíbrio entre a divisão e a expansão celular).

Muitos são os fatores que influenciam o comportamento do explante no meio de cultura, incluindo o órgão que serve como fonte de tecido, a idade fisiológica e ontogenética do órgão, o tamanho do explante e acima de tudo a qualidade da planta doadora (Thorpe \& Patel, 1984). O controle da qualidade do material vegetal em si e a manipulação desde o início do isolamento do explante são aspectos importantes na cultura de tecidos. Esta manipulação inclui o manejo cultural e ambiental da planta matriz, pois o estado nutricional, fisiológico e fitossanitário desta tem grande influência no posterior comportamento do explante e da cultura. Plantas bem nutridas, sem sintomas de deficiência nutricional ou hídrica, em geral fornecem explantes de melhores qualidades (Grattapaglia \& Machado, 1990).

Quando um explante é inoculado in vitro, diversas respostas são esperadas e a determinação de fatores químicos e características fisiológica dos tecidos de plantas doadoras têm sido crucial (Borgatto et al., 2002). Hayashi et al. (2002) não observaram efeitos significativos do tratamento com nitrogênio na calogênese (índice de multiplicação celular e massa de matéria seca de calos) para os explantes de entrenós e nó quando avaliados nas três épocas de coleta (30, 45 e 60 dias). Em tratamentos 
mantidos em cultivo por períodos mais prolongados (45 e 60 dias), os autores aferem que houve uma resposta negativa da calogênese, sendo portanto inversamente proporcional a concentração de nitrogênio na solução nutritiva. Contrariamente, Borgatto et al. (2002) descrevem que para os estudos realizados com Chrysanthemum morifolium verificaram que o tratamento de plantas matrizes com nitrogênio afetou a calogênese in vitro, evidenciando a importância do estado nutricional das plantas matrizes fornecedoras dos explantes. Relatam também uma maior taxa de calogênese em explantes de entrenós de Chrysanthemum morifolium quando submetidos a tratamentos de longa duração (60 dias).

Em estudos com fitormônios vegetais, Gomes et al. (2004) demonstraram a formação de calos a partir de tecidos originários do eixo embrionário de embriões zigóticos de coqueiro (Cocos nucifera L.) em diferentes concentrações de 2,4-D (ácido 2,4 diclorofenoxiacético) e concluíram que as concentrações que melhor induziram a formação de calos, foram as de $10^{-4} \mathrm{M}$ e $1,36 \times 10^{-4} \mathrm{M}$; houve formação de calos aos 15 dias a partir de segmentos próximos à zona meristemática do eixo embrionário e os segmentos do eixo embrionário seccionados na região apical do eixo embrionário e na região basal do eixo embrionário apresentaram melhores resultados para calogênese nas concentrações analisadas.

\subsubsection{Embriogênese somática}

A cultura de células e tecidos in vitro, inclui a organogênese e embriogênese somática (Christianson \& Warnick., 1988), sendo esta última especialmente importante para a propagação de plantas in vitro em larga escala, além de uma maneira estratégica para os estudos básicos relacionados com a fisiologia do desenvolvimento do embrião (Yeung, 1995).

A embriogênese desenvolve-se através de um processo onde células haplóides, produzem plantas diferenciadas através de estágios embriológicos distintos, sem a fusão de gametas, apresentando embrião somático com aspecto bipolar e sistema vascular 
fechado (Williams \& Maheswaran, 1986; Schumann et al., 1995; Guerra et al., 1999), sem conexão com tecidos do explante inicial (Guerra et al., 1999).

Considerando-se o potencial de multiplicação e custos envolvidos, a embriogênese somática apresenta grandes vantagens em relação a outros sistemas de propagação, visto que enormes quantidades de embriões podem se formar utilizando-se uma manipulação manual mínima e a utilização de pouco espaço físico (Grattapaglia \& Machado, 1990).

A observação de embriões somáticos em cultura de células vegetais foi primeiramente observada por Steward et al. (1958) e Reinert (1958), em calos de cenoura (Torres et al., 1998). A partir deste período observou-se um número crescente de espécies e tecidos que são utilizados para induzir embriões somáticos. Devido a estes fatores nota-se uma tendência contínua de estudos que buscam obter maior conhecimento sobre o processo e maior habilidade de exploração. Sabe-se que apesar dos embriões somáticos serem originados a partir de células somáticas, estes se assemelham muito aos zigóticos, presumindo-se que possam resultar da expressão gênica que regula a mesma via de desenvolvimento (Parrot et al., 1991).

Os padrões de desenvolvimento de um embrião somático em dicotiledôneas apresentam muitas características morfológicas semelhantes as do embrião zigótico. Ambos são caracterizados pela diferenciação de uma estrutura bipolar, constituída de ápice caulinar e radicular. Ambos passam por estádios de desenvolvimento próembrionário e embrionário propriamente ditos: globular, cordiforme, torpedo e cotiledonar (Zimmermann, 1993).

Os embriões somáticos diferem dos zigóticos em relação ao desenvolvimento livre de correlações físicas, fisiológicas e genéticas, as quais ocorrem durante o desenvolvimento do embrião zigótico (Zimmermann, 1993). Uma característica peculiar aos embriões somáticos é a presença de sistema vascular fechado, sem conexão vascular com os tecidos do explante inicial. Esta característica, aliada à bipolaridade difere os embriões somáticos dos propágulos resultantes dos processos de micropropagação e organogênese (Guerra et al.,1999). 
Quanto à forma de ocorrência, a embriogênese somática pode apresentar-se in vivo ou in vitro. No primeiro caso, células do tecido embrionário podem ser direcionadas para esta rota de desenvolvimento, como acontece com o sistema de embriogenia adventícia ou nucelar em Citrus spp. onde embriões apomíticos se originam por gemação a partir de células do nucelo (Spiegel-Roy \& Vardi, 1984). A conseqüência deste fenômeno é a perpetuação de populações clonais por meio da semente (Zimmermann, 1993; Guerra et al, 1999).

$\mathrm{Na}$ embriogênese somática in vitro, células em diferentes estádios de diferenciação podem ser induzidas por estímulos ambientais ou químicos e, se reprogramadas, podem adquirir novas competências morfogenéticas (Guerra et al.,1999).

Segundo Sharp et al. (1982), existem dois padrões básicos da expressão da embriogênese somática in vitro: o direto e o indireto. A embriogênese somática direta caracteriza-se por originar os tecidos matrizes sem a formação de estádios intermediários de calo, sendo exemplos os segmentos de pecíolos ou embriões zigóticos. Para Sharp et al. (1982), este tipo de padrão ocorre em células nucelares de variedades poliembriônicas de citros, em embriões imaturos de palmeiras (Euterpe edulis) (Guerra \& Handro, 1988) e em inflorescências de Euterpe edulis (Guerra \& Handro, 1988). Em estudos desenvolvidos por Almeida (1994) ápices caulinares de pupunha (Bactris gasipaes) também apresentaram desenvolvimento direto de gemas e embriões.

Segundo Van der Linder (1990) os padrões diretos de embriogênese somática seriam o resultado de uma ativação de células responsivas contendo receptores para determinados reguladores de crescimento. Estas células seriam rediferenciadas para novas rotas morfogenéticas, gerando células mães embrionárias competentes, capazes de originar populações clonais de células embriogenéticas. Os padrões genéticos de embriogênese somática seriam produtos de desdiferenciação ou rediferenciação de células contendo receptores, gerando células de calos.

Williams \& Maheswaran (1986), sugeriram que a embriogênese somática direta é precedida por células pré-embriogênicas determinadas (PEDCs), requerendo somente 
reguladores de crescimento ou condições favoráveis para o início da divisão celular e a expressão da embriogênese. Por outro lado, o termo célula embriogênica determinada induzida (IEDCs) é usado para identificar células capazes de adquirir o potencial embriogênico durante o período de cultivo. Neste caso, a embriogênese indireta requer a redeterminação de células diferenciadas, a proliferação de calos e o desenvolvimento do estado embriogeneticamente determinado. Segundo Parrot et al. (1991), as IEDC e as PEDC são funcionalmente equivalentes e, portanto, o termo célula embriogênica (EC) pode ser adotado.

A forma de expressão indireta, caracteriza-se pela formação de embriões somáticos a partir de calos os quais apresentam células em diferentes estádios de diferenciação e, conseqüentemente, com diferentes graus de determinação, as quais podem adquirir novas competências mediadas por mensageiros químicos específicos. Um exemplo clássico deste sistema de indução da embriogênese somática indireta, ocorre em tecidos do floema de cenoura (Daucus carota) cultivadas in vitro (Reinert, 1958; Steward, 1958).

Segundo Grattapaglia \& Machado (1990), a grande maioria dos sistemas de embriões somáticos ocorre através do modo indireto.

A regeneração de plantas por via indireta após a produção de calos a partir de células foi caracterizado por estudos morfológicos e histológicos realizados por Schumann et al. (1995), onde detectaram 3 tipos distintos de tecidos de calos com variações na cor, estrutura e resposta morfogenética. O primeiro tipo apresenta calos compactos (globulares ou nodulares), de cor amarelo claro e denso, constituído de pequenas células isodiamétricas; o segundo tipo descrito apresenta calos irregulares, soltos, consistindo de células glandulares arranjadas sem coesão, quanto a cor são mais semi-transparentes do que os anteriores com regiões densas pouco coloridas e finalmente tecidos de calos irregulares pouco coesos, com células alongadas, tubulares, grandes, translúcidas e não morfogênicas. 
De acordo com Schumann et al. (1995), somente no primeiro tipo de calo foi observado o desenvolvimento de camadas de células semelhantes ao procâmbio, fato que coincide com a fase de proliferação.

Divisões internas nestas camadas de células simples originam principalmente divisões periclinais, o que pode determinar o início da embriogênese somática em fase subseqüente, divisões anticlinais resultam na formação de massas de proembriões. Williams \& Maheswaran (1986), demonstraram que o primeiro sinal da embriogênese somática direta é a mudança a partir da divisão anticlinal para a periclinal irregular e divisão oblíqua.

Independente do padrão direto ou indireto, as células mães embriogênicas apresentam um conjunto de características comuns ao comportamento de células embrionárias em divisão ativa. Estas características incluem: tamanho pequeno (100 200 micrômetros), conteúdo citoplasmático denso, núcleo grande com nucléolos proeminentes, vacúolos pequenos e presença de grãos de amido. As propriedades histoquímicas destas células sugerem intensa atividade metabólica e síntese de RNA (Williams \& Maheswaran, 1986).

Em diferentes espécies, as necessidades nutricionais têm sido relacionadas com os processos de embriogênese somática (Thorpe, 1983). Diversas formas do íon nitrogênio aplicadas ao meio de cultura estimulam o processo de embriogênese (Higashi et al., 1997), assim como o boro, cálcio, potássio e os quelatos de ferro que também interferem no estabelecimento do embrião in vitro (Ammirato, 1983).

A composição do meio de cultura, com conseqüente análise do consumo de sais, pode otimizar a composição deste possibilitando um melhor controle dos eventos embriogenéticos (Magnaval et al., 1997).

A concentração e o tipo de carboidrato utilizado também parece possuir efeito na embriogênese, porém os trabalhos desenvolvidos não apontam se esta interferência ocorre na iniciação ou desenvolvimento dos embriões (Guerra et al., 1999). A fonte de carboidrato mais utilizada é a sacarose, embora outros mono e dissacarídeos possam ser empregados. Normalmente, concentrações de $3 \%(\mathrm{p} / \mathrm{v})$ de sacarose são suficientes para 
os processos de iniciação e diferenciação (Guerra et al., 1999). Em Citrus, o carboidrato mais utilizado em meios de cultivo, para o crescimento de calos e células em suspensão é a sacarose (145 mM) (Jumin \& Nito, 1996a, 1996b), porém esta situação não parece ser a melhor condição para a expressão da embriogênese somática.

De acordo com Kochba et al. (1982), a embriogênese somática a partir de calos também é um processo crítico na regeneração de plantas e deve ser otimizada para cada variedade em estudo, especialmente em relação à fonte de carbono adicionada ao meio de cultivo. Vários autores observaram que a alteração do carboidrato no meio de cultivo gerou respostas na indução da embriogênese somática em citros. Button (1978) observou que a sacarose promoveu bom crescimento de calos, entretanto, Kochba et al. (1982) relataram que este carboidrato não estimulou a embriogênese somática, ao passo que a galactose e a lactose estimularam o processo. Ben-Hayyim \& Neumann (1983) e Vu et al. (1993) relatam que a embriogênese somática pode ser estimulada quando a sacarose é substituída por glicerol no meio de cultivo.

Em adição a estes fatores de ordem nutricional, a relação auxina-citocinina, níveis de fitoreguladores utilizados no meio de cultura, concentração de gases in vitro, condições de luz e temperatura, também apresentam limitações ao estabelecimento da embriogênese (Guerra et al., 1999).

Parrot et al. (1995), mencionaram que a exposição a hormônios é um dos mecanismos que influenciam a resposta embriogênica. Uma vez que as EC's foram obtidas, a presença continua de auxinas pode inibir o desenvolvimento normal do embrião somático. Quando as concentrações de auxinas são extremamente altas, o embrião não segue seu desenvolvimento ontogenético normal, podendo apresentar novos embriões somáticos (Parrot et al., 1991; Guerra et al., 1999). Este fato pode ser denominado como embriogênese secundária, recorrente ou repetitiva.

Outras variáveis estão relacionadas a habilidade de regeneração de calos embriogênicos. Kikuchi et al. (1995), analisaram polissacarídeos pécticos e compararam calos embriogênicos e não embriogênicos de cenoura (Daucus carota) e concluíram que os calos embriogênicos formavam um maior número de grupamentos celulares, e que o 
nível de açúcares neutros era maior em relação aos calos não embriogênicos. Através de cromatografia gasosa puderam observar que calos embriogênicos, bem como os embriões somáticos, apresentavam maiores teores de arabinose, enquanto que calos não embriogênicos eram ricos em galactose.

Yeo et al. (1998), analisaram as alterações quantitativas e qualitativas dos polissacarídeos na parede celular durante a embriogênese somática e o desenvolvimento de plântulas de aspargo (Asparagus officinalis L.), concluíram que a arabinose foi mais ativamente sintetizada em calos embriogênicos sendo posteriormente degradadas durante o curso da diferenciação.

De acordo com De Vries et al. (1982), análises revelaram que uns grandes números de proteínas extracelulares são excretados pelas células embriogênicas para o meio de cultura, e que elas podem atuar como marcadores moleculares para distinguir culturas embriogênicas e não embriogênicas; os autores sugerem que algumas das proteínas apresentam também um importante papel na indução e no desenvolvimento de embriões somáticos. 


\section{MATERIAL E MÉTODOS}

\subsection{Obtenção dos explantes}

Para a presente tese, foram utilizadas sementes de Eucalyptus urophylla S.T. Blake fornecidas pelo Instituto de Pesquisas e Estudos Florestais (IPEF) catalogadas como T8A32, lote NA 416 coletadas da população base de Anhembi, SP. Primeiramente, estas sementes foram submetidas a um processo de limpeza que se iniciou com o acondicionamento destas em saquinhos de nylon devidamente lacrados. Após a acomodação do material vegetal, procedeu-se a lavagem em água corrente e detergente neutro por 5 vezes, sendo em seguida transferidas para álcool etílico 100\% por 3 segundos.

Em etapa posterior, as sementes foram imersas em solução de hipoclorito de sódio comercial 70\% (V/V) e permaneceram sob agitação em agitador rotativo (shaker) por 20 minutos.

Após este processo de desinfestação, as sementes foram conduzidas à câmara de fluxo laminar e passaram por 3 lavagens em água esterilizada deionizada, sendo posteriormente retiradas dos saquinhos de nylon e transferidas para meio nutritivo destinado à germinação (20 g de sacarose, $6 \mathrm{~g}$ de agar diluídos em $1000 \mathrm{ml}$ de água destilada deionizada). O processo germinativo do material vegetal ocorreu em sala climatiza de crescimento sob condições controladas de luz (PAR $\left.=50 \pm 2 \mu \mathrm{mol} \cdot \mathrm{m}^{-2} \mathrm{~s}^{-1}\right) \mathrm{e}$ temperatura $\left(26^{\circ} \pm 2{ }^{\circ} \mathrm{C}\right)$ com fotoperíodo de 12 horas por doze dias. Os hipocótilos foram coletados após 21 dias de cultivo sendo em seguida excisados em sua porção mediana com comprimento aproximado de 5 milímetros. Este tecido vegetal foi transferido para meio N7 (Simola, 1985) suplementado com 5 mg. $\mathrm{L}^{-1}$ de Picloram e 1,0 mg. $\mathrm{L}^{-1}$ de caseína hidrolisada, como forma de induzir a formação de calos (Tabela 1). 
Tabela 1. Composição do meio N7 (Simola, 1985)

\begin{tabular}{|c|c|c|c|}
\hline \multicolumn{4}{|c|}{ MEIO N7 } \\
\hline MACRONUTRIENTES & mg.L ${ }^{-1}$ & VITAMINAS & $\mathrm{mg} \cdot \mathrm{L}^{-1}$ \\
\hline$\left(\mathrm{NH}_{4}\right)_{2} \mathrm{SO}_{4}$ & 463,0 & Ácido Nicotínico & 0,5 \\
\hline $\mathrm{KNO}_{3}$ & 2830,0 & Tiamina $\mathrm{HCl}$ & 0,1 \\
\hline $\mathrm{MgSO}_{4} .7 \mathrm{H} 2 \mathrm{O}$ & 185,0 & Piridoxina $\mathrm{HCl}$ & 0,5 \\
\hline $\mathrm{KH}_{2} \mathrm{PO}_{4}$ & 399,5 & Glicina & 2,0 \\
\hline $\mathrm{CaCl}_{2} \cdot 2 \mathrm{H}_{2} \mathrm{O}$ & 166,0 & Meso-Inositol & 100,0 \\
\hline MICRONUTRIENTES & $\operatorname{mg} . \mathrm{L}^{-1}$ & OUTROS & g. $\mathrm{L}^{-1}$ \\
\hline EDTA Férrico & 50 & Caseína Hidrolisada & 1,0 \\
\hline $\mathrm{MnSO}_{4} \cdot 4 \mathrm{H} 2 \mathrm{O}$ & 16,9 & Sacarose & 20,0 \\
\hline $\mathrm{ZnSO}_{4} .7 \mathrm{H} 2 \mathrm{O}$ & 8,59 & Agar & 6,0 \\
\hline $\mathrm{H}_{3} \mathrm{BO}_{3}$ & 6,2 & & \\
\hline KI & 0,83 & & \\
\hline $\mathrm{Na}_{2} \mathrm{MoO}_{4} \cdot 2 \mathrm{H}_{2} \mathrm{O}$ & 0,2505 & & \\
\hline $\mathrm{CuSO}_{4} .5 \mathrm{H}_{2} \mathrm{O}$ & 0,25 & & \\
\hline $\mathrm{CoCl}_{2} \cdot 6 \mathrm{H}_{2} \mathrm{O}$ & 0,25 & & \\
\hline
\end{tabular}

As estruturas calogênicas foram cultivadas por dois períodos distintos, 21 e 31 dias, sendo em seguida transferidas para meio de cultura N7 modificado em relação às concentrações de ácido bórico $\left(\mathrm{H}_{3} \mathrm{BO}_{3}\right)$ e cloreto de cálcio $\left(\mathrm{CaCl}_{2}\right)$. Foram avaliadas 5 concentrações distintas de cálcio e 5 concentrações de boro, realizando-se combinações determinadas dos nutrientes em meio de cultura (Tabela 2). Para o ácido bórico $\left(\mathrm{H}_{3} \mathrm{BO}_{3}\right)$ foram utilizadas as concentrações $0,25,50,100$ e $200 \mu \mathrm{M} . \mathrm{L}^{-1}$ e para cloreto de cálcio $\left(\mathrm{CaCl}_{2}\right)$ utilizou-se $0 ; 3,75 ; 7,5 ; 11,25$ e $15 \mathrm{mM} . \mathrm{L}^{-1}$. Para o vigésimo sexto tratamento (padrão), utilizou-se o meio N7 sem modificações. 
Como forma de facilitar a interpretação dos dados, utilizou-se após a identificação numérica dos tratamentos a letra "a" para os calos avaliados aos 21 dias e a letra "b" para os calos cultivos in vitro por 31 dias (Tabela 2).

Tabela 2. Tratamentos empregados em culturas in vitro de E. urophylla relacionando concentrações de boro e cálcio em períodos distintos

\begin{tabular}{cccc}
\hline \multicolumn{2}{c}{ TRATAMENTOS } & $\begin{array}{c}\mathrm{H}_{3} \mathrm{BO}_{3} \\
\left(\mu \mathrm{ML}^{-1}\right)\end{array}$ & $\begin{array}{c}\mathrm{CaCl}_{2} \\
\left(\mathrm{mML}^{-1}\right)\end{array}$ \\
\hline 1 dias & 31 dias & 0 & 0 \\
$2 \mathrm{a}$ & $1 \mathrm{~b}$ & 0 & 3,75 \\
$3 \mathrm{a}$ & $2 \mathrm{~b}$ & 0 & 7,50 \\
$4 \mathrm{a}$ & $3 \mathrm{~b}$ & 0 & 11,25 \\
$5 \mathrm{a}$ & $4 \mathrm{~b}$ & 0 & 15,00 \\
$6 \mathrm{a}$ & $5 \mathrm{~b}$ & 25 & 0 \\
$7 \mathrm{a}$ & $6 \mathrm{~b}$ & 25 & 3,75 \\
$8 \mathrm{a}$ & $7 \mathrm{~b}$ & 25 & 7,50 \\
$9 \mathrm{a}$ & $8 \mathrm{~b}$ & 25 & 11,25 \\
$10 \mathrm{a}$ & $9 \mathrm{~b}$ & 25 & 15,00 \\
$11 \mathrm{a}$ & $10 \mathrm{~b}$ & 50 & 0 \\
$12 \mathrm{a}$ & $11 \mathrm{~b}$ & 50 & 3,75 \\
$13 \mathrm{a}$ & $12 \mathrm{~b}$ & 50 & 7,50 \\
$14 \mathrm{a}$ & $13 \mathrm{~b}$ & 50 & 11,25 \\
$15 \mathrm{a}$ & $14 \mathrm{~b}$ & 50 & 15,00 \\
$16 \mathrm{a}$ & $15 \mathrm{~b}$ & 100 & 0 \\
$17 \mathrm{a}$ & $16 \mathrm{~b}$ & 100 & 3,75 \\
$18 \mathrm{a}$ & $17 \mathrm{~b}$ & 100 & 7,50 \\
$19 \mathrm{a}$ & $18 \mathrm{~b}$ & 100 & 11,25 \\
$20 \mathrm{a}$ & $19 \mathrm{~b}$ & 100 & 15,00 \\
$21 \mathrm{a}$ & $20 \mathrm{~b}$ & 200 & 0 \\
$22 \mathrm{a}$ & $21 \mathrm{~b}$ & 200 & 3,75 \\
$23 \mathrm{a}$ & $22 \mathrm{~b}$ & 200 & 7,50 \\
$24 \mathrm{a}$ & $23 \mathrm{~b}$ & 200 & 11,25 \\
$25 \mathrm{a}$ & $24 \mathrm{~b}$ & 200 & 15,00 \\
$26 \mathrm{a}$ & $25 \mathrm{~b}$ & $26 \mathrm{~b}$ & $\mathrm{Tabela} 1)$ \\
\hline
\end{tabular}




\subsection{Avaliação dos tratamentos}

\subsubsection{Análises morfológicas}

Após os procedimentos para indução de calos, as avaliações bioquímicas, morfológicas externas e internas foram efetuadas em dois períodos distintos de cultivo (21 e 31 dias) sendo os parâmetros de avaliação foram idênticos para as duas etapas analisadas.

Para cada tratamento, utilizou-se 5 placas de Petri com 20 calos, totalizando 100 calos para cada concentração utilizada em cada período. Após 21 e 31 dias de cultivo, os calos foram analisados quanto ao desenvolvimento, onde se considerou o tamanho, a friabilidade e as características visuais externas das estruturas calogênicas. Quanto ao tamanho das estruturas considerou-se o comprimento em centímetros como padrão para as determinações métricas. Os dados obtidos passaram por análise de médias.

A friabilidade e as diferenças organográficas foram avaliadas de forma visual a medida que se destacavam dentro de um tratamento específico, sendo em seguida registradas fotograficamente.

\subsubsection{Estudos anatômicos}

Os calos desenvolvidos nos tratamentos contendo concentrações combinadas de boro e cálcio foram coletados aos 21 e 31 dias e fixados por 48 horas em solução de Karnovski (Karnovski, 1965). Ao todo foram coletados aleatoriamente 5 calos por tratamento.

Em seguida, estas amostras foram levadas a uma bomba a vácuo para a retirada total do ar dos espaços intercelulares.

Depois de infiltradas as amostras foram desidratadas através de soluções alcoólico-etílicas composta de concentrações crescentes (10, 20, 30, 40, 50, 60, 70, 80, 90 e $100 \% \mathrm{~V} / \mathrm{V})$, permanecendo em cada uma delas por 10 minutos.

Uma vez desidratas as amostras foram infiltradas em resina glicol metacrilato da Reichert-Jung®, formando estruturas sólidas regulares. Os blocos resultantes foram 
seccionados a $0,5 \mu \mathrm{m}$ de espessura através de navalhas de aço do tipo $\mathrm{C}$ acopladas a um micrótomo rotativo manual.

Para cada bloco foram confeccionadas aproximadamente 100 lâminas, sendo dispostos oito cortes anatômicos em cada lâmina de vidro, respeitando-se a seqüência natural de corte das estruturas.

Os cortes foram posteriormente corados com azul de toluidina $0,05 \%$ em tampão fosfato e ácido cítrico (Sakai, 1973) por 15 minutos e montados em resina sintética Entellan (Merck) e cobertos com lamínulas de vidro.

As lâminas foram analisadas em microscópio óptico acoplado a câmara fotográfica para captura de imagens, com a devida escala métrica.

\subsubsection{Análises de massa fresca e massa seca}

Após os registros morfológicos externos, estas estruturas foram retiradas do meio de cultura, limpas rapidamente em papel absorvente e levadas para quantificação da massa fresca (MF) em balança analítica. Suas massas foram registradas em gramas e estes dados foram anotados para posterior análise estatística.

Em seguida, os calos foram acomodados em placas de Petri e levados à estufa a uma temperatura de $60 \pm 5^{\circ} \mathrm{C}$. Após 50 horas, houve a estabilização das massas dos calos fato que possibilitou a determinação, em balança analítica, das respectivas massas secas (MS). Esta massa foi registrada em miligramas, sendo estes dados anotados para posterior análise estatística.

\subsubsection{Análises bioquímicas}

3.2.4.1 Determinação dos níveis de prolina (modificado de Bates et al., 1973)

a) Extração 
Foram pesados cerca de $300 \mathrm{mg}$ (material vegetal fresco) de calos de E. urophylla para cada tratamento. Os materiais foram macerados em gral de porcelana em $10 \mathrm{ml}$ de solução de ácidos sulfosalissílico a 3\%. Os extratos foram centrifugados por 900 segundos a uma velocidade de $3.360,70 \mathrm{~g}$.

\subsection{Determinação com reagente de ninidrina ácida}

a) Preparo do reagente

O preparo do reagente foi realizado em um beker, onde adicionou-se

$1,25 \mathrm{~g}$ de ninidrina

$30 \mathrm{ml}$ de ácido acético glacial

$20 \mathrm{ml}$ de ácido fosfórico $6 \mathrm{M}$

Os componentes foram agregados sob agitação até a dissolução e completa homogeneização da solução.

b) Preparo da curva analítica de calibração de prolina

As concentrações padrões de prolina foram usadas em triplicatas para a construção da curva de calibração foram: $0 ; 20 ; 40 ; 60 ; 80 ; 100 ; 120 ; 140 ; 160 ; 180$ e $200 \mathrm{mg}$ de prolina. $\mathrm{L}^{-1}$. De cada padrão, pipetou-se $2 \mathrm{ml}$, em seguida foram adicionados 2 $\mathrm{ml}$ de ninidrina ácida e $2 \mathrm{ml}$ de acético glacial.

Os tubos foram tapados e mantidos em banho fervente por 1 hora sendo posteriormente resfriados em banho de gelo. Prosseguiu-se então à leitura a $520 \mathrm{~nm}$ (nanômetros) em espectrofotômetro obtendo-se a curva analítica de calibração e a equação da reta que melhor se enquadrou aos pontos obtidos.

Procedeu-se então à leitura das amostras, e com a equação obtida mediante a curva de ajuste dos pontos, tornou-se possível a estimativa das concentrações de prolina (em mg de prolina. $\mathrm{g}^{-1}$ de material vegetal fresco) para cada tratamento proposto. 
3.2.4.2 Determinação de carboidratos não-estruturais solúveis totais - Método de Antrona (Yenm \& Willis, 1954)

\subsection{Extração dos carboidratos não-estruturais solúveis totais}

Foram pesadas aproximadamente $500 \mathrm{mg}$ (material vegetal fresco) de calos de $E$. urophylla em todos os tratamentos. A maceração do material procedeu-se em gral de porcelana com a adição de $10 \mathrm{ml}$ de etanol $80 \%$ (V/V).

Esse extrato foi filtrado em papel de filtro Whatman $\mathrm{n}^{\circ} 1$ sendo o volume recolhido mantido em estufa a vácuo a $45^{\circ} \mathrm{C}$, até a evaporação total do álcool (aproximadamente 17h).

Após a evaporação, as amostras foram resuspendidas em $30 \mathrm{ml}$ de água destilada e deionizada.

\subsection{Determinação com reagente de Antrona}

a) Preparo do reagente de Antrona

Para o preparo do reagente de Antrona utilizou-se um erlenmeyer de vidro, onde foram adicionados:

$5 \mathrm{ml}$ de água destilada e deionizada

$45 \mathrm{ml}$ de ácido sulfúrico concentrado

$100 \mathrm{mg}$ de antrona

A solução foi deixada por 30 minutos em temperatura ambiente, sendo agitada ocasionalmente para obter-se a clarificação da mesma.

b) Preparo da curva analítica de calibração de glicose

Foi preparada uma curva analítica de calibração em triplicata com os seguintes padrões de glicose: $0 ; 25 ; 50 ; 75 ; 100 ; 125 ; 150 ; 175$ e $200 \mathrm{mg}$ de glicose. $\mathrm{L}^{-1}$. De cada padrão, pipetou-se $1 \mathrm{ml}$. Em seguida foram adicionados $7 \mathrm{ml}$ do reagente de antrona. 
A solução foi agitada e aquecida em água fervente por $10 \mathrm{~min}$. Após resfriamento em gelo, procedeu-se à leitura a $625 \mathrm{~nm}$ (nanômetros) em espectrofotômetro obtendo-se a curva analítica de calibração e a equação da reta que melhor se adaptou aos pontos obtidos.

Procedeu-se então à leitura das amostras, e com a equação obtida mediante a curva analítica de calibração, foi possível a estimativa da concentração de carboidratos não-estruturais totais (em mg glicose. $\mathrm{g}^{-1}$ de material vegetal fresco) para cada tratamento proposto.

\subsubsection{Quantificação de proteínas totais (Método de Bradford, 1976)}

\subsection{Extração de proteínas}

a) Preparo da solução de extração

Para a, extração de proteínas foram adicionadas em um beker as seguintes soluções:

$4 \mathrm{ml}$ de tampão tris- $\mathrm{HCl}$ com $\mathrm{pH} 6,8$

$1,6 \mathrm{ml}$ de b-mercaptoetanol

$6,4 \mathrm{ml}$ de SDS-10\% (P/V)

$6,4 \mathrm{ml}$ de glicerol

3,2 $\mathrm{ml}$ de DMSO

1-3 g de PVP 40

10,4 $\mathrm{ml}$ de água destilada deionizada.

Posteriormente, a solução foi colocada sob agitação magnética por 45 minutos.

b) Preparo das amostras de calos para posterior quantificação

Amostras de calos de E. urophylla com aproximadamente $500 \mathrm{mg}$ (material vegetal fresco) foram coletadas e maceradas em gral de porcelana com $4 \mathrm{ml}$ da solução de extração para cada tratamento. 
Após a maceração, o material vegetal permaneceu por 60 minutos à temperatura ambiente. Em seguida a mistura foi aquecida até o ponto de fervura por 3 minutos e posteriormente levou-se as amostras até uma cuba de gelo onde se procedeu a queda brusca da temperatura.

Após o resfriamento, as amostras foram centrifugadas por 300 segundos a uma velocidade de $13.444,14 \mathrm{~g}$, obtendo-se desta forma, o extrato bruto. O sobrenadante foi coletado com auxílio de micropipeta e utilizado para a quantificação do teor de proteínas totais.

\subsection{Quantificação de proteínas totais}

a) Preparo da solução estoque de BSA (albumina bovina)

Foram pesados em balança analítica $0,5 \mu \mathrm{g}$ de BSA (albumina bovina). Acresceu-se a esta albumina $1 \mathrm{ml}$ de $\mathrm{NaCl}$ (cloreto de sódio) 0,5 $\mathrm{M}$ em um beker graduado. Em seguida, a solução foi homogeneizada através de um agitador magnético e após a total dissolução dos sais, reservou-se a mistura para utilização em etapa posterior.

b) Preparo da solução de Coomassie Brilliant Blue G 250

Em balão volumétrico de 1 litro, foram dissolvidos $100 \mathrm{mg}$ de Coomassie Brilliant Blue em $50 \mathrm{ml}$ de etanol. A solução foi agitada vigorosamente e posteriormente de maneira cuidadosa foram adicionados $100 \mathrm{ml}$ de ácido fosfórico concentrado. O volume foi completado para 1 litro com água destilada deionizada.

A solução foi posteriormente filtrada em papel de filtro Whatman $n^{\circ} 1$.

c) Preparo da curva analítica de calibração e leitura das amostras

A curva analítica de calibração foi realizada em triplicata com os seguintes padrões: $0 ; 10 ; 20 ; 40 ; 60 ; 80 ; 100 ; 120 ; 140 ; 160 ; 180$ e $200 \mathrm{mg}$ de albumina. $\mathrm{L}^{-1}$. 
Adicionou-se o volume de $500 \mathrm{ml}$ de solução $\mathrm{NaCl}$ (cloreto de sódio) $0,5 \mathrm{M}$, sendo que o volume final foi completado para $5 \mathrm{ml}$ com a solução de Coomassie.

A curva analítica de calibração foi estabelecida a $595 \mathrm{~nm}$ (nanômetros) em espectrofotômetro e com ela obteve-se a equação da reta, através da qual foi possível a determinação do teor de proteínas totais em cada tratamento na forma de $\mathrm{mg}$ de proteínas. $\mathrm{g}^{-1}$ de material vegetal fresco.

Para a quantificação dos teores de proteínas totais nas amostras, adicionou-se $50 \mathrm{ml}$ de amostra a 4,5 $\mathrm{ml}$ de solução de Coomassie e procedeu-se à leitura em espectrofotômetro a $595 \mathrm{~nm}$ (nanômetros).

\subsubsection{Eletroforese de proteínas solúveis totais em gel de poliacrilamida (Alfenas et al., 1991)}

\subsection{Géis para eletroforese}

a) Preparo do gel de corrida a $10 \%$

Iniciou-se o preparo do gel de corrida adicionando-se em uma proveta graduada as seguintes soluções:

$7 \mathrm{ml}$ de solução de acrilamida a $10 \%$

$10 \mathrm{ml}$ de Tampão Tris $\mathrm{pH} 8,8$

2,5 $\mathrm{ml}$ de água destilada deionizada

$15 \mathrm{ml}$ de TEMED

$330 \mathrm{ml}$ de solução de persulfato de amônio a $10 \%$

Esta solução foi agitada até a completa homogeneização dos componentes.

b) Gel de separação a 3\%

O gel de separação foi preparado em uma proveta graduada adicionando-se as seguintes soluções: 
$1 \mathrm{ml}$ de solução de acrilamida a $10 \%$

3,3 ml de Tampão Tris pH 6,8

$2 \mathrm{ml}$ de água destilada deionizada

$15 \mathrm{ml}$ de TEMED

$200 \mathrm{ml}$ de solução de persulfato de amônio a 10\%

Esta solução foi agitada até a completa homogeneização dos componentes.

c)Tampão de Corrida do Gel (concentrado)

Para a formulação do tampão de corrida foram medidos em balança analítica:

$57,6 \mathrm{~g}$ de Glicina

12,6 g de Trisma-Base.

Em seguida, em uma proveta graduada para 1 litro, adicionou-se água destilada deionizada até completar o volume. Em seguida, esta solução foi mantida sobre refrigeração $\left(5-8^{\circ} \mathrm{C}\right)$ até a utilização em etapa posterior.

O tampão foi diluído 4 vezes para a utilização futura na cuba de corrida de eletroforese. Esta diluição foi realizada em água destilada deionizada e acrescentaram-se $10 \%$ do volume total da solução de SDS a $10 \%(\mathrm{P} / \mathrm{V})$.

\subsection{Procedimento para coloração do gel com prata}

a) Solução Fixadora

Foram medidos em proveta graduada:

$400 \mathrm{ml}$ de etanol;

$100 \mathrm{ml}$ de ácido acético glacial;

$500 \mathrm{ml}$ de água destilada deionizada.

Em seguida esta solução foi aplicada sobre o gel por em um período de 12 horas.

b) Solução Incubadora

No preparo da solução incubadora foram adicionados à uma proveta graduada em $250 \mathrm{ml}$, os seguintes componentes:

$17 \mathrm{~g}$ de acetato de sódio. $3 \mathrm{H}_{2} \mathrm{O}$ 
$75 \mathrm{ml}$ de etanol

$1 \mathrm{~g}$ de tiossulfato de sódio

$1,3 \mathrm{ml}$ de solução de glutaraldeído a $25 \%$

O volume foi completo até $250 \mathrm{ml}$ com água destilada deionizada. A solução foi homogeneizada e aplicada sobre o gel por 15 minutos.

c) Lavagem do gel

O gel foi lavado em água destilada deionizada por 3 vezes, sendo que cada lavagem realizada deu-se por um período de 10 minutos.

d) Solução de Nitrato de Prata

Em uma proveta graduada $(250 \mathrm{ml})$ foram adicionados os seguintes elementos para a preparação da solução de nitrato de prata:

$0,25 \mathrm{~g}$ de nitrato de prata

$50 \mathrm{ml}$ de formaldeído

O volume foi completado para $250 \mathrm{ml}$ com água destilada deionizada, sendo a solução foi aplicada sobre o gel e mantida sobre o mesmo por 20 minutos.

e) Solução de Revelação

A solução de revelação do gel foi preparada misturando-se os seguintes componentes em uma proveta graduada para $250 \mathrm{ml}$ :

$6,25 \mathrm{~g}$ de carbonato de sódio

$25 \mathrm{ml}$ de formaldeído.

O volume foi completo com água destilada deionizada até o volume total da proveta, ou seja, $250 \mathrm{ml}$. Em seguida, esta solução foi aplicada sobre o gel por aproximadamente 35 minutos, ou até que as bandas protéicas começassem a apareçer.

f) Solução de Parada ("Stop") 
Em uma proveta graduada para $250 \mathrm{ml}$, a composição da solução de parada deuse da seguinte forma:

\section{3,65g de sódio-EDTA}

água destilada deionizada até completar o volume da proveta.

A solução foi homogeneizada e aplicada sobre o gel por 10 minutos. Após este período o gel foi submetido a lavagem em água corrente por 1 hora.

Após a confecção e polimerização do gel de poliacrilamida, este foi levado à cuba de corrida de eletroforese, a qual foi preenchida com o tampão de corrida. As amostras foram adicionadas nos poços formados no gel espaçador e a corrida foi realizada em geladeira, utilizando fonte para eletroforese (Pharmacia EPS 300), com corrente elétrica de $75 \mathrm{~mA}$, por um período de aproximadamente 3 horas.

Finalizada a corrida do gel, este foi retirado da cuba e imediatamente imerso em solução fixadora, por 12 horas, como procedimento para iniciar o processo de revelação do gel.

A seguir, foi aplicada uma série de soluções sobre o gel, que constituem o Método de coloração com Prata.

Após este procedimento, o gel foi fotografado, filmado e analisado através do software Kodak Digital Science 1D (Kodak®).

\subsubsection{Análise estatística dos dados}

Realizou-se a análise de variância segundo Pimentel Gomes (1990) considerando o delineamento inteiramente casualizado no esquema fatorial 5 x 5 com uma testemunha adicional e com três repetições. Os tratamentos constaram de 5 concentrações distintas de boro $\left(0,25,50100\right.$ e $\left.200 \mu \mathrm{M} . \mathrm{L}^{-1}\right)$ e 5 concentrações de cálcio $(0,3.25,7.50,11.25$ e $15 \mathrm{mM} . \mathrm{L}^{-1}$ ) em dois períodos distintos, 21 e 31 dias. Posteriormente, foi realizada a 
partição dos efeitos principais e da interação em componentes de regressão e os resultados quando significativos foram expressos em curvas. 


\section{RESULTADOS E DISCUSSÃO}

\subsection{Morfologia externa}

\subsubsection{Considerações gerais}

De acordo com os dados obtidos pode-se observar diferenças no tamanho das estruturas, na presença ou na ausência de raízes, na conformação estrutural (aspecto gelatinoso; estrutura globular na superfície dos calos; na friabilidade e na incidência ou ausência de pigmentos - oxidações e antocianinas).

Os aspectos morfológicos externos de calos de E. urophylla cultivados in vitro por 21 dias em meio N7 modificado com diferentes concentrações de cálcio e boro podem ser visualizados na Figura 1, enquanto a Figura 2 apresenta detalhes de algumas estruturas morfológicas identificadas. A Figura 3 mostra as imagens de calos cultivados in vitro por 31 dias.

De acordo com Sattler \& Rutishauser (1997), a morfologia é a investigação da forma e/ou a estrutura da planta e pode ser interpretada como a formato externo, ou de acordo com Bell (1991), como um instrumento para compreender a forma e a estrutura em todos os níveis organizacionais, isto é, a forma e a estrutura da planta inteira, órgãos, tecidos, células organelas celulares e moléculas. Portanto, a morfologia lato sensu inclui a anatomia e a bioquímica estrutural.

A preocupação com este aspecto dentro do estudo deve-se a importância da morfologia em estudos fisiológicos. A fisiologia vegetal estuda o funcionamento das atividades das plantas e os fatores que influenciam seu metabolismo, como minerais, hormônios e genes. Sendo assim, Sattler \& Rutishauser (1997) afirmam que da mesma 

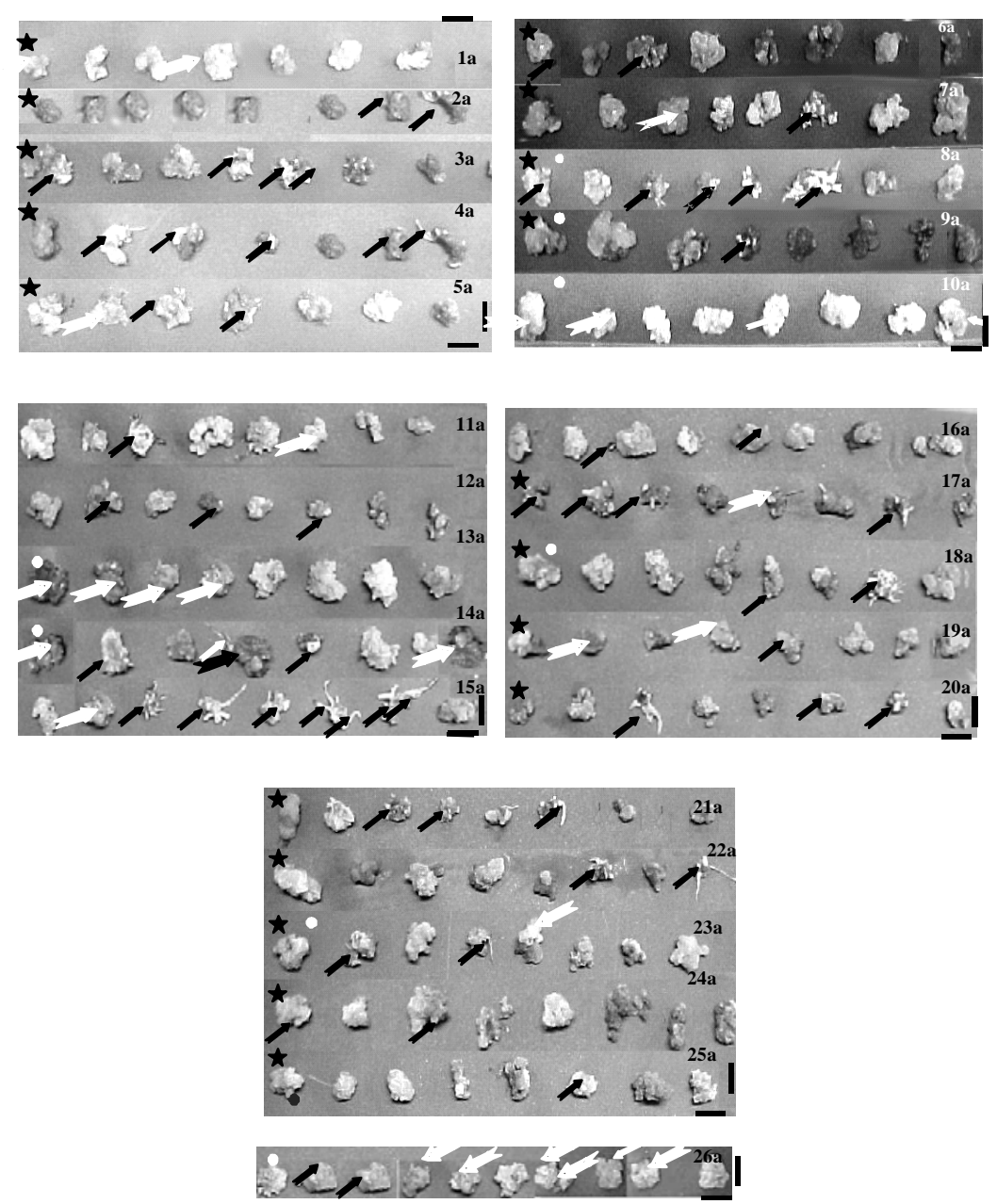

Figura 1 - Morfologia externa de calos de E. urophylla cultivados in vitro por 21 dias em meio N7 (Simola, 1985) modificado com concentrações combinadas de boro e cálcio. Os números seguidos de letras nas linhas representam os tratamentos correspondentes (1a-26a, Tabela 2). As setas brancas indicam a presença de antocianinas. As setas pretas apontam a presença de raízes. Os círculos brancos na linha, mostram a presença de estruturas globulares na superfície dos calos. As estrelas na linha representam os tratamentos com oxidação. Barras $=1 \mathrm{~cm}$ 

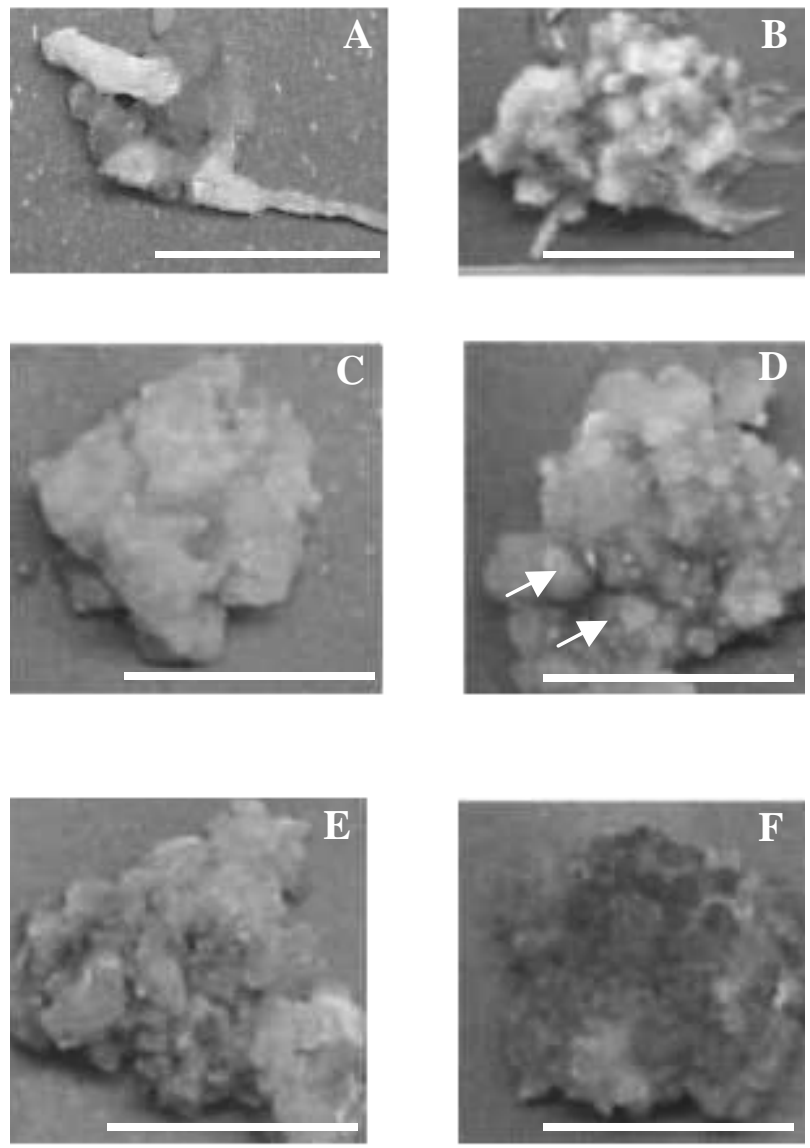

Figura 2 - Detalhes da morfologia externa de calos de E. urophylla cultivados in vitro por 21 dias em meio N7 (Simola, 1985) modificado com concentrações combinadas de boro e cálcio. A) Calo com presença de raízes ligadas de forma frágil com a estrutura; B) Calo com presença de raízes ligadas de forma coesa a estrutura C) Aspecto gelatinoso do calo; D) Estruturas globulares na superfície do calo (setas); E) Calo friável com presença de oxidação; F) Calo com presença de antocianinas. Barras $=1 \mathrm{~cm}$ 


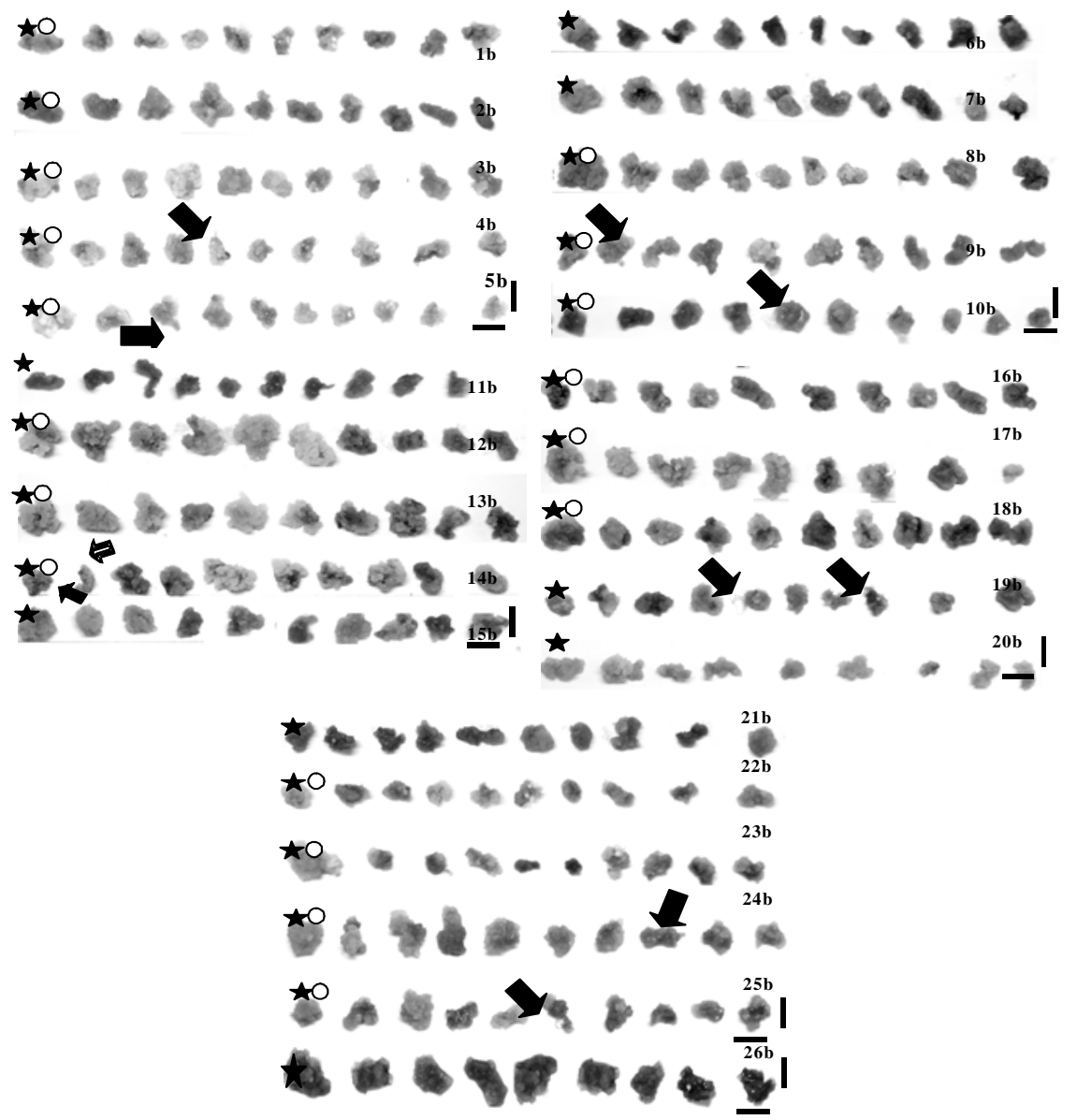

Figura 3 - Morfologia externa de calos de E. urophylla cultivados in vitro por 31 dias em meio N7 (Simola, 1985) modificado com concentrações combinadas de boro e cálcio. Os números seguidos de letras nas linhas representam os tratamentos correspondentes (1b-26b, Tabela 2). As setas pretas pequenas indicam a presença de antocianinas. As setas pretas grandes apontam a presença de raízes.Os círculos brancos na linha, mostram a presença de estruturas globulares na superfície dos calos. As estrelas na linha representam os tratamentos com oxidação. Barras $=1 \mathrm{~cm}$ 
forma que estes componentes afetam os processos fisiológicos as formas morfológicas também são influenciadas por estes fatores, modificando os modelos integrais das plantas. Assim concordando com as ponderações dos autores podemos inferir que as manifestações de sintomas visuais relacionam-se com modificações em nível celular, bioquímico e metabólico.

A avaliação visual, baseada em sintomas morfológicos em folhas e raízes são procedimentos muito utilizados para diagnosticar anomalias minerais, principalmente em cultivos no campo e em casas de vegetação. Em culturas in vitro, a diagnose de sintomas visuais causados por distúrbios minerais em folhas de Eucalyptus também tem sido avaliadas como forma de otimizar as informações que posteriormente serão extrapoladas para grandes áreas de cultivo. Contudo, o registro deste tipo de análise para calos cultivados sob concentrações inadequadas de nutrientes minerais é pouco comum.

Trevizam (2001) avaliou morfologicamente calos de E. urophylla cultivados com concentrações distintas de boro e verificou diferenças marcantes entre os tratamentos e também relatou algumas inter-relações entre a morfologia dos calos, as análises bioquímicas realizadas e as concentraçõess de boro empregadas.

\subsubsection{Tamanho dos calos}

O tamanho médio dos calos nos dois períodos de cultivo (21 e 31 dias), foi registrado em centímetros através do gráfico presente na Figura 4.

Observando a Figura 4, notou-se que de maneira geral os calos analisados aos 21 dias de cultivo in vitro apresentaram maiores diferenças estruturais quando comparados aos calos que permaneceram por mais tempo em meio de cultura (31 dias).

Constatou-se através desta avaliação que o cultivo prolongado dos calos ocasionou um retrocesso nos processos de desenvolvimento. Após 21 dias de cultivo in vitro, notou-se que os calos formados iniciaram um processo de oxidação e o crescimento e formação de novas raízes foi reduzida bruscamente, sendo que aos 31 dias, se verificaram externamente poucos processos rizogênicos. O esgotamento mineral do meio de cultura, pode ter levado os calos a uma deficiência crônica de um ou mais 
nutrientes essenciais ao desenvolvimento e metabolismo celular, retardando o processo de crescimento e desenvolvimento radicular.

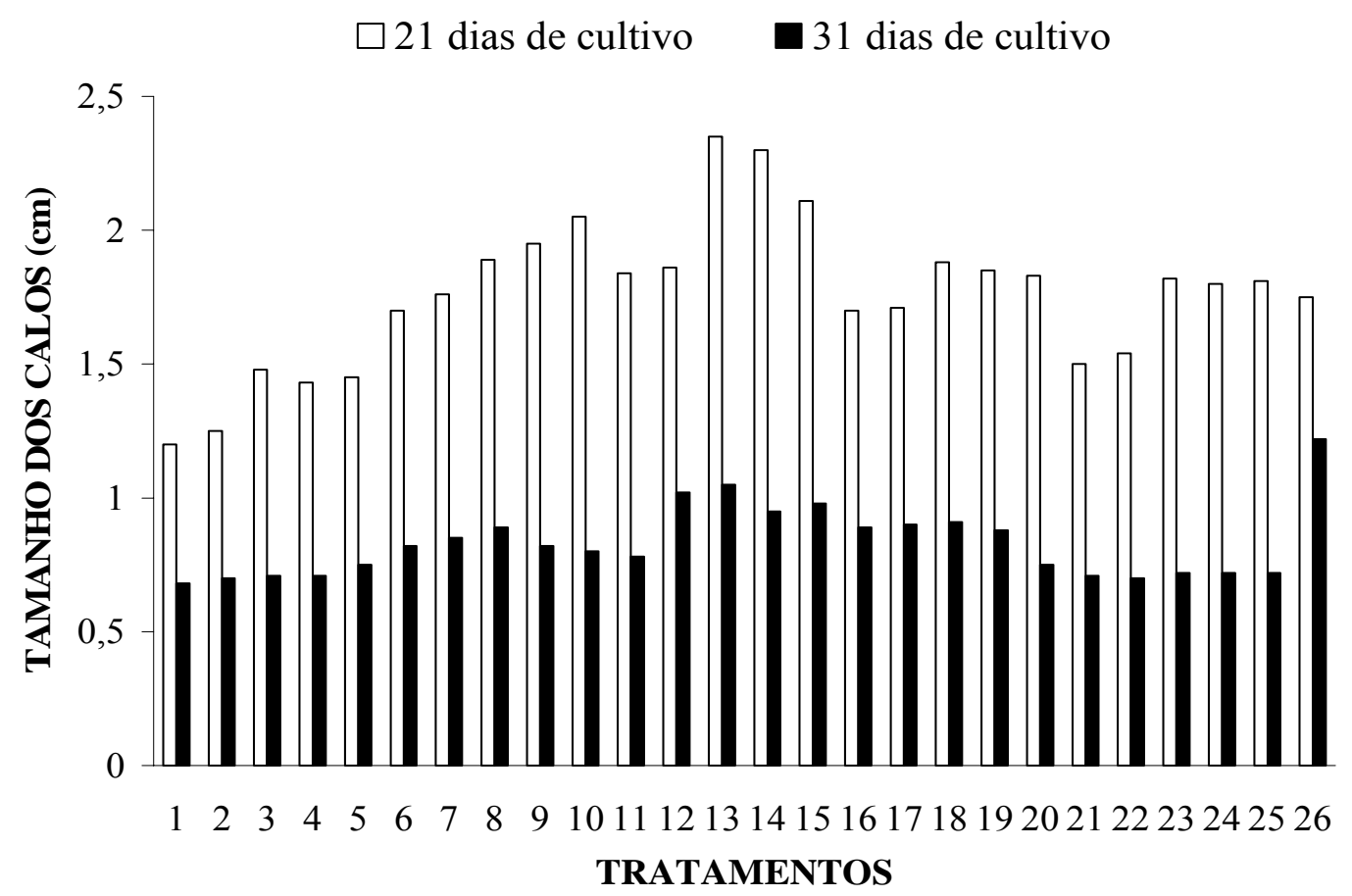

Figura 4 - Tamanhos médios dos calos (cm) de Eucalyptus urophylla cultivados in vitro em meio N7 modificado com concentrações distintas de boro e cálcio (tratamentos T1 à T26, Tabela 2) em dois períodos distintos de cultivo (21 e 31 dias)

De acordo com Guerra et al. (1999) a exposição de materiais vegetais cultivados in vitro por períodos determinados em meio de cultura, pode interferir em seu desenvolvimento. Correia (1993) ao estudar o desenvolvimento de Eucalyptus spp. in vitro mostrou que o crescimento destas culturas caracteriza-se por 6 fases, as quais 
apresentam um crescimento logarítmico ou exponencial, todavia o esgotamento do meio de cultura é um fator limitante para a avaliação da cultura em estudo.

Esta diminuição em tamanho das estruturas calogênicas podem ter sido desencadeadas pela perda de água das células para o meio de cultura ou por processos de autólise, caracterizando um efeito de proteção mediante uma situação de estresse.

Diversos fatores como o genótipo, o meio de cultura, condições físicas e do meio são relatadas como responsáveis por afetar a morfogênese in vitro e o desenvolvimento das plantas. Borgatto et al. (2002) testando vários níveis de cálcio, potássio e magnésio em Chrysanthemum morifolium, verificaram que a calogênese e o crescimento dos calos foram influenciados negativamente pelo tempo de cultivo in vitro principalmente em meios com baixas concentrações de cálcio.

Para a variável tamanho de calos, os dados indicaram aos 21 dias que a concentração com $50 \mu \mathrm{M} . \mathrm{L}^{-1}$ de boro e $7,5 \mu \mathrm{mM} \cdot \mathrm{L}^{-1}$ de cálcio foi a mais eficiente, enquanto aos 31 dias de cultivo o meio padrão apresentou o melhor resultado (Figura 4).

Observando o gráfico representado pela Figura 4 verificou-se ainda que independente da concentração de cálcio empregada, ao se utilizar 25 e $50 \mu \mathrm{M} . \mathrm{L}^{-1}$ de boro no meio de cultura houve uma melhor resposta dos calos a esta concentração em relação as demais concentraçõess empregadas no ensaio. Trevizam (2001) testando concentraçõess de boro em cultivos in vitro de E. urophylla relatou também um desenvolvimento mais satisfatório de calos nesta mesma concentração, ou seja $50 \mu{\mathrm{M} . \mathrm{L}^{-}}^{-}$ ${ }^{1}$. Desta forma, estes dados podem inferir que o meio de cultura contendo a concentração $50 \mu \mathrm{M} . \mathrm{L}^{-1}$ de boro foi o que mais promoveu o crescimento dos calos aos 21 dias, enquanto para 31 dias o melhor desenvolvimento ocorreu com o meio padrão (N7 Simola, 1985). O fato de períodos de cultivo mais prolongados se adaptarem melhor ao médio padrão, pode ser interpretado como a existência de um balanço nutricional adequado capaz de suportar o crescimento de calos desta espécie mesmo quando se apresentam situações adversas de cultivo.

Verificou-se ainda que os calos cultivados, em meio com concentração 0 mM.L ${ }^{-1}$ de cálcio combinados com 25, 50, 100 e $200 \mu \mathrm{M} . \mathrm{L}^{-1}$ de boro, se desenvolveram melhor 
do que na ausência completa destes dois nutrientes. Estes dados denotam a interferência do micronutriente no tamanho de calos de E. urophylla e na sua capacidade de remediar as deficiências do cálcio.

Estas observações também foram relatadas em estudos realizados por Bonilla et al. (1995) em espécies de Synechococcus onde os autores também verificaram que a suplementação de um meio de cultura deficiente em cálcio com boro foi capaz de restaurar parcialmente a capacidade de crescimento da espécie. Estes estudos sugeriram um provável papel sinergístico entre o micro e o macronutriente indicando a capacidade do boro em recuperar organismos (cianobactérias) submetidos à deficiências por cálcio. De acordo com Ramón et al. (1990) a quantidade e disponibilidade de um dos nutrientes (cálcio ou boro) podem interferir na distribuição e também no requerimento do outro nutriente para alcançar um índice de crescimento ótimo da planta.

\subsection{Morfologia interna}

\subsubsection{Considerações gerais}

Embora o estudo de características da morfologia interna em cultura de células e tecidos vegetais seja um procedimento padrão, a análise destas características em calos relacionadas a parâmetros nutricionais tornou-se ferramenta obrigatória apenas nas últimas décadas. Estes procedimentos de análise visam o entendimento dos mecanismos celulares e metabólicos a que os organismos vegetais são submetidos ao sofrerem variações nas concentrações minerais em meio de cultura.

Diante destes fatos, as análises visuais comparadas com alguns parâmetros marcantes da anatomia interna foram descritas neste estudo buscando uma melhor compreensão para as formas de atuação do boro e do cálcio em calos de E.urophylla cultivado in vitro.

Os dados da morfologia interna foram registrados através da Figuras 5, 6, 7, 8, 9, $10,11,12,13,14,15$ e 16 e relacionam as características da morfologia interna comparando dados da morfologia externa (Figuras 1, 2 e 3). 
Aos 21 dias de cultivo in vitro, notou-se que na omissão do micronutriente, independente das concentrações de cálcio, ocorreu uma coloração mais forte dos cortes histológicos dos calos quando comparado as mesmas combinações no período de 31 dias.

No período de 31 dias, a deficiência dos íons boro e cálcio poderia ser apontada como responsável pelas modificações nas ligações moleculares do calo, fato que possivelmente interferiu na coloração dos cortes. Moraes et al. (2002) também relacionaram a deficiência por boro e a coloração menos intensa ao azul de toluidina em xilemas de caules de seringueira (Hevea spp.).

Considerando que a metodologia utilizada foi idêntica para os dois períodos de cultivo, poderíamos supor que para estas concentrações existiriam reações distintas do material vegetal em relação ao corante azul de toluidina, ocasionada provavelmente por mudanças metabólicas e/ou celulares decorrentes das concentrações minerais aliadas ao fator tempo.

Outro fator relevante observado em calos cultivados por 21 dias foi a organização celular com a formação de meristemóides e raízes, ao passo que tempos mais longos de cultivo determinaram estruturas compostas de células meristemáticas diferenciadas em estruturas vasculares.

Nas concentrações de $50 \mu \mathrm{M} . \mathrm{L}^{-1}$ de boro combinado com 7,5, 11,25 e 15 mM.L ${ }^{-1}$ de cálcio e $100 \mu \mathrm{M} . \mathrm{L}^{-1}$ de boro combinado com 7,5 e 11,25 mM.L ${ }^{-1}$ de cálcio do meio de cultura para calos de E urophylla cultivados por 21 dias, os meristemóides apresentaram arranjos organizados compostos de células pequenas dispostas concentricamente, com aspecto isodiamétrico, sem vacúolos, com núcleos densamente corados e elevada relação núcleo citoplasmática (RPN), (Figura 5). Ho \& Vasil (1983) classificam estes centros meristemáticos como embrióides. Em contrapartida considerando os resultados obtidos poderíamos supor que a presença destes centros meristemáticos indicariam processos morfogenéticos capacitados para a formação de raízes e/ou pré-embriões somáticos. 
Como não foram verificados embriões somáticos durantes os dois períodos de cultivo, supõem que concentrações combinadas de boro e cálcio possuem a capacidade de interferir na polaridade celular. A presença de intensas divisões celulares e a grande capacidade rizogênica dos calos mantidos in vitro por 21 dias, nos permitiram inferir que houve predominância da polarização da base dos meristemas, caracterizando a formação de raízes. Já aos 31 dias, a diferenciação das estruturas radiculares não foram visualmente identificadas.

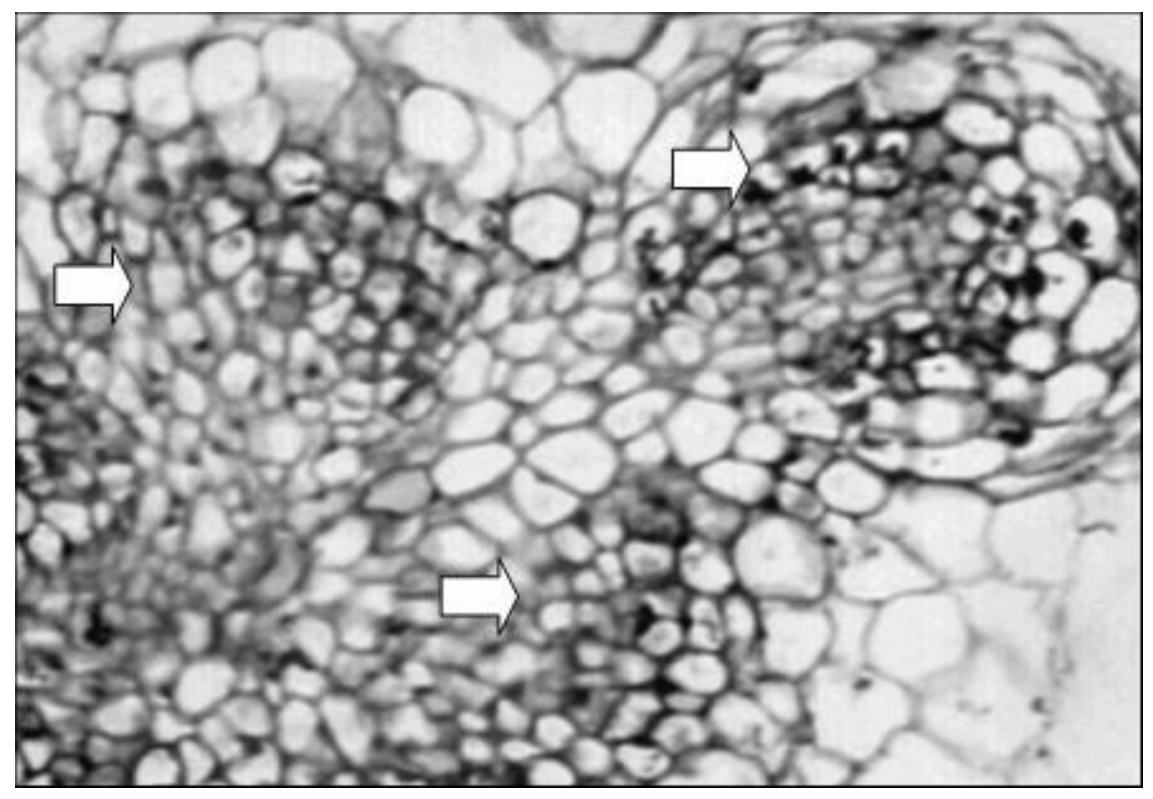

Figura 5 - Aspecto geral dos meristemóides apresentados aos 21 dias de cultivo in vitro em calos de E. urophylla. As setas indicam a presença de células pequenas e organizadas, com formatos isodiamétricos, intensas divisões nucleares e elevada relação núcleo citoplasmática

Os cortes histológicos de calos E. urophylla avaliados aos 31 dias, apresentaram 2 tipos de diferenciação em combinações distintas. 
A primeira foi verificada nas conbinações $25 \mu \mathrm{M} . \mathrm{L}^{-1}$ de boro com todas as concentrações de cálcio, $50 \mu \mathrm{M} . \mathrm{L}^{-1}$ de boro com 3,75 e $15 \mathrm{mM} . \mathrm{L}^{-1}$ de cálcio, $100 \mu \mathrm{M} . \mathrm{L}^{-1}$ de boro com $0,3,75,7,5 \mathrm{mM} . \mathrm{L}^{-1}$ de cálcio e $200 \mu \mathrm{M} . \mathrm{L}^{-1}$ de boro com $0,3,75$, e 7,5 mM.L ${ }^{-1}$ de cálcio (Figura 6) e a segunda pode ser observada nas combinações $100 \mu \mathrm{M} . \mathrm{L}^{-1}$ de boro com 11,25 e 15 mM.L ${ }^{-1}$ de cálcio e $200 \mu \mathrm{M} . \mathrm{L}^{-1}$ de boro com 11,25 e $15 \mathrm{mM} . \mathrm{L}^{-1}$ de cálcio (Figura 7)

Os calos que apresentaram o primeiro tipo de diferenciação (Figura 6) apresentaram estruturas com células de aspecto meristemático, porém arranjadas de forma distinta ao observado para o período de cultivo de 21 dias (Figura 5). No maior período de cultivo essas estruturas se mostraram organizadas em estratos com células alongadas, com núcleos aparentes e uma diferenciação de sistema vascular sem a formação convencional de raízes.

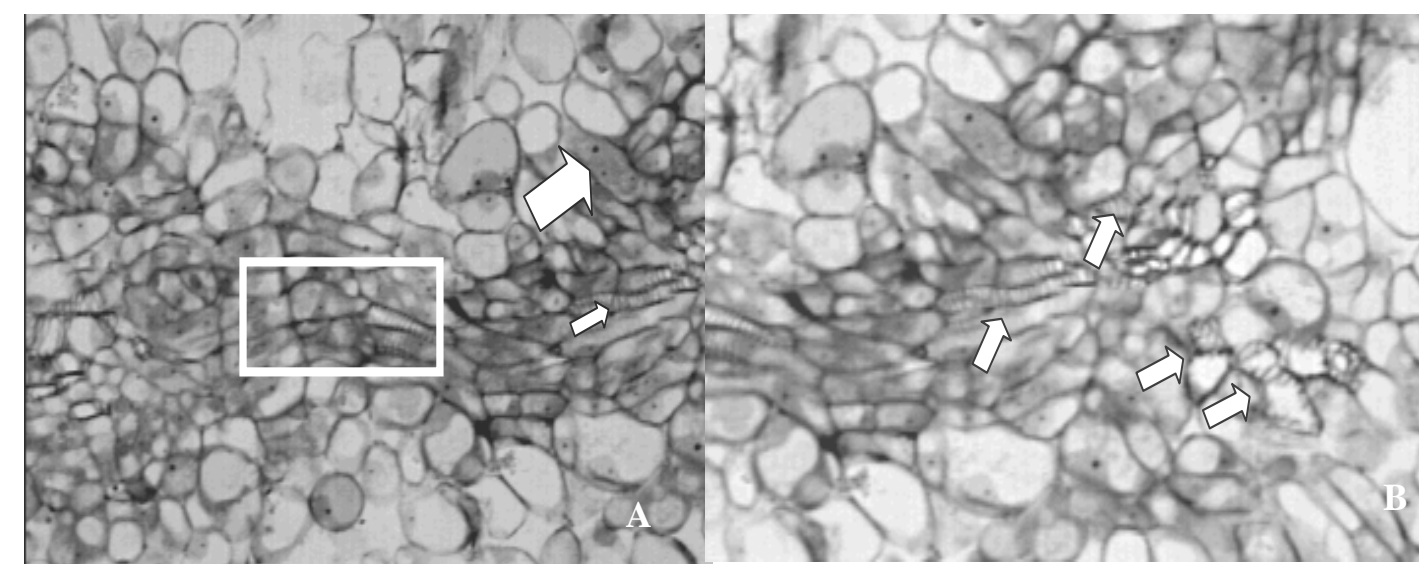

Figura 6 - Aspecto geral das regiões em diferenciação dos meristemóides apresentados aos 31 dias de cultivo in vitro em calos de E. urophylla. A) células com baixa RPN, com diferenciação de sistema fundamental, com formas alongadas (em detalhe), núcleos proeminentes com indicação de divisão celular (seta branca grande) e diferenciação de sistema vascular (seta 
branca pequena); B) Detalhe elementos vasculares do xilema (em vista longitudinal) formados isoladamente nos calos (setas brancas)

A diferenciação de elementos vasculares também foi visualizada em calos de $E$. urophylla, avaliados aos 31 dias de cultivo, nas combinações $100 \mu \mathrm{M} . \mathrm{L}^{-1}$ de boro com 11,25 e 15 mM.L $\mathrm{L}^{-1}$ de cálcio e $200 \mu \mathrm{M} . \mathrm{L}^{-1}$ de boro com 11,25 e $15 \mathrm{mM} . \mathrm{L}^{-1}$ de cálcio (Figura 7).

Notou-se que nestes tratamentos os meristemóides apresentavam um formato regular (concêntrico) semelhante ao visualizado aos 21 dias (Figura 5), no entanto, o fator diferencial nestas estruturas deu-se pelo desenvolvimento de vasos condutores, especificamente, elementos de vaso (xilogênese) sem a ligação com uma forma convencional de um órgão. Verificou-se também que os cortes dos vasos deram-se de forma longitudinal, enquanto a estrutura meristemática mostrava um corte transversal.

Observou-se que as células da periferia do calo eram isodiamétricas e com relação núcleo/plasmática alta, revelando elevada atividade meristemática e por tanto muito indiferenciadas, ao passo que as centrais apresentam-se alongadas com reforço de lignina, indicando elevado índice de diferenciação para a formação de elementos de vaso (Figura 7).

Sabe-se que as células meristemáticas quando param de se dividir, passam por um processo de diferenciação transformando-se em células de tecidos diferenciados, que compõem o corpo vegetal. O xilema e floema em estágio primário de desenvolvimento, se originam a partir do tecido meristemático do procâmbio, sendo classificados como tecidos complexos, uma vez que são os últimos a se diferenciar e contém células de mais de um tipo de tecido (Esau, 1998). A Figura 7 B mostra vasos condutores se diferenciando apartir do meristemóide, no enatnto estudos posteriores derão ser 
realizados uma vez que o plano de corte dos calos de E. urophylla, pode ter interferido nas análises dos cortes histológicos.

Embora a literatura relacione o boro e o cálcio com diversas atuações celulares, não se verificou qualquer descrição da correlação direta da interação destes dois nutrientes na gênese de elementos vasculares.

A atuação destes íons em E. urophylla está relacionada principalmente com a formação e alongamento do sistema radicular, no entanto Lewis (1980) afirma que a ação primária do boro ocorre na diferenciação do xilema. Da mesma forma Moraes et al. (2002), ao estudarem a relação entre a flexibilidade do caule de seringueira com a carência de boro, constataram que os elementos do xilema recém-formados possuíam paredes primárias mais finas nas amostras de plantas com sintomas de deficiência causadas pelo micronutriente. Este aspecto também pode ser relacionado com a coloração menos intensa dos cortes histológicos provenientes de calos cultivados com concentraçõess deficientes de boro e cálcio cultivados por 31 dias.

Neste estudo não foi possível verificar a relação dos nutrientes minerais com as paredes dos vasos condutores. No entanto, admite-se que aos 31 dias a interação do boro com o cálcio por meio das combinações $100 \mu \mathrm{M} . \mathrm{L}^{-1}$ de boro com 11,25 e 15,0 mM.L $\mathrm{L}^{-1}$ de cálcio e $200 \mu \mathrm{M} . \mathrm{L}^{-1}$ de boro com 11,25 e 15,0 mM.L $\mathrm{L}^{-1}$ de cálcio, foram responsáveis pelo desenvolvimento precoce de vasos de xilema. 

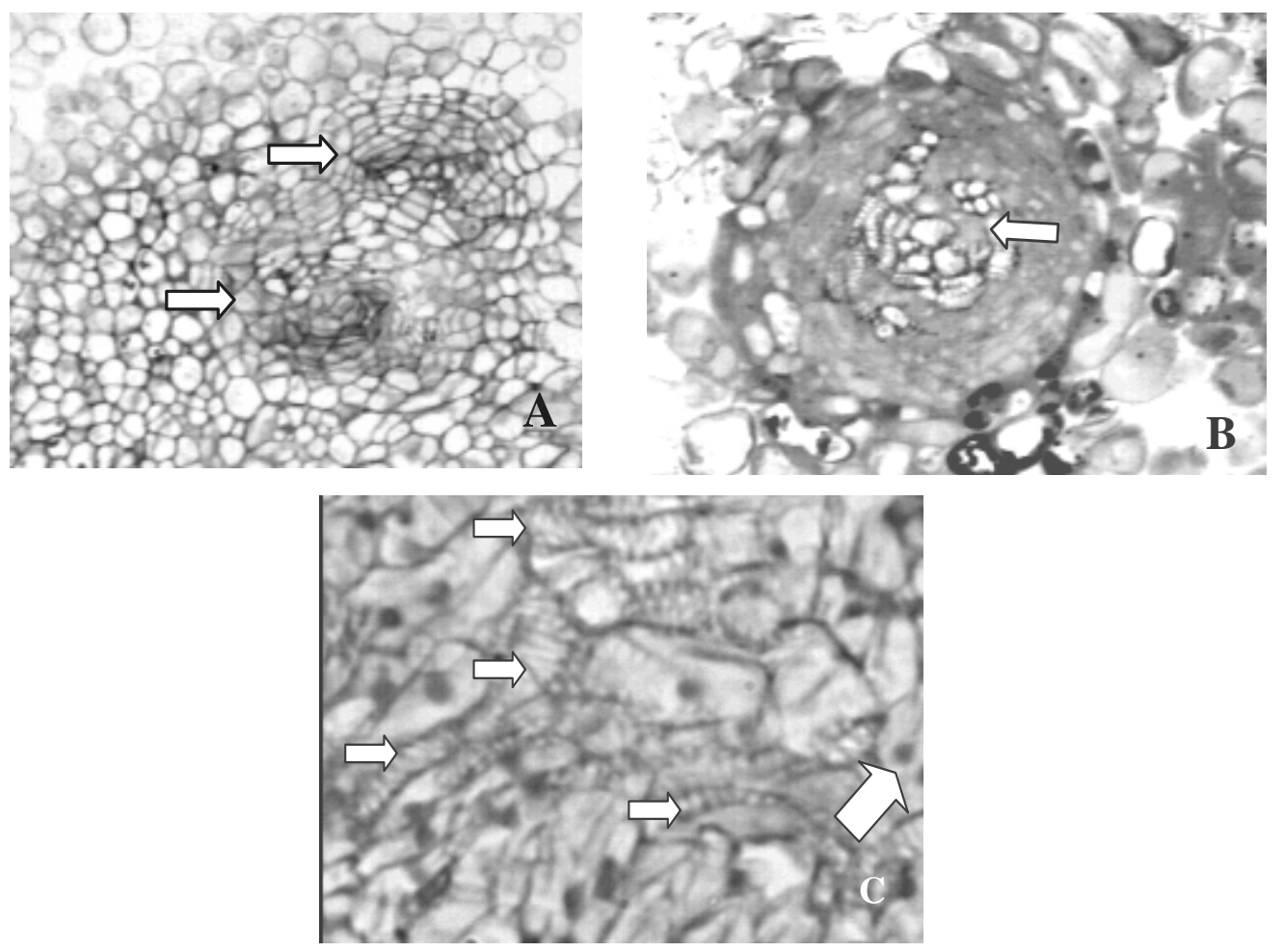

Figura 7 - Aspecto geral de meristemóide com forma circular visualizado aos 31 dias em combinações especificas de boro e cálcio. A) Conformação circular do meristemóide (seta); B) diferenciação do xilema no centro do meristemóide (seta); C) Detalhe dos xilemas (setas brancas pequenas) e dos núcleos proeminentes com presença de divisão celular (seta branca grande) 


\subsubsection{Morfologia interna associada a morfologia externa}

\subsubsection{Rizogênese}

Analisando as Figuras 1, 2A, 2B e 3, notamos processos rizogênicos em diversos tratamentos para os dois períodos de cultivo. Desta forma, observou-se que o desenvolvimento de estruturas rizogênicas foi inversamente proporcional ao tempo de cultivo in vitro, ou seja, no período de 21 dias a formação de raízes foi mais evidenciada, enquanto que em calos mantidos em cultura por 31 dias a presença de raízes aparentes na superfície dos calos foi pouco observada.

Komatsu (1995) ao estudar a morfogênese de Phylostachys bambusoides relacionou a formação de raízes com calos do tipo amarelo globoso. No entanto, diante do presente estudo não se verificou este tipo de correlação em calos de Eucalyptus urophylla. Este fato provavelmente deve-se a distinção evolutiva e filogenética entre as espécies e a forma de cultivo, uma vez que as estruturas foram mantidas em cultivo em meios de cultura diferenciados, respectivamente MS (Murashige \& Skoog, 1962) e N7 (Simola, 1985).

De acordo com a Figura 1, notou-se que para os calos cultivados in vitro por 21 dias houve a presença de raízes na maioria dos tratamentos, excetuando-se as combinações $0 \mu \mathrm{M} . \mathrm{L}^{-1}$ de boro e $0 \mathrm{mM} \cdot \mathrm{L}^{-1}$ de cálcio, $50 \mu \mathrm{M} \cdot \mathrm{L}^{-1}$ de boro e $7,5 \mathrm{mM} . \mathrm{L}^{-1}$ de cálcio e o meio padrão que não apresentaram o desenvolvimento do órgão. Já nos calos cultivados in vitro por 31 dias (Figura 3) observou-se a presença de raízes apenas em $0 \mu \mathrm{M} . \mathrm{L}^{-1}$ de boro com 11,25 e $15 \mathrm{mM} . \mathrm{L}^{-1}$ de cálcio, $25 \mu \mathrm{M} . \mathrm{L}^{-1}$ de boro com 11,25 e $15 \mathrm{mM} . \mathrm{L}^{-1}$ de cálcio, $100 \mu \mathrm{M} . \mathrm{L}^{-1}$ de boro e $11,25 \mathrm{mM} . \mathrm{L}^{-1}$ de cálcio, $200 \mu \mathrm{M} . \mathrm{L}^{-1}$ de boro com 7,5, 11,25 e 15 mM.L $\mathrm{L}^{-1}$ de cálcio.

De maneira geral. a organogênese pode ser ativada pela otimização das concentrações de auxinas e citocininas no meio de cultura, de acordo com Khang \& Chun (1997), quando a concentração de auxinas é ótima existe o favorecimento da formação de raízes. 
Embora os calos cultivados por 21 dias tenham desenvolvido raízes na maioria dos tratamentos, as conformações destas estruturas em relação a massa de células indiferenciadas foi distinta. Notou-se nas combinações $0 \mu \mathrm{M} . \mathrm{L}^{-1}$ de boro com 3,75, 7,5, 11,25 e $15 \mathrm{mM} . \mathrm{L}^{-1}$ de cálcio e $100 \mu \mathrm{M} . \mathrm{L}^{-1}$ de boro com $0,3,75$ e $15 \mathrm{mM} . \mathrm{L}^{-1}$ de cálcio que as raízes formadas apresentavam ligação frágil com os calos (Figura 2 A), sendo destacadas facilmente da massa de células. Estes dados podem indicar a ausência de conexão do sistema vascular da raiz com o calo, denotando uma provável diferenciação das raízes (rizogênese) diretamente a partir de células parenquimáticas do calo (Figura $8 \mathrm{C}$ ).

De forma distinta, aos 21 dias, as combinações $25 \mu \mathrm{M} . \mathrm{L}^{-1}$ de boro com 7,5 mM.L $\mathrm{L}^{-1}$ de cálcio, $50 \mu \mathrm{M} . \mathrm{L}^{-1}$ de boro com $0 \mathrm{mM} . \mathrm{L}^{-1}$ de cálcio e $100 \mu \mathrm{M} . \mathrm{L}^{-1}$ de boro com 7,5 mM.L ${ }^{-1}$ de cálcio (Figura 2B) mostraram uma ligação entre raízes e calos mais coesa. Este fato foi verificado também em calos cultivados por 31 dias nos seguintes tratamentos: $0 \mu \mathrm{M} . \mathrm{L}^{-1}$ de boro com 11,25 e $15 \mathrm{mM} . \mathrm{L}^{-1}$ de cálcio, $25 \mu \mathrm{M} . \mathrm{L}^{-1}$ de boro com 11,25 e $15 \mathrm{mM} . \mathrm{L}^{-1}$ de cálcio, $100 \mu \mathrm{M} . \mathrm{L}^{-1}$ de boro com 11,25 mM.L ${ }^{-1}$ de cálcio e $200 \mu \mathrm{M} . \mathrm{L}^{-1}$ de boro com 7,5, 11,25 e 15 mM.L ${ }^{-1}$ de cálcio (Figura 8 A e 8 B).

Independentemente das concentrações de boro e dos períodos de análises, verificou-se relação entre a concentração de cálcio e a presença de raízes coesas junto à massa de células. Concentrações de cálcio superiores a 7,5 mM.L ${ }^{-1}$, independente da concentração de boro, foram mais efetivas neste tipo de processo, denotando a provável interferência do macronutriente na formação de raízes conectadas a massa de calos. Comparando estes dados com a anatomia interna dos calos presentes na Figura $8 \mathrm{~A}$ e $8 \mathrm{~B}$, verificamos que as raízes desenvolvidas nestes tratamentos surgiam a partir de divisões celulares internas, conectadas à massa de calos mais compactos ou menos friáveis. Uma maior presença de lignina, promovida pela interação específica do boro e cálcio, também poderia justificar essa ligação das raízes com a massa de calos. No entanto não foram realizadas análises específicas para comprovar essa hipótese.

A Figura $8 \mathrm{C}$, mostrou aos 21 dias de cultivo, para as combinações $0 \mu \mathrm{M} . \mathrm{L}^{-1}$ de boro com 3,75, 7,5, 11,25 e 15 mM.L ${ }^{-1}$ de cálcio, $100 \mu \mathrm{M} . \mathrm{L}^{-1}$ de boro com $0,3,75 \mathrm{e}$ 
$15 \mathrm{mM} . \mathrm{L}^{-1}$ de cálcio a presença de raízes desligadas da massa de calos, que poderiam ter se originado a partir de células mais externas.

Em tratamentos com omissão total de boro e cálcio não existiu a formação de raízes em nenhum dos períodos analisados.
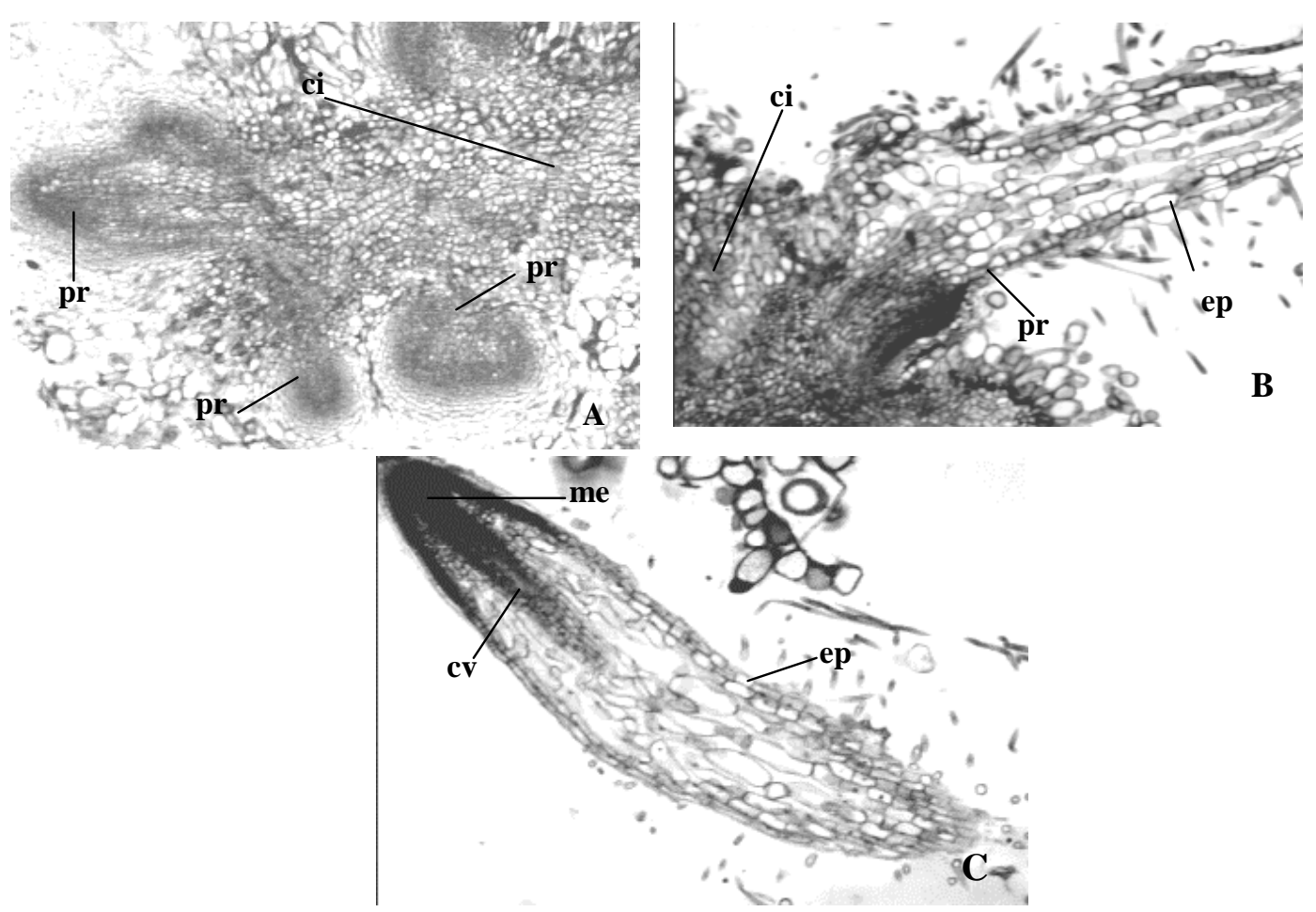

Figura 8 - Formação de primórdios radiculares em cortes longitudinais. A) Presença de raízes em início de formação apresentando desenvolvimento endógeno, denotando uma ligação evidente entre raiz e calo; B) Raiz que rompeu as células internas do calo e despontou na superfície sem perder a conexão inicial; C) Raiz formada com cilindro vascular evidente. pr - primórdio radicular; ci - celulas indiferenciadas do calo; ep - epiderme da raiz; cv - cilindro vascular; me - região meristemática 
Aos 21 dias de cultivo, as raízes apresentaram estruturas compostas por células desestruturadas com paredes rompidas e colapsadas sem diferenciação completa do cilindro vascular nas combinações $0 \mu \mathrm{M} . \mathrm{L}^{-1}$ de boro com 3,75, 7,5, 11,25 e 15 mM.L ${ }^{-1}$ de cálcio, $50 \mu \mathrm{M} . \mathrm{L}^{-1}$ de boro com $0 \mathrm{mM} . \mathrm{L}^{-1}$ de cálcio, $100 \mu \mathrm{M} . \mathrm{L}^{-1}$ de boro com $0 \mathrm{mM} . \mathrm{L}^{-}$ ${ }^{1}$ de cálcio e $200 \mu \mathrm{M} . \mathrm{L}^{-1}$ de boro com $0 \mathrm{mM} . \mathrm{L}^{-1}$ de cálcio. Tais aspectos também foram verificados para o período de cultivo de 31 dias nas combinações $0 \mu \mathrm{M} . \mathrm{L}^{-1}$ de boro com $15 \mathrm{mM} . \mathrm{L}^{-1}$ de cálcio e $50 \mu \mathrm{M} . \mathrm{L}^{-1}$ de boro com $0 \mathrm{mM} . \mathrm{L}^{-1}$ de cálcio.

Essa desestruturação celular provavelmente poderia interferir nas funções fisiológicas e estruturais do órgão (Figura 9). Observou-se também que a conformação das células epidérmicas foi irregular e descontinua sendo inexistente em alguns pontos. Logo abaixo da epiderme, observou-se a presença da endoderme, que se caracterizou pela presença de células arredondadas de coloração mais intensa contornando a maior parte da estrutura, caracterizando um provável espessamento em "U" ou estrias de Caspary (Figura 9 A e 9 B). Este espessamento poderia indicar também a formação de um tecido de sustentação com fibras esclerenquimaticas denotando um envelhecimento precose dos tecidos, porém estas afirmações necessitam um estudo posterior.

A origem endógena das ramificações radiculares ocorreu a partir do periciclo, de forma similar ao observado in vivo. Moraes-Dallaqua et al. (2000) também verificaram estas desestruturações radiculares ao estudarem raízes de feijoeiro submetidas a omissão de boro.

O efeito primário da omissão de boro em raízes é controverso, para Kouchi \& Kumazawa (1975), a cessação da divisão e do alongamento celular são os principais papéis do micronutriente. Já Cohen \& Lepper (1977) consideram que a cessação do alongamento de raízes de abóbora, submetidas à omissão de boro, foi causada pela falta de divisão das células meristemáticas, sugerindo que esse micronutriente atua como um regulador da divisão celular.

Aos 31 dias de cultivo de calos de E. urophylla as limitações nutricionais do meio de cultura podem ter sido determinantes para que os calos só respondessem com a rizogênese sob concentrações mais elevadas de cálcio, ou seja em concentrações 
superiores a $7,5 \mathrm{mM} \cdot \mathrm{L}^{-1}$.

Bolaños et al. (1993) confirmam o papel sinergístico do boro e do cálcio em estudos com cianobactérias e Ramón et al. (1990) afirmam que a quantidade e disponibilidade de um dos nutrientes (cálcio ou boro) poderiam interferir na distribuição e também no requerimento do outro nutriente para que a planta alcance um índice de crescimento global ou em sua forma isolada atuante em tecidos e/ou órgãos.

Desta forma podemos supor que estes nutrientes atuam de maneira conjunta em processos organogênicos.
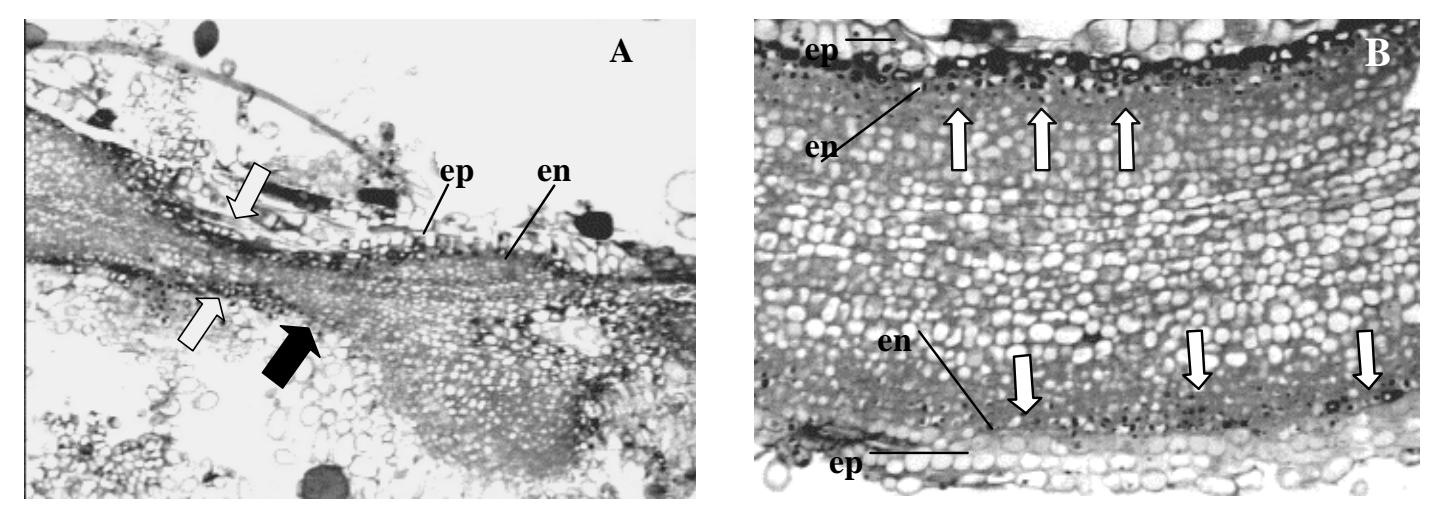

Figura 9 - Aspecto geral de estruturas radiculares presentes nos tratamentos em combinações específicas de cálcio e boro (citadas anteriormente no texto). A) Raiz com conformação desestruturada, apresentando células mais coradas na endoderme (setas brancas) e ausência de células epidérmicas (seta preta); B) Detalhe da região com espessamento de celulas, indicando maior diferenciação (setas). ep - epiderme; en - endoderme

As combinações $25 \mu \mathrm{M} . \mathrm{L}^{-1}$ de boro com $0,3,75,7,5,11,25$ e $15 \mathrm{mM} . \mathrm{L}^{-1}$ de cálcio, aos 21 dias, mostraram raízes com modificações estruturais diversas (Figura 10), no entanto estas concentrações mostraram-se menos destrutivas às raízes, denotando uma formação mais habitual do órgão. Notou-se que predominantemente, as raízes com 
melhores conformações cresceram em meios com $25 \mu \mathrm{M} \cdot \mathrm{L}^{-1}$ de boro e concentraçõess distintas de cálcio.

$\mathrm{Na}$ Figura 10 A, observou-se que a região da coifa sofreu uma aparente diminuição, sendo o ápice radicular composto de células fortemente impregnadas por corante dificultando a visualização de seu formato e de seus núcleos. Percebeu-se em uma região superior a coifa, divisões celulares intensas, indicando processos meristemáticos.

Nas células localizadas acima do ápice da coifa, percebeu-se a diferenciação do córtex e o surgimento do cilindro vascular. Em cortes histológicos feitos em regiões medianas da raiz, verificou-se que as células que compunham o córtex apresentaram desestruturação e ruptura (Figura 10 B).

A epiderme foi composta por células de formatos alongados, localizadas na periferia da estrutura, seguidas por um córtex altamente desestruturado. Notou-se em uma região distinta o espessamento da epiderme, que apresentou células com conteúdo mais corado.

Os cortes transversais destas raízes mostraram uma epiderme organizada com células arredondadas, pequenas e com presença de pelos. Na região seguinte, verificou a presença da endoderme com células irregulares e pouco organizadas que em muitos pontos acabaram por não se diferenciar das células que compunham o córtex. $\mathrm{O}$ periciclo apresentou células arredondadas com uma coloração forte circundando a região do cilindro central, onde pode-se verificar o xilema e o floema (Figura $10 \mathrm{C}$ ).

Desta forma, podemos inferir que de acordo com as análises realizadas independente das concentraçõess de cálcio empregadas os tratamentos com concentrações de boro iguais a $25 \mu \mathrm{M} . \mathrm{L}^{-1}$ foram os que apresentaram estruturas radiculares com maiores diferenciações. 

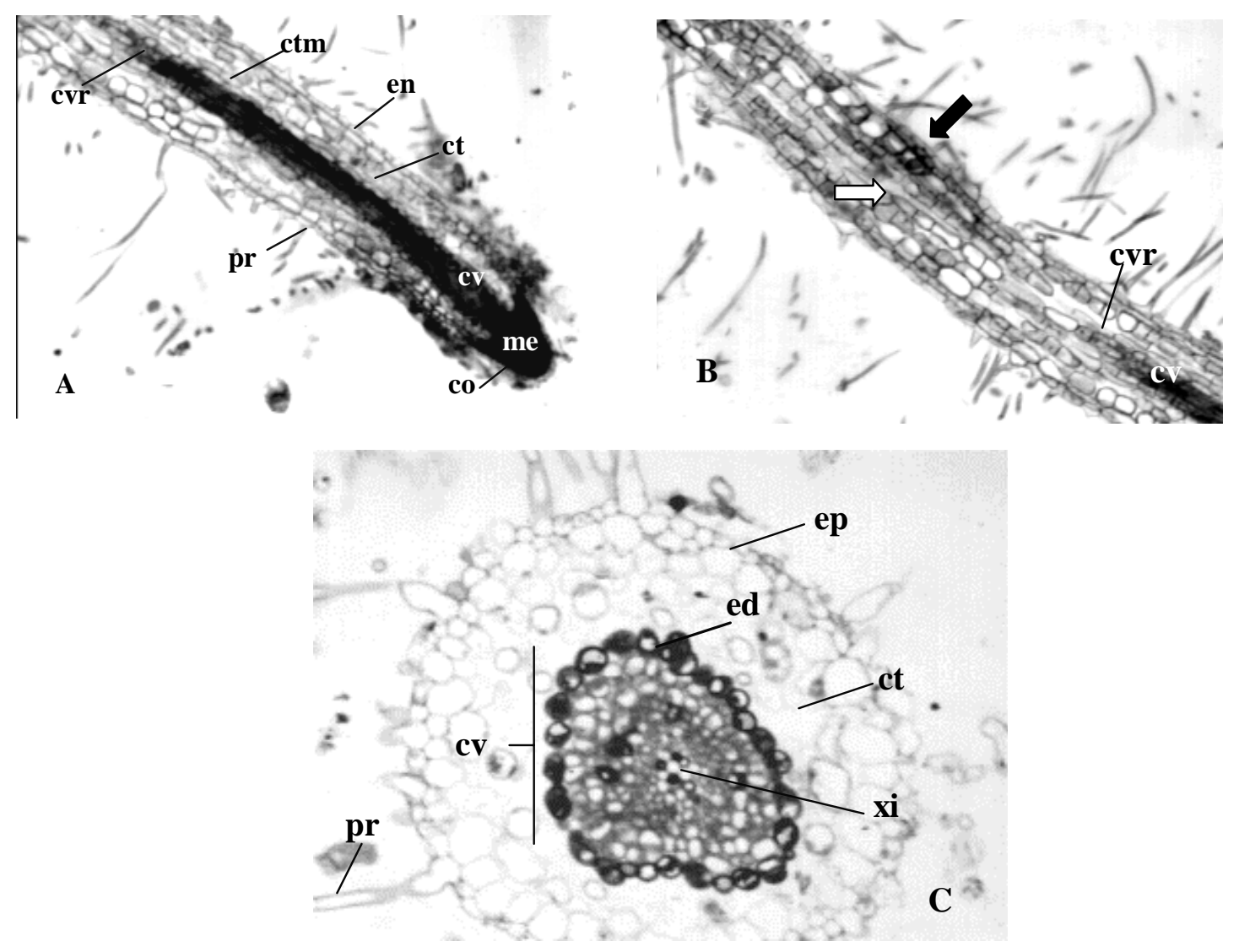

Figura 10 - Estruturas radiculares em corte longitudinal e transversal presente em combinações específicas de boro e cálcio (citadas anteriormente no texto). A) corte longitudinal de raiz apresentando diferenciações celulares; B) Detalhe da região do cilindro vascular apresentando desestruturação e rompimento (seta branca); área mais corada na região da epiderme e córtex (seta preta); C) Corte longitudinal com distinção das partes que compõem a raiz: co - coifa; me -região meristemática; cv - cilindro vascular; ct -córtex; ed - endoderme; ep- epiderme; ctm - córtex apresentando células modificadas e colapsadas; cvr - cilindro vascular com células rompidas; pr - pêlos radiculares 
Van De Venter \& Currier (1977) estudando plantas de feijão (Phaseolus vulgaris L. var Red Kidney) consideraram $0,25 \mathrm{mg} . \mathrm{L}^{-1}$ de boro, na solução nutritiva, como o nível ótimo para o desenvolvimento das mesmas. Já Moraes-Dallaqua et al. (2000) afirmam que o nível de $0,25 \mathrm{mg} . \mathrm{L}^{-1}$ de boro, na solução nutritiva, não foi suficiente para manter o desenvolvimento adequado das raízes, induzindo o aparecimento de sintomas de deficiência desse micronutriente.

Arruda (2004), ao mapear a presença de determinados metais em discos foliares de Passiflora edulis em processos de organogênese adventícia com imunofluorescência de raios-X, mostrou que em regiões organogênicas, o cálcio é participante ativo, juntamente com o potássio.

Diversos autores também sugerem que a omissão de boro em meio de cultura ocasiona freqüentemente o atraso do desenvolvimento de raízes (Chapman \& Jackson, 1974; Krueger et al., 1987) devido a sua atuação nos níveis de auxina endógena (Coke \& Whittington, 1968; Bisko et al., 1997). No entanto, de acordo com os dados foi possível evidenciar que na maioria das concentrações de boro utilizadas, o padrão de desenvolvimento das raízes foi similar, denotando desenvolvimento inconspícuo tanto em tamanho como em diâmetro.

Considerando-se a ausência de processos rizogênicos na omissão do boro e do cálcio no meio de cultura foi possível confirmar a atuação conjunta do boro e do cálcio aos 21 e 31 dias de cultivo in vitro, uma vez que na ausência dos nutrientes estudados inexistiu formação destas estruturas.

\subsubsection{Aspecto gelatinoso}

Os calos de E. urophylla cultivados no período de 21 dias, apresentaram aspectos gelatinosos nas combinações $0 \mu \mathrm{M} . \mathrm{L}^{-1}$ de boro com $0,3,75,7,5$ e 11,25 mM.L ${ }^{-1}$ de cálcio e $200 \mu \mathrm{M} . \mathrm{L}^{-1}$ de boro e $0 \mathrm{mM} . \mathrm{L}^{-1}$ de cálcio (Figura 1 e Figura $2 \mathrm{C}$ ).

Aparentemente o processo de diferenciação celular não foi atingido e a estruturação da parede celular ficou comprometida devido ao desbalanço nutricional do meio de cultura. Assim podemos inferir que as conformações gelatinosas dos calos 
devem-se a anormalidades na estruturação da parede celular decorrentes de concentraçõess deficientes de boro e cálcio.

Estas afirmativas podem ser visualizadas nos cortes histológicos dos calos desenvolvidos nas referidas combinações (Figura 11). Observou-se nos referidos cortes uma pronunciada desagregação celular com presença de células não coesas e com ausência de processos de diferenciação. Registrou-se também nestas combinações uma maior incidência de células arredondadas com tamanhos maiores, relação núcleo/citoplasmática baixa e núcleos pouco evidentes.

Verificou-se também através de contrastes da coloração que as paredes celulares dos calos com omissão de boro ou cálcio eram mais finas e delgadas do que as presentes em outros tratamentos.

Diversos autores confirmam a atuação deste macro e micronutriente na formação e gênese da parede e da membrana celular (Loomis \& Durst, 1992; Marschner, 1995; Hu \& Brown, 1994).

Trevizam (2001) ao estudar a interferência do boro em calos de Eucalyptus urophylla verificou este mesmo tipo de interferência quando se omitiu o micronutriente do meio de cultura.

Parr \& Loughman (1983) propuseram a existência de um sítio de ligação do boro na parede celular capaz de influenciar o metabolismo do cálcio. Em folhas de tomateiro, Yamauchi et al. (1986) mostraram que a deficiência de boro induziu a diminuição na quantidade de cálcio associado com pectinas da parede celular denotando uma anormalidade no desenvolvimento destes órgãos.

Teasdale \& Richards (1990), estudaram a relação boro e cálcio na estrutura e função da parede celular de Pinus radiata e sugeriram um modelo no qual o aceptor crítico de moléculas foi ativado em sítios diferentes somente por ligações de cálcio e boro. Os autores ainda encontraram que o macro e o micronutriente poderiam atuar como aceptores concorrentes na membrana, sendo que o boro se ligaria de forma mais forte que o cálcio evidenciando o papel do microelemento na biossíntese da parede 
celular, confirmando a provável interação destes nutrientes em processos de biogênese e estruturais da parede celular.

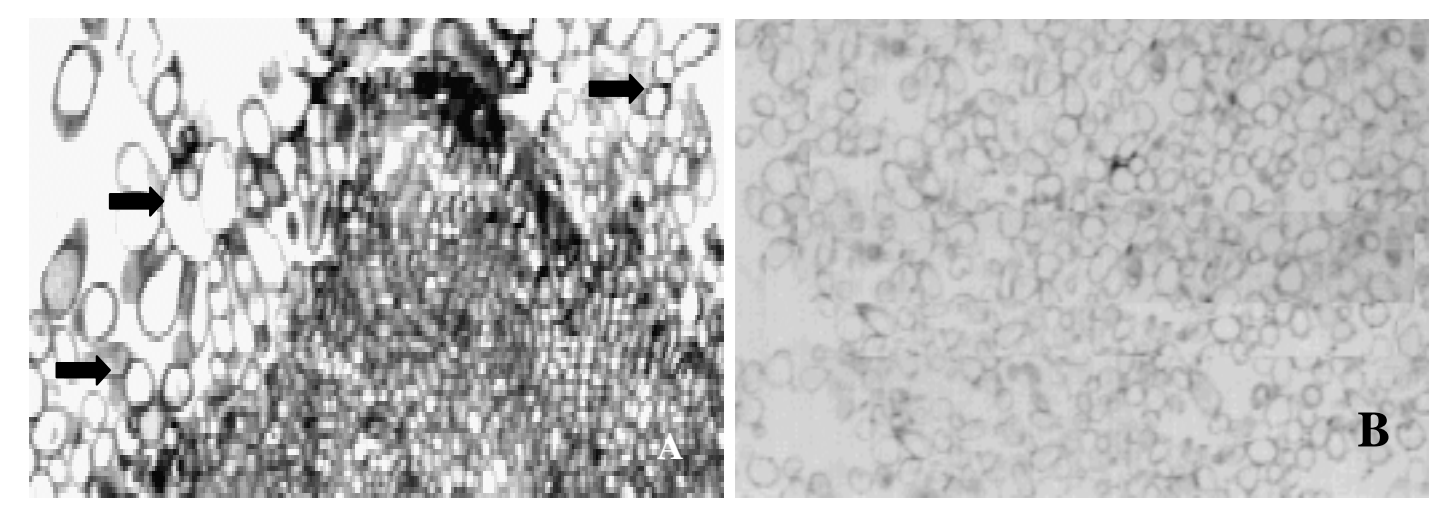

Figura 11 - Aspecto geral de calos onde foram verificadas características gelatinosas. A) Processo de desestruturação celular presente em calos cultivados por 21 dias (setas); B) Detalhe das regiões com desestruturação celular

\subsubsection{Estruturas globulares na superfície dos calos e friabilidade}

Os calos de E urophylla cultivados, aos 21 dias, nas combinações $25 \mu \mathrm{M} . \mathrm{L}^{-1}$ de boro com 7,5, 11,25 e $15 \mathrm{mM} . \mathrm{L}^{-1}$ de cálcio, $50 \mu \mathrm{M} . \mathrm{L}^{-1}$ de boro com 7,5, 11,25 mM.L $\mathrm{L}^{-1}$ de cálcio mostraram na superfície de alguns calos estruturas globulares. No período de 31 dias de cultivo, esse aspecto foi característico nos calos cultivados com a maioria das combinações com exceção de $25 \mu \mathrm{M} . \mathrm{L}^{-1}$ de boro com 0 e $3,75 \mathrm{mM} . \mathrm{L}^{-1}$ de cálcio, 50 $\mu \mathrm{M} . \mathrm{L}^{-1}$ de boro com 0 e $15 \mathrm{mM} . \mathrm{L}^{-1}$ de cálcio, $100 \mu \mathrm{M} . \mathrm{L}^{-1}$ de boro com 11,25 e 15 mM.L $\mathrm{L}^{-1}$ de cálcio, $200 \mu \mathrm{M} . \mathrm{L}^{-1}$ de boro com 0 e 3,75 mM.L ${ }^{-1}$ de cálcio e no meio padrão N7 (Simola, 1985).

Estas estruturas apresentaram aos 21 dias de cultivo in vitro aspectos mais brilhantes do que as do período posterior de análise (31 dias), fato que pôde ser visualizado através das Figuras 1, 2 D e 3. 
Segundo Rey et al. (1980) a conformação globular, friável e o crescimento dos calos são determinados pelas auxinas e citocininas, sendo que as primeiras determinam um calo mais friável enquanto as citocininas produzem calos mais firmes.

Para alguns autores, as formas globulares associadas à superfície dos calos, podem denotar a presença de organogênese e/ou embriogênese somática (Komatsu, 1995). Porém, contrariando estas afirmações as análises da morfologia interna mostraram a existência de regiões meristemáticas com intensa divisão não sendo registrados processos de embriogênese somática ou organogênese nestes tratamentos (Figura 12).

De acordo com os dados da morfologia interna, notou-se a existência de cinco regiões distintas nestes calos, denotando processos de diferenciação, sendo que estes tipos de conformações foram mais freqüentes em calos cultivados por 31 dias.

O primeiro tipo de agrupamento celular localizou-se nas regiões mais periféricas dos calos e apresentaram células com aspecto meristemático, altas relações núcleocitoplasmática, e alto índice mitótico (Figura 12 A). Ladeando estas células com características meristemáticas, verificou-se a presença de um segundo tipo celular de aspecto parenquimático, com relação núcleo citoplasmática menor e com células aparentemente de tamanhos superiores as apresentadas na Figura 12 A (Figura 12 B). O terceiro tipo mostrou um arranjo em estratos, com células de tamanho intermediário e núcleos pequenos (Figura $12 \mathrm{C}$ ), o quarto tipo mostrou células arredondadas, arranjadas frouxamente e com baixa relação núcleo-citoplasma (Figura 12 D) e o quinto tipo celular foi registrado na Figura 12 E, sendo composto de células de tamanhos superiores a todas as demais entremeadas com regiões de intensa divisão celular com tamanhos e conformação semelhante as que compunham o primeiro tipo (Figura $12 \mathrm{~A}$ ).

Embora as concentrações minerais presentes no meio de cultura não tenham proporcionado um desenvolvimento considerável em tratamentos mantidos in vitro por 31 dias, evidenciou-se intensos processos de diferenciação confirmando a ação interativa do boro e do cálcio como agentes atuantes na morfogênese. 
Estes resultados corroboram com as observações Trevizam (2001) que ao registrar a presença de estruturas globulares na superfície de calos de Eucalyptus urophylla cultivados in vitro com concentrações distintas de boro, comprovou através de análises histológicas a existência de centros meristemáticos com intensa divisão celular e com alguma capacidade embriogênica.

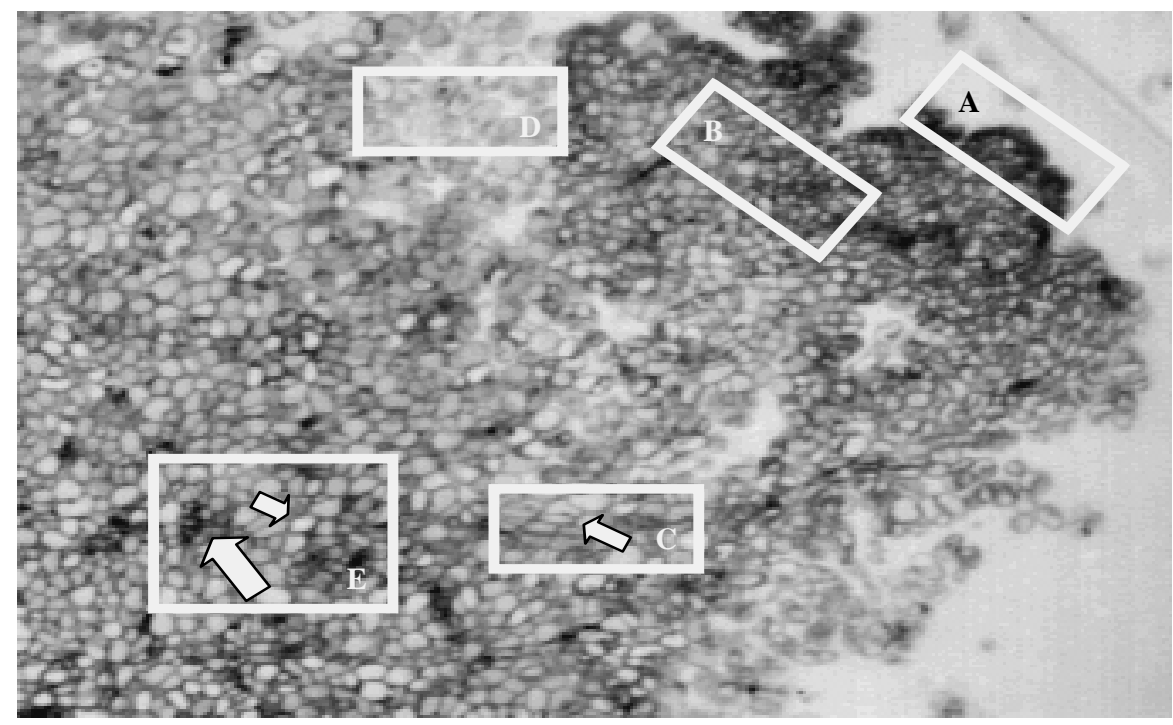

Figura 12 - Tipos celulares presentes em calos com aspecto globular. Detalhes: A) células menores e de aspecto meristemático, com relação núcleo/plasmática alta; B) células de tamanhos maiores, com baixa RPN denotando a esta região do calo aspecto um parenquimático; C) conjunto de células em estratos, indicando atividade cambial; D) baixa coesão celular, com grandes espaços intercelulares, caracterizando um aspecto frouxo em algumas nas regiões periféricas do calo; E) células de tamanho superior aos demais (seta maior) mescladas com células pequenas semelhantes ao tipo representado em A (seta menor)

Arruda et al. (2001) e Arruda et al. (2004) também registraram a ação do cálcio no desenvolvimento de embriões somáticos em calos E. urophylla e Citrus, afirmando 
que o macronutriente é acumulado em grande quantidade em materiais com potencial embriogênico.

Da mesma forma, que a presença de estruturas globulares, a friabilidade dos calos foi um aspecto comum nas culturas de calos (Figura 1, 2 E e 3). Aos 21 dias de cultivo e nas seguintes combinações $25 \mu \mathrm{M} . \mathrm{L}^{-1}$ de boro com 0 e $3,75 \mathrm{mM} . \mathrm{L}^{-1}$ de cálcio, $50 \mu \mathrm{M} . \mathrm{L}^{-1}$ de boro com $0 \mathrm{mM} . \mathrm{L}^{-1}$ de cálcio, $100 \mu \mathrm{M} . \mathrm{L}^{-1}$ de boro com 0 e 7,5 mM.L $\mathrm{L}^{-1}$ de cálcio, $200 \mu \mathrm{M} . \mathrm{L}^{-1}$ de boro com 11,25 e $15 \mathrm{mM} . \mathrm{L}^{-1}$ de cálcio houve a formação de estruturas friáveis. Tal aspecto foi também visualizado no período de 31 dias nas seguintes combinações $0 \mu \mathrm{M} . \mathrm{L}^{-1}$ de boro com 3,75, 7,5, 11,25 e $15 \mathrm{mM} . \mathrm{L}^{-1}$ de cálcio, 50 $\mu \mathrm{M} . \mathrm{L}^{-1}$ de boro com $3,75,7,5$ e $15 \mathrm{mM} . \mathrm{L}^{-1}$ de cálcio e $100 \mu \mathrm{M} . \mathrm{L}^{-1}$ de boro com 15 mM.L $\mathrm{L}^{-1}$ de cálcio. Contudo, no período de maior tempo de cultivo a estrutura geral dos calos foi comprometida pela oxidação.

De acordo com os cortes anatômicos internos verificou-se que nestes tratamentos os processos de diferenciação celular não foram comuns, denotando a incapacidade de um desenvolvimento morfogenético posterior em calos cultivadas nestas concentrações especificas de boro e cálcio. De modo geral, as células destes tratamentos apresentaram baixa relação núcleo-plasmática (RNP), ou seja, tamanhos grandes, núcleos pequenos muitas vezes não visualizados, associada a reduzida presença de grãos de amido e parede celular mais delgada (Figura 13).

Embora a conformação das células obedecesse ao padrão geral descrito, verificou-se nos calos cultivados nas combinações $0 \mu \mathrm{M} . \mathrm{L}^{-1}$ de boro com 3,75, 7,5, 11,25 e 15 mM.L ${ }^{-1}$ de cálcio, $50 \mu \mathrm{M} . \mathrm{L}^{-1}$ de boro com 3,75, 7,5 e $15 \mathrm{mM} . \mathrm{L}^{-1}$ de cálcio e $100 \mu \mathrm{M} . \mathrm{L}^{-1}$ de boro com $15 \mathrm{mM} . \mathrm{L}^{-1}$ de cálcio, aos 31 dias de cultivo, regiões internas com processos de diferenciação, que poderiam indicar processos rizogênicos. 

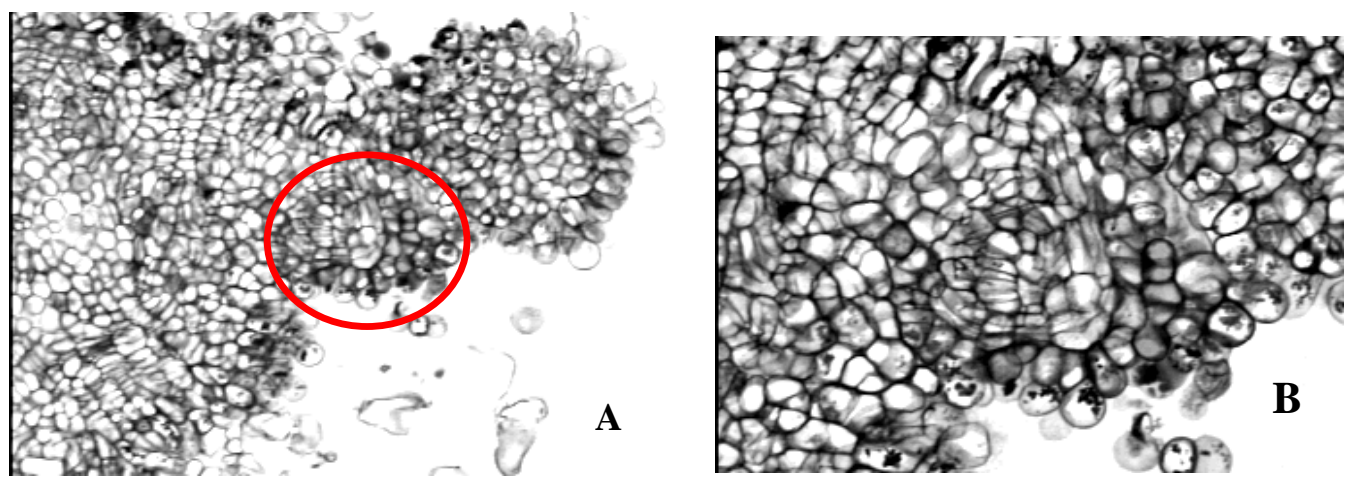

Figura 13 - Aspecto geral da morfologia interna de calos com característica friável. A) Conformação geral das células com aspecto pouco diferenciado. A circunferência delimita um detalhe do calo; B) Detalhe de A, com região apresentando provável processo de diferenciação meristemática e rizogênica em calos cultivados in vitro por 31 dias

\subsubsection{Presença de pigmentos e metabólitos secundários}

De acordo com os dados da morfologia externa apresentados na Figura 1 e na Figura 3 verificou-se a presença de dois pigmentos distintos nos calos de E. urophylla, sendo um caracterizado pela cor marrom (fenol) e outro com coloração vermelha característica (antocianina).

A oxidação mostrou relação com os baixos índices de desenvolvimento das estruturas cultivadas por 21 dias em concentraçõess inadequadas de nutrientes minerais no meio de cultura. De acordo com a Figura 1 e em detalhe na Figura 2 E, observou-se na maioria das interações de boro com cálcio, uma maior incidência do pigmento marrom (fenol). Nas combinações $25 \mu \mathrm{M} . \mathrm{L}^{-1}$ de boro com $15 \mathrm{mM} . \mathrm{L}^{-1}$ de cálcio, 50 $\mu \mathrm{M} . \mathrm{L}^{-1}$ de boro com $0,3,75,7,5,11,25$ e $15 \mathrm{mM} . \mathrm{L}^{-1}$ de cálcio, $100 \mu \mathrm{M} . \mathrm{L}^{-1}$ de boro com 0 mM.L ${ }^{-1}$ de cálcio e no meio N7 padrão (Simola, 1985) não foram verificados calos oxidados. 
Entretanto, para o período de 31 dias, a oxidação dos calos foi evidenciada em todos os tratamentos. Na combinação $200 \mu \mathrm{M} . \mathrm{L}^{-1}$ de boro com $15 \mathrm{mM} . \mathrm{L}^{-1}$ de cálcio a oxidação causou maiores danos aos calos, tornando-os mais escuros do que nos demais tratamentos (Figura 3).

As análises anatômicas evidenciaram nos cortes a presença de regiões mais escuras que comprovaram a presença de tecidos mortos em áreas com presença de oxidação (Figura 14). Nestas regiões os contornos celulares foram pouco evidentes bem como os processos de divisões celulares. Verificou-se na literatura que o escurecimento de explantes determinam dificuldades no estabelecimento de culturas in vitro em algumas espécies lenhosas, provavelmente em decorrência da liberação de compostos fenólicos pelos tecidos em resposta a ferimentos, altas concentrações de reguladores vegetais e pela oxidação de polifenóis e quinonas (Pious \& Ravindra, 1997).

Notou-se que para os calos cultivado no período de 21 dias as áreas oxidadas apresentaram uma área maior e uma distribuição localizada principalmente nas regiões periféricas da massa de calos, enquanto o agrupamento de células com oxidação presente em calos cultivados in vitro por 31 dias distribuíram-se pelas regiões periféricas e também ao longo de todo o calo concentrando-se em porções menores (Figura 14).

Independentemente das concentrações de cálcio, verificou-se que aos 21 dias de cultivo, o meio de cultura com 0 e $25 \mu \mathrm{M} . \mathrm{L}^{-1}$ de boro apresentaram índices de oxidação inversamente proporcionais ao tamanho (Figura 4 e Figura 1). De acordo com Cakmak et al. (1995), em muitos casos a deficiência de boro associa-se ao escurecimento de tecidos foliares, sendo este escurecimento uma conseqüência provável do aumento do acúmulo de fenóis e da atividade da polifenol-oxidase (PPO). As quinonas produzidas pela PPO são polimerizadas e geram pigmentos marrons. $\mathrm{O}$ acúmulo de quantidades substanciais de quinonas em espécies de plantas sensíveis a deficiência de boro tem sido considerada como a maior causa de danos e suspensão do crescimento celular em diversas espécies vegetais (Lee \& Aronoff, 1967). 

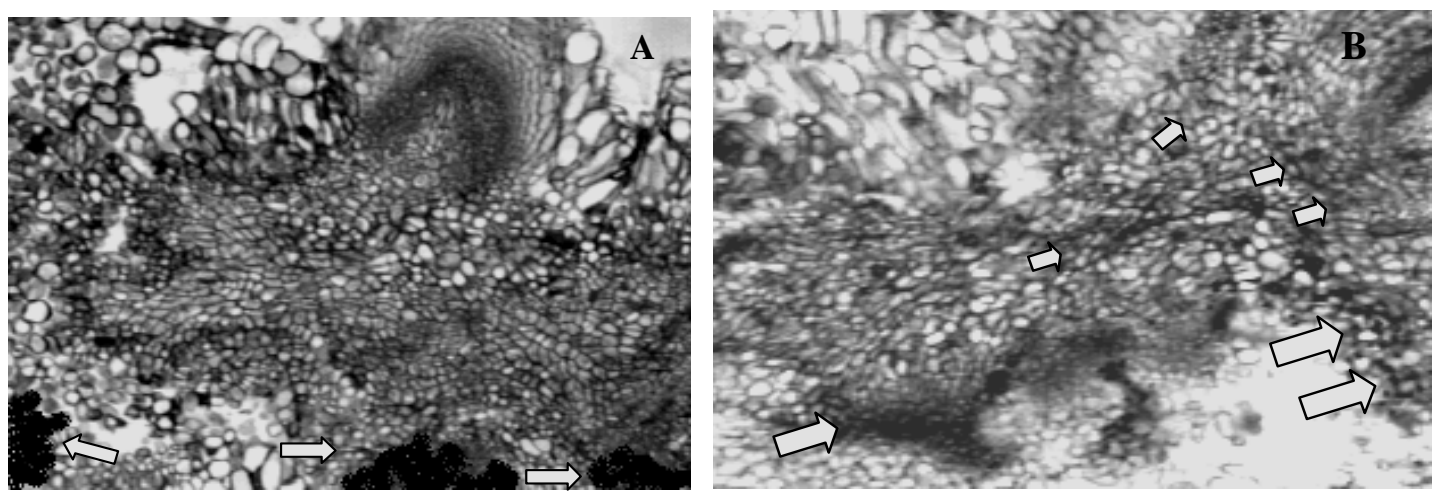

Figura 14 - Aspecto das áreas oxidadas em calos de E. urophylla cultivados in vitro em períodos distintos com concentrações de boro e cálcio. A) Área de oxidação localizada na periferia dos calos presente em tratamentos cultivados in vitro por 21 dias (seta); B) Presença de áreas oxidadas em calos cultivados por 31 dias, ressaltando áreas periféricas com oxidação (setas maiores) e áreas internas com a mesma característica (setas menores)

Da mesma forma que nas concentrações deficientes, as concentrações com 100 e $200 \mu \mathrm{M} . \mathrm{L}^{-1}$ de boro também apresentaram pigmentos característicos de oxidação. Evidenciando que a produção de fenóis pode ser uma resposta ao desbalanço do meio de cultura e que o cálcio não foi capaz de mediar esta acumulação nas células. Estas evidências foram observadas também nos estudos desenvolvidos por Trevizam (2001), que também registrou a oxidação de calos em concentrações de boro superiores a $50 \mu \mathrm{M} . \mathrm{L}^{-1}$.

Diferentemente da coloração marrom, os tons de vermelho pareceram estar relacionados com o tamanho dos calos. Desta forma, aos 21 dias de cultivo, a combinação $50 \mu \mathrm{M} . \mathrm{L}^{-1}$ de boro com $7,5 \mathrm{mM} \cdot \mathrm{L}^{-1}$ de cálcio apresentou calos com coloração vermelha marcante (Figura 1 e Figura $2 \mathrm{~F}$ ) e ao mesmo tempo apresentou os maiores tamanhos médios (Figura 4). Em calos cultivados por 31 dias, a expressão da 
antocianina foi fraca sendo visualiza apenas na combinação $50 \mu \mathrm{M} . \mathrm{L}^{-1}$ de boro com 11,25 mM.L ${ }^{-1}$ de cálcio.

De acordo com Reinert \& Yeoman (1982) a cultura in vitro de células de plantas superiores pode acumular uma grande variedade de metabólicos secundários como polifenóis, alcalóides, esteróides e antocianinas que tendem a se perder em períodos prolongados de cultivo.

De acordo com as análises da morfologia interna verificou-se que os calos cultivados in vitro, principalmente por 21 dias, apresentaram em seu interior estruturas arredondadas com pigmentos (antocianinas) e também estruturas com formas circulares irregulares e/ou elípticas que se assemelhavam a grãos de amido (Figura 15).

$\mathrm{Na}$ literatura, tanto a presença de amido como de antocianinas são relacionadas com processos de morfogênese em calos. Assim de acordo com os resultados obtidos verificou-se que a presença de células contendo grãos de amido foi visualizada principalmente em regiões celulares próximas a centros de aspecto meristemático com capacidade morfogênica.

De forma especifica, grãos de amido têm sido apontados como indicadores de processos embriogênicos. Desta forma, Ribas (1999) e Steiner et al. (2003) comprovaram em estudos com espécies distintas (Aspidosperma polyneuron e Araucária angustifólia, respectivamente) a relação da presença de grãos de amido com processos de embriogênese somática in vitro. Estes dados puderam ser confirmados através da Figura 16 onde se observam os cortes histológicos referentes aos calos desenvolvidos nas seguintes interações $50 \mu \mathrm{M} . \mathrm{L}^{-1}$ de boro com 7,5, 11,25 e $15 \mathrm{mM} . \mathrm{L}^{-1}$ de cálcio, que aos 21 dias de cultivo in vitro evidenciaram a presença de pré-embriões somáticos originados de forma independente a partir de divisões celulares nas camadas mais externas do calo. 


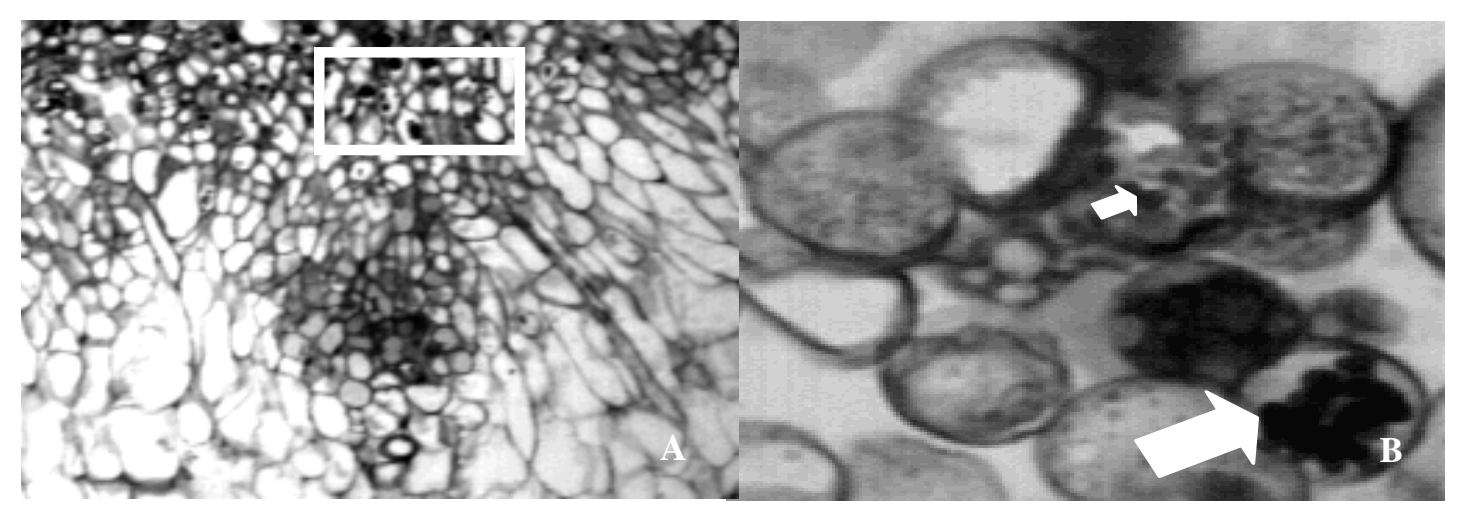

Figura 15 - Cortes histológicos de calos de E. urophylla aos 21 dias de cultivo in vitro apresentando granulações intracelulares. A) Visão geral da área do calo; B) Detalhe das estruturas, onde a seta maior aponta a presença de plastos compostos por pigmentos avermelhados e a seta menor mostra a presença de prováveis grãos de amido

Notou-se aos 21 dias de cultivo, que a presença de grãos de amido nas combinações $0 \mu \mathrm{M} . \mathrm{L}^{-1}$ de boro com 0 e $15 \mathrm{mM} . \mathrm{L}^{-1}$ de cálcio, $25 \mu \mathrm{M} . \mathrm{L}^{-1}$ de boro com 3,75 e $15 \mathrm{mM} . \mathrm{L}^{-1}$ de cálcio, $50 \mu \mathrm{M} . \mathrm{L}^{-1}$ de boro com $0, \mathrm{mM} . \mathrm{L}^{-1}$ de cálcio, $100 \mu \mathrm{M} . \mathrm{L}^{-1}$ de boro com 3,75 e 11,25 mM.L ${ }^{-1}$ de cálcio e $200 \mu \mathrm{M} . \mathrm{L}^{-1}$ de boro com 7,5 mM.L ${ }^{-1}$ de cálcio foi comum, no entanto nestas interações não verificou o desenvolvimento de préembriões somáticos e sim a gênese de meristemóides em regiões não específicas do calo.

Embora as características das células meristemáticas para todos os tratamentos sejam semelhantes, o grau de diferenciação apresentado na interação $50 \mu \mathrm{M} \cdot \mathrm{L}^{-1}$ de boro com 7,5 mM.L $\mathrm{L}^{-1}$ de cálcio parece ser mais determinado em relação aos demais, denotando um grau mais adiantado de diferenciação.

A presença de pigmentos vermelhos (antocianinas) nos calos cultivados in vitro por 21 dias foi observada nas mesmas combinações de boro e cálcio em que foram 
verificados os grãos de amido. Sendo que na combinação $50 \mu \mathrm{M} \cdot \mathrm{L}^{-1}$ de boro com 7,5 mM.L $\mathrm{L}^{-1}$ de cálcio foi identificado a maior presença do pigmento vermelho. Nestes tratamentos os calos se constituíram de aspecto nodular associadas à presença de antocianinas. A relação existente entre a presença de antocianina e a organogênese foi relatada por Muralidharan \& Mascarenhas (1987) que, em explantes foliares de Eucalyptus. camaldulensis, verificaram que os calos formados desenvolveram antocianina e, após quatro semanas de cultivo, gemas iniciais se desenvolviam nessas áreas de pigmentação. Subbaiah \& Minocha (1990), em trabalho com folhas e caule de Eucalyptus tereticornis, constataram que os calos sempre se tornavam avermelhados antes do aparecimento dos primórdios de gemas. Também, Arruda et al. (2001) ao analisar calos de E. urophylla cultivados com concentrações diferentes de cálcio, verificaram que a presença deste pigmento em calos de E. urophylla revelava a formação de gemas, ao passo que Trevizam (2001) estudando a mesma espécie com concentrações de boro observou a presença de antocianinas associadas a formação de

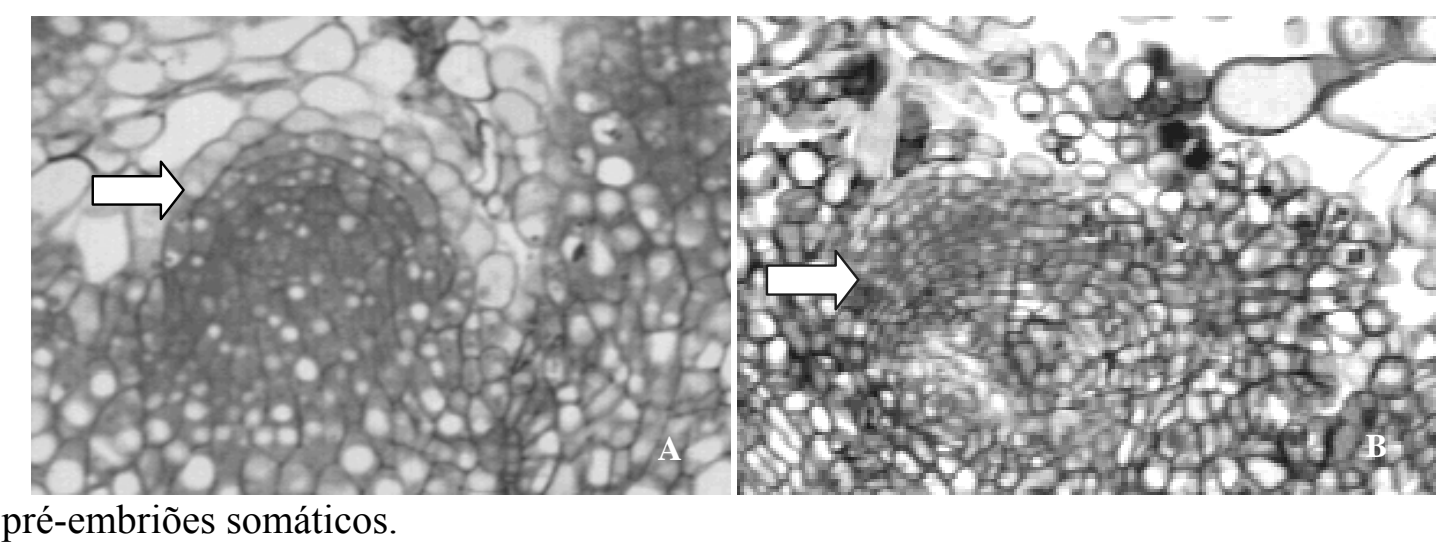

Figura 16 - Morfologia interna de calos de E. urophylla cultivados in vitro por 21 dias evidenciando estruturas morfogênicas. A) Estrutura meristemática rizogênica originada a partir da periferia do calo (seta); B) Presença de meristemóides (seta) evidenciando a capacidade de diferenciação celular em tratamentos específicos (descritos anteriormente) 


\subsection{Análises quantitativas}

\subsubsection{Considerações gerais}

Os quadrados médios das análises de variância e os coeficientes de variação para as variáveis em estudo, massa fresca $(\mathrm{g})$, massa seca $(\mathrm{mg})$, prolina ( $\mu \mathrm{g} / \mathrm{g}$ Massa Fresca), carboidratos não estruturais solúveis totais ( $\mathrm{mg} / \mathrm{g}$ Massa Fresca) e proteína solúvel total (mg / g Massa Fresca), avaliadas aos 21 e 31 dias de cultivo in vitro para calos de E. urophylla, estão apresentados nas Tabelas 3, 4, 5 e 6.

Tabela 3. Resumo da análise de variância para as características massa fresca (g) e massa seca (mg) avaliadas aos 21 dias de cultivo in vitro para calos de $E$. urophylla

\begin{tabular}{|c|c|c|c|}
\hline \multirow{2}{*}{ Fonte de Variação } & \multirow{2}{*}{ G.L. } & \multicolumn{2}{|c|}{ Quadrado Médio } \\
\hline & & Massa fresca $(\mathrm{g})$ & Massa seca (mg) \\
\hline Tratamentos & $(25)$ & $2,34 * *$ & $8128,62 * *$ \\
\hline Fatorial & (24) & $2,17 * *$ & $6926,62 * *$ \\
\hline Boro & 4 & $7,64 * *$ & $34146,18^{* *}$ \\
\hline Cálcio & 4 & $2,24 * *$ & $5111,75^{* *}$ \\
\hline Boro x Cálcio & 16 & $0,77 * *$ & $575,44 * *$ \\
\hline Fatorial vs Test & 1 & $6,45^{* *}$ & $36976,78^{* *}$ \\
\hline Resíduo & 52 & 0,03 & 106,47 \\
\hline C.V. $(\%)$ & & 0,61 & 5,77 \\
\hline
\end{tabular}


Tabela 4. Resumo da análise de variância para as características prolina ( $\mu \mathrm{g} / \mathrm{g}$ Massa Fresca), carboidratos não estruturais solúveis totais (mg / g Massa Fresca), proteína solúvel total (mg / g Massa Fresca) avaliadas aos 21 dias de cultivo in vitro para calos de E. urophylla

\begin{tabular}{lcccc}
\hline Fonte de Variação & G.L. & $\begin{array}{c}\text { Prolina } \\
(\mu \mathrm{g} / \mathrm{g} \mathrm{MF})\end{array}$ & $\begin{array}{c}\text { Quadrado Médio } \\
\text { Carboidratos não } \\
\text { totais }(\mathrm{mg} / \mathrm{g} \mathrm{MF})\end{array}$ & $\begin{array}{c}\text { Proteínas solúveis } \\
\text { totais } \\
(\mathrm{mg} / \mathrm{g} \mathrm{MF})\end{array}$ \\
\hline Tratamentos & $(25)$ & $1675,95^{* *}$ & $13,77^{* *}$ & $7,26^{* *}$ \\
Fatorial & $(24)$ & $1614,93^{* *}$ & $14,12^{* *}$ & $5,03^{* *}$ \\
Boro & 4 & $1852,04^{* *}$ & $15,94^{* *}$ & $15,15^{* *}$ \\
Cálcio & 4 & $755,28^{*}$ & $31,99^{* *}$ & $4,39^{* *}$ \\
Boro x Cálcio & 16 & $1770,56^{* *}$ & $9,20^{* *}$ & $2,66^{* *}$ \\
Fatorial vs Test & 1 & $3140,37^{* *}$ & $5,26^{*}$ & $60,82^{* *}$ \\
Resíduo & 52 & 207,02 & 0,84 & 0,24 \\
C.V. (\%) & & 14,70 & 9,88 & 3,91 \\
\hline
\end{tabular}

*Significativo a 5\%; **Significativo a 1\%; GL - Graus de Liberdade; CV - Coeficiente de Variação

Tabela 5. Resumo da análise de variância para as características massa fresca (g) e massa seca (mg) avaliadas aos 31 dias de cultivo in vitro para calos de $E$. urophylla

\begin{tabular}{lccc}
\hline \multirow{2}{*}{ Fonte de Variação } & G.L. & \multicolumn{2}{c}{ Quadrado Médio } \\
& & Massa fresca $(\mathrm{g})$ & Massa seca $(\mathrm{mg})$ \\
\hline Tratamentos & $(25)$ & $1,81^{* *}$ & $8526,99^{* *}$ \\
Fatorial & $(24)$ & $1,27^{* *}$ & $7296,18^{* *}$ \\
Boro & 4 & $4,08^{* *}$ & $37999,50^{* *}$ \\
Cálcio & 4 & $2,56^{* *}$ & $3528,20^{* *}$ \\
Boro x Cálcio & 16 & $0,25^{* *}$ & $562,34 * *$ \\
Fatorial vs Test & 1 & $14,64^{* *}$ & $38066,72^{* *}$
\end{tabular}


$\begin{array}{lccc}\text { Resíduo } & 52 & 0,001 & 0,105 \\ \text { C.V. }(\%) & 1,06 & 0,20\end{array}$

*Significativo a 5\%, **Significativo a 1\%;GL - Graus de Liberdade; CV - Coeficiente de Variação

Tabela 6. Resumo da análise de variância para as características prolina ( $\mu \mathrm{g} / \mathrm{g}$ Massa Fresca), carboidratos não estruturais solúveis totais (mg / g Massa Fresca), proteína solúvel total (mg / g Massa Fresca) avaliadas aos 31 dias de cultivo in vitro para calos de E. urophylla

\begin{tabular}{lcccc}
\hline Fonte de Variação & G.L. & $\begin{array}{c}\text { Prolina } \\
(\mu \mathrm{g} / \mathrm{g} \mathrm{MF})\end{array}$ & $\begin{array}{c}\text { Quadrado Médio } \\
\text { Carboidratos não } \\
\text { estruturais solúveis } \\
\text { totais }(\mathrm{mg} / \mathrm{g} \mathrm{MF})\end{array}$ & $\begin{array}{c}\text { Proteínas } \\
\text { solúveis totais } \\
(\mathrm{mg} / \mathrm{g} \mathrm{MF})\end{array}$ \\
\hline Tratamentos & $(25)$ & $4316,80^{* *}$ & $21,27^{* *}$ & $0,94^{\mathrm{ns}}$ \\
Fatorial & $(24)$ & $4270,84^{* *}$ & $21,90^{* *}$ & $0,98^{\mathrm{ns}}$ \\
Boro & 4 & $1837,38^{* *}$ & $19,33^{* *}$ & $0,81^{\mathrm{ns}}$ \\
Cálcio & 4 & $9401,65^{* *}$ & $14,24^{* *}$ & $1,35^{\mathrm{ns}}$ \\
Boro x Cálcio & 16 & $3596,49^{* *}$ & $24,46^{* *}$ & $0,93^{\mathrm{ns}}$ \\
Fatorial vs Test & 1 & $5419,99^{* *}$ & $6,16^{* *}$ & $0,03^{\mathrm{ns}}$ \\
Resíduo & 52 & 365,17 & 0,21 & 0,57 \\
C.V. (\%) & & 14,71 & 6,97 & 9,31 \\
\hline
\end{tabular}

*Significativo a 5\%; **Significativo a 1\%; ns: não significativo; GL - Graus de Liberdade; CV Coeficiente de Variação

A análise de variância para as características avaliadas aos 21 dias de cultivo, mostrou, para todas as variáveis, um efeito altamente significativo para a fonte de variação tratamentos (Tabelas 3 e 4).

Observando-se o desdobramento dos graus de liberdade de tratamentos, notou-se um efeito significativo para boro, cálcio, para a interação boro e cálcio e também para o contraste entre testemunha e tratamentos, para todas as variáveis avaliadas. Desta forma verificou-se então, a existência de uma diferença entre as concentrações de boro e cálcio, em relação às variáveis analisadas, ou seja, determinadas concentrações de boro e 
também de cálcio adicionas ao meio de cultura foram capazes de provocar alterações significativas nas concentrações das variáveis analisadas.

Constatou-se também, que a interação boro e cálcio foi significativa, indicando que determinadas concentrações se combinaram melhor entre si e outras combinações foram desfavoráveis. A significância do contraste das testemunhas e os tratamentos indicou que a testemunha foi diferente em relação aos tratamentos para todas as características avaliadas. Assim procedeu-se apenas o estudo dos desdobramentos das interações, pois um fator está influenciando o outro em relação às variáveis analisadas e portanto, não podem ser analisados isoladamente.

Os coeficientes de variação foram de $0,61 \%, 5,77 \%, 14,70 \%, 9,88 \%$ e 3,91\% respectivamente, para as variáveis massa fresca, massa seca, prolina, carboidratos não estruturais solúveis totais e proteína solúveis totais, indicando uma boa precisão experimental (Tabelas 3 e 4 ).

De acordo com a análise de variância para as características avaliadas aos 31 dias de cultivo, verificou-se um efeito altamente significativo para a fonte de variação tratamentos para todas as variáveis avaliadas, com exceção da variável proteína solúvel total (Tabelas 5 e 6$)$.

Observando-se o desdobramento dos graus de liberdade de tratamentos, verificou-se efeito altamente significativo para boro, cálcio, para a interação boro e cálcio e também para o contraste entre testemunha e tratamentos. Somente a variável proteína solúvel total não apresentou diferença significativa para as concentraçõess de boro e cálcio, para a interação e para o contraste da testemunha com os tratamentos, indicando que aos 31 dias de cultivo, as concentrações de boro e cálcio não influenciaram na quantidade de proteína produzida.

Desta forma verificou-se então, com exceção da proteína, a existência de uma diferença entre as concentrações de boro e cálcio em relação às variáveis analisadas, ou seja, determinadas concentrações de boro e também de cálcio adicionas ao meio de cultura provocaram alterações significativas nas quantidades das variáveis analisadas aos 31 dias de cultivo. 
Ainda analisando as Tabelas 5 e 6, verificou-se que a interação boro e cálcio foi significativa, indicando que determinadas concentrações desses dois nutrientes combinaram melhor ou de forma não satisfatória, entre si, na composição do meio de cultura.

A significância do contraste das testemunhas e os tratamentos, indicaram que a testemunha foi diferente em relação aos tratamentos. Desta forma, com exceção da proteína, procedeu-se apenas o estudo dos desdobramentos das interações, pois um fator está influenciando o outro em relação às variáveis analisadas e portanto, não podem ser analisadas isoladamente.

Os coeficientes de variação foram de 1,06\%, 0,20\%, 14,71\%, 6,97\% e 9,31\%, respectivamente, para as variáveis massa fresca, massa seca, prolina, carboidratos não estruturais solúveis totais e proteínas solúveis totais, indicando uma boa precisão experimental (Tabelas 5 e 6 ).

\subsubsection{Avaliação de massa fresca e seca em calos de $E$. urophylla}

\subsubsection{Avaliação de massa fresca em função das concentrações de boro com diferentes concentrações de cálcio aos 21 e 31 dias de cultivo in vitro}

As Tabelas 7 e 8 apresentam os modelos de regressão ajustados para a variação da concentração de boro dentro de cálcio, respectivamente aos 21 e 31 dias para a variável massa fresca de calos.

As equações de regressão referentes à variável massa fresca avaliada aos 21 dias de cultivo em função das concentrações de boro com diferentes concentrações de cálcio estão expressas na Tabela 7. Observou-se que os modelos que melhor se ajustaram as diferentes concentrações de cálcio foram os de regressão cúbica, com exceção da concentração 7,50 mM.L ${ }^{-1}$ de cálcio, cujo modelo de melhor ajuste foi quadrático, sendo todos significativos a $1 \%$ pelo teste $\mathrm{F}$ da análise da variância da regressão. 
Tabela 7. Equações de regressão correspondentes às concentrações de boro (B), em $\mu \mathrm{M} . \mathrm{L}^{-1}$, dentro de cada concentração de cálcio $(\mathrm{Ca})$, em mM.L ${ }^{-1}$, no meio de cultura, para a característica massa fresca (g) de calos de E urophylla avaliada aos 21 dias de cultivo in vitro

\begin{tabular}{llcc}
\hline & \multicolumn{1}{c}{ Equação } & $\mathrm{R}^{2}$ & $\mathrm{P}<\mathrm{F}$ \\
\hline B dentro de Ca 0 & $\hat{\mathrm{Y}}=2,0357+0,0597 \mathrm{x}-0,0004 \mathrm{x}^{2}+0,1 \mathrm{E}-5 \mathrm{x}^{3}$ & 0,98 & 0,000 \\
B dentro de Ca 3,75 & $\hat{\mathrm{Y}}=3,4011+0,0319 \mathrm{x}-0,0003 \mathrm{x}^{2}+0,1 \mathrm{E}-5 \mathrm{x}^{3}$ & 0,75 & 0,000 \\
B dentro de Ca 7,50 & $\hat{\mathrm{Y}}=3,5812+0,0284 \mathrm{x}-0,0001 \mathrm{x}^{2}$ & 0,95 & 0,000 \\
B dentro de Ca 11,25 & $\hat{\mathrm{Y}}=3,3240+0,0542 \mathrm{x}-0,0008 \mathrm{x}^{2}+0,3 \mathrm{E}-5 \mathrm{x}^{3}$ & 0,68 & 0,000 \\
B dentro de Ca 15 & $\hat{\mathrm{Y}}=2,9343+0,0689 \mathrm{x}-0,0010 \mathrm{x}^{2}+0,4 \mathrm{E}-5 \mathrm{x}^{3}$ & 0,79 & 0,000 \\
\hline
\end{tabular}

As equações de regressão referentes à variável massa fresca avaliada aos 31 dias de cultivo em função das concentrações de boro com diferentes concentrações de cálcio estão expressas na Tabela 8. Observa-se que os modelos que melhor se ajustaram as diferentes concentraçõess de cálcio foram os modelos de regressão cúbica, sendo todos significativos a $1 \%$ pelo teste $\mathrm{F}$ da análise da variância da regressão. Para as concentrações 0 e 11,25 mM.L $\mathrm{L}^{-1}$ de cálcio, o modelo não se ajustou perfeitamente, pois apresentaram um $\mathrm{R}^{2}$ inferior a 0,50 (respectivamente, 0,54 e 0,50).

Tabela 8. Equações de regressão correspondentes às concentrações de boro (B), em $\mu \mathrm{M} . \mathrm{L}^{-1}$, dentro de cada concentração de cálcio $(\mathrm{Ca})$, em mM.L ${ }^{-1}$, no meio de cultura, para a característica massa fresca de calos de E. urophylla avaliada aos 31 dias de cultivo in vitro

\begin{tabular}{lccc}
\hline & \multicolumn{1}{c}{ Equação } & $\mathrm{R}^{2}$ & $\mathrm{P}<\mathrm{F}$ \\
\hline B dentro de Ca 0 & $\hat{\mathrm{Y}}=2,1570+0,0284 \mathrm{x}-0,0004 \mathrm{x}^{2}+0,1 \mathrm{E}-5 \mathrm{x}^{3}$ & 0,54 & 0,000 \\
B dentro de Ca 3,75 & $\hat{\mathrm{Y}}=2,7398+0,0465 \mathrm{x}-0,0005 \mathrm{x}^{2}+0,2 \mathrm{E}-5 \mathrm{x}^{3}$ & 0,79 & 0,000 \\
B dentro de Ca 7,50 & $\hat{\mathrm{Y}}=2,9081+0,0610 \mathrm{x}-0,0007 \mathrm{x}^{2}+0,2 \mathrm{E}-5 \mathrm{x}^{3}$ & 0,81 & 0,000
\end{tabular}


B dentro de Ca $11,25 \quad \hat{\mathrm{Y}}=2,8571+0,0366 \mathrm{x}-0,0005 \mathrm{x}^{2}+0,2 \mathrm{E}-5 \mathrm{x}^{3} \quad 0,50 \quad 0,000$

B dentro de Ca $15 \quad \hat{Y}=2,3922+0,0393 x-0,0004 x^{2}+0,1 E-5 x^{3} \quad 0,99 \quad 0,000$

$\mathrm{O}$ acréscimo do teor de massa fresca de calos de E. urophylla aos 21 dias de cultivo in vitro foi marcadamente influenciado pela disponibilidade do micronutriente para todas as concentraçõess de cálcio. Quanto aos efeitos das concentrações de boro sobre a massa fresca, pode-se verificar que houve um aumento do teor de massa fresca ao se elevar as concentrações desse micronutriente, independente das concentrações de cálcio (Figura 17).

De acordo com os dados, o menor teor de massa fresca foi encontrado na concentração $0 \mathrm{mM} \cdot \mathrm{L}^{-1}$ de cálcio e $0 \mu \mathrm{M} . \mathrm{L}^{-1}$ de boro, enquanto o maior teor de massa fresca foi verificado na interação de $15 \mathrm{mM} . \mathrm{L}^{-1}$ de cálcio e $200 \mu \mathrm{M} . \mathrm{L}^{-1}$ de boro. Na presença desses nutrientes, com as concentrações citadas anteriormente, o teor de massa fresca foi até 4 vezes superior, se comparado com a omissão dos dois nutrientes do meio de cultura. Observou-se também, que independente da concentração de cálcio a maior produção de massa fresca ocorreu sempre nas maiores concentraçõess de boro, com destaque para a concentração $15 \mathrm{mM} \cdot \mathrm{L}^{-1}$ de cálcio cuja produção de massa fresca superou as demais.

Estas informações corroboram com os estudos de Gimenes et al. (1990), que mencionam acréscimos significativos na produção e na altura de plantas de alface cultivadas sob concentrações crescentes de boro.

Diversos autores concordam que em casos de deficiência por boro ou cálcio, o crescimento anormal ou retardado da planta é um sintoma comum (Pilbean \& Kirkby, 1983; Mengel \& Kirkby, 1987; Silveira et al., 1995a; Hu \& Brown, 1997; Trevizam 2001). Ao comparar estes dados com o tamanho dos calos (Figura 4), podemos notar que existe uma correlação positiva entre o menor conteúdo de massa fresca, o reduzido tamanho do calo e a omissão do boro e do cálcio no meio de cultura.

No entanto não foi possível caracterizar este mesmo padrão de comportamento a medida que as concentrações tornaram-se crescentes. Alguns autores relatam que altas concentraçõess de cálcio são capazes de atenuar, ou até mesmo impedir, os efeitos da 
toxidez por boro sobre organismos vegetais (Eck \& Campbell, 1962; Marschner, 1995). Desta forma podemos supor que sob altas concentrações do macronutriente a ação tóxica do boro tenha sido minimizada, gerando um crescimento promissor das estruturas calogênicas.

Os aspectos da morfologia externa (Figura 1 e 2 ) mostraram também uma desestruturação dos calos mantidos sob concentrações deficientes do micro e macronutriente, denotando um menor crescimento e decréscimos nos conteúdos de massa fresca.

No período de análise de 31 dias de cultivo, para as curvas representativas da variação da massa fresca (Figura 17) também verificou-se uma influência marcante da disponibilidade de boro e sua interação com o cálcio, sobre este parâmetro de avaliação. De acordo com estes dados, observou-se que a maior concentração de boro $\left(200 \mu \mathrm{M}_{\mathrm{L}}{ }^{-1}\right)$ com 3,75 mM.L ${ }^{-1}$ de cálcio resultou na maior produção de massa fresca, enquanto 0 $\mu \mathrm{M} . \mathrm{L}^{-1}$ de boro e $0 \mathrm{mM} . \mathrm{L}^{-1}$ de cálcio, produziram a menor quantidade de massa fresca.

Nas concentrações $0,7,5$ e $15 \mathrm{mM} . \mathrm{L}^{-1}$ de cálcio notou-se que o acréscimo da concentração de boro a partir de $50 \mu \mathrm{M} . \mathrm{L}^{-1}$ foi capaz de induzir uma menor produção de massa fresca. François (1988) também verificaram a redução de $25 \%$ dos pesos médios total e comercial, em alface com o aumento da concentração de boro.

Entretanto nas concentrações 3,75 e 11,25 mM.L ${ }^{-1}$ de cálcio, o acúmulo de massa fresca foi diretamente proporcional ao acréscimo da concentração de boro no meio de cultura.

Estas variações são esperadas em cultivos in vitro, uma vez que o meio de cultura é um dos fatores que mais influencia o desenvolvimento do material cultivado, determinando também o seu estado nutricional. A presença, a concentração e as interrelações entre os nutrientes determinam a expressão do máximo crescimento vegetativo. Esses fatores no entanto, variam conforme a espécie cultivada e o meio em que se encontram.

Ao se comparar as curvas representativas do conteúdo de massa fresca nos dois períodos pode-se verificar a interferência do tempo de cultivo na quantificação desta 
variável. Calos mantidos por mais tempo in vitro se caracterizam por um menor conteúdo de massa fresca. Slocum et al. (1983) afirmam que a planta cresce até atingir um ponto
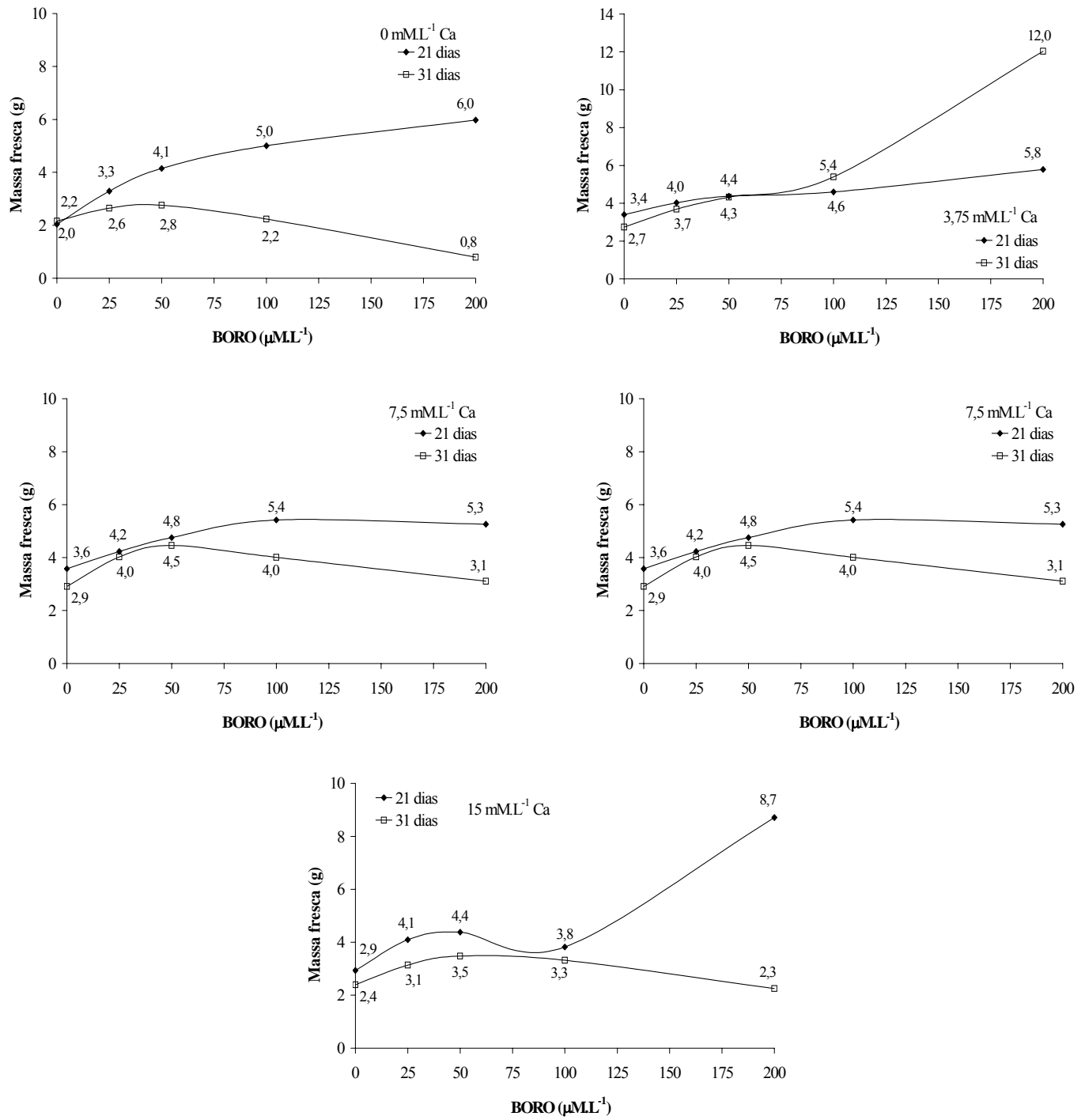
Figura 17 - Quantidade de massa fresca (gramas) de calos E. urophylla avaliada aos 21 e 31 dias de cultivo in vitro em função de diferentes concentrações de boro em determinadas concentrações de cálcio no meio de cultura

máximo de acúmulo de massa sendo que após este período, os níveis de crescimento tornam-se decrescentes, diminuindo assim a taxa de crescimento.

Estes dados também podem ser visualizados nas análises da morfologia externa e interna dos calos (respectivamente, Figuras 2 E e 14 B) que apresentaram a interferência de concentrações de boro e cálcio aos 21 e 31 dias. Através destas Figuras foi possível verificar que tempos de cultivo mais longos, foram responsáveis por processos oxidativos, que interferiram na conformação celular e desenvolvimento dos calos de $E$. urophylla.

\subsubsection{Avaliação de massa fresca em função das concentrações de cálcio com diferentes concentrações de boro aos 21 e 31 dias de cultivo in vitro}

As Tabelas 9 e 10 apresentam os modelos de regressão ajustados para a variação da concentração de cálcio dentro de boro, respectivamente aos 21 e 31 dias para a variável massa fresca de calos.

As curvas de regressão referentes à variável massa fresca avaliada aos 21 dias de cultivo em função das concentrações cálcio com diferentes concentrações de boro estão expressas na Tabela 9. Observou-se que os modelos que melhor se ajustaram as diferentes concentrações de cálcio foram os modelos de regressão cúbica, sendo todos significativos a $1 \%$ pelo teste $\mathrm{F}$ da análise da variância da regressão. Apenas para as concentrações 100 e $200 \mu \mathrm{M} . \mathrm{L}^{-1}$ de boro, o modelo não se ajustou perfeitamente, pois apresentaram um $\mathrm{R}^{2}$ de 0,64 e 0,54 , respectivamente, apesar de terem sido significativos. 
Tabela 9. Equações de regressão correspondentes às concentrações de cálcio $(\mathrm{Ca})$, em mM.L $L^{-1}$, dentro de cada concentrações de boro (B), em $\mu \mathrm{M} \cdot \mathrm{L}^{-1}$, no meio de cultura, para a característica massa fresca (g) de calos de E. urophylla avaliada aos 21 dias de cultivo in vitro

\begin{tabular}{lccc}
\hline & \multicolumn{1}{c}{ Equação } & $\mathrm{R}^{2}$ & $\mathrm{P}<\mathrm{F}$ \\
\hline Ca dentro de B 0 & $\hat{\mathrm{Y}}=2,1193+0,6215 \mathrm{x}-0,0684 \mathrm{x}^{2}+0,0021 \mathrm{x}^{3}$ & 0,99 & 0,000 \\
Ca dentro de B 25 & $\hat{\mathrm{Y}}=3,0820+0,2435 \mathrm{x}-0,0238 \mathrm{x}^{2}+0,0006 \mathrm{x}^{3}$ & 0,96 & 0,000 \\
Ca dentro de B 50 & $\hat{\mathrm{Y}}=4,3040+0,2367 \mathrm{x}-0,0279 \mathrm{x}^{2}+0,0009 \mathrm{x}^{3}$ & 0,99 & 0,000 \\
Ca dentro de B 100 & $\hat{\mathrm{Y}}=4,6147+0,2898 \mathrm{x}-0,0514 \mathrm{x}^{2}+0,0015 \mathrm{x}^{3}$ & 0,64 & 0,000 \\
Ca dentro de B 200 & $\hat{\mathrm{Y}}=4,3110+0,3857 \mathrm{x}-0,0514 \mathrm{x}^{2}+0,0018 \mathrm{x}^{3}$ & 0,54 & 0,000 \\
\hline
\end{tabular}

As curvas de regressão referentes à variável massa fresca avaliada aos 31 dias de cultivo em função das concentrações de cálcio com diferentes concentrações de boro estão expressas na Tabela 10. Observou-se que os modelos que melhor se ajustaram as diferentes concentraçõess de cálcio foram os modelos de regressão cúbica, sendo todos significativos a $1 \%$ pelo teste $\mathrm{F}$ da análise da variância da regressão. Os modelos apresentados se ajustaram perfeitamente aos dados, uma vez que apresentaram um $\mathrm{R}^{2}$ superior a 0,88 .

Tabela 10. Equações de regressão correspondentes às concentrações de cálcio $(\mathrm{Ca})$, em mM.L $L^{-1}$, dentro de cada concentrações de boro (B), em $\mu \mathrm{M} . \mathrm{L}^{-1}$, no meio de cultura, para a característica massa fresca (g) de calos de E. urophylla avaliada aos 31 dias de cultivo in vitro

Equação $\quad \mathrm{R}^{2} \quad \mathrm{P}<\mathrm{F}$




\begin{tabular}{lllll}
\hline Ca dentro de B 0 & $\hat{Y}=2,0568+0,2203 x-0,0198 x^{2}+0,0004 x^{3}$ & 0,99 & 0,000 \\
Ca dentro de B 25 & $\hat{Y}=2,9649+0,4487 x-0,0378 x^{2}+0,0006 x^{3}$ & 0,99 & 0,000 \\
Ca dentro de B 50 & $\hat{Y}=2,4412+0,6199 x-0,0829 x^{2}+0,0031 x^{3}$ & 0,88 & 0,000 \\
Ca dentro de B 100 & $\hat{Y}=2,4418+0,6225 x-0,0834 x^{2}+0,0031 x^{3}$ & 0,88 & 0,000 \\
Ca dentro de B 200 & $\hat{Y}=2,3269+0,0655 x+0,0014 x^{2}-0,0003 x^{3}$ & 0,94 & 0,000 \\
\hline
\end{tabular}

Observou-se um comportamento regular para as curvas representativas da quantidade de massa fresca, avaliada aos 21 dias de cultivo, de acordo com a variação da concentração de cálcio para as diferentes concentrações de boro, exceto na concentração $100 \mu \mathrm{M} . \mathrm{L}^{-1}$ de boro (Figura 18). Para esta concentração (100 $\mu \mathrm{M} . \mathrm{L}^{-1}$ de boro), o aumento da concentração do cálcio no meio de cultura induziu nitidamente um menor teor de matéria fresca.

De acordo com os dados obtidos o maior valor de massa fresca foi observado para as interações $100 \mu \mathrm{M} . \mathrm{L}^{-1}$ de boro com 3,75 mM.L ${ }^{-1}$ de cálcio, $200 \mu \mathrm{M} . \mathrm{L}^{-1}$ de boro com 3,75 e 7,5 mM.L $\mathrm{L}^{-1}$ de cálcio.

Já o menor conteúdo de massa fresca de calos de E. urophylla avaliada aos 21 dias de cultivo em função das concentraçõess de cálcio com diferentes concentraçõess de boro, foi encontrado para a omissão do micro e do macronutriente no meio de cultura. Estes dados corroboram com as análises anteriores (Figura 17), onde verificou-se que as maiores concentrações de boro forma responsáveis pelos maiores incrementos da massa seca em calos e a ausência conjunta dos nutrientes determinaram menores massas frescas.

Analisando as curvas representativas da variação da massa fresca avaliada aos 31 dias de cultivo (Figura 18) verificou-se que a maior produção de massa fresca foi verificada em 7,5 mM.L $\mathrm{L}^{-1}$ de cálcio com $25 \mu \mathrm{M} . \mathrm{L}^{-1}$ de boro, enquanto a menor produção de massa fresca foi observada na concentração $0 \mu \mathrm{mM} \cdot \mathrm{L}^{-1}$ de cálcio e $100 \mu \mathrm{M} . \mathrm{L}^{-1}$ de boro.

Estes dados demonstram os calos cultivados por 31 dias apresentam exigências nutricionais distintas para um crescimento ótimo. Marschner (1995) afirma que o aumento da concentração de um nutriente específico, pode estimular o crescimento de 
células e tecidos, mas ao mesmo tempo pode levar a processos de deficiência devido aos efeitos de diluição.

Borgatto et al (2002) afirmam que a calogênese em espécies de Chrysanthemum foi afetada por concentrações de cálcio presentes no meio de cultura em função do período de cultivo, e desta forma mostrou que o peso fresco nesta espécie foi menor a medida que concentrações de cálcio eram acrescida em um período mais longos de cultivo in vitro.
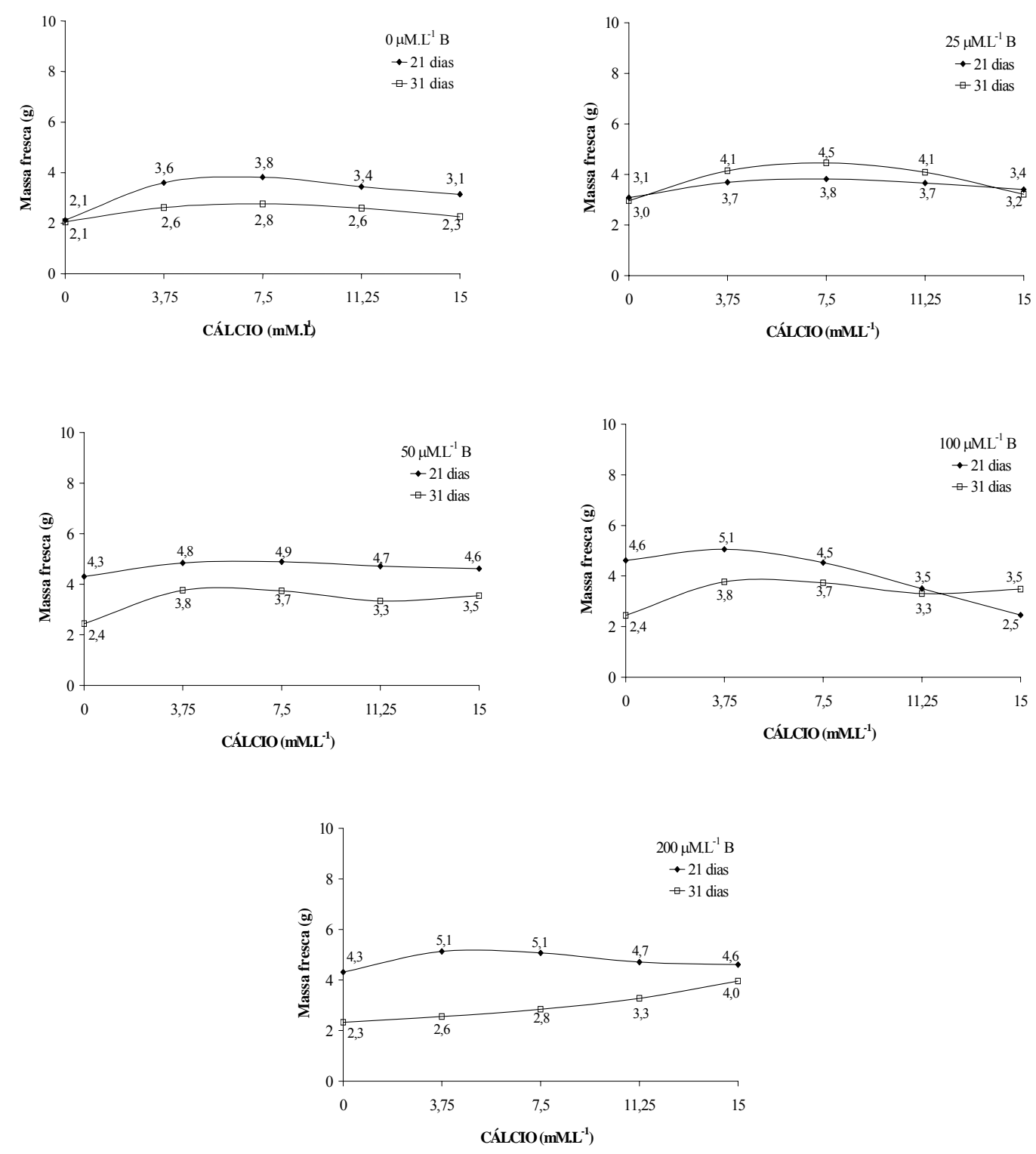
Figura 188 - Quantidade de massa fresca (gramas) de calos E. urophylla avaliada aos 21 e 31 dias de cultivo in vitro em função de diferentes concentrações de cálcio em determinadas concentrações de boro no meio de cultura

\subsubsection{Avaliação de massa seca em função das concentrações de boro com diferentes concentrações de cálcio aos 21 e 31 dias de cultivo in vitro}

As Tabelas 11 e 12 apresentam os modelos de regressão ajustados para a variação da concentração de boro dentro de cálcio, respectivamente aos 21 e 31 dias para a variável massa seca de calos.

As equações de regressão referentes à variável massa seca avaliada aos 21 dias de cultivo em função das concentrações de boro com diferentes concentrações de cálcio estão expressas na Tabela 11. Notou-se que os modelos que melhor se ajustaram as diferentes concentrações de cálcio foram os de regressão quadrática, com exceção da concentração 7,50 mM.L $\mathrm{L}^{-1}$ de cálcio, cujo modelo de melhor ajuste foi o de terceira ordem, sendo todos significativos a 1\% pelo teste $\mathrm{F}$ da análise da variância da regressão, e apresentando coeficientes de determinação acima de 0,90 .

Tabela 11. Equações de regressão correspondentes às concentrações de boro (B), em $\mu \mathrm{M} . \mathrm{L}^{-1}$, dentro de cada concentração de cálcio $(\mathrm{Ca})$, em mM.L ${ }^{-1}$, no meio de cultura, para a característica massa seca $(\mathrm{mg})$ de calos de E. urophylla avaliada aos 21 dias de cultivo in vitro

\begin{tabular}{llcc}
\hline & \multicolumn{1}{c}{ Equação } & $\mathrm{R}^{2}$ & $\mathrm{P}<\mathrm{F}$ \\
\hline B dentro de Ca 0 & $\hat{\mathrm{Y}}=122,7851+1,7259 \mathrm{x}-0,0094 \mathrm{x}^{2}$ & 0,99 & 0,000 \\
B dentro de Ca 3,75 & $\hat{\mathrm{Y}}=134,0699+1,9256 \mathrm{x}-0,0102 \mathrm{x}^{2}$ & 0,93 & 0,000 \\
B dentro de Ca 7,50 & $\hat{\mathrm{Y}}=144,46+4,6147 \mathrm{x}-0,0521 \mathrm{x}^{2}+0,0001 \mathrm{x}^{3}$ & 0,92 & 0,000 \\
B dentro de Ca 11,25 & $\hat{\mathrm{Y}}=146,1000+1,6917 \mathrm{x}-0,0083 \mathrm{x}^{2}$ & 0,95 & 0,000 \\
B dentro de Ca 15 & $\hat{\mathrm{Y}}=126,5760+2,0583 \mathrm{x}-0,0109 \mathrm{x}^{2}$ & 0,94 & 0,000 \\
\hline
\end{tabular}


As equações de regressão referentes à variável massa seca avaliada aos 31 dias de cultivo em função das concentrações de boro com diferentes concentrações de cálcio estão expressas na Tabela 12.

Conferindo estes dados notamos que os modelos que melhor se ajustaram as diferentes concentraçõess de cálcio foram os de regressão cúbica, com exceção da concentração $15 \mathrm{mM} . \mathrm{L}^{-1}$ de cálcio, cujo modelo de melhor ajuste foi o de segunda ordem, sendo todos significativos a 1\% pelo teste $\mathrm{F}$ da análise da variância da regressão. Semelhante ao que ocorreu com os modelos de regressão para massa seca avaliada aos 21 dias, os modelos de regressão aos 31 dias estão apresentando um bom ajuste, com $\mathrm{R}^{2}$ superiores a $86 \%$.

Tabela 12. Equações de regressão correspondentes às concentrações de boro (B), em $\mu \mathrm{M} . \mathrm{L}^{-1}$, dentro de cada concentração de cálcio $(\mathrm{Ca})$, em mM.L ${ }^{-1}$, no meio de cultura, para a característica massa seca de calos avaliada aos 31 dias de cultivo in vitro

\begin{tabular}{llcc}
\hline & \multicolumn{1}{c}{ Equação } & $\mathrm{R}^{2}$ & $\mathrm{P}<\mathrm{F}$ \\
\hline B dentro de Ca 0 & $\hat{\mathrm{Y}}=108,8318+1,6995 \mathrm{x}-0,0066 \mathrm{x}^{2}-0,1 \mathrm{E}-4 \mathrm{x}^{3}$ & 0,99 & 0,000 \\
B dentro de Ca 3,75 & $\hat{\mathrm{Y}}=113,4915+2,7369 \mathrm{x}-0,0207 \mathrm{x}^{2}+0,3 \mathrm{E}-4 \mathrm{x}^{3}$ & 0,92 & 0,000 \\
B dentro de Ca 7,50 & $\hat{\mathrm{Y}}=134,1042+4,2197 \mathrm{x}-0,0446 \mathrm{x}^{2}+0,0001 \mathrm{x}^{3}$ & 0,98 & 0,000 \\
B dentro de Ca 11,25 & $\hat{\mathrm{Y}}=113,4630+3,5597 \mathrm{x}-0,0386 \mathrm{x}^{2}+0,0001 \mathrm{x}^{3}$ & 0,86 & 0,000 \\
B dentro de Ca 15 & $\hat{\mathrm{Y}}=111,2277+2,0988 \mathrm{x}-0,0108 \mathrm{x}^{2}$ & 0,97 & 0,000 \\
\hline
\end{tabular}

De acordo com a Figura 19, aos 21 dias de cultivo in vitro foi possível observar o menor conteúdo de massa seca na concentração $200 \mu \mathrm{M} . \mathrm{L}^{-1}$ de boro com $0 \mathrm{mM} . \mathrm{L}^{-1}$ de cálcio, enquanto a maior quantidade foi verificada para a concentração $50 \mu \mathrm{M} \cdot \mathrm{L}^{-1}$ de boro e 7,5 mM.L.-1 de cálcio.

O crescimento da massa seca foi marcadamente influenciado pela disponibilidade de variação das concentrações boro dentro de cada concentração de cálcio. As concentrações extremas do micronutriente para todas as concentrações de 
cálcio induziram uma menor produção de massa seca de calos de E. urophylla avaliadas aos 21 dias de cultivo in vitro. Estas informações se contrapõem a análises realizadas para os teores de massa fresca no mesmo (Figura 17), ou seja o acúmulo de massa seca foi inversamente proporcional as concentrações de boro no meio de cultura.

De acordo com os dados obtidos, os maiores conteúdos de massa seca se relacionaram com as concentrações 50 e $100 \mu \mathrm{M} . \mathrm{L}^{-1}$ de boro, independente das concentrações de cálcio. Estes resultados corroboram com as afirmações de Trevizam (2001) que estudando calos de E. urophylla observou uma maior produção de massa seca na concentração $50 \mu \mathrm{M} . \mathrm{L}^{-1}$ de boro e uma queda na produção ao se utilizar 200 $\mu \mathrm{M} . \mathrm{L}^{-1}$ de boro no meio de cultura.

Diversos trabalhos identificam os efeitos da deficiência de boro no decréscimo da massa seca de espécies de Eucalyptus (Rocha Filho et al. 1978; Carvalho et al., 1980; Silveira et al. 1996; Sgarbi et al., 1999), no entanto, a interferência destas interações sobre a massa seca de plantas cultivadas sob concentrações excessivas do macro e do micronutriente não são comuns.

Analisando as curvas representativas da massa seca de calos E. urophylla aos 31 dias de cultivo in vitro verificou-se que a melhor resposta para a produção de massa seca foi observada na concentração $50 \mu \mathrm{M} . \mathrm{L}^{-1}$ de boro e $7,5 \mathrm{mM} . \mathrm{L}^{-1}$ de cálcio enquanto as menores quantidades deram-se nas combinações $200 \mu \mathrm{M} \cdot \mathrm{L}^{-1}$ de boro e $11,25 \mathrm{mM} . \mathrm{L}^{-1}$ de cálcio (Figura 19). Estes resultados se assemelham aos obtidos para o período de cultivo de 21 dias, confirmando a essencialidade da concentração $50 \mu \mathrm{M} . \mathrm{L}^{-1}$ de boro no incremento da massa seca de calos de E. urophylla.

A absorção de altas concentrações de boro pelos calos, provavelmente ocasionou danos ao funcionamento celular, levando à redução na organização dos tecidos, que resultou no decréscimo de massa seca, como resposta a prováveis sintomas de estresse.

Desta forma podemos inferir que a produção da massa seca tanto aos 31 como aos 21 dias de cultivo in vitro foi marcadamente influenciado pela disponibilidade de variação das concentrações boro dentro de cada concentração de cálcio, demonstrando a importância da interação boro e cálcio no desenvolvimento dos calos. 
Ao se relacionar estes dados com as características da morfologia externa (Figura 3) e o tamanho dos calos (Figura 1), percebeu-se que altas concentrações do
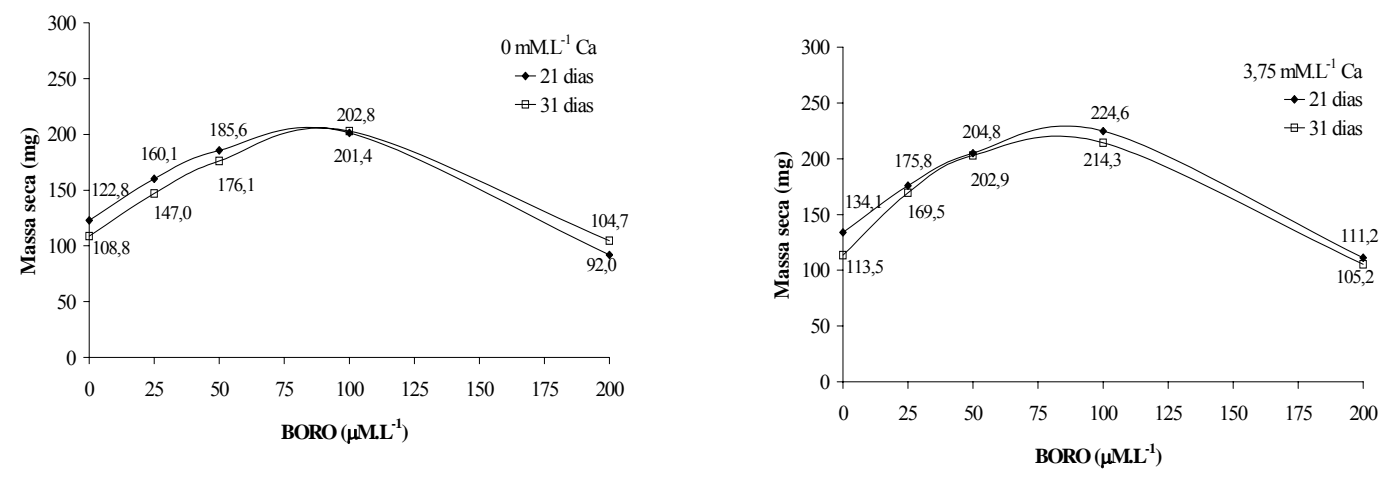

micronutriente no meio de cultura foram determinantes para o decréscimo de todas estas variáveis analisadas.

Figura 19 - Quantidade de massa seca (miligramas) de calos E. urophylla avaliada aos 21 e 31 dias de cultivo in vitro em função de diferentes concentrações de boro em determinadas concentrações de cálcio no meio de cultura

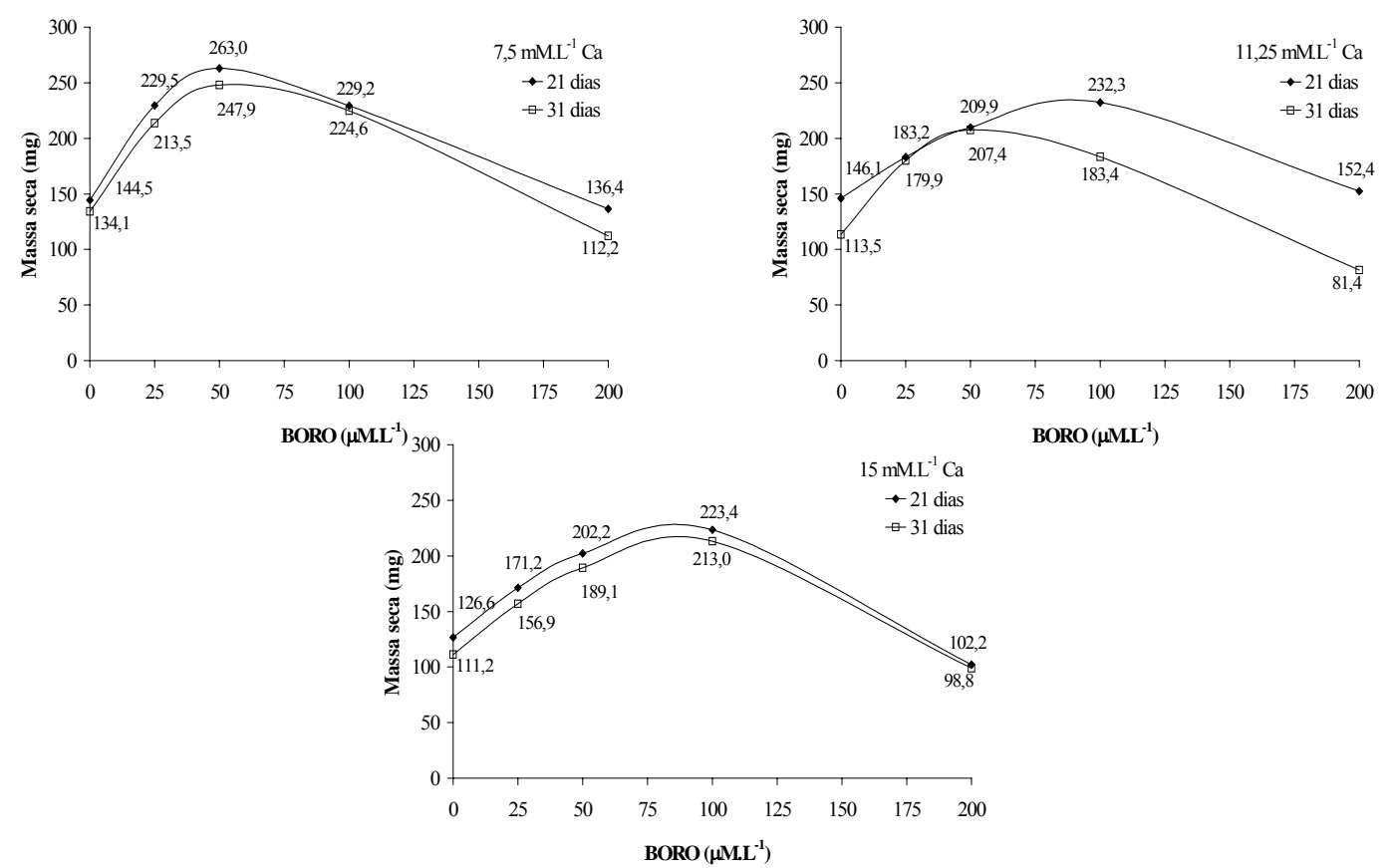




\subsubsection{Avaliação de massa seca em função das concentrações de cálcio com diferentes concentrações de boro aos 21 e 31 dias de cultivo in vitro}

As Tabelas 13 e 14 apresentam os modelos de regressão ajustados para a variação da concentração de cálcio dentro de boro, respectivamente aos 21 e 31 dias para a variável massa seca de calos.

As equações de regressão referentes à variável massa seca avaliada aos 21 dias de cultivo in vitro em função das concentrações de cálcio com diferentes concentrações de boro estão expressas na Tabela 13. Observou-se que os modelos que melhor se ajustaram as diferentes concentraçõess de cálcio foram os modelos de regressão cúbica, sendo todos significativos a $1 \%$ pelo teste $\mathrm{F}$ da análise da variância da regressão. Os modelos apresentados se ajustaram perfeitamente aos dados, exceto em $50 \mu \mathrm{M} . \mathrm{L}^{-1}$ de boro que apresentou um $\mathrm{R}^{2}$ de 0,66 .

Tabela 13. Equações de regressão correspondentes às concentrações de cálcio $(\mathrm{Ca})$, em mM.L ${ }^{-1}$, dentro de cada concentração de boro (B), em $\mu \mathrm{M} . \mathrm{L}^{-1}$, no meio de cultura, para a característica massa seca $(\mathrm{mg})$ de calos de E. urophylla avaliada aos 21 dias de cultivo in vitro

\begin{tabular}{llcc}
\hline & \multicolumn{1}{c}{ Equação } & $\mathrm{R}^{2}$ & $\mathrm{P}<\mathrm{F}$ \\
\hline Ca dentro de B 0 & $\hat{\mathrm{Y}}=123,4933+6,0921 \mathrm{x}-0,3855 \mathrm{x}^{2}$ & 0,89 & 0,002 \\
Ca dentro de B 25 & $\hat{\mathrm{Y}}=148,1490+11,5312 \mathrm{x}-0,7213 \mathrm{x}^{2}$ & 0,76 & 0,000 \\
Ca dentro de B 50 & $\hat{\mathrm{Y}}=188,9689+16,8599 \mathrm{x}-1,0246 \mathrm{x}^{2}$ & 0,66 & 0,000 \\
Ca dentro de B 100 & $\hat{\mathrm{Y}}=201,4555+4,9405 \mathrm{x}-0,2689 \mathrm{x}^{2}$ & 0,99 & 0,026 \\
Ca dentro de B 200 & $\hat{\mathrm{Y}}=93,6447+0,2767 \mathrm{x}+1,5732 \mathrm{x}^{2}-0,1032 \mathrm{x}^{3}$ & 0,98 & 0,001 \\
\hline
\end{tabular}

As equações de regressão referentes à variável massa seca avaliada aos 31 dias de cultivo in vitro em função das concentrações de cálcio com diferentes concentraçõess de boro estão expressas na Tabela 14. Observou-se que os modelos que melhor se ajustaram as diferentes concentrações de boro foram os de regressão cúbica, sendo todos 
significativos a $1 \%$ pelo teste $\mathrm{F}$ da análise da variância da regressão. Somente para as concentrações 25 e $50 \mu \mathrm{M} . \mathrm{L}^{-1}$ de boro, o modelo não se ajustou perfeitamente, pois apresentaram respectivamente um coeficiente de determinação de 0,53 e 0,52, , apesar de terem sido significativos.

Tabela 14. Equações de regressão correspondentes às concentrações de cálcio $(\mathrm{Ca})$, em mM.L ${ }^{-1}$, dentro de cada concentração de boro (B), em $\mu \mathrm{M} \cdot \mathrm{L}^{-1}$, no meio de cultura, para a característica massa seca $(\mathrm{mg})$ de calos de E. urophylla avaliada aos 31 dias de cultivo in vitro

\begin{tabular}{lccc}
\hline & \multicolumn{1}{c}{ Equação } & $\mathrm{R}^{2}$ & $\mathrm{P}<\mathrm{F}$ \\
\hline Ca dentro de B 0 & $\hat{\mathrm{Y}}=108,2527+6,8005 \mathrm{x}-0,5472 \mathrm{x}^{2}+0,0079 \mathrm{x}^{3}$ & 0,81 & 0,000 \\
Ca dentro de B 25 & $\hat{\mathrm{Y}}=139,4765+9,4677 \mathrm{x}-0,5366 \mathrm{x}^{2}-0,0059 \mathrm{x}^{3}$ & 0,53 & 0,000 \\
Ca dentro de B 50 & $\hat{\mathrm{Y}}=176,2102+20,5508 \mathrm{x}-1,5684 \mathrm{x}^{2}+0,0198 \mathrm{x}^{3}$ & 0,96 & 0,000 \\
Ca dentro de B 100 & $\hat{\mathrm{Y}}=197,3246+13,9970 \mathrm{x}-2,5030 \mathrm{x}^{2}+0,1076 \mathrm{x}^{3}$ & 0,52 & 0,000 \\
Ca dentro de B 200 & $\hat{\mathrm{Y}}=91,3323+7,0306 \mathrm{x}-0,7365 \mathrm{x}^{2}+0,0199 \mathrm{x}^{3}$ & 0,98 & 0,000 \\
\hline
\end{tabular}

Aos 21 dias de cultivo in vitro observou-se um comportamento regular para as curvas representativas da quantidade de massa seca de acordo com a variação da concentração de cálcio para as diferentes concentrações de boro (Figura 20). De acordo com os dados obtidos podemos constatar uma maior produção de massa seca na concentração 7,5 mM.L $\mathrm{L}^{-1}$ de cálcio com $50 \mu \mathrm{M} \cdot \mathrm{L}^{-1}$ de boro, ao passo que a omissão de boro com a maior concentração de cálcio indicaram a menor produção de massa seca.

Malavolta et al. (1997) afirmam que concentrações deficientes de cálcio ou boro determinam baixo desenvolvimento vegetal, interferindo em diversos processos fisiológicos. Arruda et al. (2001), ao analisarem calos cultivados em diferentes concentrações de cálcio em meio de cultura, verificaram grandes desordens celulares, com presença de células colapsadas e desagregadas ao se omitir o macronutriente. 
Concentrações crescentes do macronutriente não mostraram grandes variações nas curvas representativas, no entanto ao se observar o incremento da concentração de boro conferimos um aumento na produção de massa seca de calos até a concentração $100 \mu \mathrm{M} . \mathrm{L}^{-1}$.

Observou-se um comportamento regular para as curvas representativas da quantidade de massa seca, avaliada aos 31 dias (Figura 20). Apenas na concentração 50 $\mu \mathrm{M} . \mathrm{L}^{-1}$ de boro, detectou-se uma curva ascendente para o conteúdo de massa seca até a concentração 7,5 mM.L ${ }^{-1}$ de cálcio, que coincidiu com o maior índice de produção e mostrou decréscimos posteriores para concentraçõess superiores a 7,5 mM.L $\mathrm{L}^{-1}$ de cálcio.

Comparativamente, as curvas de cálcio dentro de boro para os dois períodos de cultivo apresentaram comportamentos semelhantes, indicando uma pequena interferência do cálcio na determinação da massa seca. Embora os padrões das curvas tenham sido semelhantes, verificou-se que calos cultivados por períodos mais longos de cultivo (31 dias) determinaram uma menor produção de massa seca.

Conforme Ingestad et al. (1995), o equilíbrio encontrado em alguns tratamentos indica que possivelmente existe um equilíbrio entre a taxa de absorção de nutrientes e a conversão em massa vegetal seca. A redução no incremento de material vegetal seco pode estar associada a um esgotamento do meio de cultura e das condições favoráveis de crescimento da espécie, já que as condições ambientais e a necessidade específica de nutrientes para cada espécie podem estar influenciando o seu crescimento. 

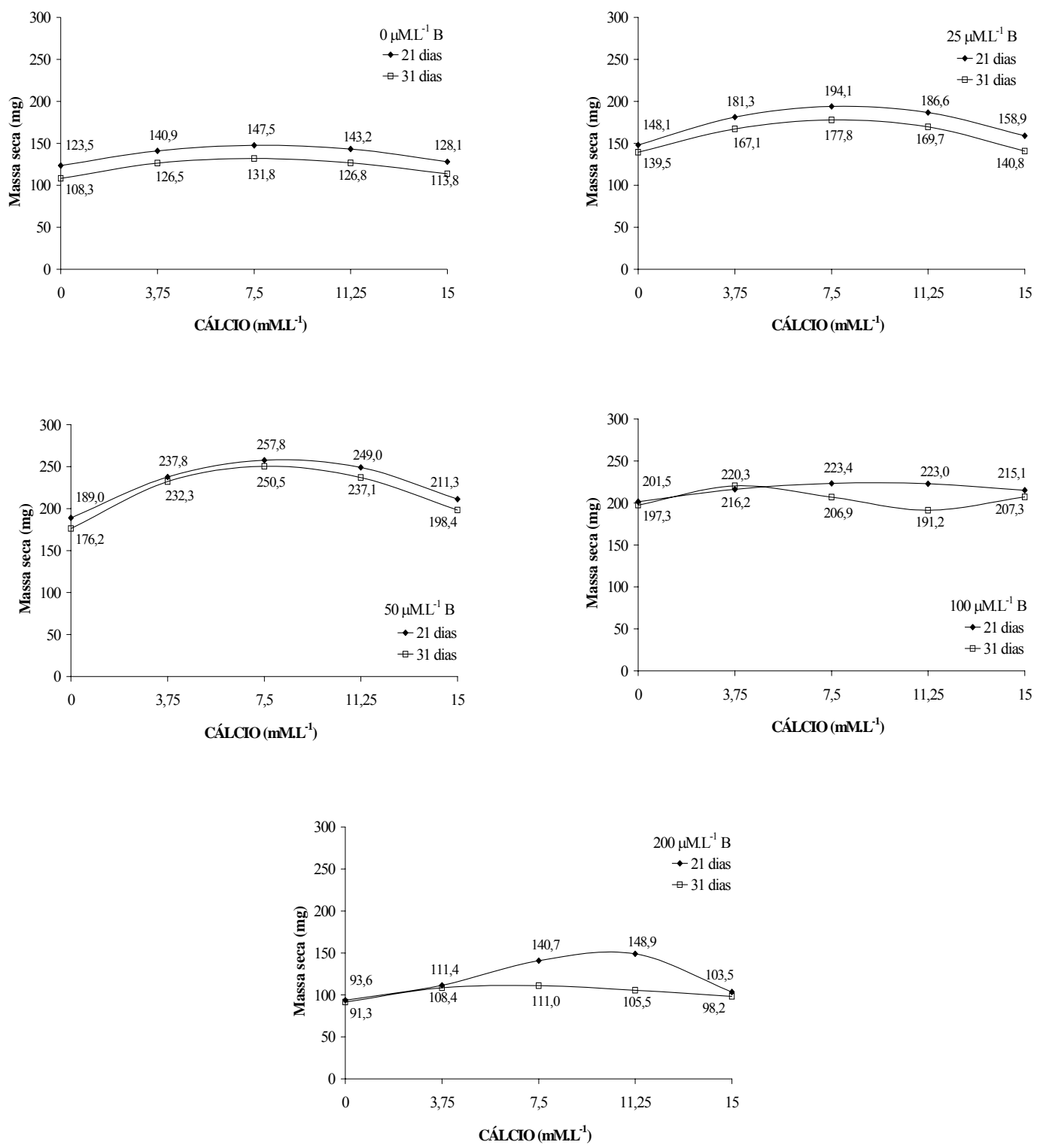

Figura 20 - Quantidade de massa seca (miligramas) de calos E. urophylla avaliada aos 21 e 31 dias de cultivo in vitro em função de diferentes concentrações de cálcio em determinadas concentrações de boro no meio de cultura 


\subsubsection{Avaliação dos teores de prolina}

\subsubsection{Avaliação dos teores de prolina em função das concentrações de boro com diferentes concentrações de cálcio aos 21 e 31 dias de cultivo in vitro}

As Tabelas 15 e 16 apresentam os modelos de regressão ajustados para a variação da concentração de boro dentro de cálcio, respectivamente aos 21 e 31 dias para teor de prolina em calos de E. urophylla cultivados in vitro.

Os modelos de regressão referentes à variável prolina avaliada aos 21 dias de cultivo in vitro em função das concentrações de boro com diferentes concentrações de cálcio estão expressos na Tabela 15.

Os modelos de regressão referentes a variável prolina avaliada aos 21 dias de cultivo in vitro em função das concentrações de boro com diferentes concentrações de cálcio que melhor se ajustaram foram os modelos de regressão cúbica, sendo todos significativos a $1 \%$ pelo teste $\mathrm{F}$ da análise da variância da regressão. Somente para as concentrações 3,75 e 11,5 mM.L $\mathrm{L}^{-1}$ de cálcio, o modelo não se ajustou perfeitamente, pois apresentaram um $\mathrm{R}^{2}$ de 0,18 e 0,68 , respectivamente, apesar de terem sido significativos.

Tabela 15. Equações de regressão correspondentes às concentrações de boro (B), em $\mu \mathrm{M} . \mathrm{L}^{-1}$, dentro de cada concentração de cálcio $(\mathrm{Ca}), \mathrm{em} \mathrm{mM} \cdot \mathrm{L}^{-1}$, no meio de cultura, para a característica prolina ( $\mu \mathrm{g} / \mathrm{g}$ de Massa Fresca) em calos de $E$ urophylla avaliada aos 21 dias de cultivo in vitro

\begin{tabular}{lccc}
\hline & \multicolumn{1}{c}{ Equação } & $\mathrm{R}^{2}$ & $\mathrm{P}<\mathrm{F}$ \\
\hline B dentro de Ca 0 & $\hat{\mathrm{Y}}=82,2066+0,8652 \mathrm{x}-0,0157 \mathrm{x}^{2}+0,00006 \mathrm{x}^{3}$ & 0,81 & 0,000 \\
B dentro de Ca 3,75 & $\hat{\mathrm{Y}}=106,1228-0,6627 \mathrm{x}+0,1272 \mathrm{x}^{2}-0,00005 \mathrm{x}^{3}$ & 0,18 & 0,000 \\
B dentro de Ca 7,50 & $\hat{\mathrm{Y}}=115,2448-2,5624 \mathrm{x}+0,0357 \mathrm{x}^{2}-0,0001 \mathrm{x}^{3}$ & 0,97 & 0,000 \\
B dentro de Ca 11,5 & $\hat{\mathrm{Y}}=92,1791+1,5365 \mathrm{x}-0,0294 \mathrm{x}^{2}+0,0001 \mathrm{x}^{3}$ & 0,68 & 0,000 \\
B dentro de Ca 15 & $\hat{\mathrm{Y}}=181,3770-3,8054 \mathrm{x}+0,0401 \mathrm{x}^{2}-0,0001 \mathrm{x}^{3}$ & 0,98 & 0,000 \\
\hline
\end{tabular}


Observando-se a Tabela 16, pode-se notar os modelos de regressão referentes à prolina avaliada aos 31 dias de cultivo em função das concentrações de boro com diferentes concentrações de cálcio. Nota-se também que os modelos cúbico e quadrático apresentaram melhor ajuste as diferentes concentrações de cálcio, sendo todos significativos a $1 \%$ pelo teste $\mathrm{F}$ da análise da variância da regressão, com exceção da concentração 7,50 mM.L $\mathrm{L}^{-1}$ de cálcio que não apresentou ajuste a nenhum modelo de regressão, enquanto as concentrações 0 e 15 mM.L ${ }^{-1}$ de cálcio, embora tenham modelos de regressão significativos, apresentaram coeficientes de determinação baixos (respectivamente $\mathrm{R}^{2}$ de 0,46 e 0,64 ).

Tabela 16. Equações de regressão correspondentes às concentrações de boro (B), em $\mu \mathrm{M} . \mathrm{L}^{-1}$, dentro de cada concentração de cálcio $(\mathrm{Ca})$, em mM.L ${ }^{-1}$, no meio de cultura, para a característica prolina ( $\mu \mathrm{g} / \mathrm{g}$ de Massa Fresca) em calos de $E$ urophylla avaliada aos 31 dias de cultivo in vitro

\begin{tabular}{llcc}
\hline & \multicolumn{1}{c}{ Equação } & $\mathrm{R}^{2}$ & $\mathrm{P}<\mathrm{F}$ \\
\hline B dentro de Ca 0 & $\hat{\mathrm{Y}}=179,573+1,122 \mathrm{x}-0,0266 \mathrm{x}^{2}+0,00001 \mathrm{x}^{3}$ & 0,46 & 0,005 \\
B dentro de Ca 3,75 & $\hat{\mathrm{Y}}=117,806-0,953 \mathrm{x}+0,0063 \mathrm{x}^{2}$ & 0,85 & 0,000 \\
B dentro de Ca 7,50 & - & - & $\mathrm{ns}$ \\
B dentro de Ca 11,25 & $\hat{\mathrm{Y}}=143,723+1,200 \mathrm{x}-0,0298 \mathrm{x}^{2}+0,0001 \mathrm{x}^{3}$ & 0,99 & 0,001 \\
B dentro de Ca 15 & $\hat{\mathrm{Y}}=84,379+0,6064 \mathrm{x}-0,0028 \mathrm{x}^{2}$ & 0,64 & 0,031
\end{tabular}
ns: não significativo pelo teste $\mathrm{F}$

Através da Figura 21, foi possível constatar aos 21 dias de cultivo in vitro, que a maior produção de prolina ocorreu na ausência de boro em combinação com 15 mM.L $\mathrm{L}^{-1}$ de cálcio, ao passo que $100 \mu \mathrm{M} . \mathrm{L}^{-1}$ de boro e $11,25 \mathrm{mM} \cdot \mathrm{L}^{-1}$ de cálcio determinaram a produção inferior deste aminoácido.

Observou-se também a ocorrência de um acréscimo representativo na quantidade de prolina produzida no calo a partir da concentração $100 \mu \mathrm{M} . \mathrm{L}^{-1}$ de boro, 
principalmente nos calos cultivados sob a concentração $200 \mu \mu \mathrm{M} \cdot \mathrm{L}^{-1}$ de boro combinada com 0 e 7,5 mM.L ${ }^{-1}$ de cálcio. Nas concentrações 7,5 e 15 mM.L -1 $^{-1}$ de cálcio verificou-se aumentos discretos nos teores de prolina a partir da interação com $50 \mu \mathrm{M} . \mathrm{L}^{-1}$ de boro.

O incremento na produção de prolina principalmente em concentrações superiores a $50 \mu \mathrm{M} \cdot \mathrm{L}^{-1}$ de boro não foi verificado apenas para a concentração 3,75 mM.L $\mathrm{L}^{-1}$ de cálcio, fato que determinou um padrão de comportamento distinto em relação as demais interações nutricionais (Figura 21).

Considerando os dados apresentados pela literatura supõe-se que esta divergência no comportamento da produção de prolina durante esta interação seja explicada pelo baixo $\mathrm{R}^{2}$ do modelo ajustado. Diversos trabalhos têm demonstrado uma correlação positiva entre o acúmulo de prolina e a tolerância ao estresse (Jain et al., 1991; Camara et al., 1998; Storey et al., 1993), entretanto, a acumulação de prolina pode ser interpretada também como sintoma de danos causados na planta pelo estresse (Hasegawa et al., 1986; Das et al., 1990).

Supõe-se diante das condições avaliadas, que a ausência de boro e a concentração mais elevada de cálcio foram capazes de determinar uma alta produção de prolina, da mesma forma que concentrações elevadas de boro (Figura 21).

Trevizam (2001), ao analisar calos de E. urophylla em cultivo in vitro verificou que o boro interferia na quantificação de prolina quando eram utilizadas concentrações excessivas ou tóxicas do micronutriente em meio de cultura. A autora também relata um aumento duas vezes superior na produção do aminoácido nestas concentrações.

Bellinger et al. (1991) sugerem que a acumulação de prolina não é um indicador de resistência e sim um indicador de tolerância adquirida, visto que diversos experimentos demonstram que células, calos e somaclones selecionados como tolerantes ao estresse apresentou uma maior acumulação de prolina do que os não adaptados.

Aos 31 dias de cultivo in vitro, pode-se notar que a ausência do cálcio junto com a concentração $25 \mu \mathrm{M} . \mathrm{L}^{-1}$ de boro no meio de cultura, proporcionou o maior conteúdo de prolina, para a variação da concentração de boro dentro das concentrações de cálcio. Já o conteúdo mínimo do referido aminoácido foi verificado na concentração 15 mM.L $\mathrm{L}^{-1}$ 
de cálcio e $0 \mu \mathrm{M} . \mathrm{L}^{-1}$ de boro (Figura 21). Entretanto, deve-se levar em consideração que para essas concentrações de cálcio o modelo não se ajustou perfeitamente, pois estão explicando apenas $46 \%$ e $64 \%$ dos resultados, respectivamente, para 0 e 15 mM.L ${ }^{-1}$ de cálcio.

Com exceção da concentração 3,75 mM.L ${ }^{-1}$ de cálcio, verificou-se um aumento do conteúdo de prolina a partir da concentração de $0 \mu \mathrm{M} . \mathrm{L}^{-1}$ de boro até a concentração $25 \mu \mathrm{M} . \mathrm{L}^{-1}$ de boro, no entanto em concentrações superiores este acréscimo na quantificação do teor do aminoácido não se consolidou.

Registraram-se acréscimos de prolina para a concentração mais alta de boro $\left(200 \mu \mathrm{M} . \mathrm{L}^{-1}\right)$ em combinação com todas as concentrações de cálcio, exceto para $15 \mathrm{mM} . \mathrm{L}^{-1}$ que mostrou correlação negativa para o acúmulo de prolina. De acordo com estes dados pode-se supor que a alta concentração de cálcio seja responsável pela inibição dos efeitos do estresse nutricional causado pela toxidez de boro, com conseqüente interferência nos teores de prolina.

Considerando-se que altos valores de $\mathrm{pH}$ afetam negativamente a absorção de boro, pode-se considerar que o aumento da concentração de cálcio no meio de cultura determinou a redução na disponibilidade de boro aos calos, fato que influenciou diretamente na diminuição do estresse nutricional causado pelo micronutriente com conseqüente diminuição dos teores de prolina.

De acordo com Marschner (1995), o aumento da concentração de um nutriente específico pode estimular o metabolismo celular, mas ele pode também em muitos casos induzir deficiências de outros nutrientes pelo efeito de diluição.

Quanto ao tempo de cultivo, Willadino et al. (1996) obtiveram um maior acúmulo de prolina livre em calos de milho, quando mantiveram estas culturas sob concentrações minerais crescentes e em tempos menores, no entanto este comportamento não pode ser confirmado para todas as concentrações combinadas de boro e cálcio testadas. 

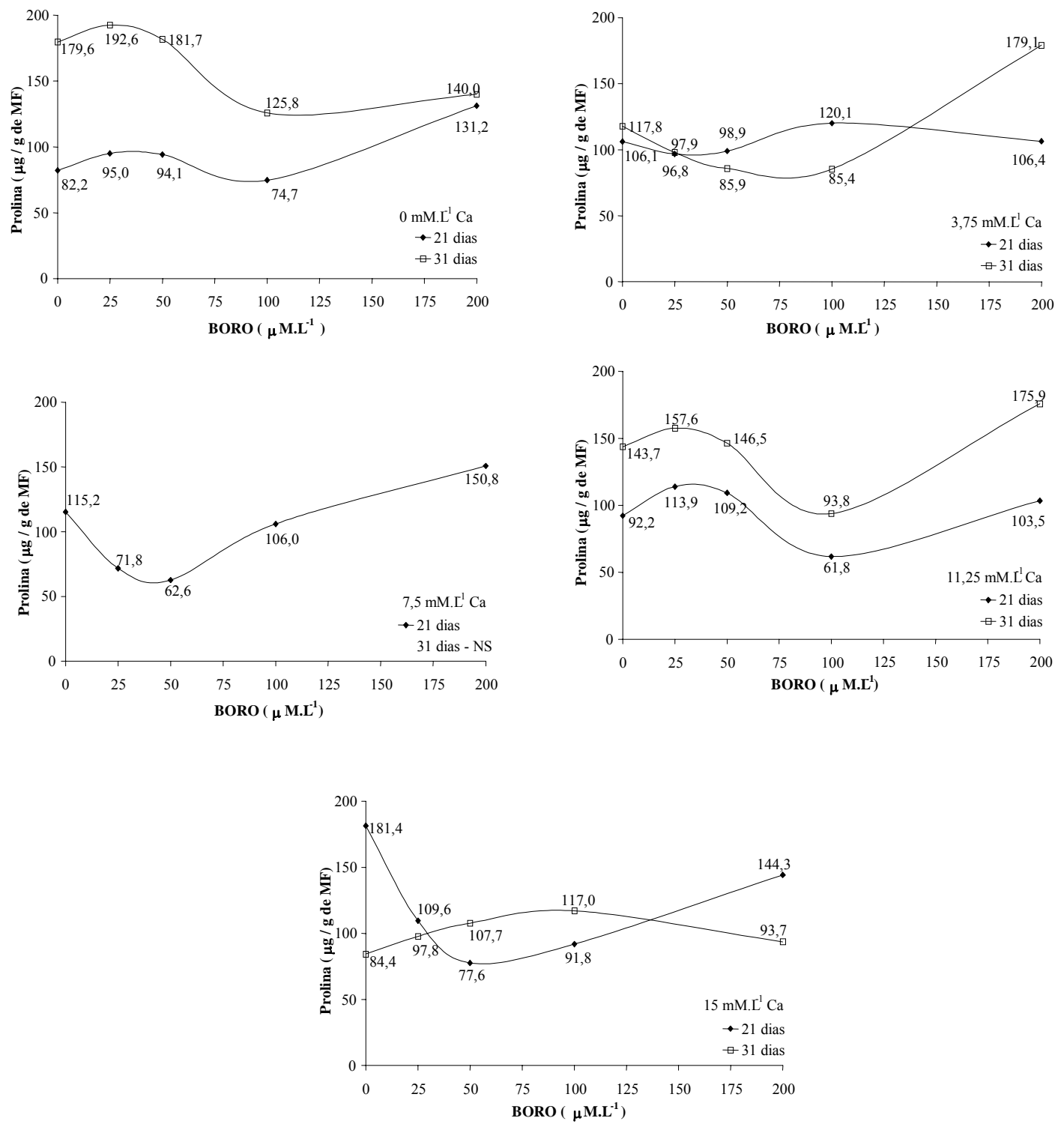

Figura 221 - Teor de prolina ( $\mu \mathrm{g}$ / g massa fresca) de calos E. urophylla avaliada aos 21 e 31 dias de cultivo in vitro em função de diferentes concentrações de boro em determinadas concentrações de cálcio no meio de cultura 


\subsubsection{Avaliação dos teores de prolina em função das concentrações de cálcio com diferentes concentrações de boro aos 21 e 31 dias de cultivo in vitro}

As Tabelas 17 e 18 apresentam os modelos de regressão ajustados para a variação da concentração de cálcio dentro de boro, respectivamente aos 21 e 31 dias para a variável prolina em calos de E urophylla.

Observando-se as equações de regressão referentes à variável prolina avaliada aos 21 dias de cultivo in vitro em função das concentrações de cálcio com diferentes concentraçõess de boro (Tabela 17), verificou-se que os modelos que melhores se ajustaram as diferentes concentrações de boro foram os de regressão cúbica, sendo todos significativos a $1 \%$ pelo teste $\mathrm{F}$ da análise da variância da regressão. Somente para as concentrações 25 e $50 \mu \mathrm{M} . \mathrm{L}^{-1}$ de boro, o modelo não se ajustou perfeitamente, pois apresentaram um $\mathrm{R}^{2}$ de 0,54 e 0,62 , respectivamente, apesar de terem sido significativos.

Tabela 17. Equações de regressão correspondentes às concentrações de cálcio $(\mathrm{Ca}), \mathrm{em}$ mM.L ${ }^{-1}$, dentro de cada concentração de boro (B), em $\mu \mathrm{M} . \mathrm{L}^{-1}$, no meio de cultura, para a característica prolina ( $\mu \mathrm{g} / \mathrm{g}$ de Massa Fresca) em calos de E. urophylla avaliada aos 21 dias de cultivo in vitro

\begin{tabular}{lccc}
\hline & \multicolumn{1}{c}{ Equação } & $\mathrm{R}^{2}$ & $\mathrm{P}<\mathrm{F}$ \\
\hline Ca dentro de B 0 & $\hat{\mathrm{Y}}=74,3128+18,9206 \mathrm{x}-3,2541 \mathrm{x}^{2}+0,16474 \mathrm{x}^{3}$ & 0,94 & 0,000 \\
Ca dentro de B 25 & $\hat{\mathrm{Y}}=113,9419+2,6422 \mathrm{x}-1,4539 \mathrm{x}^{2}+0,0823 \mathrm{x}^{3}$ & 0,54 & 0,003 \\
Ca dentro de B 50 & $\hat{\mathrm{Y}}=85,9164-18,0394 \mathrm{x}+3,6634 \mathrm{x}^{2}-0,1631 \mathrm{x}^{3}$ & 0,62 & 0,000 \\
Ca dentro de B 100 & $\hat{\mathrm{Y}}=77,2328+30,2560 \mathrm{x}-5,3702 \mathrm{x}^{2}+0,2260 \mathrm{x}^{3}$ & 0,99 & 0,000 \\
Ca dentro de B 200 & $\hat{\mathrm{Y}}=130,3013-16,1372 \mathrm{x}+2,3748 \mathrm{x}^{2}-0,0925 \mathrm{x}^{3}$ & 0,90 & 0,001 \\
\hline
\end{tabular}

A Tabela 18 apresenta as equações de regressão referentes à variável prolina avaliada aos 31 dias de cultivo em função das concentrações de cálcio com diferentes concentrações de boro. 
Observou-se que os modelos que melhor se ajustaram as diferentes concentrações de boro foram os de regressão cúbica, excetuando-se a concentração $100 \mu \mathrm{M} . \mathrm{L}^{-1}$, que não foi significativa e a concentração $200 \mu \mathrm{M} . \mathrm{L}^{-1}$ de boro, que apresentou ajuste para o modelo de segunda ordem e com um baixo coeficiente de determinação $\left(R^{2}=0,30\right)$.

Todos os modelos ajustados foram significativos a $1 \%$ pelo teste $\mathrm{F}$ da análise da variância da regressão e apresentaram coeficiente de determinação $\left(\mathrm{R}^{2}\right)$ satisfatório, explicando grande parte da variação dos dados.

Tabela 18. Equações de regressão correspondentes às concentrações de cálcio $(\mathrm{Ca})$, em mM. $L^{-1}$, dentro de cada concentração de boro (B), em $\mu \mathrm{M} \cdot \mathrm{L}^{-1}$, no meio de cultura, para a característica prolina ( $\mu \mathrm{g} / \mathrm{g}$ de Massa Fresca) em calos de $E$. urophylla avaliada aos 31 dias de cultivo in vitro

\begin{tabular}{llcc}
\hline & \multicolumn{1}{c}{ Equação } & $\mathrm{R}^{2}$ & $\mathrm{P}<\mathrm{F}$ \\
\hline Ca dentro de B 0 & $\hat{\mathrm{Y}}=195,4420-36,4456 \mathrm{x}+5,4202 \mathrm{x}^{2}-0,2307 \mathrm{x}^{3}$ & 0,99 & 0,000 \\
Ca dentro de B 25 & $\hat{\mathrm{Y}}=141,1373-24,5784 \mathrm{x}+5,5374 \mathrm{x}^{2}-0,2779 \mathrm{x}^{3}$ & 0,87 & 0,000 \\
Ca dentro de B 50 & $\hat{\mathrm{Y}}=215,799-71,9352 \mathrm{x}+11,1428 \mathrm{x}^{2}-0,4537 \mathrm{x}^{3}$ & 0,84 & 0,000 \\
Ca dentro de B 100 & - & - & $\mathrm{ns}$ \\
Ca dentro de B 200 & $\hat{\mathrm{Y}}=141,6321+5,8973 \mathrm{x}-0,5553 \mathrm{x}^{2}$ & 0,30 & 0,014 \\
\hline
\end{tabular}
ns: não significativo pelo teste $\mathrm{F}$

Observou-se um comportamento variado na quantidade de prolina produzida em calos de E urophylla aos 21 dias de cultivo in vitro de acordo com as diferentes concentrações de boro. Portanto, não houve registro de um padrão de comportamento definido para as concentrações do micronutriente testadas em função das concentrações de cálcio (Figura 22).

Quando utilizaram-se as concentrações 25 e $100 \mu \mathrm{M} . \mathrm{L}^{-1}$ de boro, a quantidade de prolina produzida reduziu com o aumento das concentraçõess de cálcio até a 
concentração $11,25 \mathrm{mM} \cdot \mathrm{L}^{-1}$. Em experimentos com plantas de feijão (Phaseolus vulgaris L. cv. Contender) sob o efeito de choque osmótico, Ballester-Fernandez et al. (1997) indicaram que a presença de cálcio favoreceu o aumento de nutrientes essenciais e reduziu sensivelmente a síntese de metabólicos orgânicos.

A maior quantidade de prolina sintetizada foi observada na concentração mais elevada de cálcio $\left(15 \mathrm{mM} . \mathrm{L}^{-1}\right)$ com a ausência de boro. Nas concentrações 50 e $200 \mu \mathrm{M} . \mathrm{L}^{-1}$ de boro o incremento da concentração de cálcio a partir de $11,25 \mathrm{mM} . \mathrm{L}^{-1}$ causou uma redução do teor de prolina nas estruturas calogênicas. A menor quantidade do aminoácido foi encontrada para a combinação de 11,25 mM.L ${ }^{-1}$ de cálcio e $100 \mu$ M.L ${ }^{-}$ ${ }^{1}$ de boro (Figura 22).

Alguns autores relatam a interferência isolada do boro e do cálcio, na síntese de metabólitos orgânicos, no entanto o estudo do efeito da interação destes dois nutrientes sob o em calos de E. urophylla são pouco explorados.

Stefanuto (2002) ao analisar a concentração de prolina em tecidos de E. grandis, verificou que a medida que concentraçõess de cálcio eram implementadas no meio de cultura, os efeitos do estresse decresceram (decréscimo de prolina), sendo que após a retomada dos explantes a condições normais de cultivo, o autor detectou um aumento no níveis de prolina em todos os materiais cultivados, especialmente naqueles com 10 mM. $L^{-1}$ de cálcio.

Shah et al. (1990), ao analisarem a interação do sódio e do cálcio na acumulação de prolina em calos de diferentes cultivares de Medicago sativa, mostraram que o aumento do cálcio resultou em um aumento adicional da concentração de prolina nos calos de uma determinada cultivar.

Simulando os efeitos do estresse salino em Ulva fasciata, Lee \& Liu (1999), constataram que a perda do cálcio celular estava associada ao estresse induzido por $\mathrm{NaCl}$, via acumulação de prolina e inibição da atividade da ProDH (prolina desidrogenase,). 
Desta forma pode-se inferir que a quantidade de prolina produzida aos 21 dias de cultivo foi bastante influenciada pela combinação das concentrações de boro e cálcio. Porém, as maiores produções foram encontradas quando um dos nutrientes estava ausente, juntamente com maiores concentraçõess do outro nutriente (Figura 22).

Considerando a quantidade de prolina produzida aos 31 dias de cultivo (Figura 22), verificou-se um comportamento semelhante para as curvas representativas da quantidade de prolina, exceto na concentração $200 \mu \mathrm{M} . \mathrm{L}^{-1}$ de boro.

A maior quantidade de prolina, foi observada na concentração $50 \mu \mathrm{M} . \mathrm{L}^{-1}$ de boro em combinação com $0 \mathrm{mM} . \mathrm{L}^{-1}$ de cálcio, ao passo que o menor valor foi verificado ao se combinar a concentração $50 \mu \mathrm{M} . \mathrm{L}^{-1}$ de boro com 3,75 mM.L ${ }^{-1}$ de cálcio. De maneira geral, em todas as combinações de boro e a maior concentração de cálcio determinou uma correlação negativa com os teores de prolina.

Observou-se então, que a quantidade de prolina produzida aos 31 dias de cultivo foi bastante influenciada pela combinação das concentrações de cálcio e boro, entretanto a maior concentração de boro resultou numa menor variação da síntese do aminoácido (Figura 22).

Provavelmente o esgotamento natural dos meios de cultura ao longo do período de cultivo, tenha reduzido os níveis de cálcio disponível e de outros nutrientes, e com isso tenha ocorrido uma redução na tolerância por parte dos calos de E. urophylla que passaram a responder à deficiência nutricional acumulando osmólitos como forma de reduzir os feitos do estresse nutricional.

Os acúmulos de prolina são efeitos secundários em resposta ao estresse (Stewart et al., 1966) e desta forma o aumento na concentração de solutos orgânicos em plantas submetidas ao estresse podem desempenhar um papel fundamental no equilíbrio osmótico e na proteção de enzimas em presença de elevadas concentrações de eletrólitos no citoplasma (Greenway \& Munns, 1980).

A tolerância das plantas a altas concentrações de boro não aparece apenas em sua totalidade, existe uma atuação ao nível de órgãos e células, desta forma pode-se inferir 
que as concentrações de cálcio foram capazes de estabilizar processos que levariam ao estresse nutricional, fato que refletiu diretamente nos conteúdos de prolina dos calos.
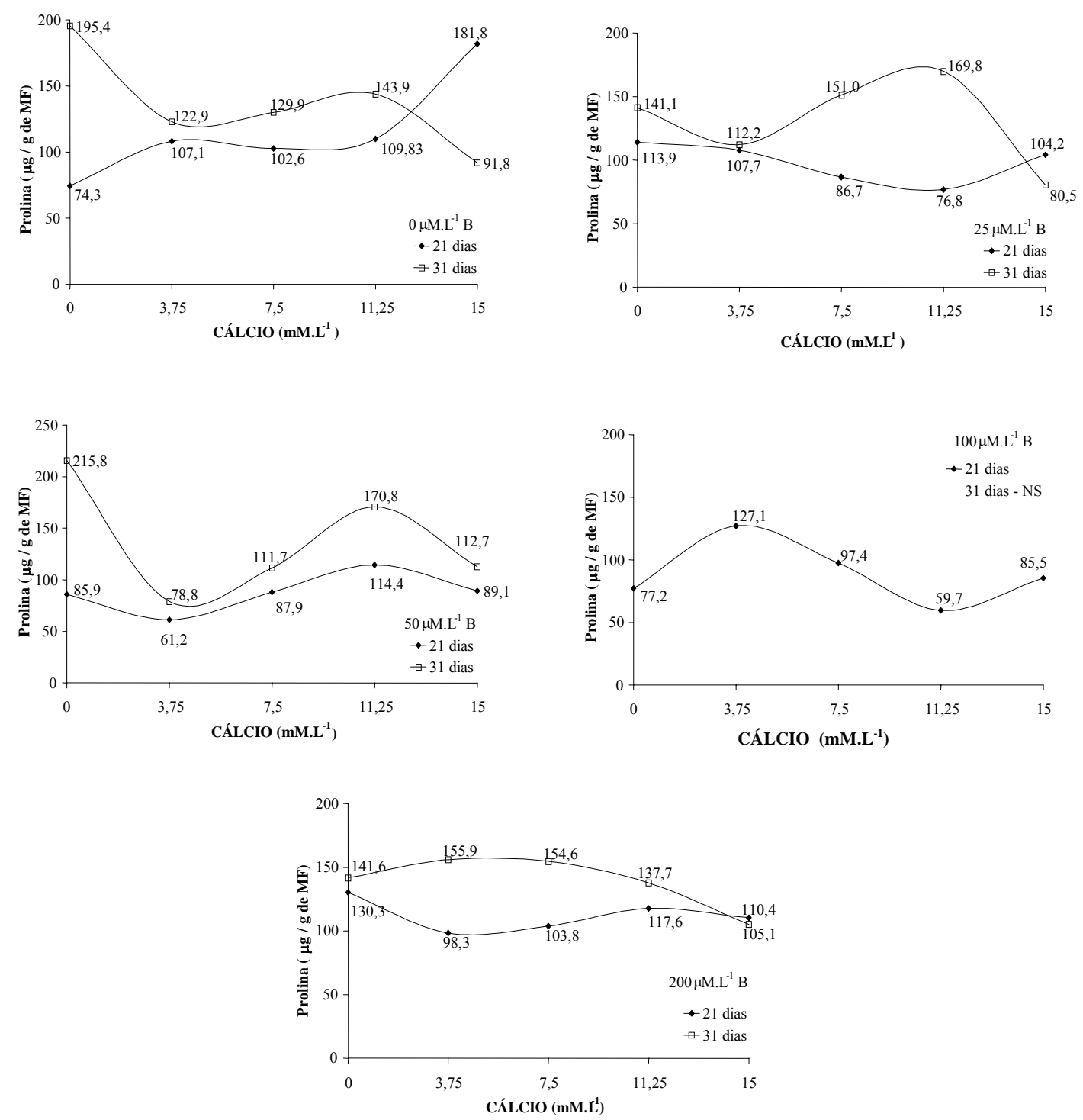

Figura 22 - Teor de prolina ( $\mu \mathrm{g}$ / g massa fresca) de calos E. urophylla avaliada aos $21 \mathrm{e}$ 31 dias de cultivo in vitro em função de diferentes concentrações de cálcio em determinadas concentrações de boro no meio de cultura 


\subsubsection{Avaliação de carboidratos não estruturais solúveis totais}

\subsubsection{Avaliação dos conteúdos de carboidratos não estruturais solúveis totais em} função das concentrações de boro com diferentes concentrações de cálcio aos 21 e 31 dias de cultivo in vitro

As Tabelas 19 e 20 apresentam os modelos de regressão ajustados para a variação da concentração de boro dentro de cálcio, respectivamente aos 21 e 31 dias para a variável carboidratos não estruturais solúveis totais.

Observando-se as equações de regressão referentes à variável carboidratos não estruturais solúveis totais, avaliada aos 21 dias de cultivo in vitro, em função das concentraçõess de boro com diferentes concentraçõess de cálcio (Tabela 19), pode-se identificar que os modelos que melhor se ajustaram as diferentes concentrações de boro com diferentes concentrações de cálcio foram os modelos de regressão cúbica. Todas as equações de regressão foram significativas a $1 \%$ pelo teste $\mathrm{F}$ da análise da variância da regressão e apenas na concentração $3,75 \mathrm{mM} \cdot \mathrm{L}^{-1}$ de cálcio, o modelo mostrou um $\mathrm{R}^{2}$ inferior a 0,50 .

Tabela 19. Equações de regressão correspondentes às concentrações de boro (B), em $\mu \mathrm{M} . \mathrm{L}^{-1}$, dentro de cada concentração de cálcio $(\mathrm{Ca})$, em mM.L ${ }^{-1}$, no meio de cultura, para a característica carboidratos não estruturais solúveis totais (mg/g de Massa Fresca) em calos de E. urophylla avaliada aos 21 dias de cultivo in vitro

\begin{tabular}{lccc}
\hline & \multicolumn{1}{c}{ Equação } & $\mathrm{R}^{2}$ & $\mathrm{P}<\mathrm{F}$ \\
\hline B dentro de Ca 0 & $\hat{\mathrm{Y}}=12,1019-0,1106 \mathrm{x}+0,0010 \mathrm{x}^{2}-0,3 \mathrm{E}-5 \mathrm{x}^{3}$ & 0,99 & 0,000 \\
B dentro de Ca 3,75 & $\hat{\mathrm{Y}}=11,09696-0,0901 \mathrm{x}+0,0011 \mathrm{x}^{2}-0,4 \mathrm{E}-5 \mathrm{x}^{3}$ & 0,41 & 0,000 \\
B dentro de Ca 7,50 & $\hat{\mathrm{Y}}=11,8039-0,0979 \mathrm{x}+0,0013 \mathrm{x}^{2}-0,4 \mathrm{E}-5 \mathrm{x}^{3}$ & 0,98 & 0,000 \\
B dentro de Ca 11,25 & $\hat{\mathrm{Y}}=7,9369+0,1166 \mathrm{x}-0,0017 \mathrm{x}^{2}+0,6 \mathrm{E}-5 \mathrm{x}^{3}$ & 0,75 & 0,000 \\
B dentro de Ca 15 & $\hat{\mathrm{Y}}=9,0293+0,0231 \mathrm{x}-0,0016 \mathrm{x}^{2}+0,7 \mathrm{E}-5 \mathrm{x}^{3}$ & 0,72 & 0,000 \\
\hline
\end{tabular}


Observando-se as equações referentes à variável carboidrato não estruturais solúveis totais, avaliada aos 31 dias de cultivo in vitro, em função das concentrações de boro com diferentes concentrações de cálcio (Tabela 20), identificou-se que os modelos que melhor se ajustaram as diferentes concentrações de cálcio foram os modelos de regressão cúbica, exceto para a concentração com 7,5 mM.L ${ }^{-1}$ de cálcio, cujo modelo foi quadrático. Todas as equações de regressão foram significativas a $1 \%$ pelo teste $\mathrm{F}$ da análise da variância da regressão, sendo que os modelos apresentaram coeficientes de determinação satisfatórios.

Tabela 20. Equações de regressão correspondentes às concentrações de boro (B), em $\mu \mathrm{M} . \mathrm{L}^{-1}$, dentro de cada concentração de cálcio $(\mathrm{Ca}), \mathrm{em} \mathrm{mM} \cdot \mathrm{L}^{-1}$, no meio de cultura, para a característica carboidratos não estruturais solúveis totais (mg/g de Massa Fresca) em calos de E urophylla avaliada aos 31 dias de cultivo in vitro

\begin{tabular}{llcc}
\hline & \multicolumn{1}{c}{ Equação } & $\mathrm{R}^{2}$ & $\mathrm{P}<\mathrm{F}$ \\
\hline B dentro de Ca 0 & $\hat{\mathrm{Y}}=5,7371+0,1536 \mathrm{x}-0,0020 \mathrm{x}^{2}+0,6 \mathrm{E}-5 \mathrm{x}^{3}$ & 0,30 & 0,000 \\
B dentro de Ca 3,75 & $\hat{\mathrm{Y}}=2,8795+0,0196 \mathrm{x}+0,0005 \mathrm{x}^{2}-0,2 \mathrm{E}-5 \mathrm{x}^{3}$ & 0,67 & 0,000 \\
B dentro de Ca 7,50 & $\hat{\mathrm{Y}}=4,0127+0,0620 \mathrm{x}-0,0003 \mathrm{x}^{2}$ & 0,93 & 0,000 \\
B dentro de Ca 11,25 & $\hat{\mathrm{Y}}=9,8410-0,1754 \mathrm{x}+0,0014 \mathrm{x}^{2}-0,3 \mathrm{E}-5 \mathrm{x}^{3}$ & 0,65 & 0,000 \\
B dentro de Ca 15 & $\hat{\mathrm{Y}}=2,1773+0,2941 \mathrm{x}-0,0029 \mathrm{x}^{2}+0,8 \mathrm{E}-5 \mathrm{x}^{3}$ & 0,87 & 0,000 \\
\hline
\end{tabular}

De acordo com a Figura 23, aos 21 dias de cultivo in vitro, a quantidade de carboidratos não estruturais solúveis totais foi influenciada pela disponibilidade do boro e do cálcio e pela interação entre esses dois nutrientes. Observou-se uma menor síntese de carboidratos ao se utilizar a concentração $100 \mu \mathrm{M} \cdot \mathrm{L}^{-1}$ de boro combinada com 15 mM.L $L^{-1}$ de cálcio. Por outro lado, a combinação 7,5 mM.L ${ }^{-1}$ de cálcio com $200 \mu \mathrm{M} . \mathrm{L}^{-1}$ de boro ocasionou a máxima produção de carboidratos, avaliada aos 21 dias de cultivo in vitro, em função das concentraçõess de boro com diferentes concentraçõess de cálcio. 
Aos 31 dias de cultivo, observou-se um comportamento variado para as curvas representativas da quantidade de carboidratos em calos de E urophylla produzida de acordo com as diferentes concentrações de boro (Figura 23).

A maior quantidade de carboidratos foi observada na concentração $3,75 \mathrm{mM} . \mathrm{L}^{-1}$ de cálcio em combinação com a concentração mais elevada de boro, enquanto o menor valor para carboidratos foi verificado ao se omitir o boro com $15 \mathrm{mM} \cdot \mathrm{L}^{-1}$ de cálcio.

A energia suprida pelos carboidratos é usada para a formação futura de raízes e também de brotações. Quando culturas de Pinus radiata diferenciadas para a formação de gemas foram comparadas com culturas não diferenciadas, ficou estabelecido que o acúmulo de alguns precursores (glucose e acetato) foram preferencialmente incorporado em tecidos diferenciados, demonstrando que houve intensificação do metabolismo, associando o metabolismo à diferenciação (Thompson et al.,1987).

Estes dados corroboram com as informações presentes na morfologia interna de calos, onde pode-se verificar uma grande intensificação de processos de diferenciação (rizogênese), em estruturas calogênicas cultivadas sob estas concentrações (Figura 6), ao passo que a omissão do micro e do micronutriente determinaram desestruturações celulares (Figura 11).

Alguns autores citam que carboidratos e prolina são dois dos mais importantes solutos orgânicos acumulados em plantas superiores sob condições de estresse. Sendo a prolina um reconhecido indicador de estresse e carboidratos os precursores necessários como fonte de C e H para a síntese do aminoácido (Stewart, 1978; Laher et al., 1993). Entretanto, de acordo com os dados obtidos não foi encontrada relação entre a máxima produção de prolina, que ocorreu utilizando-se a concentração 0 de boro e 15 de cálcio, e a máxima produção de carboidratos. Ao se comparar as curvas representativas do teor de prolina (Figura 21) e quantidade de carboidratos (Figura 23) com 21 dias, notou-se que as mesmas apresentam uma tendência de variação semelhante de acordo com a variação das concentrações de boro dentro de cálcio. 

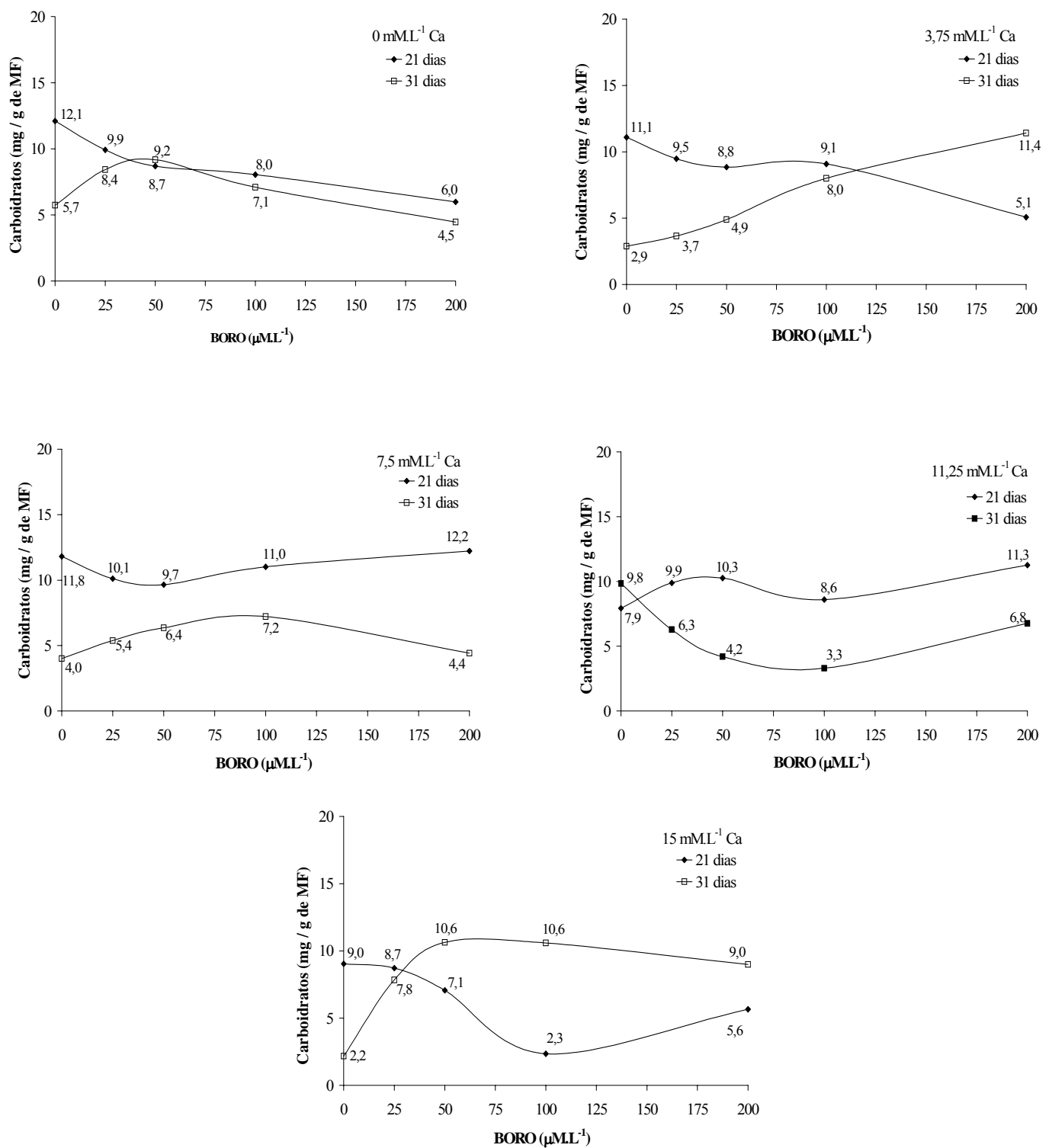

Figura 22 - Quantidade de carboidratos não estruturais solúveis totais (mg / g massa fresca) em calos E. urophylla avaliada aos 21 e 31 dias de cultivo in vitro em função de diferentes concentrações de boro em determinadas concentrações de cálcio no meio de cultura 
Ao comparar as curvas representativas do teor de prolina (Figura 21) e a quantidade de carboidratos (Figura 23) produzida aos 31 dias de cultivo in vitro, em função das concentraçõess de boro, notou-se que estas não mostraram uma tendência de variação semelhante, ao contrário dos dados obtidos para 21 dias. No maior período de cultivo, os calos apresentaram uma série de fatores que interferiram em seu desenvolvimento e conseqüentemente no teor de carboidratos. Isso pode ser verificado inclusive nos baixos valores do coeficiente de determinação para as concentraçõess 0 , 3,25 e 11,25 mM.L $\mathrm{L}^{-1}$ de cálcio.

\subsubsection{Avaliação dos conteúdos de carboidratos não estruturais solúveis totais em função das concentrações de cálcio com diferentes concentrações de boro aos 21 e 31 dias de cultivo in vitro}

As Tabelas 21 e 22 apresentam os modelos de regressão ajustados para a variação da concentração de cálcio dentro de boro, respectivamente aos 21 e 31 dias para a variável carboidratos não estruturais solúveis totais em calos de E urophylla.

Observando-se as equações de regressão referentes à variável carboidratos não estruturais solúveis totais avaliada aos 21 dias de cultivo em função das concentrações de cálcio com diferentes concentrações de boro (Tabela 21), nota-se que as concentrações 25 e $100 \mu \mathrm{M} . \mathrm{L}^{-1}$ de boro apresentaram modelos de regressão quadrática. Já as concentrações 0,50 e $200 \mu \mathrm{M} . \mathrm{L}^{-1}$ de boro mostraram um melhor ajuste dos dados ao se empregar um modelo cúbico. Todas as análises foram significativas a $1 \%$ pelo teste $\mathrm{F}$ da análise da variância da regressão. 
Tabela 21. Equações de regressão correspondentes às concentrações de cálcio $(\mathrm{Ca})$, em mM.L ${ }^{-1}$, dentro de cada concentração de boro (B), em $\mu \mathrm{M} \cdot \mathrm{L}^{-1}$, no meio de cultura, para a característica carboidratos não estruturais solúveis totais em calos (mg/g de Massa Fresca) em calos de E urophylla avaliada aos 21 dias de cultivo in vitro

\begin{tabular}{llcr}
\hline & \multicolumn{1}{c}{ Equação } & $\mathrm{R}^{2}$ & $\mathrm{P}<\mathrm{F}$ \\
\hline Ca dentro de B 0 & $\hat{\mathrm{Y}}=11,7503+0,1594 \mathrm{x}-0,0724 \mathrm{x}^{2}+0,0034 \mathrm{x}^{3}$ & 0,52 & 0,005 \\
Ca dentro de B 25 & $\hat{\mathrm{Y}}=10,1455+0,2985 \mathrm{x}-0,0363 \mathrm{x}^{2}$ & 0,97 & 0,000 \\
Ca dentro de B 50 & $\hat{\mathrm{Y}}=8,7169-0,8861 \mathrm{x}+0,2105 \mathrm{x}^{2}-0,0099 \mathrm{x}^{3}$ & 0,98 & 0,000 \\
Ca dentro de B 100 & $\hat{\mathrm{Y}}=8,3378+1,0825 \mathrm{x}-0,0984 \mathrm{x}^{2}$ & 0,98 & 0,000 \\
Ca dentro de B 200 & $\hat{\mathrm{Y}}=10,0787-0,4142 \mathrm{x}+0,1109 \mathrm{x}^{2}-0,0062 \mathrm{x}^{3}$ & 0,52 & 0,000 \\
\hline
\end{tabular}

Para a variável carboidratos não estruturais solúveis totais em calos avaliada aos 31 dias de cultivo in vitro em função das concentrações de cálcio com diferentes concentrações de boro (Tabela 22), observou-se que os modelos que melhor se ajustaram aos dados foram os modelos cúbicos. Todas as análises foram significativas a $1 \%$ pelo teste $\mathrm{F}$ da análise da variância da regressão (Tabela 22).

Tabela 22. Equações de regressão correspondentes às concentrações de cálcio $(\mathrm{Ca})$, em mM.L $L^{-1}$, dentro de cada concentração de boro (B), em $\mu \mathrm{M} \cdot \mathrm{L}^{-1}$, no meio de cultura, para a característica carboidratos não estruturais solúveis totais em calos (mg/g de Massa Fresca) em calos de E urophylla avaliada aos 31 dias de cultivo in vitro

\begin{tabular}{lcrr}
\hline & \multicolumn{1}{c}{ Equação } & $\mathrm{R}^{2}$ & $\mathrm{P}<\mathrm{F}$ \\
\hline Ca dentro de B 0 & $\hat{\mathrm{Y}}=7,0764-3,9579 \mathrm{x}+0,7485 \mathrm{x}^{2}-0,0335 \mathrm{x}^{3}$ & 0,89 & 0,000 \\
Ca dentro de B 25 & $\hat{\mathrm{Y}}=5,2536+0,9093 \mathrm{x}-0,1869 \mathrm{x}^{2}+0,0086 \mathrm{x}^{3}$ & 0,72 & 0,000 \\
Ca dentro de B 50 & $\hat{\mathrm{Y}}=11,2927-3,4488 \mathrm{x}+0,4353 \mathrm{x}^{2}-0,0136 \mathrm{x}^{3}$ & 0,86 & 0,000 \\
Ca dentro de B 100 & $\hat{\mathrm{Y}}=6,2465+1,9666 \mathrm{x}-0,4136 \mathrm{x}^{2}+0,0197 \mathrm{x}^{3}$ & 0,85 & 0,000 \\
Ca dentro de B 200 & $\hat{\mathrm{Y}}=7,0545-0,2796 \mathrm{x}+0,0556 \mathrm{x}^{2}-0,0023 \mathrm{x}^{3}$ & 0,10 & 0,031 \\
\hline
\end{tabular}


Através da Figura 24, pode-se verificar a variação da quantidade de carboidratos não estruturais solúveis totais produzida em calos de $E$ urophylla aos 21 dias de cultivo in vitro foi marcadamente influenciada pela disponibilidade de cálcio combinado com as concentrações de boro. Para as concentraçõess 25 e $100 \mu \mathrm{M} . \mathrm{L}^{-1}$ de boro o acréscimo da concentração de cálcio no meio de cultura induziu um menor conteúdo de carboidratos em calos de E. urophylla.

A redução da quantidade dos carboidratos pode estar associada não somente com a concentração de cálcio, mas também a interferência deste macronutriente sobre outros componentes que constituem o meio de cultura. A maior quantidade de carboidratos foi observada na concentração $0 \mu \mathrm{M} \cdot \mathrm{L}^{-1}$ de boro e $0 \mathrm{mM} \cdot \mathrm{L}^{-1}$ de cálcio, enquanto o menor quantidade foi verificada na concentração de $100 \mu \mathrm{M} \cdot \mathrm{L}^{-1}$ de boro com $15 \mathrm{mM} \cdot \mathrm{L}^{-1}$ de cálcio (Figura 24).

Observou-se um comportamento variado para as curvas representativas da quantidade de carboidratos produzida para o período de cultivo de 31 dias (Figura 24), a menor quantidade de carboidratos foi observada na concentração $3,75 \mathrm{mM} . \mathrm{L}^{-1}$ de cálcio em combinação com $0 \mu \mathrm{M} . \mathrm{L}^{-1}$ de boro, enquanto o maior valor para carboidratos foi encontrado ao se utilizar $50 \mu \mathrm{M} . \mathrm{L}^{-1}$ de boro com $15 \mathrm{mM} . \mathrm{L}^{-1}$ de cálcio.

Da mesma forma que as análises apresentadas para boro em função de cálcio, a comparação das curvas representativas do teor de prolina (Figura 22) e a quantidade de carboidratos (Figura 24) produzida aos 31 dias de cultivo in vitro em função das concentraçõess de cálcio com diferentes concentraçõess de boro, não apresentaram um padrão de variação semelhante para o teor de prolina e quantidade de carboidratos.

Nas análises para boro dentro de cálcio no período de cultivo mais longo, os calos apresentaram uma série de fatores que interferiram em seu desenvolvimento e conseqüentemente no teor de carboidratos. Isso pode ser verificado inclusive nos baixos valores do coeficiente de determinação para a concentração $200 \mu \mathrm{M} \cdot \mathrm{L}^{-1}$ de boro.

Considerando as afirmações de Thompson et al. (1987) de que os carboidratos são usados como fontes para a formação de futuras raízes e brotações, e os dados da morfologia interna podemos afirmar que as interações de boro e cálcio foram responsáveis pelo incremento dos conteúdos de carboidratos e também promoveram a diferenciação dos calos da mesma forma que na analise anterior (boro dentro de cálcio). 

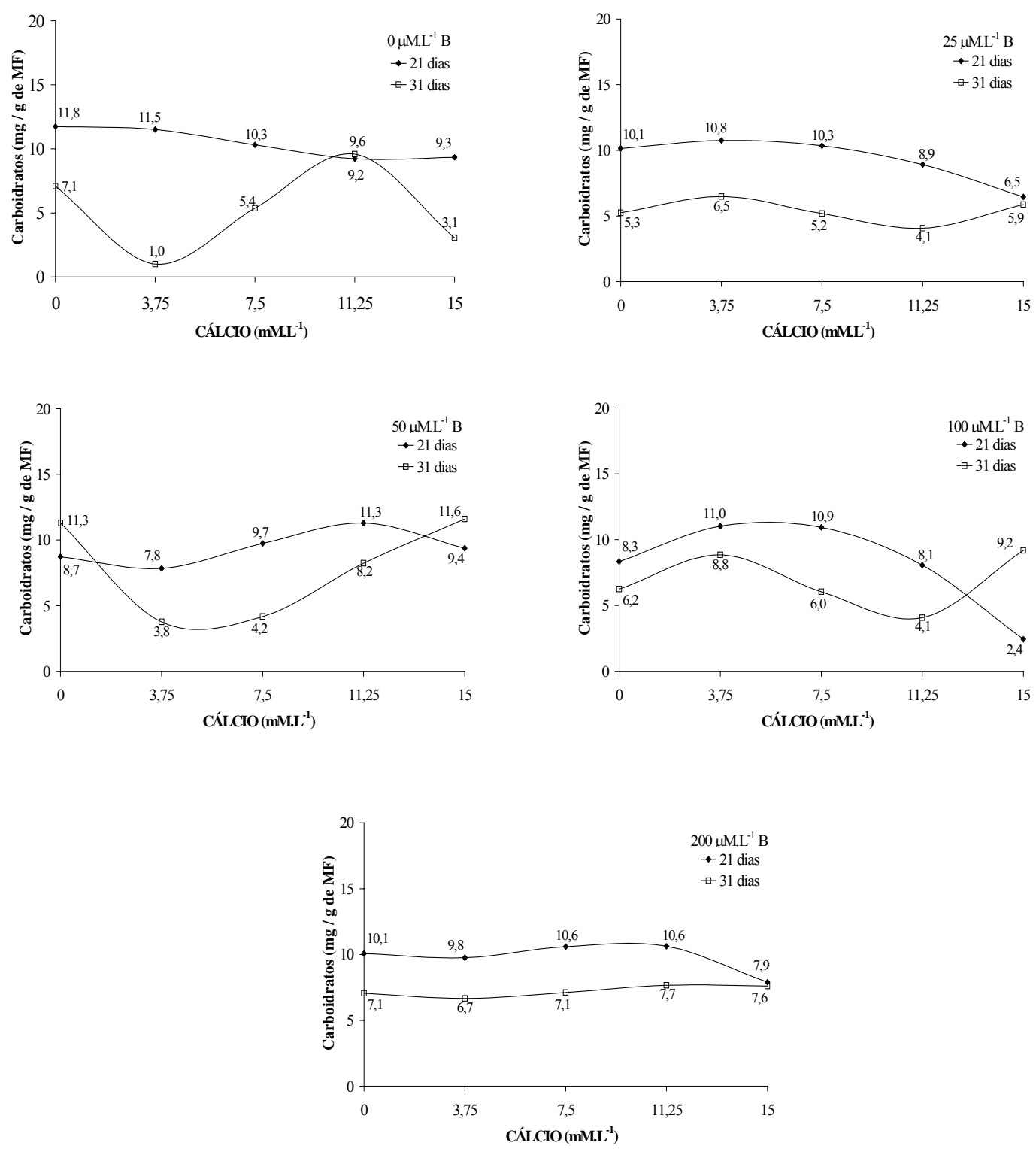

Figura 23 - Quantidade de carboidratos não estruturais solúveis totais (mg / g massa fresca) em calos E. urophylla avaliada aos 21 e 31 dias de cultivo in vitro em função de diferentes concentrações de cálcio em determinadas concentrações de boro no meio de cultura 


\subsubsection{Avaliação do conteúdo de proteínas solúveis totais}

\subsubsection{Avaliação dos conteúdos de proteínas solúveis totais em função das concentrações de boro com diferentes concentrações de cálcio aos 21 dias de cultivo in vitro}

A Tabela 23 apresenta os modelos de regressão ajustados para a variação da concentração de boro dentro de cálcio, aos 21 dias de cultivo in vitro, para a variável proteína. Aos 31 dias, a variação da concentração de boro dentro de cálcio não foi significativa para conteúdo de proteína em calos de E. urophylla cultivados in vitro (Tabela 6). Observou-se que os modelos que melhor se ajustaram as diferentes concentrações de cálcio foram os modelos de regressão cúbica, exceto o modelo referente a concentração $11,5 \mathrm{mM} . \mathrm{L}^{-1}$ de cálcio que é quadrático. Todas as equações de regressão foram significativas a $1 \%$ pelo teste $\mathrm{F}$ da análise da variância da regressão.

Apesar de terem sido significativos para as concentrações 3,25 e 11,5 mM.L ${ }^{-1}$ de cálcio, os modelos não se ajustaram perfeitamente, uma vez que apresentaram $\mathrm{R}^{2}$ inferior a 0,50 .

Tabela 23. Equações de regressão correspondentes às concentrações de boro (B), em $\mu \mathrm{M} . \mathrm{L}^{-1}$, dentro de cada concentração de cálcio $(\mathrm{Ca}), \mathrm{em} \mathrm{mM.L^{-1 }}$, no meio de cultura, para a característica proteínas (mg / g de Massa Fresca) em calos de E. urophylla avaliada aos 21 dias de cultivo in vitro

\begin{tabular}{llcc}
\hline & \multicolumn{1}{c}{ Equação } & $\mathrm{R}^{2}$ & $\mathrm{P}<\mathrm{F}$ \\
\hline B dentro de Ca 0 & $\hat{\mathrm{Y}}=9,1923+0,1368 \mathrm{x}-0,0013 \mathrm{x}^{2}+0,4 \mathrm{E}-5 \mathrm{x}^{3}$ & 0,89 & 0,000 \\
B dentro de Ca 3,75 & $\hat{\mathrm{Y}}=11,2069+0,0868 \mathrm{x}-0,0009 \mathrm{x}^{2}+0,3 \mathrm{E}-5 \mathrm{x}^{3}$ & 0,49 & 0,003 \\
B dentro de Ca 7,50 & $\hat{\mathrm{Y}}=11,7645+0,0967 \mathrm{x}-0,0011 \mathrm{x}^{2}+0,4 \mathrm{E}-5 \mathrm{x}^{3}$ & 0,90 & 0,000 \\
B dentro de Ca 11,25 & $\hat{\mathrm{Y}}=11,6052+0,0387 \mathrm{x}-0,0002 \mathrm{x}^{2}$ & 0,47 & 0,000 \\
B dentro de Ca 15 & $\hat{\mathrm{Y}}=11,8181+0,1273 \mathrm{x}-0,0016 \mathrm{x}^{2}+0,5 \mathrm{E}-5 \mathrm{x}^{3}$ & 0,89 & 0,000 \\
\hline
\end{tabular}

De acordo com a Figura 25, aos 21 dias de cultivo in vitro, observou-se um acréscimo do teor de proteínas solúveis totais de acordo com o aumento da concentração 
de boro, no entanto estas oscilações não foram grandes. Apenas nas concentrações de 0 , 3,75 e 7,5 e 15 mM.L ${ }^{-1}$ de cálcio estas variações foram mais perceptíveis. Nestas concentrações do macronutriente foram encontradas as maiores quantidades de proteínas para a concentração $200 \mu \mathrm{M} . \mathrm{L}^{-1}$ de boro. Assim, verificou-se que concentraçõess mais elevadas de boro foram capazes de produzir uma maior quantidade de proteína, sendo o maior conteúdo de proteína verificado na combinação de $3,75 \mathrm{mM} . \mathrm{L}^{-1}$ de cálcio e $200 \mu \mathrm{M} . \mathrm{L}^{-1}$ de boro.

Trevizam (2001) ao analisar calos de E. urophylla em cultivo in vitro verificou a interferência isolada do boro na quantificação de proteínas solúveis totais e mostrou que diante das concentraçõess avaliadas $50 \mu \mathrm{M} \cdot \mathrm{L}^{-1}$ de boro foi o que apresentou a maior produção de proteínas.

Winner et al. (2003) afirmam que sob concentraçõess tóxicas de boro o conteúdo total de proteínas solúveis totais de folhas de trigo sofreram aumentos, e concluíram que a combinação de estresse hídrico e nutricional foram responsáveis por mudanças quantitativas e qualitativas na produção de proteínas. Estas dados podem ser verificados também através da analise dos géis de poliacrilamida, aos 21 e 31 dias (Figuras 27 e 28) onde foram determinadas mudanças significativas em proteínas de pesos moleculares entre 66,2 e $24,4 \mathrm{kDa}$.

Notou-se também que a ausência de boro do meio de cultura causou menor produção de proteínas solúveis totais em calos de E. urophylla em todas as concentrações de cálcio empregadas, e a ausência total destes dois nutrientes no meio de cultura (Figura 25) resultou no menor no teor de proteína para 21 dias de cultivo in vitro. Estes dados também foram observados por Trevizam (2001) que constatou que a ausência do boro foi determinante para a menor produção de proteínas solúveis totais em calos de E. urophylla cultivados com concentraçõess crescentes de boro.

Borsani et al. (1999) afirmam que sob condições de estresse os conteúdos de proteínas não sofrem modificações. No entanto, Souza et al. (1999) e Stefanuto (2002) ao analisarem os conteúdos de proteínas em Eucalyptus determinaram a interferência de concentrações minerais na produção destes metabó́litos.
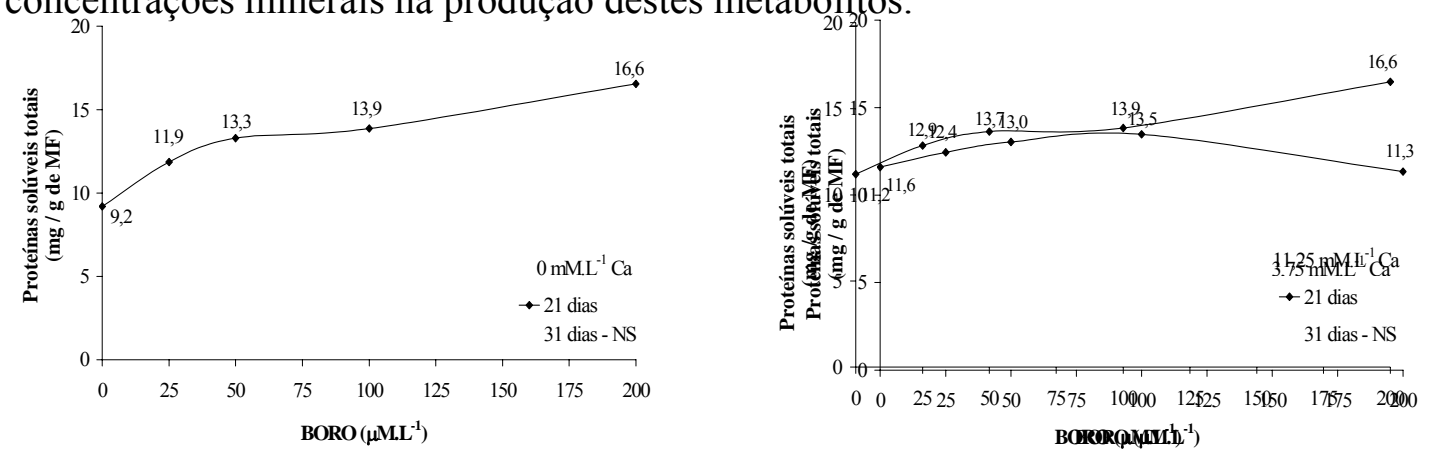

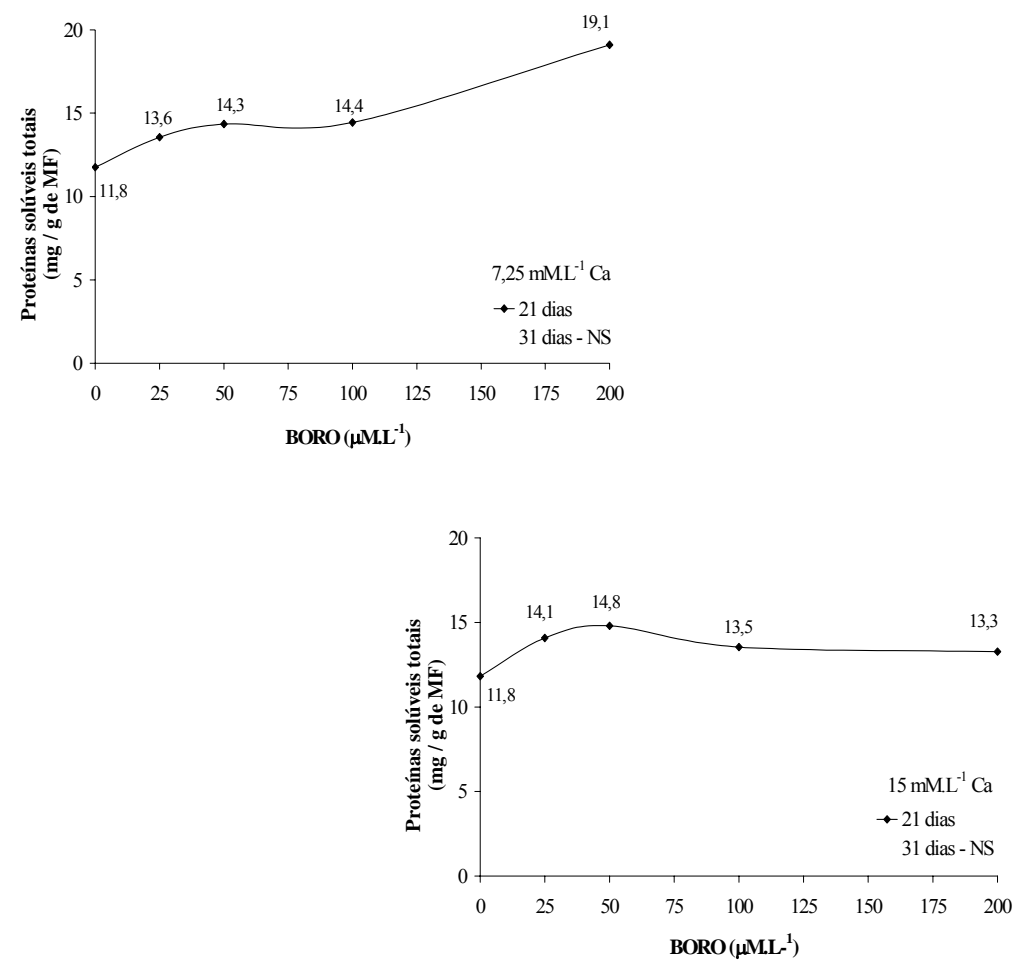

Equações não significativas não foram representadas

Figura 24 - Conteúdo de proteínas solúveis totais (mg / g massa fresca) em calos E. urophylla avaliada aos 21 dias de cultivo in vitro em função de diferentes concentrações de boro em determinadas concentrações de cálcio no meio de cultura

\subsubsection{Avaliação dos conteúdos de proteínas solúveis totais em função das concentrações de cálcio com diferentes concentrações de boro aos 21 dias de cultivo in vitro}

A Tabela 24 apresenta os modelos de regressão ajustados para a variação da concentração de cálcio dentro de boro, aos 21 dias de cultivo in vitro, para a variável proteína. Aos 31 dias, a variação da concentração de cálcio dentro de boro não foi significativa para conteúdo de proteína em calos de E. urophylla cultivados in vitro (Tabela 6). 
As concentrações 100 e $200 \mu \mathrm{M} \cdot \mathrm{L}^{-1}$ de boro não apresentaram modelos significativos, ao passo que as concentrações 0 e $50 \mu \mathrm{M} \cdot \mathrm{L}^{-1}$ de boro apresentaram modelos de regressão quadrática e $25 \mu \mathrm{M} \cdot \mathrm{L}^{-1}$ de boro mostrou um melhor ajuste dos dados ao se empregar um modelo cúbico. Todos os modelos foram significativos pelo teste $\mathrm{F}$ da análise da variância da regressão e apresentaram $\mathrm{R}^{2}$, superiores a 0,90 (Tabela 24).

Tabela 24. Equações de regressão correspondentes às concentrações de de cálcio $(\mathrm{Ca})$, em mM.L ${ }^{-1}$, dentro de cada concentração de boro (B), em $\mu M \cdot L^{-1}$, no meio de cultura, para a característica proteínas ( $\mathrm{mg} / \mathrm{g}$ de Massa Fresca) em calos de E. urophylla avaliada aos 21 dias de cultivo in vitro

\begin{tabular}{lccc}
\hline & Equação & $\mathrm{R}^{2}$ & $\mathrm{P}<\mathrm{F}$ \\
\hline Ca dentro de B 0 & $\hat{\mathrm{Y}}=9,5439+0,4270 \mathrm{x}-0,0198 \mathrm{x}^{2}$ & 0,92 & 0,001 \\
Ca dentro de B 25 & $\hat{\mathrm{Y}}=11,1294+1,3613 \mathrm{x}-0,1977 \mathrm{x}^{2}+0,0082 \mathrm{x}^{3}$ & 0,91 & 0,000 \\
Ca dentro de B 50 & $\hat{\mathrm{Y}}=13,7171-0,2025 \mathrm{x}+0,0138 \mathrm{x}^{2}$ & 0,90 & 0,015 \\
Ca dentro de B 100 & - & - & $\mathrm{ns}$ \\
Ca dentro de B 200 & - & - & $\mathrm{ns}$ \\
\hline
\end{tabular}

ns: não significativo pelo teste $\mathrm{F}$

Observou-se um comportamento regular para as curvas representativas da quantidade proteínas solúveis totais produzida aos 21 dias de cultivo in vitro, de acordo com a variação da concentração de cálcio dentro das concentrações de boro (Figura 26).

A maior quantidade de proteínas solúveis totais foi observada na concentração $25 \mu \mathrm{M} . \mathrm{L}^{-1}$ de boro em combinação com a concentração mais elevada de cálcio (15 $\mathrm{mM} . \mathrm{L}^{-1}$ ), enquanto o menor conteúdo foi verificado ao se omitir conjuntamente o boro e o cálcio. Arruda et al. (2000) analisaram a interferência do cálcio em quantificações de proteínas totais e verificaram que concentraçõess crescentes do macronutriente determinaram o aumento nas concentrações de proteínas em calos de E. urophylla 
cultivados in vitro. Já, Trevizam (2001) verificou que o incremento das concentrações de boro não foi capaz de determinar uma relação direta na produção de proteínas.

De acordo com as avaliações verificou-se que a quantidade de proteínas solúveis totais produzida aos 21 dias de cultivo não foi muito influenciada pela combinação das concentrações de boro e cálcio (Figura 26). Considerando-se que a síntese de proteínas é a função central de todas as células e na sua ausência o crescimento e a manutenção dos órgãos cessam e isso representa um fator limitante à taxa de crescimento das plantas. Ao se comparar estas informações com os dados da morfologia externa de calos (Figura 1) e com a produção de massa fresca e seca (Figura 17 e 19) podemos observar que um crescimento inferior destas estruturas quando comparadas com outras interações nutricionais.

Embora, os dados para 31 dias não tenham sido significativos, a relação inversa na produção da proteínas, no tamanho, no conteudo de massa fresca e massa seca dos calos também foi verificado, indicando uma interferencia de combinações detreminadas de boro e cálcio neste período.
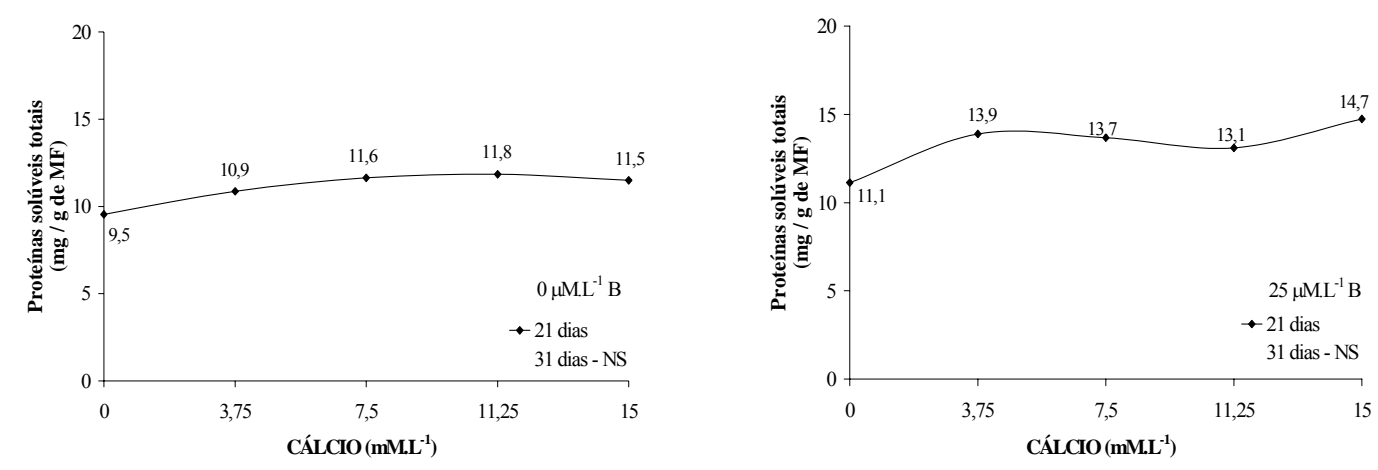


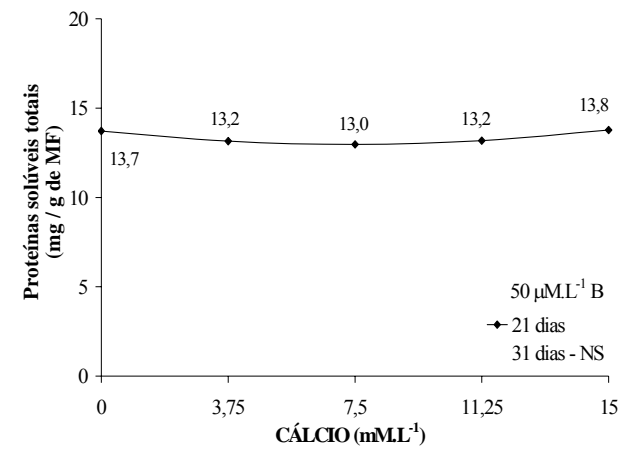

Equações não significativas não foram representadas

Figura 25 - Conteúdo de proteínas solúveis totais (mg / g massa fresca) em calos E urophylla avaliada aos 21 dias de cultivo in vitro em função de diferentes concentrações de cálcio em determinadas concentrações de boro no meio de cultura

\subsection{Eletroforese de proteínas solúveis totais em gel de poliacrilamida (SDS- PAGE)}

Os métodos de eletroforese são amplamente utilizados na pesquisa com proteínas, quando se pretende determinar por exemplo, a pureza das amostras avaliadas ou a massa molecular das proteínas presentes nas amostras (Coopeland, 1994). A Figura 27 apresenta o gel de poliacrilamida com a expressão de bandas de proteínas solúveis totais aos 21 dias de cultivo in vitro e a Figura 28 apresenta o gel com os 26 tratamentos analisados em calos aos 31 dias de cultivo in vitro, com pesos moleculares variando de 18,4 a $90,0 \mathrm{kDa}$. 
De maneira geral, ao longo da corrida do gel notou-se que a distribuição das bandas protéicas procedeu-se de forma semelhante para os dois períodos de cultivo. Diante da leitura dos dois géis (Figura 27 e Figura 28) notou-se uma ocorrência mais clara para bandas entre 24,4 e $66,2 \mathrm{kDa}$, sendo que as proteínas com pesos inferiores a 24,4 kDa não apresentaram uma separação muito evidente, enquanto em pesos superiores a $66,2 \mathrm{kDa}$ as bandas protéicas evidenciadas não mostraram grande destaque.

Diversos autores apontam a faixa de peso molecular compreendido entre $18 \mathrm{e}$ $45 \mathrm{kDa}$ como essenciais para a contínua expressão e manutenção de embriogênese somática (Pechan et al., 1991; Kiyosue et al., 1991).

Arruda (2004) observou diferenças no número e na intensidade de bandas protéicas em diferentes fases de desenvolvimento de embriões somáticos. De acordo com o autor, na fase globular os embriões expressam proteínas compreendidas na faixa entre 25 e $45 \mathrm{kDa}$.

Corroborando com estes dados, o presente estudo também evidenciou através de cortes histológicos, a presença de pré-embriões globulares e meristemóides em calos de E. urophylla cultivados in vitro.

Embora os dois períodos de cultivo tenham apresentado algumas semelhanças observou-se uma menor intensidade de coloração das bandas no gel para as análises realizadas aos 31 dias de cultivo in vitro (Figura 28). Este resultado pode estar relacionado com as quantificações de proteínas solúveis totais, que durante este período não apresentaram significância estatística. O provável esgotamento mineral e energético do meio de cultura também pode ter interferido na síntese de proteínas e consequentemente ter exercido influência na expressão das bandas.

As análises isoladas dos períodos também evidenciaram, para todos os tratamentos, padrões semelhantes de bandas, porém foi possível diagnosticar algumas diferenças na intensidade de expressão das proteínas.

A Figura 27, evidenciou nas combinações $25 \mu \mathrm{M} \cdot \mathrm{L}^{-1}$ de boro com $15 \mathrm{mM} \cdot \mathrm{L}^{-1}$ de cálcio, $50 \mu \mathrm{M} . \mathrm{L}^{-1}$ de boro com 7,5 mM.L ${ }^{-1}$ de cálcio e $100 \mu \mathrm{M} . \mathrm{L}^{-1}$ de boro com 11,25 mM.L $\mathrm{L}^{-1}$ de cálcio uma intensidade de expressão mais intensa para todas as bandas 
em relação as que se apresentaram nas outras interações. Contrariamente, as combinações $0 \mu \mathrm{M} . \mathrm{L}^{-1}$ de boro com 0 e $3,75 \mathrm{mM} . \mathrm{L}^{-1}$ de cálcio registraram a menor intensidade de coloração para todas as bandas protéicas visualizadas através do gel.

Este fato pode ser associado a quantidade de proteínas solúveis totais, uma vez que a combinação $25 \mu \mathrm{M} . \mathrm{L}^{-1}$ de boro com $15 \mathrm{mM} \cdot \mathrm{L}^{-1}$ de cálcio foi responsável por uma das maiores quantidades de proteínas solúveis totais verificada.

Ainda aos 21 dias de cultivo in vitro pode-se constatar a expressão de quatro bandas protéicas maiores que $24,4 \mathrm{kDa}$ e menores que $66,2 \mathrm{kDa}$ que não apareceram no padrão (P) (Figura 27: linhas pontilhadas I, II, III e IV). No entanto, de acordo com a variação das concentrações de boro e cálcio, as bandas apresentaram diferenças na intensidade de coloração.

A análise de proteínas por SDS-PAGE aos 31 dias, da mesma forma que aos 21 dias de cultivo, registrou a presença de 3 bandas protéicas localizadas entre 45,5 e 66,2 kDa (Figura 28, linhas I, II e III). No entanto, as bandas de menores pesos moleculares que apareciam no período anterior de análise (21 dias) próximas a 24,4 $\mathrm{kDa}$, foram suprimidas aos 31 dias, exceto para o meio N7.

Estes dados podem ser relacionados com os estudos de Arruda (2004), que ao monitorar parâmetros minerais, fisiológicos e bioquímicos em discos foliares de maracujá cultivados in vitro sob diferentes temperaturas, determinou padrões específicos de bandas em processos de organogenêse adventícia. De acordo com o autor, houve nas análises em SDS-PAGE a presença de uma banda protéica entre 18,4 e 25,5 kDa relacionada com a interferência da temperatura e com processos organogênicos sob interferência do cálcio e demais nutrientes. Assim poderíamos inferir que a presença do cálcio e do boro, no período mais curto de cultivo determinou a expressão de uma proteína com peso molecular superior, porém muito próximo de $24,4 \mathrm{kDa}$, que provavelmente estaria envolvida na manifestação de respostas morfogenéticas, incluindo a rizogênese que se apresentou na maioria dos tratamentos durante os 21 dias de cultivo in vitro. 
Aos 31 dias de cultivo, o meio N7 foi o que apresentou maior destaque na expressão das bandas, enquanto que a omissão conjunta de boro e cálcio, mostrou uma menor intensidade de coloração para todas as bandas expressas. Comparando este último resultado com o gel do período anterior (Figura 27) verificou-se que aos 21 dias de cultivo, a ausência do macro e micronutriente também foi responsável pela menor intensidade de coloração. Assim neste estudo podemos supor que as omissões conjuntas de boro e cálcio foram capazes de determinarem diferenças importantes na expressão de bandas protéicas em calos cultivados in vitro.

$\mathrm{Na}$ Figura 28, podemos verificar através das 3 linhas representadas no gel (I, II e III) a ausência de bandas protéicas encontradas em interações específicas de boro e cálcio, ou seja na linha I: combinações $0 \mu \mathrm{M} . \mathrm{L}^{-1}$ de boro com 0 e $15 \mathrm{mM} . \mathrm{L}^{-1}$ de cálcio, $25 \mu \mathrm{M} . \mathrm{L}^{-1}$ de boro com 11,25 mM.L ${ }^{-1}$ de cálcio, $200 \mu \mathrm{M} . \mathrm{L}^{-1}$ de boro com 3,75 mM.L ${ }^{-1}$ de cálcio; linha II: $0 \mu \mathrm{M} . \mathrm{L}^{-1}$ de boro com $0 \mathrm{mM} . \mathrm{L}^{-1}$ de cálcio e $200 \mu \mathrm{M} . \mathrm{L}^{-1}$ de boro com 3,75 mM.L $\mathrm{L}^{-1}$ de cálcio e na linha III: $0 \mu \mathrm{M} . \mathrm{L}^{-1}$ de boro com 0 e $15 \mathrm{mM} . \mathrm{L}^{-1}$ de cálcio e 25 $\mu \mathrm{M} . \mathrm{L}^{-1}$ de boro com $3,75,11,25$ mM.L ${ }^{-1}$ de cálcio.

Como a quantificação de proteínas para este período não foi significativa estatisticamente podemos supor que, períodos prolongados de cultivo também interferem na expressão de bandas protéicas como conseqüência do déficit na absorção ou redistribuição dos minerais dentro dos tecidos vegetais causando assim, prejuízos para as atividades metabólicas essenciais. 


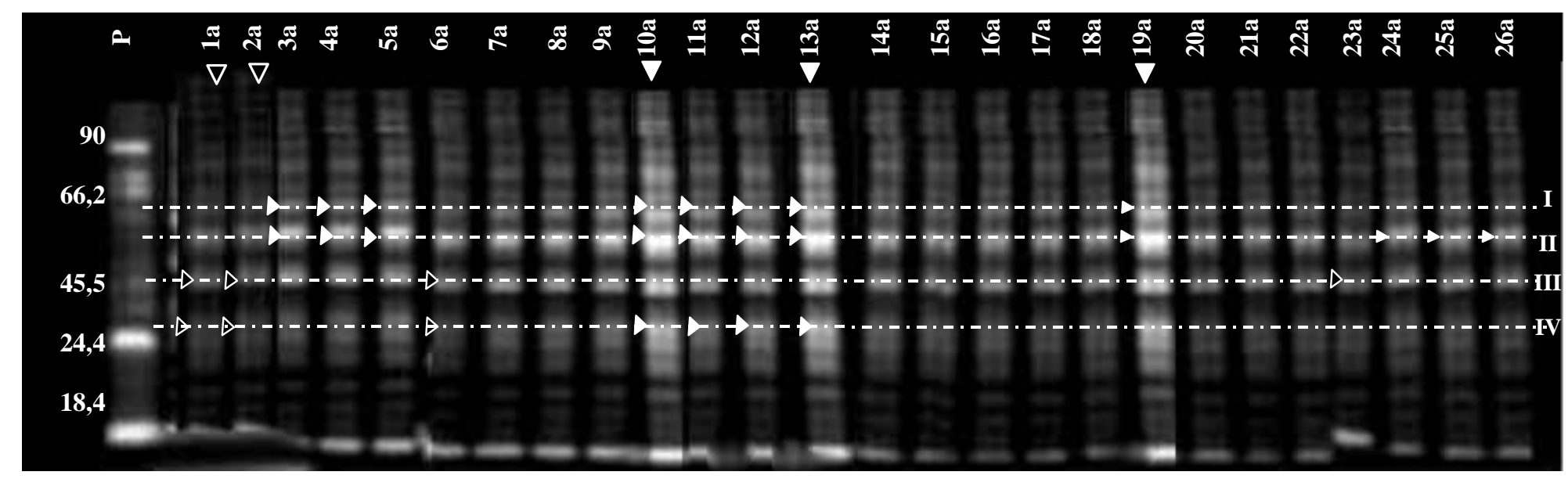

Figura 26 - Gel SDS-PAGE de proteínas solúveis totais de E. urophylla cultivados in vitro, por 21 dias, submetidos a diferentes combinações de boro e cálcio. Os números acompanhados de letras representam os tratamentos definidos, na Tabela 2. As setas indicam diferenças no grau de coloração: PRETAS, indica menor intensidade de coloração; BRANCAS, indica maior intensidade de coloração. As linhas pontilhadas determinam a presença de bandas que não apareceram no padrão $(\mathrm{P})$ 


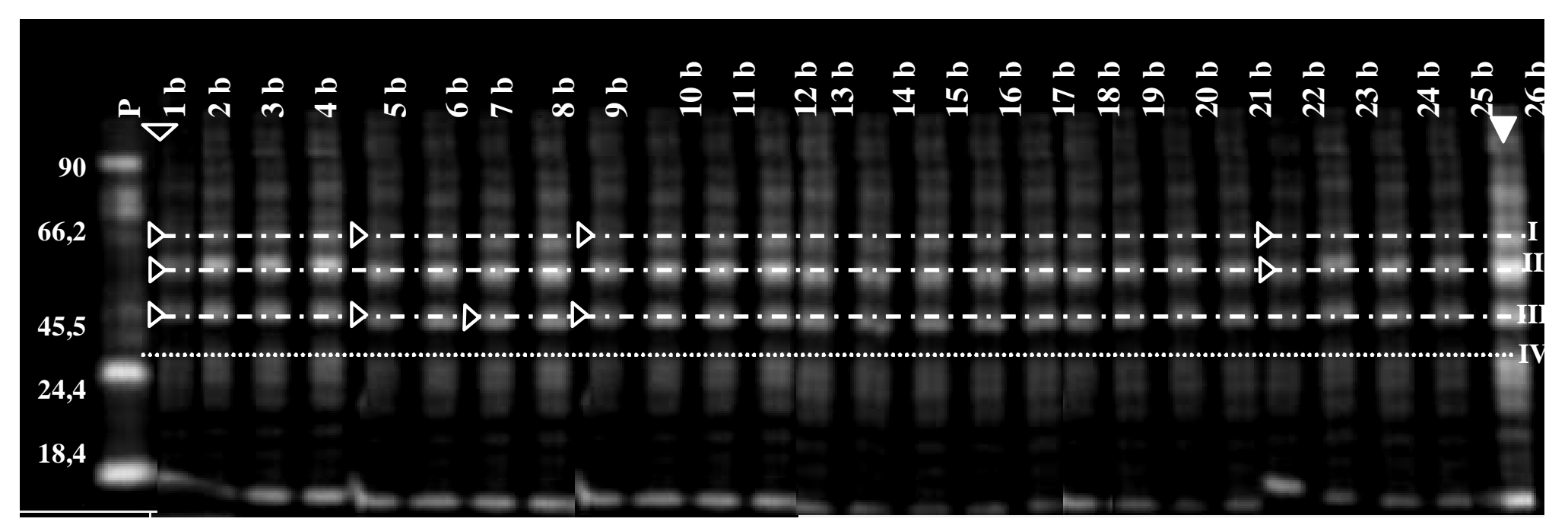

Figura 27 - Gel SDS-PAGE de proteínas solúveis totais de E. urophylla cultivados in vitro, por 31 dias, submetidos a diferentes combinações de boro e cálcio (Tabela 2). As setas indicam diferenças no grau de coloração. PRETAS: indica menor intensidade de coloração; BRANCA: indica maior intensidade de coloração. As linhas pontilhadas (I, II e III) determinam a presença de bandas que não apareceram no padrão (P). A linha pontilhada IV indica a presença de uma banda expressa aos 21 dias de cultivo in vitro e ausente na maioria dos tratamentos aos 31 dias de cultivo in vitro 


\section{CONCLUSÕES}

A análise dos calos aos 21 e 31 dias, mostrou que a interação nutricional entre o boro e o cálcio foi capaz de determinar diferenças importantes quanto aos aspectos da morfologia externa, morfologia interna e parâmetros bioquímicos em calos de E. urophylla. Com base nestes resultados pode-se verificar a importância desta interação nutricional para processos morfogenéticos e metabólicos em calos de E. urophylla cultivados in vitro.

Estas afirmações se basearam nas seguintes considerações:

- $\quad$ A interação boro e cálcio determinou mudanças especificas na morfologia externa dos calos, aos 21 e 31 dias de cultivo;

- Os maiores tamanhos dos calos foram visualizados na concentração $50 \mu \mathrm{M} . \mathrm{L}^{-1}$ de boro e 7,5 mM.L $\mathrm{L}^{-1}$ de cálcio (21 dias) e no meio N7 (31 dias). Já a concentração $0 \mu \mathrm{M} . \mathrm{L}^{-1}$ de boro e $0 \mu \mathrm{mM} \cdot \mathrm{L}^{-1}$ de cálcio determinaram os menores tamanhos nos dois períodos analisados;

- A avaliação da morfologia interna em concentrações combinadas de boro e cálcio, determinou a presença de meristemóides aos 21 e 31 dias, no entanto estas estruturas diferiram quando as conformações celulares;

- Desenvolvimento precoce de xilema foram verificados aos 31 dias nas combinações $100 \mu \mathrm{M} . \mathrm{L}^{-1}$ de boro com 11,25 e 15,0 mM.L ${ }^{-1}$ de cálcio e $200 \mu \mathrm{M} . \mathrm{L}^{-1}$ de boro com 11,25 e 15,0 mM.L $\mathrm{L}^{-1}$ de cálcio;

- Raízes foram verificadas aos 21 e 31 dias, no entanto combinações específicas caracterizaram uma maior fragilidade ou coesão com a massa de calos; 
- Raízes não apresentaram diferenciação completa do cilindro vascular, aos 21 dias, nas combinações $0 \mu \mathrm{M} . \mathrm{L}^{-1}$ de boro com 3,75, 7,5, 11,25 e 15 mM.L ${ }^{-1}$ de cálcio, $50 \mu \mathrm{M} . \mathrm{L}^{-1}$ de boro com 0 mM.L ${ }^{-1}$ de cálcio, $100 \mu \mathrm{M} . \mathrm{L}^{-}$ ${ }^{1}$ de boro com $0 \mathrm{mM} . \mathrm{L}^{-1}$ de cálcio e $200 \mu \mathrm{M} . \mathrm{L}^{-1}$ de boro com $0 \mathrm{mM} . \mathrm{L}^{-1}$ de cálcio. Tais aspectos também foram verificados para o período de cultivo de 31 dias nas combinações $0 \mu \mathrm{M} . \mathrm{L}^{-1}$ de boro com $15 \mathrm{mM} . \mathrm{L}^{-1}$ de cálcio e $50 \mu \mathrm{M} . \mathrm{L}^{-1}$ de boro com $0 \mathrm{mM} . \mathrm{L}^{-1}$ de cálcio;

- $\quad$ As combinações $25 \mu \mathrm{M} . \mathrm{L}^{-1}$ de boro com $0,3,75,7,5,11,25$ e $15 \mathrm{mM} . \mathrm{L}^{-1}$ de cálcio, aos 21 dias, mostraram-se menos destrutivas às raízes, denotando uma formação mais habitual do órgão

- Raízes não foram verificadas ao se omitir o boro e o cálcio conjuntamente;

- Aspectos gelatinosos foram verificados em calos de E. urophylla cultivados no período de 21 dias, nas combinações $0 \mu \mathrm{M} . \mathrm{L}^{-1}$ de boro com $0,3,75,7,5$ e 11,25 mM.L ${ }^{-1}$ de cálcio e $200 \mu \mathrm{M} . \mathrm{L}^{-1}$ de boro com 0 mM.L' 1 de cálcio, que também não mostraram processos de diferenciação celular;

- Estruturas globulares foram verificadas na maioria dos tratamentos, aos 31 dias e mostraram processos de diferenciação celular característicos; Aos 21 dias, estruturas globulares foram determinadas nas combinações $25 \mu \mathrm{M} . \mathrm{L}^{-1}$ de boro com 7,5, 11,25 e $15 \mathrm{mM} . \mathrm{L}^{-1}$ de cálcio, $50 \mu \mathrm{M} . \mathrm{L}^{-1}$ de boro com 7,5, 11,25 mM.L'

- Friabilidade foi um aspecto comum aos dois períodos de cultivo, e analises da morfologia interna mostraram poucos processos de diferenciação celular;

- Oxidações dos calos foram comuns em todos os tratamento avaliados aos 31 dias, com destaque para a combinação $200 \mu \mathrm{M} \cdot \mathrm{L}^{-1}$ de boro com 15 mM.L $\mathrm{L}^{-1}$ de cálcio; 
- As áreas oxidadas aos 21 dias, analisadas através da morfologia interna mostraram diferenciação quanto a distribuição dos compostos fenólicos em relação aos calos mantidos em cultivo por 31 dias;

- $\quad$ Antocianinas foram mais visualizadas na combinação $50 \mu \mathrm{M} . \mathrm{L}^{-1}$ de boro com 7,5 mM.L-1 de cálcio, aos 21 dias.

- $\quad$ Estruturas pré-globulares foram evidenciadas, aos 21 dias, na combinação $50 \mu \mathrm{M} . \mathrm{L}^{-1}$ de boro com 7,5 mM.L ${ }^{-1}$ de cálcio;

- A massa fresca dos calos sofreram interferência das interações nutricionais nos dois períodos de avaliação;

- A massa seca dos calos foi influenciada pela interação boro e cálcio, aos 21 e 31 dias;

- Avaliação dos teores de prolina sofreram os efeitos das interações nutricionais aos 21 e 31 dias de cultivo in vitro;

- $\quad$ Avaliação de carboidratos não estruturais solúveis totais, mostram uma interferência das combinações do macro e micronutriente nos períodos testados;

- Avaliação do conteúdo de proteínas solúveis totais sofreram a interferência das combinações nutricionais testadas apenas aos 21 dias de cultivo;

- A analise do gel de poliacrilamida, mostrou diferenças de coloração e expressão e bandas dentro do período analisado e também ao se comparar os dois tempos de analise. 


\section{REFERÊNCIAS BIBLIOGRÁFICAS}

ABDEL-BASSET, R. Calcium channels and membrane disorders induced by drought stress in Vicia faba plants supplemented with calcium. Acta Physiologiae Plantarum, v.20, n.2, p.149-153, 1998. /Resumo CAB Abstracts, 1998/08 $1999 / 07 /$.

AITKEN, R.L.; McCALLUM, L.E. Boron toxicity in soil solution. Australian Journal of Soil Resource, v.26, p.605-610, 1988.

AKERMAN, K.E.O.; NICHOLLS, D.G. Physiological and bioenergetic aspects of mitochondrial calcium transport. Reviews of Physiology, Biochemistry and Pharmacology, v.18, p. 149-201, 1983.

ALBERTS, B.; BRAY, D; LEWIS, J. et al. Biologia molecular da célula. 3.ed. Porto Alegre: Artes Médicas, 1997. 1294p.

ALFENAS, A.C; PETERS, I.; BRUNE, W. et al. Eletroforese de proteínas e isoenzimas de fungos e essências florestais. Viçosa : SIF, 1991. 241p.

ALMEIDA, M. Emprego da cultura in vitro" para a multiplicação vegetativa de pupunha (Bactris gasipaes H.B.K.) Palmae. São Paulo, 1994. 100p. Tese (Doutorado) Instituto de Biociências, Universidade de São Paulo.

AMMIRATO, P.V. Embryogenesis. In: EVANS, D.A.; SHARP, W.R.; AMMIRATO, P.V. et al. (Ed.). Handbook of plant cell culture. New York: Mac Millan, 1983. p.82-123. 
ARLAND JUNIOR, T.H.; EL-BAHTIMY, K.; FISHMAN, M.L. Analysis of pectin structure by HPAE-PAD. In: LINSKENS, H.F.; JACKSON, J.F. (Ed.) Plant cell wall analysis. Berlin: Springer-Verlag , 1996. p. 129 - 146. (Modern Methods of Plant Analysis, 17).

ARRUDA, S.C.C. Efeito do cálcio na indução de embriogênese somática de Eucalyptus urophylla. Piracicaba, 2000. 74 p. Dissertação (Mestrado) - Escola Superior de Agricultura "Luiz de Queiroz", Universidade de São Paulo.

ARRUDA, S.C.C. Caracterização da morfogênese in vitro através de parâmetros fisiológicos e bioquímicos. Piracicaba, 2004. 156 p. Tese (Doutorado) - Centro de Energia Nuclear na Agricultura, Universidade de São Paulo.

ARRUDA, S.C.C.; SOUZA, G.M.; ALMEIDA, M. et al. Anatomical and biochemical characterization of the calcium effect on Eucalyptus urophylla callus morphogenesis in vitro. Plant Cell, Organ and Tissue Culture, v. 63, n.2, p.142-154, 2001.

BALLESTER-FERNANDEZ, G.; CERDÁ, G.; MARTÍNEZ, V. Role of calcium shortterm responses of bean plants to osmotic or saline shocks. Journal of Plant Physiology, v.151, p.741-747, 1997.

BANUELO, G.; CARDON, M.; BEM-ASHER, J. et al. Boron and selenium removal in boron laden soil by four sprinkler irrigated plant species. Journal of Environmental Quality, v.22, p.786-792, 1993.

BARROS, N.F.; NOVAIS, R.F.; NEVES, J.C.L. Fertilização e correção do solo para plantio de eucalipto. In: BARROS, N.F.; NOVAIS, R.F. (Ed.). Relação soloeucalipto. Viçosa: Ed. Folha de Viçosa, 1990. p. 127-186.

BARROS, N.F.; NOVAIS, R.F.; NEVES, J.C.L. et al. Fertilizing eucalypt plantations on the brazilian savannah soils. South African Forestry Journal, v.160, p. 7-12, 1992.

BATES, L. S.; WALDREN, R. P.; TEARE, I. D. Rapid determination of free proline for water-stress studies. Plant and Soil, v. 39, p. 205-207, 1973. 
BELL, A.D. Plant form: on illustrated guide to flowering plant morphology. Oxford: Oxford University Press, 1991. 231p.

BELL, R.W.; McLAY, L.; PLASKETT D. et al. International boron requirements of green gram (Vigna radiata). In: VAN BEUSICHEM, M.L. (Ed.). Plant nutritionphysiology and application. Amsterdan: Kluwer Academic Press, 1990. p.275-280.

BELLINGER, Y.; BENSAOUD, A.; LARHER, F. Physiological significance of proline accumulation, a trait of use to breeding for stress tolerance. In: ACEVEDO, E.; CONESA, A.P.; SRIVASTAVA, J.P. (Ed.). Physiology: breeding of winter cereals for stressed mediterranean environments. London: INRA, 1991. 449-488.

BEN-HAYYIM, G.; NEUMANN, H. Stimulatory effect of glycerol on growth and somatic embryogenesis in Citrus callus cultures. Zeitschrift Füer Pflanzenphysiologie, v.110, p.331-337, 1983.

BERGMANN, W. Colour atlas: nutritional disorders of plants. New York: Gustav Fisher, 1992. 350p.

BHOJWANI, S.S.; RAZDAM, M.K. Plant tissue culture: theory and practice. Amsterdan: Elsevier, 1996. 767p.

BISKO, A.; COSIC, T.; POLJAK, M. et al. The effect of boron growth and development in strawberry (Fragaria ananassa Duch.) shoot culture. In: INTERNATIONAL SYMPOSIUM ON BORON IN SOIL AND PLANTS, Chiang Mai, 1997. Proceedings. Dordrecht: Kluwer Academic Press, 1997. p.165-169.

BLAMEY, F.P.C. Boron nutritions of sunflowers on an Avalon medium sandy loam. Agrochemophysica, n.8, p.5-10, 1976.

BLAMEY, F.P.C.; EDWARDS, D.G.; ASHER, C.J. Nutritional disorders of sunflowers. St. Lucia: Department of Agriculture, 1987. 72p.

BOLAÑOS, L.; MATEO P.; BONILLA I. Calcium-mediated recovery of boron deficient Anabaena sp. PCC7119 grown under nitrogen fixing conditions. Journal of Plant Physiology, v.142, p.513-517, 1993. 
BONILLA, I.; BOLAÑOS, L.; MATEO, P. Interaction of boron and calcium in the cyanobacteria Anabaena and Synechococcus. Physiologia Plantarum, n. 94. p 31$36,1995$.

BONILLA, I.; VILLASEÑOR, C.M.; CAMPOS, M.A. et al. The aberrant cell walls of boron-deficient bean root nodules have no covalently bound hydroxyproline-proline rich proteins. Plant Physiology, v.115, p. 1329-1340, 1997.

BORGATTO, F.; DIAS, C.T.S.; AMARAL, A.F.C. et al. Tratamento de plantas matrizes de Chrysanthemum morifolium cv. "Bi Time" com $\mathrm{Ca}^{+2}, \mathrm{~K}^{+} \mathrm{E} \mathrm{Mg}^{+2} \mathrm{e}$ calogênese in vitro. Scientia Agricola, v.59, n.4, 689-693, 2002.

BORLE, A.B. Control, modulation and regulation of cell calcium. Reviews of Physiology, Biochemistry and Pharmacology, v.90, p. 130-169, 1981.

BORSANI, O.; DÍAZ, P.; MONZA, J. Proline is involved in water stress responses of Lotus corniculatus nitrogen fixing and nitrate fed plants. Journal of Plant Physiology, v. 155, p.269-273, 1999.

BRADFORD, G.R. Boron. In: CHAPMAN, H.D. (Ed.). Criteria for plants and soils. Riverside: Addison-Wesley, University of California, 1966. p.33-61.

BRADFORD, M.M. A rapid and sensitive method for the quantitation of microgram quantities of protein utilizing the principle of protein-dye binding. Analytical Biochemistry, v.72, p.248-254, 1976.

BRETT, C.; WALDRON, K. Physiology and biochemistry of plant cell walls. 2.ed. Cambridge: Cambridge University Press, 1996. 255p.

BROWN, P.H.; HU, H. Boron uptake by sunflower, squash and culture tobacco cells. Physiologia Plantarum, v.91, p.435-441, 1994.

BROWN, P.H.; HU, H. Phloem mobility of boron is species dependent: evidence for phloem mobility in sorbitol-rich species. Annals of Botany, v.77, p.497-505, 1996. 
BROWN, P.H.; SHELP, B. Boron mobility in plants. Plant and Soil, v.193, p. 58-101, 1997.

BRUM, G.; McKANE, L.; KARP, G. Biology: exploring life. 2.ed. New York: John Wiley, 1994. $1030 \mathrm{p}$.

BUTTON, J. The effect of some carbohydrates on the growth and organization of Citrus ovular callus. Zeitschrift Füer Pflanzenphysiologie, v.88, p.61-68, 1978.

CAKMAK, I.; RÖMHELD, V. Boron impairments of cellular functions in plants. Plant and Soil, v. 193, p. 71-83, 1997.

CAKMAK, I.; KURZ, H.; MARSCHNER, H. Short-term effects of boron germanium and high light intensity on membrane permeability in boron deficient leaves of sunflower. Physiologia Plantarum, v.59, p.11-18, 1995.

CAMARA, T.R.; WILLADINO, L.; TORNE, J.M. et al. Efeito da putrescina e do estresse salino em calos de milho. Revista Brasileira de Fisiologia Vegetal, v.10, p.153-156, 1998.

CANNON, P.G. Fourth results of forest fertilization with NPK, calfos and borax on Andept soil. Research Report Investigation Forestal, v.68, p.10, 1981.

CARPENA, R.O.; ESTEBAN, E.; SARRO, M.J. et al. Boron and calcium distribution in nitrogen-fixing pea plants. Plant Science, v.151, p. 163-170, 2000.

CARTWRIGHT, B.; ZARCINAS, B.A.; MAYFIELD, A.H. Toxic concentrations of boron in red-brown earth at Gladstone, South Australia. Australian Journal of Soil Research, v. 22, p.261-272, 1984.

CARVALHO, C.M.; CORSO, G.M.; VEIGA, R.A.A. et al. Aspectos sintomatológicos, morfológicos e anatômicos da deficiência de B em plantações de Eucalyptus. In: SYMPOSIUM AND WOORKSHOP ON GENETIC, IMPROVEMENT AND PRODUCTIVITY OS FAST GROWING TREE SPECIES, Águas de São Pedro, p.8 (mimeografado), 1980. 
CHAPMAN, K.S.R.; JACKSON, J.F. Increased RNA labelling in boron-deficient root tip segments. Phytochemistry, v.13, p.1311-1318, 1974.

CHRISTIANSON, M.L.; WARNICK, D.A. Organogenesis in vitro as a developmental process. HortScience, v.23, p.515-519, 1988.

COHEN, M.S.; LEPPER, R. Effects of boron on cell elongation and division in squash roots. Plant Physiology, v.59, p.884-887, 1977.

COKE, L.; WHITTINGTON, W.J. The role of boron in plant growth. Iv. Interrelashionships between boron indol-3-yl acetic acid in the metabolism of bean radicles. Journal of Experimental Botany, n.19, p. 295-308, 1968.

CORDOBA-PEDREGOSA, M.D.C.; GONZALES-REYES, J.A.; CANADILLAS, M.D. et al. Role of apoplastic cell wall peroxidases on the stimulation of root elongation by ascorbate. Plant Physiology, v.112, p. 1119-1125, 1996.

COOPELAND, R.A. Methods for protein analysis: a practical guide for laboratory protocols. New York:Chapmann \& Hall, 1994. 228p.

CORREIA, D. Crescimento e desenvolvimento de gemas na multiplicação de Euicalyptus spp. in vitro em meio de cultura liquido e sólido. Piracicaba, 1993. 113p. Dissertação (Mestrado) - Escola Superior de Agricultura "Luiz de Queiroz", Universidade de São Paulo.

CROCOMO, O.J. Biotecnologia de plantas: aplicações da engenharia celular. Biotecnologia: Agropecuária, Energia e Saúde, n.17, p.1-4, 1988.

DARVILL, A.; McNEIL, M.; ALBERSHEIM, P. et al. The primary cell wall of flowering plants. In: TOLBERT, N.E. (Ed.). The biochemistry of plants: a comprehensive treatise. New York: Academic Press, 1980. p. 91-161.

DAS, N.; MISRA, M.; MISRA, A. Sodium chloride salt stress induced metabolic changes in callus cultures of Pear millet: free solute accumulation. Journal of Plant Phisiology, v.137, p.244-246, 1990. 
DE VRIES, J.A.; ROMBOUTS, F.M.; VORAGEN, A.G.J. et al. Enzymatic degradation of apple pectins. Carbohydrate Polymer, v.2, p.25-33, 1982.

DUGGER, W.M. Boron in plant metabolism. In: LAUCHLI, A.; BIELESKI, R.L. (Ed.).. Plant physiology. Berlin: Springer-Verlag, 1983. p.626-650 (Encyclopedia of Plant Physiology, New Series, 15).

ECK, P.; CAMPBELL, F.J. Effect of high calcium application on boron tolerance of carnation, (Dianthus caryophyllus). Journal of the American Society for Horticultural Science, v.81, p. 510-517, 1962.

ELDRIDGE, K.; DAVIDSON, J., HARDOWOOD, C. et al. Eucalypt domestication and breeding. Oxford: Clarendon Press, 1994. 288p.

EPSTEIN, E. Mineral nutrition of plants: principles and perspectives. New York: Wiley, 1982. 344p.

EVANS, J. Plantation forestry in the tropics. Oxford: Clarendon Press, 1993. 403p.

FACKLER, U.; GOLDBACH,H.; WEILER, E.W. et al. Influence of boron deficience on indol-3yl-acetic acid and abscisic acid in the metabolism levels in root and shoot tips. Journal of Plant Physiology, v.119, p.295-299, 1985.

FEIJÓ, J. A.; MALHO, R.; OBERMEYER, G. Ion dynamics and its possible role during in vitro pollen germination and tube growth. Protoplasma, v.187, p.155-167, 1995.

FONSECA, S.; MALUF, J.L.P.; OLIVEIRA, A.C. Adubação com B e Zn de Eucalyptus camaldulensis em solos do cerrado na região de Brasilândia. In: CONGRESSO FLORESTAL BRASILEIRO, 6., Campos do Jordão, 1993. Resumos. São Paulo: Sociedade Brasileira de Silvicultura, 1993. p.69.

FOSKET, D.E. Characteristics of plant cells that are important in development. New York: Academic Press, 1994. 580p.

FOYER, C.H.; LELANDAIS, M.; KUNERT, K.J. Photooxidative stress in plants. Physiologia Plantarum, v.92, p. 696-717, 1994. 
FRANÇOIS, L.E. Effect of excess boron on broccoli, cauliflower, and radish. Journal of the American Society for Horticultural Science, v.111, n.4, p.494-498, 1986.

GALLO, L.A.; CROCOMO, O.J. A cultura de tecidos em fitopatologia. In: BERGAMIN FILHO, A.; KIMATI, H.; AMORIN, L. (Ed.). Manual de fitopatologia: princípios e conceitos. São Paulo: Agronômica Ceres, 1995. v.1, cap. 25, p.494-506.

GARCIA-GONZÁLES, M.; MATEO, P.; BONILLA, I. Effect of boron deficiency on photosynthesis and reductant sources and their relationship with nitrogenase activity in Anabaena PCC 7119. Plant Physiology, v.93, p. 560-565, 1990.

GARCIA-GONZÁLES, M.; MATEO, P.; BONILLA, I. Boron requirement for envelope structure and function in Anabaena PCC 7119 heterocysts. Journal of Experimental Botany, v.42, p. 925-929, 1991.

GIMENES, N.L.; TEIXEIRA, R.R.; CARVALHO, S.L. et al. Adubação com boro na cultura da alface (Lactuca sativa L.) cv. Aurélia Repolhuda. Ecossistema, v.15, p.145-148, 1990.

GOMES, K.K.P.; OLIVEIRA, V.C.; LEDO, A.S. et al. Indução de calo a partir de eixo embrionário de coqueiro (Cocos nucifera L.). Revista Brasileira de Fruticultura, v.26, n.1, p.124-126, 2004.

GONÇALVES, J.L.M. Recomendações de adubação para Eucalyptus, Pinus e espécies típicas da Mata Atlântica. Documentos Florestais, n.15, p.1-23, 1995.

GONÇALVES, J.L.M.; VALERI, S.V. Eucaliptos e pinus. In: FERREIRA, M.E.; CRUZ, M.C.P.; RAIJ, B. van. et al. (Ed.). Micronutrientes e elementos tóxicos na agricultura. Jaboticabal : CNPq; FAPESP; POTAFOS, 2001. p.393-423.

GRATTAPAGLIA, D.; MACHADO, M.A. Micropropagação. In: TORRES, A.C.; CALDAS, L.S. Técnicas e aplicações da cultura de tecidos de plantas. Brasília: EMBRAPA, CNPH, 1990. p.99-169. 
GREENWAY, H.; MUNNS, R. Mechanisms of salt tolerance in non halophytes.. Annual Review of Plant Physiology, v.31, p.149-190, 1980.

GUERRA, M.P.; HANDRO, W. Somatic embryogeneis and plant regeneration in embryo culture of Euterpe edulis Mart. (Palmae). Plant Cell Reports, v.7, p.550$552,1988$.

GUERRA, M.P; TORRES, A.C.; TEIXEIRA, J.B. Embriogênese somática e sementes sintéticas. In: TORRES, A.C.; CALDAS, L.S.; BUSO, J.A. (Ed.) Cultura de tecidos e transformação genética de plantas. Brasília: Embrapa-SPI; EmbrapaCNPH, 1999. v. 2, p.533-568.

GUPTA, E.C. Boron and its role in crop production. Boca Raton: CRC Press, 1993. 250p.

GUPTA, U.C. Boron nutrition of crops. Advance in Agronomy, v.31, p.273-307, 1979.

HAKULINEN, J. Nitrogen-induced reduction in leaf phenolic level is not accompanied by increased rust frequency in a compatible willow (Salix myrsinifolia) Melampsora rust interaction. Physiologia Plantarum, v. 102, p.101-110. 1998.

HALE, M. G.; ORCUTT, D. M. The physiology of plants under stress. NewYork: John Wiley, 1987. 205p.

HANDRO, W.; FLOH, E.I.S. Aspectos básicos do controle da morfogênese in vitro. In: TORRES, A.C.; CALDAS, L.S. (Ed.). Técnicas e aplicações da cultura de tecidos de plantas. Brasília: EMBRAPA, CNPH, 1990. p.204-212.

HASEGAWA, P.M.; BRESSAN, R.D.; HANDA, A.K. Cellular mechanism of salinity tolerance. HortScience, v.21, p.1317-1324, 1986.

HAUSE, B.; VAN VEENENDAAL, W.L.H.; HAUSE, G. et al. Expression of polarity during early development on microspore-dirived and zigotic embryos of Brassica napus L. cv. Topas. Botanica Acta, v.107, p. 407-415, 1994. 
HAYASHI, T. K.; MOREIRA, A.; AMARAL, A. F. C. et al. Tratamento de matrizes de cravo (Dianthus caryophyllus L., Caryophyllaceae) com nitrogênio e calogênese in vitro. Scientia Agricola, v. 59, n.1, p.47-52, 2002.

HAYDON, F.G. Boron toxicity in strawberry. Communications in Soil Science and Plant Analisys, v.11, n.12, p.1085-1091, 1981.

HEPLER, P.K.; WAYNE, R. O. Calcium and plant development. Annual Review of Plant Physiology, v.36, p.397-439, 1985.

HIGASHI, E.N. Diagnose da deficiência de nutrientes minerais em três híbridos de Eucalyptus spp. cultivados in vitro. Piracicaba, 1996. 90p. Dissertação (Mestrado) Escola Superior de Agricultura "Luiz de Queiroz", Universidade de São Paulo.

HIGASHI, E.N.; SILVEIRA, R.LV.A.; GONÇALVES, A.N. Monitoramento nutricional e fertilização de macro, mini e microjardim clonal de Eucalyptus. In: GONÇALVES, J.L.M.; BENEDETTI, V. Nutrição e fertilização florestal. Piracicaba: IPEF, 2000. p. $192-215$.

HIGASHI, K.; KAMADA, H.; HARADA, H. The effects of reduced nitrogenous compounds suggests that synthetase activity is involved in the development of somatic embryos in carrot. Plant Cell, Tissue and Organ Culture, v.45, p.109-114, 1997.

HIRSCH, A.M.; PENGELLY, W. L.; TORREY, J.G. Endogenous IAA levels in borondeficient and control root tips of sunflower. Botanical Gazette, v.143, p. 15-19, 1982.

HO, W.; VASIL, I.K. Somatic embryogenesis in sugarcane (Saccharum officinarum L.) I. The morphology and physiology of callus formation and the ontogeny of somatic embryos. Protoplasma, v.118, p.169-180, 1983.

HU, H.; BROWN, P. H. Localization of boron in cell walls of squash and tobacco and its association with pectin. Plant Physiology, v.105, p.681-689, 1994. 
HU, H.; BROWN, P. H. Absorption of boron by plant roots. Plant and Soil, v.193, p.9 $-58,1997$.

HU, H.; BROWN, P.H.; LABAVITCH, J.M. Species variability in boron requirement is correlated with cell wall pectin. Journal of Experimental Botany, v.47, p.227$232,1996$.

HUANG, C; GRAHAM, R.D. Resistance of wheat genotypes to boron toxicity is expressed et the cellular level. Plant and Soil, v. 126, p. 295-300, 1990.

HUANG, L.; YE, Z.; BELL, R.W. The importance of sampling immature leaves for the diagnosis of boron deficiency in oil seed rape (Brassica napus cv. Eureka). Plant and Soil, v. 183, p.187-198, 1996.

INGESTAD, T.; AGREN, G. I. Plant nutrition and growth: basic principles. Plant and Soil, v. 168/169, p. 15-20, 1995.

ISHII, T.; MATSUNAGA, T. Isolation and characterization of a boron rhamnogalac turonan-II complex from cell walls of sugar beet pulp. Carbohydrate Research, v.284, p.1-9, 1996.

JAIN, S.; NAINAWATEE, H.S.; JAIN, R.K.; CHOWDHURY, J. B. Proline status of genetically stable salt-tolerant Brassica juncea somaclones and their parent cv. Prakash. Plant Cell Reports, v. 9, p.684-687, 1991.

JONES JUNIOR, J.B. Plant tissue analysis for micronutrients. In: MORTVEDT, J.J.; GIORDANO, P.M.; LINDSAY, W.L. (Ed.). Micronutrients in agriculture. Madison: Soil Society of America, 1972. p. 319-345.

JONES JUNIOR, J.B; WOLF, B.; MILLS, H.A. Plant analysis handbook: a practical sampling, preparation, analysis and interpretation guide. Athens: Micro-Macro Publish., 1991. 213 p.

JUMIN, H.B.; NITO, N. Plant regeneration via embryogenesis from protoplasts of six plant species related to Citrus. Plant Cell Reports, v.15, p.332-336, 1996a. 
JUMIN, H.B.; NITO, N. Plant regeneration via somatic embryogenesis from protoplasts of Uganda cherry orange (Citropsis schweinfurthii). Plant Cell Reports, v.15, p.754-757, 1996 b.

KARNOVSKI, M.J. A formaldehyde-glutaraldehyde fixative of high osmolality for use in electron microscopy. Journal of Cell Biology, n. 27, p.137-138, 1965.

KEERATI-KASIKORN, P.; BELL, R.W.; PANYA, P. et al. Comparasion of seed yield and quality of peanut (Arachis hypogaea L.) cultivars in low fertility soils and their response to boron and complete fertilizer. In: BARROW, N.J. (Ed.). Plant nutrition from genectic engeneering to field practice. Dordrecht: Kluwer Academic, 409412, 1993. (Developments in Plant and Soil Science, 54).

KERBAUY, G.B. Competência e determinação celular em cultura de células e tecidos de plantas. In: TORRES, A.C.; CALDAS, L.S.; BUSO, J.A. (Ed.). Cultura de tecidos e transformação genética de plantas. Brasília: Embrapa-SPI; EmbrapaCNPH, 1999. v.2, p.519-532.

KHANG, H.; CHUN, Y.W. Plant regeneration throught organogenesis in poplar. In: KLOPFENSTEIN, N.B.; CHUN, Y.W.; KIM, M.S. et al. (Ed.). Micropropagation, genetic engeneering and molecular biology of Populus. Forte Collins: U.S. Department of Agriculture, 1997. cap. 3, p.13-23.

KIKUCHI, A.; SATOH, S.; NAKAMURA, N. et al. Differences in pectic polyssaccharides between carrot embryogenic and non-embryogenic calli. Plant Cell Reports, v.14, p.279-284, 1995.

KIYOSUE T.; SATOH S.; KAMADA H. et al. Purification and immunohistochemical detection of an embryogenic cell protein in carrot. Plant Physiology, v.95, p.10771083, 1991.

KOBAYASHI, M.; MATOH, T.; AZUMA, J-I. Two-chain of rhamnogalacturonan II are cross-linked by borate-diol ester bonds in higher plant cell walls. Plant Physiology, v.110, p.1017-1020, 1996. 
KOCHBA, J.; SPIEGEL-ROY, P.; NEUMANN, H. et al. Effect of carbohydrates on somatic embryogenesis in subcultured nucellar callus of Citrus cultivars. Zeitschrift Füer Pflanzenphysiologie, v.105, p.359-368, 1982.

KOMATSU, H.K. Estudo da morfogênese em calos de Phyllostachys bambusoides Sieb. \& Zucc. Piracicaba, 1995, 105p. Tese (Doutorado) - Escola Superior de Agricultura Luiz de Queiroz, Universidade de São Paulo.

KOUCHI, H.; KUMAZAWA, K. Anatomical responses of root tips to boron deficiency: I. Effects of boron deficiency on elongation of root tips and their morphological characteristics. Soil Science Plant Nutrition, v.21, p.21-28, 1975.

KRUEGER, R.W.; LOVATT, C.J.; ALBERT, L.S. Metabolic requirement of Cucurbita pepo for boron. Plant Physiology, v.83, p.254-258, 1987.

LANGER, M. Estudos e análises dos efeitos do cálcio sobre o crescimento inicial do híbrido de Eucalyptus urophylla x Eucalyptus grandis in vitro. Piracicaba, 2000. 101p. Dissertação (Mestrado) - Escola Superior de Agricultura "Luiz de Queiroz", Universidade de São Paulo.

LARCHER, W. Ecofisiologia vegetal: a planta sob estresse. São Carlos: RiMa, 2000. 529 p.

LARHER, F.; LEPORT, L.; PETRIVALSKY, M. et al. Effectors for the osmoinduced proline response in higher plants. Plant Physiology and Biochemistry, v.31, p.911992, 1993.

LARKUM, A.W.D. Ionic relations of chloroplast in vivo. Nature, v. 218, p. 447$449,1968$.

LEE, S.; ARONOFF, S. Boron in plants: a biochemical role. Science, v.158, p. 798-799, 1967.

LEE, T.M; LIU, C.H. Regulation of $\mathrm{NaCl}$ - induced proline accumulation by calmodulin via modification of proline dehydrogenase activity in Ulva fasciata (Chlorophyta).

Australian Journal of Plant Physiology, v. 26, p.595-600, 1999. 
LEWIS, D.H. Boron, lignification and origin of vascular plants-a unified hypothesis. New Phytologyst, v. 84, p.209-229, 1980.

LOOMIS, W.D.; DURST, R.W. Chemistry and biology of boron. Biofactors, v.3, p.229-239,1992.

LOVATT, C.J. Evolution of xilem resulted in a requirement for boron in the apical meristems of vascular plants. New Phytologyst, v.99, p.509-522, 1985.

LOVATT, C.J.; BATES, L.M. Early effects of excess boron on photosynthesis and growth of Curcubita pepo. Journal of Experimental Botany, v. 35, p.297-305, 1984.

LUKASZEWSKI, K.M.; BLEVINS, D.G. Root growth inibition in boron-deficient or aluminum-stresse squash plants may be a result of impaired ascorbate metabolism. Plant Physiology, v.112, p.1135-1140, 1996.

LUKASZEWSKI, K.M.; BLEVINS, D.G.; RANDALL, D.D. Asparagine and boric acid cause allantoate accumulation in soybean leaves by inhibiting manganese-dependent allantoate amidohydrolase. Plant Physiology, v.99, p.1670-1676, 1992.

MAGNAVAL, C.; NOIROT, M.; VERDEIL, J.L. et al. Specific nutritional requirements of coconut calli (Cocus nucifera L.) during somatic embryogenesis induction. Journal of Plant Physiology, v.150, p.719-728, 1997.

MALAVOLTA, E. Elementos de nutrição mineral de plantas. São Paulo: Ceres, 1980. 251p.

MALAVOLTA, E. Funções. In: MALAVOLTA, E.; VITTI, G.C.; OLVEIRA, S.A. (Ed.). Avaliação do estado nutricional das plantas: princípios e aplicações. Piracicaba: Potafos, 1997. cap.5, p.55-114.

MALAVOLTA, E.; VITTI, G.C.; OLVEIRA, S.A. Funções princípios, métodos e técnicas de avaliação do estado nutricional. In: MALAVOLTA, E.; VITTI, G.C.; OLIVEIRA, S.A. (Ed.). Avaliação do estado nutricional das plantas: princípios e aplicações. Piracicaba: POTAFOS, 1997. 319p. 
MALHO, R.; TREWAVAS, A. Localized apical increases of cytosolic free calcium control pollen tube orientation. Plant Cell, v.8, p.1935-1949, 1996.

MALHO, R.; MOUTINHO, A.; VAN DER LUIT, A. et al. Spatioal characteristics of calcium signalling: the calcium wave as a basic unit in plant cell calcium signalling. Philosophical Transactions of Royal Society of London, v. 353, p.1463-1473, 1999.

MANYOWA, N.M.; MILLER, T.E. The gentics of tolerance to high mineral concentrations in the tribe Triticale - a rewiew and update. Euphytica, v.57, p. $175-185,1991$.

MARMÉ, D. The role of calcium in the regulation of plant cellular metabolism. In: GERDAY, C.H.; GILLES, R.; BOLIS, L. (Ed.). Calcium and calcium binding proteins. Berlin: Spring-Verlag, 1988. p.201-208.

MARSCHNER, H. Mineral nutrition of higher plants. 2.ed. London: Academic Press, 1995. 889p.

MASCARENHAS, H.A.A. Cálcio, enxofre e ferro no solo e na planta. Campinas: Fundação Cargill, 1977. 95p.

MATOH, T. Boron in plant cell walls. Plant and Soil, v.193, p.59-70, 1997.

MATOH, T.; SAYAKA, K.; KOBAYASHI, M. Ubiquity of borate-rhamnogalacturonan II complex in the cell walls of higher plants. Plant Cell Physiology, v.37, n.5, p.636-640, 1996.

MATOH, T.; ISHIGAKI, K.-I.; KAORI, O. et al. Isolation e characterization of a boronpolyssaccharide complex from radish roots. Plant Cell Physiology, v.34, p.639$642,1993$.

MATOH, T.; ISHIGAKI, K.-I; MIZUTANI, M. et al. Boron nutrition of cultured tobacco BY-2 cells. I. Requirement for intracellular localization of boron and selection of cells that tolerant low level of boron. Plant Cell Physiology, v.33, p.1135-1141, 1992. 
MAZEAU, K.; PÉREZ, S. The preferred conformations of the four oligomeric fragments of rhamnogalacturonans II. Carbohydrate Research, v.311, p.203-217, 1998.

McNEIL, M.; DARVILL, A.G.; FRY, S.C. et al. Structure and function of the primary cell walls of plants. Annual Review of Biochemistry, v.53, p.652-683, 1984.

MENGEL, K; KIRKBY, E. A. Principles of plant nutrition. Bern: International Potash Institute, 1987. 655p.

MORAES, L.A.C.; MORAES, V.H.F.; MOREIRA, A. Relação entre a flexibilidade do caule de seringueira e a carência de boro. Pesquisa Agropecuária Brasileira, v.37, n.10, p.1431-1436, 2002.

MORAES-DALLAQUA, M.A.; BELTRATI, C.M.; RODRIGUES, J.D. Anatomia de ápices radiculares de feijão cv. carioca submetidos a níveis de boro em solução nutritiva. Scientia Agricola, v.57, n.3, p.425-430, 2000.

MOZAFAR, A. Role of boron in seed production. In: GUPTA, U.C. (Ed.). Boron and its role in crop production. Boca Raton: CRC Press, 1993. p.186-206.

MURALIDHARAN, E.M.; MASCARENHAS, A.F. In vitro plantlet formation by organogenesis in Eucalyptus camaldulensis and by somatic embryogenesis in Eucalyptus citriodora. Plant Cell Reports, v.6, p.256-259, 1987.

MURASHIGE, T.; SKOOG, F. A. Revised medium for rapid growth and bioassays with tobacco tissue cultures. Physiologia Plantarum, v.15, n.3, p.473-497, 1962.

NABLE, R.O. Mechanism of tolerance to boron toxicity in plants. In: MANN, E.C.; RERKASSEN, B. (Ed.). Boron deficiency wheat. Mexico: CIMMYT, 1988. p.98109. (Wheat Special Report, 11).

NABLE, R.O.; BANUElOS, G.S.; PAULL, J.G. Boron toxicity. Plant and Soil, v.193, p.181-198, 1997. 
NABLE, R.O.; PAUL, L, J.G.; CARTWRIGHT, B. Problems associated with the use of foliar analysis for diagnosing boron toxicity in barly. Plant and Soil, v.128, p.225 - 232, 1990.

NGUYEN, M.N.; LUKASZEWSKI, K.M.; BLEVINS, D.G. IAA oxidase activity in squash roots may be regulated by boron and manganese interaction. Plant Physiology, v.102, p.7-15, 1995.

OERTLI, J.J.; ROTH, J.A. Boron supply of sugar beet, cotton and soybean. Journal of Agronomy, v.61, p. 191-195, 1969.

PARR, A.J.; LONGHMAN, B.C. Boron and membrane function in plants. In: ROBB, D.A.; PIERPOINT, W.S. (Ed.). Metal and micronutrients: uptake and utilization by plants. New York: Academic Press, 1983. p.87-107.

PARROT, W.A.; DURHAN, R.E.; BAILEY, M.A. Somatic embryogenesis in legumes. In: BAJAJ, Y.P.S. (Ed.). Somatic embryogenesis and synthetic seed II. Berlin: Springer-Verlag, 1995. p.200-227. (Biotechnology in Agriculture and Forestry, 31).

PARROT, W.A.; MERKLE, S.A.; WILLIANS, E.G. Somatic embryogenesis: potencial for use in propagation and gene transfer systems. In: MURRAY, D.R. (Ed.). Advanced methods in plant breeding and biotechnology. Wallingford: CAB International, p. 158-200, 1991.

PASSOS, L. P. Métodos analíticos e laboratoriais em fisiologia vegetal. Coronel Pacheco: EMBRAPA, CNPGL, 1996. 223p.

PAULL, J.G.; LANGRIGDE, P.; McINTOSH, R.A. Location of genes controlling boron tolerance of wheat. In: INTERNATIONAL WHEAT GENETICS SYMPOSIUM, 8., Beijing, 1995. Proceedings. Beijing: China Agricultural Scientech Press, 1995. p.1065-1069. 
PILBEAN, D.J.; KIRKBY, E.A. The physiological role of boron in plants. Journal of Plant Nutrition, v. 6, n.7, p.563-582, 1983.

PIMENTEL GOMES, F. Curso de estatística experimental, 13 ed., Piracicaba: Nobel, 1990. $468 \mathrm{p}$.

PIOUS, E.; RAVINDRA, S. Cupuassu explants under diverse conditions of in vitro culture. Revista Brasileira de Fruticultura, v.24, n.3, p.604-607, 1997.

POOVAIAH, B.W. Role of calcium and calmadulin in plant growth and development. HortScience, v.30, p.347-352, 1985.

POOVAIAH, B.; REDDY, A.S.N. Calcium messenger system in plants. CRC in Plant Science, v.6, p. 70-72, 1987.

PORTER, J.R.; LAWLOR, D.W. Plant growth: interactions with nutrition and environment. Cambridge: University of Cambridge Press, 1991. 284 p.

RAM, S.; BIST, L.D.; SIROHI, S.C. Internal fruit necrosis of mango and control. Acta Horticulture, n.231, p. 805-813, 1989.

RAMALHO, J.C.; NUNES, M.A. Photosynthesis impairment in Coffea arabica due to calcium deficiency. Agronomia Lusitana, v.47, p.101-116, 1999.

RAMALHO, J.C.; REBELO, M.C. SANTOS, M.E. et al. Effects of calcium deficiency on Coffea arabica. Nutrient changes and correlation of calcium levels with some photosynthetic parameters. Plant and Soil, v. 172, p.87-96, 1995.

RAMÓN, A.M.; CARPENA, R.O; GÁRATE, A. The effects of short-term deficiency of boron on $\mathrm{K}, \mathrm{Ca}$ and $\mathrm{Mg}$ distribution in leaves and roots of tomato (Lycopersicon esculentum) plants. In: VAN BEUSICHEM, M.L. (Ed.). Plant nutrition physiology and applications. Dordrecht: Kluwer, 1990. p. 287-290. 
RAVEN, J.A. Short- and long- distance transport of boric acid in plants. New Phytologist, v. 84, p.231-249, 1980.

REDDY, A.S.N. Calcium: silver bullet in signaling. Plant Science, v.160, p.381-404, 2001.

REINERT, J. Morphogenese und ihre kontrolle na geweberkulturn aus karotten. Naturwissenchaften, v.45, p.344-345, 1958.

REINERT, J.; YEOMAN, M.M. Callus formation and anthocyanin production in cultures of Haploppapus gracilis. In: REINERT, J. YEOMAN, M.M. (Ed.). Plant cell and tissue culture. Berlin: Springer Verlag, 1982. p. 48-50.

RERKASEN, B.; LONERGAN, J.F. Boron deficiency in genotypes in warm, subtropical region. Agronomical Journal, v.86, p.887-890, 1994.

RERKASEM, B.; NETSANGTIP, R.; BELL, R.W. et al. Comparative species responses to boron on a Tupic Tropaqualf in Northern Thailand. Plant and Soil, v.106, p.15$21,1988$.

REY, H.; MROGINSKI, L.A.; FERNADEZ, A. Induccion in vitro de callos y raices en explantos de seis cultivares de mandioca (Manihot sculenta Crantz). Phyton, v.39, n.1, 161-170, 1980.

RIBAS, L.L.F. Morfogênese in vitro e micropropagação de Aspidosperma polyneuron Müll. Arg. (Peroba-Rosa). Maringá, 1999. 65p. Tese (Doutorado) - Universidade Federal do Paraná.

ROCHA FILHO, J.V.; HAAG, H.P.; OLIVEIRA, G.D. et al. Deficiência de macronutrientes, B e Fe em Eucalyptus urophylla. Anais da Escola Superior de Agricultura “Luiz de Queiróz”, v.36, n.1, p.139-151, 1978.

ROCHA FILHO, J.V.; HAAG, H.P.; OLIVEIRA, G.D. Influência do B no crescimento e na composição química do Eucalyptus grandis. Brasil Florestal, v.39, p.29-33, 1979. 
RÖMHELD, V.; MARSCHNER, H. Functions of micronutrients in plants. In: MORDVEDT, J.J.; COX, F.R.; SHUMAN, L.M. et al. (Ed.). Micronutrients in agriculture. 2 ed. Madison: SSSA, 1991. p. 297-328 (SSSA. Book Series, 4).

SÁ, M.E.L. de; CANÇADO, G.M.A.; SOUZA, C.M. Cultivo de plantas in vitro e suas aplicações. Informe Agropecuário, v. 21, n. 204, p. 116-123, 2000.

SAKAI, W.S. Simple method for differencial staining of parafilm embedded plant material using toluidine blue 01. Stain Technology, v.48, p.247-249, 1973.

SATTLER, R.S.; RUTISHAUSER, R. The fundamental relevance on morphology and morphogenesys to plant research. Annals of Botany, v. 80, p.571-582, 1997.

SCHUMANN, G.; RYSCHKA, U.; SCHULZE, J.; KLOCKE, E. Anatomy of somatic embryogenesis. In: BAJAJ, Y.P.S. (Ed.). Somatic embryogenesis and synthetic seed I. Berlin: Springer-Verlag, 1995. p.3-19.

SCOTT, E.G. Effect of supra-optimal boron levels on respiration and carbohydrate metabolism of Helianthus annus. Plant Physiology, n. 35, p.653-661, 1960.

SGARBI, F.; SILVEIRA, R.L.V.A.; TAKAHASHI, E.N. et al. Crescimento e produção de biomassa de clone de Eucalyptus grandis X Eucalyptus urophylla em condições de deficiência de macronutrientes, B e Zn. Scientia Florestalis, n.56, p.69-82, 1999.

SHAH, S.H.; WAINWRIGHT, S.J.; MERRETT, M.J. The interaction of sodium and proline accumulation in callus cultures of Medicago sativa L. New Phytology, v.116, p.37-45; 1990.

SHARMA, P.N.; RAMCHANDRA, T. Water relations and photosynthesis in mustard plants subject to boron deficiency. Indian Journal of Physiology, v.33, n.2, p. 50 54,1990 .

SHARP, W.R.; EVANS, D.A.; SONDAHL, M. Application of somatic embryogenesis to crop improvement. In: FUJIWARA, A. (Ed.). Plant tissue culture. Tokyo: Maruzen, 1982. p.759-762. 
SHELP, B.J. Boron mobility and nutrition in broccoli (Brassica oleraceae var. italica. Annals of Botany, v.61, p.83-91, 1993.

SHKOL'NIK, M.Y.; KRUPNIKAVO, T.A.; TIMOFEEVA, S.S. et al. Intensification of quinone formation from exogenous polyphenols by homogenates of the leaves of sunflower plants reared under conditions of boron deficiency. Fisiologia Rastarum, v.28, p.541-546, 1981.

SILVEIRA, R.L.V.; HIGASHI, E.N.; SGARBI, F.; MUNIZ, M.R.A. Seja o doutor do seu eucalipto. Arquivo do Agrônomo, n.12, p.32, 2001.

SILVEIRA, R.L.V.A. Crescimento e estado nutricional de Eucalyptus citriodora sob concentraçõess de B e sua relação com a agressividade de Botryosphaeria ribis. Piracicaba, 1996. 100p. Dissertação (Mestrado) - Escola Superior de Agricultura "Luiz de Queiroz", Universidade de São Paulo.

SILVEIRA, R.L.V.A.; GONÇALVES, A.N.; SILVEIRA, R.I. et al. Levantamento nutricional de florestas de Eucalyptus grandis da região de Itatinga-SP: 1macronutrientes. In: CONGRESSO BRASILEIRO DE CIENCIA DO SOLO, 25., Viçosa, 1995. Anais. Viçosa: Sociedade Brasileira de Ciências do Solo, 1995. p.896898.

SILVEIRA, R.L.V.A.; GONÇALVES, A.N.; SIVEIRA, R.I. et al. Levantamento nutricional de floresta de Eucalyptus grandis da região de Itatinga-SP. II. Micronutrientes. In: CONGRESSO BRASILEIRO DE CIÊNCIA DO SOLO, 25. Viçosa, 1995. Resumos expandidos. Viçosa: SBCS; UFV, 1995. p.899-901.

SIMOLA, L.K. Propagation of plantets from leaf callus of Betula pendula f. purpurea. Scientia Horticulturae, v.26, p.77-85, 1985.

SKOK, J. The substitution of complexing substances for boron in plant growth. Plant Physiology, v.32, p.308-312, 1957. 
SLOCUM, R.D.; ROUX, S.J. Cellular and subcellular localization of calcium in gravistimulated coleoptiles and its possible significance in establishment of tropic curvature. Planta, v. 157, p. 481-192, 1983.

SMIRNOV, Y.S.; KRUPNIKOVA, T.A.; SHKOL' NIK, M.Y. Content of AIA in plants with diffrent sensivity to boron deficits. Soviet Plant Physiology, n.24, p.270-276, 1977.

SOTIROPOULOS, T. E.; THERIOS, I.N.; DIMASSI, K.N. Calcium application as a means to improve tolerance of kiwifruit (Actinidia deliciosa L.) to boron toxicity. Scientia Horticulture, v.81, p.443-449, 1999.

SPIEGEL-ROY, P.; VARDI, A. Citrus. In: AMMIRATO, P; EVANS, D.A.; SHARP, W.R. et al. (Ed.). Handbook of plant cell culture: crop science. New York: Mac Millan, 1984. v.3, p.355-372.

SPURR, A. R. The effect of boron on cell walls structure in celery. American Journal of Botany, v.44, p.637-650, 1957.

STAFFORD, A.; WAREN, G. Plant cell and tissue culture: the biotechnology series. Boca Raton: University Press, 1991. 251p.

STAPE, J.L. Potência de crescimento de Eucalyptus grandis numa areia quartzosa do estado de São Paulo. In: REUNIAO BRASILEIRA DE FERTILIDADE DO SOLO E NUTRICAO DE PlANTAS, 20., Piracicaba, 1992. Anais. Piracicaba: SBCS, 1992. p.172-173.

STEFANUTO,V.A. Efeito do cálcio no homeostase de brotações de um clone de Eucalyptus grandis Hill (ex Maiden) sob condições de deficiência hídrica induzida in vitro. Piracicaba, 2002. 65p. Dissertação (Mestrado) - Escola Superior de Agricultura Luiz de Queiroz, Universidade de São Paulo. 
STEWARD, F.C.; MAPES, M.O.; MEARS, K. Growth and organized development of cultured cells. II. Organization in cultures from freely suspended cells. American Journal of Botany, v.45, p.705-708, 1958.

STEINER, N.; VIEIRA, F.D.; GUERRA, M.P. Características histológicas e histoquímicas do desenvolvimento de embriões zigóticos e somáticos de Araucaria angustifolia. In: CONGRESSO NACIONAL DE BOTÂNICA. $3^{\mathrm{a}}$ REUNIÃO AMAZÔNICA DE BOTÂNICA, 54., Belém. 2003. Resumos. Belém: Universidade da Amazônia; UNAMA, 2003. p.15.

STEWART, C.R.; MORRIS, C.J.; THOMPSOM, J.F. Changes in aminoacid content of excised leaves during incubation II. Role of sugar in the accumulation in wilted barley leaves. Plant Physiology, v. 41, p.1585-1590, 1966.

STEWART, C.R. Role of carbohydrates in proline accumulation in wilted barley leaves. Plant Physiology, v.61, p. 775-778, 1978.

STOREY, R.; GORHAM, J.; PITMAN, M.G. et al. Response of Melantera biflora to salinity and water stress. Journal of Experimental Botany, v.44, p.1551-1560, 1993.

SOUZA, G.M.; GONÇALVES, A.N; ALMEIDA, M. Water deficit relation to leaf and stem anatomy of Eucalyptus camaldulensis Dehn. shoots cultivated in vitro. Scientia Agricola, v.56, n.3, p.723-731, 1999.

SUBBAIAH, M.M.; MINOCHA, S.C. Shoot regeneration from stem and leaf callus of Eucalyptus tereticornis. Plant Cell Reports, v.9, p.370-373, 1990.

TAIZ, L.; ZEIGER, E. Plant physiology. 2.ed. Saunderland: Sinauer Associates, 1998. $792 p$.

TAKEDA, T.; KITAGAWA, T.; TAKEUCHI, Y. et al. Metabolic responses of plant cell culture to hydrodynamic stress. Canadian Journal of Chemical Engineering, v.76, n.4, p.267-275, 1998. 
TANAKA, H. Boron absortion by crop plants as affected by other nutrients of the medium. Soil Science and Plant Nutrition, v.13, p.41-44, 1967.

TANADA, T. Localization of boron in membranes. Journal of Plant Nutrition, v.6, p.743-749, 1983.

TANADA, T. Boron as a transducer in some physiological process of plants. Journal of Plant Nutrition, v. 18, p. 1743-1750, 1995.

TEASDALE, R.D.; RICHARDS, D.K. Boron deficiency in cultured line cells. Quantitative studies of interaction with $\mathrm{Ca}$ and Mg. Plant Physiology, v.93, p.1071- 1077, 1990.

THOMPSON, M.R.; THORPE, T.A. Metabolic and non-metabolic roles of carbohydrates. In: BONGA, J.M.; DURZAN, D.J. Cell and tissue culture in forestry: general principles and biotechnology. Dordrecht: Martinus Nijhoff, 1987. v.1, cap. 6 , p. 89-112.

THORPE, T.A. Morphogenesis and regeneration in tissue culture. In: OWENS, L.D. (Ed.). Genetic engineering: aplications to agriculture. London: Rowman \& Allanheld, 1983. p.285-302.

THORPE, T.A.; PATEL, K.R. Clonal propagation: adventitious buds. In: VASIL, I. (Ed.). Cell culture and somatic cell genetics of plants: laboratory procedures and their applications. Orlando: Academic Press, 1984. v.1, cap.7, p.49-60.

TING, I.P. Plant physiology. Riverside: Addison-Wesley, University of California, 1982. 642p.

TOKESHI, F.; GUIMARAES, R.F.; TOMAZZELLO FILHO, M. Deficiência de B em Eucalyptus em São Paulo. Summa Phytopathologica, v.2, p.122-126, 1976. 
TORRES, A.C.; CALDAS, L.S.; FERREIRA, A.T. Retrospectiva da cultura de tecidos de plantas. In: TORRES, A.C.; CALDAS, L.S.; BUSO, J.A. (Ed.). Cultura de tecidos e transformação genética de plantas. Brasília: Embrapa - SPI; EmbrapaCNPH, 1998. v.1, p.87-132.

TREVIZAM, R. Atuação de concentrações de boro na morfogênese de Eucalyptus urophylla cultivados in vitro. Piracicaba, 2001, 65p. Dissertação (Mestrado) Escola Superior de Agricultura "Luiz de Queiroz", Universidade de São Paulo.

TREWAVAS, A.; KNIGHT, M. Mechanical signaling, calcium and plant form. Plant and Molecular Biology, v.26, p.1329-1341, 1994.

VAN DE VENTER, H.A.; CURRIER, H.B. The effect of boron deficiency on callose formation and $14 \mathrm{C}$ translocation in bean (Phaseolus vulgaris L.) and cotton (Gossipium hirsutum L.). American Journal of Botany, v.64, p.861-865, 1977.

VAN DER LINDER, P.C.G. Hormone action and sensitivity: possible relation to aging. In: RODRIGUES, R.; SANCHES, M.; TAMES, R.; DURZAN, D.J. (Ed). Plant aging: basic and applied approaches. New York: Plenun Press, 1990. p.285-292.

VAUGHAN, D; ORD, B.G. Influence of phenolic acids on morphological changes in roots of Pisum sativum. Journal of Science of Food and Agriculture, v. 52, p.289-299, 1990.

VEASEY, E.A.; VIEIRA, M.L.; BANDEL, G. Tissue culture in Gramineae, with emphasis on forage grasses. Ciência e Cultura, v.43, p.36-43, 1991.

VIEIRA, E. C.; GAZZINELLI, G.; MARES-GUIA, M. Bioquímica celular e biologia molecular. 2. ed. São Paulo: Atheneu, 1991. 360p.

VU, J.C.V.; NIEDZ, R.P.; YELENOVSKY, G. Glycerol stimulation of chlorophyll synthesis, embryogenesis and carboxylation and sucrose metabolism enzymes in nucellar callus of 'Hamlin' sweet orange. Plant Cell, Organ and Tissue Culture, v.33, p.75-80, 1993. 
WILlADINO, L.; CAMARA, T.; BOGET, N. et al. Polyamine and free amino acid variations in $\mathrm{NaCl}$-treated embryogenic maize callus from sensitive and tolerant cultivars. Journal of Plant Physiology, n.147, p.179-185, 1996.

WILLIAMS, E.G.; MAHESWARAN, G. Somatic embryogenesis: factors influencing coordinated behavior of cell as embryogenic group. Annals of Botany, v.57, p.443$462,1986$.

WILLIAMS, J.H.; GOSTICK, K. Water quality for crop irrigation: guidelines on chemical criteria. London: Ministry of Agriculture, Fish and Food, 1981. p.20.

WIMMER, M.A.; MÜHLING, K.H.; LÄUCHLI, A. et al. The interaction between salinity and boron toxicity affects the subcellular distribution of ions and proteins in wheat leaves. Plant, Cell and Environment, v.26, n.8, p. 1267, 2003.

YAMAUCHI, M. The role of B in higher plants: relationship between $\mathrm{B}$ and $\mathrm{Ca}$ on the pectin substances in plants. Journal of Soil Science, v.42, p.207-213, 1971.

YAMAUCHI, T.; HARA, T.; SONODA, Y. Distributions of calcium and boron in the pectin fraction of tomato leaf cell wall. Plant Cell Physiology, v.27, p.729 $732,1986$.

YENM, E.W.; WILLIS, A.J. The estimation of carbohydrates in plant extracts by anthrone. Biochemical Journal, v.57, p.508-515, 1954.

YEO, U.D.; KOHMURA, H.; NAKAGAWA, N.; SAKURAI, N. Quantitative and qualitative changes of cell wall polyssaccharides during embryogenesis and plantet development of asparagus (Asparagus officinalis L.) Plant Cell Physiology, v.39, n.6, p.607-614, 1998.

YEUNG, E.C. Structural and developmental patterns in somatic embryogenesis. In: THORP, T.A. (Ed.). In vitro embryogenesis in plants. Dordrecht: Klumer, 1995. p.205-247.

ZEKRI, M. PEG stress altered citrus root and leaf mineral concentrations. Journal of Plant Nutrition, v.18, n.6, p.1087-1102, 1995. 
ZIMMERMANN, J.L. Somatic embryogenes: a model for early development in higher plants. Plant Cell, v.5, p.1411-1423, 1993. 